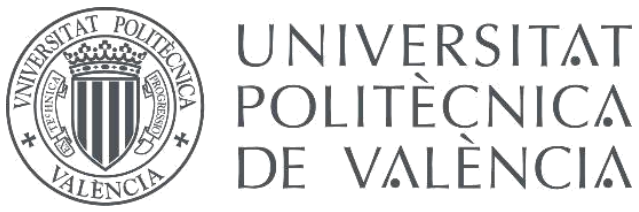

Department of Mechanical Engineering and Materials

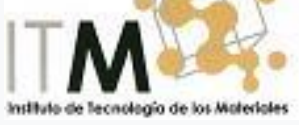

\title{
Development of new high-performance Titanium alloys with Fe-addition for dental implants
}

Doctoral Thesis

Prakash Mohan

Under guidance of:

Vicente Amigo Borras

Valencia, March 2020 

Memory presented by Prakash Mohan at the doctoral school of the polytechnic university of Valencia, doctoral program in engineering and industrial production, to qualify for the title of doctor.

This work has been developed in the department of material technology and mechanical and materials engineering department of Universitat Politecnica de Valencia, through the Spanish Ministry of Economy and Competitiveness under the Research Project PROMETEO 2016/040, MAT2018-53764-C3-1-R, and Erasmus-Mundus (Namaste) scholarship. 
Dedicated to my family 


\section{Acknowledgement:}

First, I want to thank Dr. Vicente Amigo Borras for all the knowledge and advice he has managed to convey to me and, above all, for his patience. He is always kind to me.

I want to express my gratitude to my family that always supports me unconditionally. They always supported me emotionally.

I also want to thank to scholarship program "Erasmus Mundus Action 2, Strand 1" (EMA 2) Namaste program and project 2018 from which they provide financially help during my research.

I also thank all the person who have supported me during my investigation, Angel, Paco, Montse, Esther, Jenny, Angelica, Juan carlos, Mauricio, Bakr, nelly, joan lario etc. I also want to thank all the lab assistant for helping me during my experiment.

There are many people who have influenced their bit in me and in this thesis during the time that I have been working on it. Thanks for everything. 





\section{Resumen:}

El titanio y sus aleaciones son los biomateriales principalmente usados debido a sus propiedades únicas como alta resistencia a la corrosión, bajo módulo de elasticidad, alta resistencia mecánica/densidad y buena biocompatibilidad. Las aleaciones Ti $\beta$ basadas en el sistema de aleación Ti-Mo muestran propiedades únicas para emplearse como biomateriales. Las aleaciones de Ti $\beta$ tienen un módulo de Young más bajo, menor apantallamiento de tensiones y menor reabsorción ósea. Esta investigación tiene como objetivo desarrollar un nuevo material biológico para un implante dental.

Esta investigación evalúa la adición de Zr y una pequeña cantidad de Fe sobre la estabilidad de fase $\beta$ y las propiedades mecánicas de la aleación de Ti-Mo que se utilizará para las aplicaciones médicas. Estas aleaciones se han producido utilizando dos técnicas de pulvimetalurgia (PM); La primera técnica es la combinación de polvos elementales (EB) que se ha seleccionado porque mejora el contacto superficial entre el elemento de aleación y el titanio (Ti) con una ruta rentable. El comportamiento de diferentes composiciones de aleaciones de Ti se evaluó utilizando esta técnica. Las muestras se prensaron uniaxialmente a $600 \mathrm{MPa}$ y se sinterizaron a $1250^{\circ} \mathrm{C}$. La segunda técnica evaluada en este estudio fue la aleación mecánica (MA). Esta técnica tiene una mayor energía de mezcla que la mezcla elemental, lo que mejora el contacto mecánico entre las diferentes partículas y ayuda a la difusión durante el proceso de sinterización. Las muestras se prensaron, igualmente, a $600 \mathrm{MPa}$ inicialmente, y después de evaluar las propiedades mecánicas, la presión de compactación se aumentó a 900 MPa para una mayor densidad en verde de los polvos.

Se realizaron diferentes pruebas mecánicas y estudios microestructurales para las muestras de mezcla elemental (EB) y las muestras de aleación mecánica (MA) para garantizar las propiedades adecuadas para aplicaciones biomédicas. Las diferentes 
pruebas para MA han sido la fluidez, adecuada para conocer el flujo del polvo después del ciclo de molienda, y el análisis granulométrico, adecuado para el análisis de la distribución del tamaño de los polvos. Otras pruebas comunes como la determinación de la densidad por el método de Arquímedes, adecuada para calcular la porosidad de las muestras sinterizadas, el ensayo de flexión a tres puntos para conocer las propiedades mecánicas de las muestras sinterizadas y conocer la energía conservada por las muestras a rotura, y la dureza Vickers de las aleaciones. Mediante ultrasonidos se ha determinado el módulo elástico de las aleaciones. El análisis microestructural se ha realizado mediante microscopía electrónica de barrido y análisis por energías dispersivas de rayos $\mathrm{X}$ mediante los que se ha determinado la homogeneidad química de las aleaciones. La difracción de electrones retrodispersados (EBSD) ha permitido obtener la orientación cristalina de cada grano y su tamaño, pues resulta una excelente herramienta para el microanálisis del material.

La densidad en verde para aleaciones de mezcla elemental está en el rango del 77.42$78.11 \%$ y para las muestras de aleación mecánica se han obtenido densidades relativas del 74.94-78.58\%. La densidad de los sinterizados, obtenida por el método de Arquímedes, está en el rango del 96.88-98.74\%, para la mezcla elemental de polvos. La resistencia a la flexión obtenida a partir de la prueba de flexión a tres puntos está en un amplio rango de 666 a $2161 \mathrm{GPa}$, mientras que para los polvos de aleación mecánica se encuentra en el rango de los 371 a 1597 GPa. El módulo elástico determinado en las aleaciones obtenidas con polvos de mezcla elemental está en el rango de los 95.5 a los $103 \mathrm{GPa}$, mientras que, en las obtenidas con los polvos mezclados mecánicamente, su módulo elástico oscila entre los 66 y los 82 $\mathrm{GPa}$, que sería más adecuado para un menor apantallamiento de tensiones. La microestructura de las muestras procesadas con polvos elementales con polvos mezclados mecánicamente, presentan diferencias sustanciales con un afinamiento del tamaño de grano con los polvos mezclados mecánicamente, aunque aparecen claramente diferenciadas dos fases distintas y una mayor proporción de fase $\alpha$. Debido a la menor densidad de las muestras procesadas con los polvos mezclados mecánicamente, estas presentan una menor resistencia mecánica y a su vez una menor plasticidad. Por ello se opta por utilizar técnicas de sinterización de alta densificación como el Spark Plasma Sinterirng (SPS) a pesar de lo cual no ii 
obtenemos mejora en el comportamiento mecánico de las mismas. Sin embargo, en los ensayos de corrosión y liberación de iones si se ha encontrado una sustancial mejor en las muestras obtenidas por SPS. 


\section{Resum:}

El titani i els seus aliatges són utilitzats, principalment, com a biomaterials per les seves propietats úniques com alta resistència a la corrosió, baix mòdul d'elasticitat, alta resistència mecànica específica $i$ bona biocompatibilitat. Els aliatges $\beta \mathrm{Ti}$ basades en el sistema d'aliatge Ti-Mo mostren propietats úniques per a emprar-se com biomaterials. Els aliatges de $\beta$ Ti tenen un mòdul de Young més baix, menor apantallament de tensions i menor reabsorció òssia. Aquesta investigació té com a objectiu desenvolupar un nou material biocompatible per a la seva aplicació com a implants dentals.

Aquesta investigació avalua l'addició de Zri petites quantitats de Fe sobre l'estabilitat de la fase $\beta$ i les propietats mecàniques dels aliatges Ti-Mo que s'utilitzaran per a aplicacions biomèdiques. Aquests aliatges s'han produït utilitzant dues tècniques pulvimetalúrgiques (PM); La primera tècnica és la mescla elemental de pols (EB) que s'ha seleccionat perquè millora el contacte superficial entre l'element d'aliatge $i$ el titani (Ti) amb una ruta rendible. El comportament de diferents composicions d'aliatges de Ti s'ha avaluat utilitzant aquesta tècnica. Les mostres es van premsar uniaxialment a $600 \mathrm{MPa}$ i es sinteritzaren a $1250^{\circ} \mathrm{C}$. La segona tècnica avaluada en aquest estudi va ser l'aliatge mecànica (MA). Aquesta tècnica té una major energia de mescla que la mescla elemental, el que millora el contacte mecànic entre les diferents partícules i ajuda a la difusió durant el procés de sinterització. Les mostres es van premsar a $600 \mathrm{MPa}$ inicialment, i després d'avaluar les propietats mecàniques, la pressió de compactació es va augmentar a $900 \mathrm{MPa}$ per a una major densitat en verd de les pols.

Es van realitzar diferents proves mecàniques i estudis microestructurals per a mostres de mescla elemental (EB) i per a mostres d'aliatge mecànica per garantir les propietats adequades per a aplicacions biomèdiques. Les diferents proves per MA són la prova de fluïdesa (adequada per conèixer el flux de la pols després del cicle d'aliatge mecànica) i l'anàlisi granulomètric (la prova és adequada per a l'anàlisi de distribució de la mida de les pols). S'han realitzat altres proves comunes com la prova d'Arquímedes, adequada per a calcular la porositat de les mostres sinteritzades. La 
prova de flexió de tres punts és adequada per conèixer la resistència a la flexió de les mostres sinteritzades i conèixer l'energia conservada per les mostres durant el seu trencament. Mitjançant ultrasons s'ha determinat el mòdul elàstic dels aliatges i la duresa s'ha realitzat per calcular la duresa Vickers de l'aliatge. S'ha realitzat l'anàlisi per SEM per conèixer la microestructura i l'anàlisi per EDX (mitjançant el qual es coneixeria la mescla adequada de l'element d'aliatge amb l'element central). EBSD (difracció d'electrons retro dispersats) també es realitza per a un més complet anàlisi sobre la microestructura, orientacions cristal-lines, mida de gra, mescla de diferents elements en els aliatges. EBSD és una excel-lent eina per al microanàlisi del material.

De la secció de resultats es determinen la densitat en verd de l'aliatge, fluïdesa de la pols mòlta, granulometria de la pols, densitat de l'aliatge sinteritzada (prova d'Arquímedes), resistència a la flexió i mòdul a flexió de l'aliatge, mòdul elàstic per ultrasons, microestructura de l'aliatge (per SEM i EBSD). La densitat en verd per als aliatges de mescla elemental està en el rang dels 77.42-78.11\%, mentre que per a les mostres d'aliatge mecànica van ser d'un 74.94-78.58\%. La densitat dels sinteritzats, obtinguda pel mètode d'Arquímedes, està en el rang dels $96.88-98.74 \%$, per la mescla elemental de pols. La resistència a la flexió obtinguda a partir de la prova de flexió de tres punts es troba en el rang dels 666-2161 MPa, mentre que per a les mostres de aliat mecànic el seu rang és molt ampli, des dels 371 als 1597 MPa. A partir de l'assaig d'ultrasons, el mòdul elàstic determinat per als aliatges de mescla elemental està en el rang de 95.5 a 103 GPa i per a les sinteritzades amb pols aliats mecànicament, es troba en el rang dels 66-82 GPa, que seria més adequat per a aplicacions biomèdiques. A partir de les anàlisis per SEM i EBSD, es confirma que l'aliatge mecànica és una mescla més homogènia en comparació amb la mescla elemental dels pols.

La densitat en verd (just després de la compactació) per a la mescla elemental és més gran que en l'aliatge mecànica, de manera que la densitat sinteritzada per a la mescla elemental és major igualment que en l'aliatge mecànica. A causa d'una major densitat dels sinteritzats, la porositat és menor en el cas de la mescla elemental. A més, a causa d'una major porositat, la resistència a la flexió és baixa en cas d'aliatge mecànica amb els mateixos paràmetres de sinterització que els aliatges de mescla elemental. El valor de microduresa és major en el cas de la mescla elemental en 
comparació amb l'aliatge mecànica. El mòdul elàstic també resulta més gran en el cas d'una mescla elemental comparat amb l'aliatge mecànica, que en aquest cas resultaria més adequat per a aplicacions biomèdiques. Els grans són més regulars $\mathrm{i}$ més petits en el cas de l'aliatge mecànica, a causa d'una distribució més homogènia dels elements en comparació amb la mescla elemental i als efectes de recristal-lització durant la sinterització.

L'aliatge mecànica va produir una mescla més homogènia dels elements d'aliatge, a causa de la mòlta a alta velocitat amb una relació boles/pols més alta que genera una major energia dins de les gerres i obté partícules de pols més petites. S'ha realitzat una combinació de diferents velocitats i temps de mòlta, optimitzant aquests paràmetres per a les nostres aliatges. 


\section{Abstract:}

Ti and its alloys are mostly used biomaterials due to its unique properties like (high corrosion resistance, low elastic modulus, high mechanical strength/ density and good biocompatibility). Ti $\beta$ alloys based on the Ti-Mo alloy system shows unique properties to employ as biomaterials. Ti $\beta$ alloys have lower Young Modulus, shielding stress and lower bone reabsorption. This research aims to develop a new biomaterial for a dental implant.

This research evaluates the addition of $\mathrm{Zr}$ and a small amount of $\mathrm{Fe}$ on the $\beta$-phase stability and the mechanical properties of Ti-Mo alloy to be employed for the medical applications. These alloys had been produced using two powder metallurgy (PM) techniques; first technique is elemental blending (EB) which had been selected because it enhanced the surface contact between the alloying element and Titanium (Ti) with a cost-effective route. The behavior of different Ti alloys composition was evaluated using this technique. Samples were uniaxial pressed at $600 \mathrm{MPa}$ and sintered at $1250^{\circ} \mathrm{C}$. Second technique evaluated in this study was Mechanical alloying (MA). This technique has higher mixing energy than elemental blend which improves mechanical contact between different particles, and it helps diffusion during the sintering process. Samples were pressed at $600 \mathrm{MPa}$ initially, and after evaluating mechanical properties, compaction pressure is changed to $900 \mathrm{MPa}$ for a high green density of powders.

Different mechanical tests and microstructural studies were performed for elemental blend (EB) samples and for mechanical alloying samples to ensure the properties suitable for biomedical applications. Different tests for MA are Fluidity test (suitable to know about the flow of the powder after milling cycle) and Granulometric Analysis (test is suitable for powder distribution analysis). Other tests are common like Archimedes test which is suitable for calculating the porosity of the sintered samples, Three-point bending test is suitable for knowing Bending strength of the sintered samples and to know energy conserved by the breaking samples, Ultrasonic 
test performed for knowing elastic modulus of the alloys, Hardness test performed for calculating the Vicker's hardness of the alloy, SEM analysis performed to know about microstructure and EDX analysis(by which proper mixing of the alloying element with the central element would be known). EBSD (Electron Beam Scattered Diffraction) is also performed for more analysis about microstructure, grain size, mixing of different elements in alloys. EBSD is an excellent tool for microanalysis of the material.

From the results section, Green density of the alloy, fluidity of the milled powder, Granulometry of the powder, sintered density of the alloy (From Archimedes test), bending strength and bending modulus of the alloy, Elastic modulus by Ultrasonic test, Microstructure of the alloy(By SEM and EBSD Analysis of the sintered part.) are determined. Green density for elemental blend alloys is in the range of (77.42$78.11 \%$ ) and for Mechanical alloying samples were (74.94-78.58\%). Sintered density obtained by Archimedes' test for the elemental blend is in the range of (96.8898.74\%). Bending strength obtained from three-point bending test is in range of (666-2161 MPa), and mechanical alloying is in range of (371-1597 MPa). From the high test, Determined Elastic modulus of the alloy is in range of (95.5-103 GPa) and for Mechanical Alloying elastic modulus was in the range of (66-82 GPa), which would be more suitable for biomedical applications. (From the SEM and EBSD analysis Mechanical alloying are more homogeneous mixing in comparison to Elemental Blend.

Green density (just after compaction) for the elemental blend is more than mechanical alloying so that Sintered Density for Elemental Blend is more than Mechanical Alloying. Due to higher sintered density, porosity is more in case of the elemental blend. Also, due to higher porosity, bending strength is low in case of mechanical alloying with same sintering parameters as Elemental blend alloys. Micro-Hardness value is more in case of elemental blend in comparison to Mechanical Alloying. Elastic modulus is more in case of elemental blend in comparison to mechanical alloying; lower elastic modulus is more suitable for biomedical applications. Grains are more regular and smaller in case of Mechanical alloying which is due to a more homogeneous distribution of the elements in comparison to elemental blend. 
Powder processing technique is changed from Elemental Blend to Mechanical Alloying due to the improvement of homogeneity of green powders. Mechanical Alloying produced more homogeneous mixture due to high-speed milling with higher Ball to powder ratio (which generates higher energy within the jars and breaks the powders into smaller particles). Different combination of milling speed and milling time performed for our results and the effects of a combination of different parameters observed. 


\section{Index}

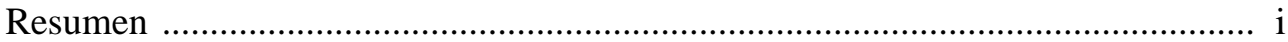

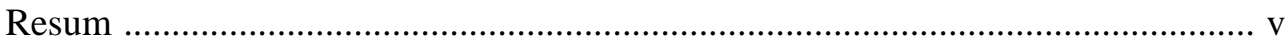

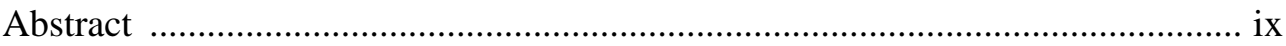

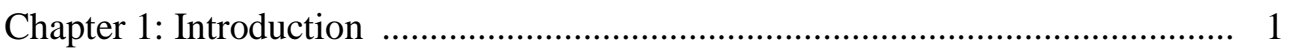

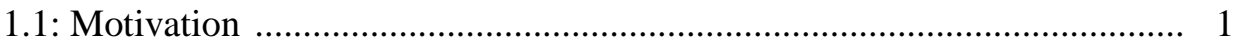

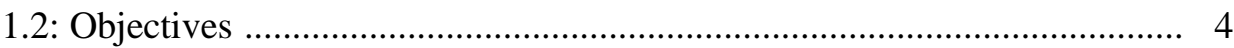

Chapter 2: State of the art ……………………............................................... 7

2.1 Metallic biomaterials ........................................................................... 7

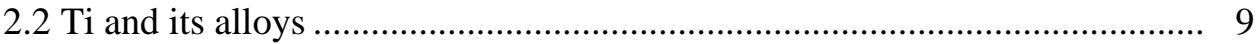

2.2.1 Low modulus Titanium alloys .......................................................... 10

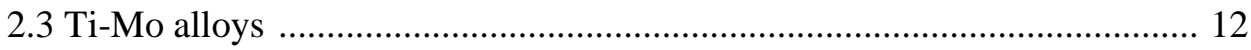

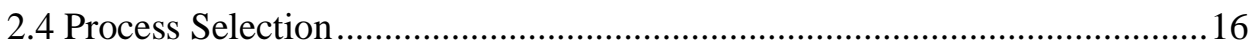

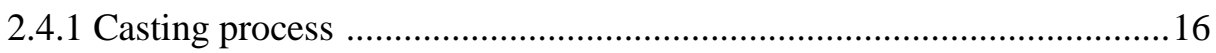

2.4.2 Powder metallurgy (P/M) Technology ……..........................................17

2.4.2.1 Elemental Blend (EB): .........................................................18

2.4.2.2 Mechanical alloying (MA) ...................................................... 19

2.4.2.3: Spark plasma sintering (SPS):...................................................24

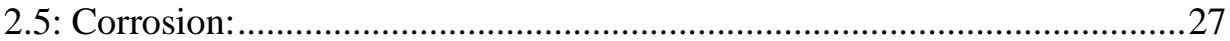

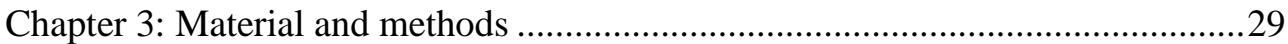

3.1: Phase 1: To see the effect of Mo and Fe on Ti-Mo alloy

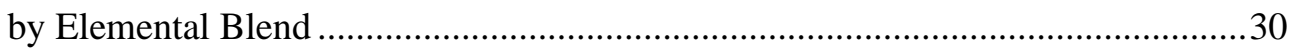

3.1.1: Task 1: Selection of elemental powders:.............................................. 31 


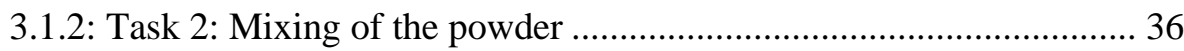

3.1.3: Task 3: Compaction of the mixed powder........................................ 38

3.1.4: Task 4: Sintering of the green sample .............................................. 39

3.1.5: Task 5: To know geometrical properties of the sintered samples like porosity by Archimedes' test ............................................................... 40

3.1.6: Task 6: Determination of Mechanical properties of the sintered part of samples: ...................................................................................... 41

3.1.7: Task 7: Microstructural characterization of the sintered part of the

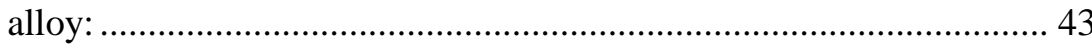

3.2: Phase 2: To perform mechanical alloying technique....................................... 49

3.2.1: Task 1: Mixing of powder without process control agent (PCA) ............ 49

3.2.2: Task 2: Mixing of powder with process control agent (PCA) ................. 53

3.3: Phase 3: for obtaining full density samples with spark plasma sintering Method............................................54

3.4: Phase 4: for obtaining $\mathrm{I}_{\text {corr }}$, open circuit potential (OCP), potential by

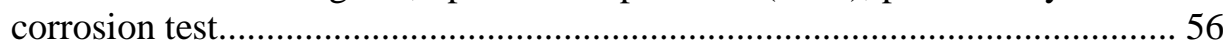

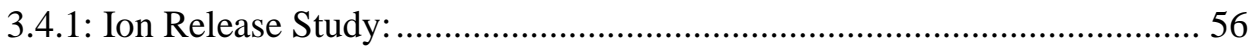

3.4.2: Study of resistance against corrosion …………..................................... 56

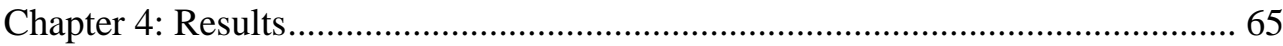

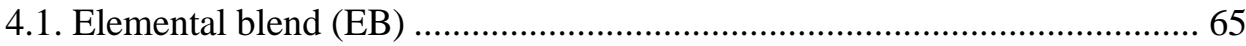

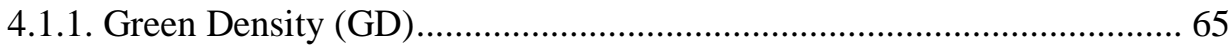

4.1.2. Porosity, Sintered Density and relative density:..................................... 66

4.1.3. Shrinkage calculation: .................................................................. 67

4.1.4. Bending strength (MPa), Tenacity $(\mathrm{J})$ and elongation (\%) of sintered

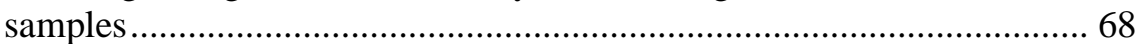

4.1.5. Elastic modulus EU (GPa), Eccentricity and hardness (HV) of sintered

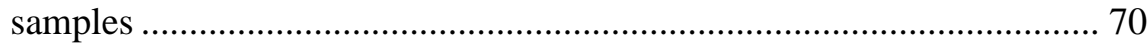




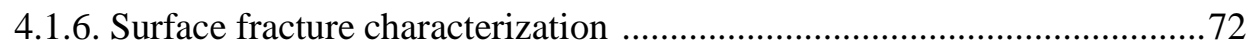

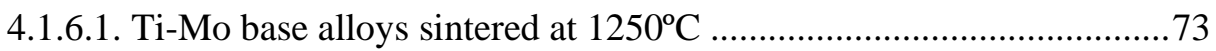

4.1.6.2. Fractography analysis of Ti-Mo-Zr-Fe quaternary alloys ..................73

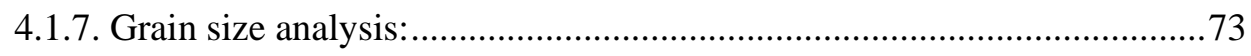

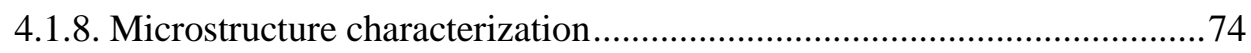

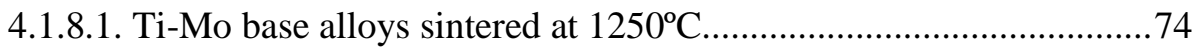

4.1.8.2. Microstructure analysis of Ti-Mo-Zr-Fe Quaternary

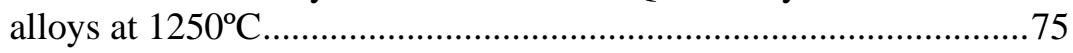

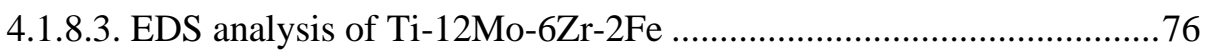

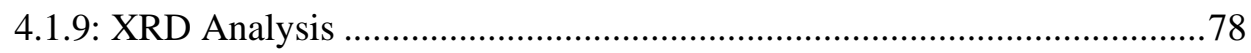

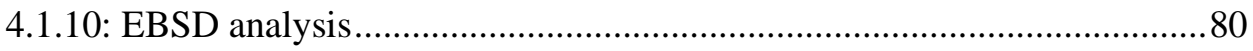

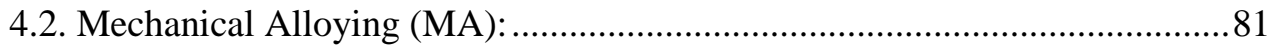

4.2.1: MA for Ti-12Mo-6Zr-2Fe with different compaction pressure ................81

4.2.1.1. Mechanical properties with short milling time...................................81

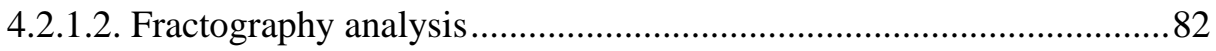

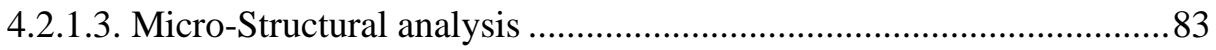

4.2.1.4. EBSD analysis of Ti-12Mo-6Zr-2Fe with MA at $900 \mathrm{MPa}$...............83

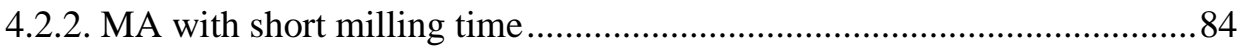

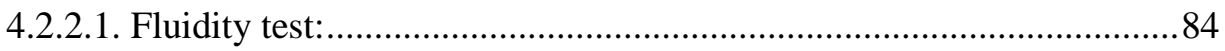

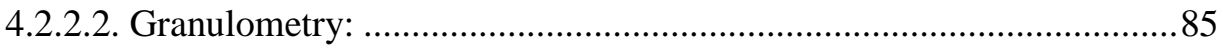

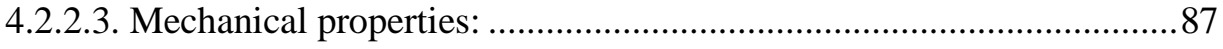

4.2.3: Mechanical alloying with 180 RPM-52 Min. for different alloys ............ 89

4.2.4: Mechanical alloying with Process control agent (PCA): ..........................90

4.3: Spark Plasma Sintering (SPS) Results: .....................................................93 


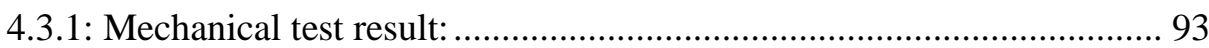

4.3.2: Micro hardness of Ti-Mo alloys with different conditions:.................. 94

4.3.3: DRX analysis of SPS samples with different conditions...................... 95

4.3.4: EBSD analysis of Ti-Mo alloys by SPS with different conditions....... 96

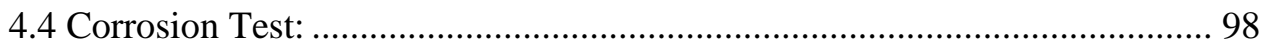

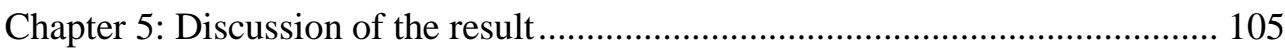

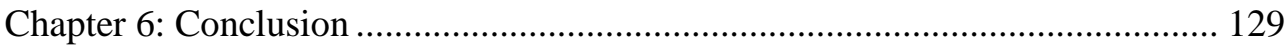

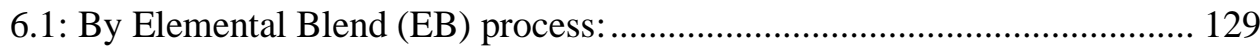

6.2: By Mechanical alloying (MA) process:................................................... 130

6.3: By Spark plasma sintering (SPS) process: ............................................. 131

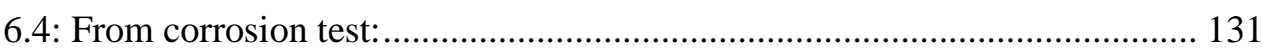

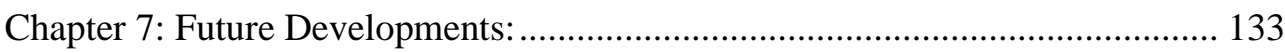

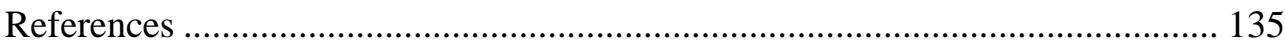

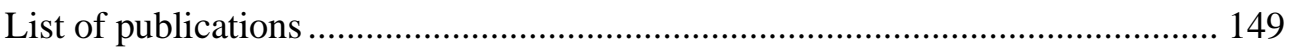




\section{List of Tables:}

Table 2.1 Mechanical properties of biomedical titanium alloys

Table 2.2 Different elastic modulus values of various medical titanium

materials

Table 2.3: Microhardness and bending properties of c.p. Ti and Ti alloys

fabricated 14

Table 2.4: Physical properties for elements used during our research .................. 15

Table 2.5: Important milestones in the development of mechanical alloying ........20

Table 3.1: Elemental powder with its suppliers and quality.....................................32

Table 3.2: Typical chemical analysis of supplier powder Ti, Mo and Fe ................34

Table 3.3: Granulometry of $\mathrm{Ti}, \mathrm{Mo}, \mathrm{ZrH}_{2}$ and $\mathrm{Fe}$ supplied powder.........................36

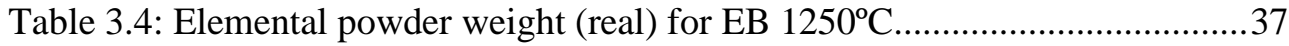

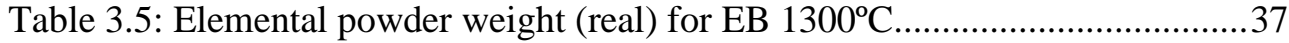

Table 3.6: Mechanical Alloying powder weight (real) with different parameters ..50

Table 3.7: Different combinations of milling time and milling speed with different

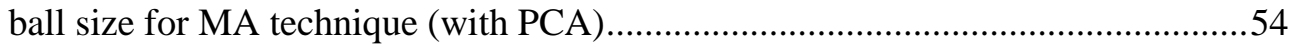

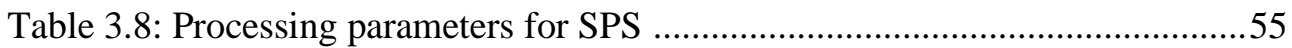

Table 3.9: Chi-square values obtained for the adjustment of the electric models of compact layer and double porous layer ...............................................................5

Table 3.10: Template to illustrate the calculation of the corrosion rate .................62

Table 3.11. Template to illustrate the calculation of polarization resistance ..........63

Table 4.1: Theoretical density, green density and relative green density of elemental blended samples.

Table 4.2: Theoretical density, close and open porosity, sintered density and relative green of elemental blended samples 
Table 4.3: Volumetric shrinkage (\%), Bulk shrinkage (\%) and linear shrinkage (\%) of elemental blended samples. 68

Table 4.4: Bending strength (MPa), Toughness (J) and Elongation (\%) of elemental

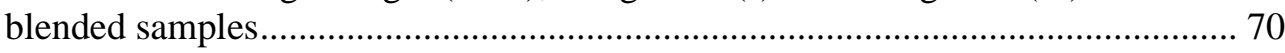

Table 4.5: Table 4.5: Elastic modulus (EU), Poisson's coefficient and Hardness of elemental blended samples. 71

Table 4.6: Grain Size Analysis of Ti-Mo alloy …………………….................... 74

Table 4.7: Elemental Composition calculated by smart map analysis.................... 75

Table 4.8: Elemental Composition calculated by smart map analysis of Ti-12Mo-

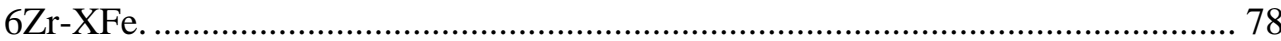

Table 4.9: Phase analysis by XRD analysis......................................................... 79

Table 4.10: Phase fraction for different alloys with EB ....................................... 81

Table 4.11 Relative density of Ti-12Mo-6Zr-2Fe with different conditions.......... 82

Table 4.12 Elastic modulus of Ti-12Mo-6Zr-2Fe with different conditions .......... 82

Table 4.13: Phase distribution and internal porosity ............................................. 83

Table 4.14: Phases analysis with EBSD for Ti-12Mo-6Zr-2Fe with MA at $900 \mathrm{MPa}$

Table 4.15: Fluidity (For Ti-15Mo and Ti-15Mo-6Zr-2Fe) with different milling

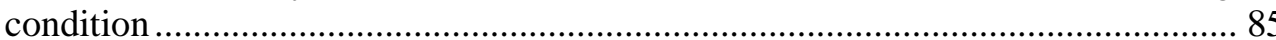

Table 4.16: Particle size analysis (For Ti-15Mo and Ti-15Mo-6Zr-2Fe) with

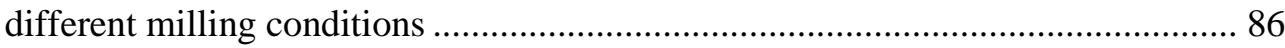

Table 4.17: Green density (\%), sintered density (\%) and bending strength of (For Ti-15Mo and Ti-15Mo-6Zr-2Fe) with different milling conditions.... 87

Table 4.18: Elastic modulus (GPa) (For Ti-15Mo) with different milling

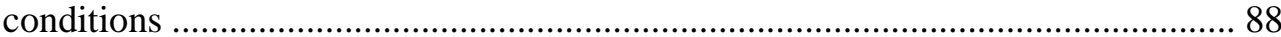

Table 4.19: Particle size analysis of Ti-Mo with 180 rpm-52 min ........................ 89

Table 4.20: green density, Sintered density and bending strength of Ti-Mo with

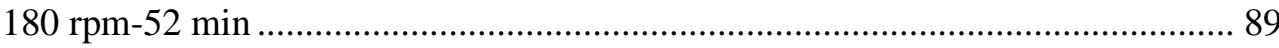

xviii 
Table 4.21: Elastic modulus of Ti-Mo with $180 \mathrm{rpm}-52 \mathrm{~min}$................................90

Table 4.22: Powder utility (\%) of Ti-15Mo-6Zr-2Fe with 1\% PCA …..................91

Table 4.23: Fluidity of Ti-15Mo-6Zr-2Fe with 1\% PCA .........................................91

Table 4.24: Particle size analysis of Ti15Mo6Zr2Fe with 1\% PCA .......................91

Table 4.25: Elemental analysis of Ti-15Mo-6Zr-2Fe with 1\% PCA by SEM

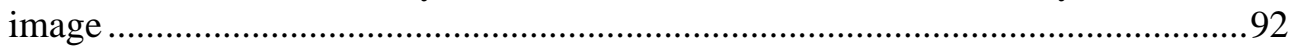

Table 4.26: Mechanical properties of sintered Ti-15Mo-6Zr-2Fe with $1 \%$ PCA by

SEM image.

Table 4.27: Different mechanical test of Ti-Mo alloys by SPS with different temperatures

Table 4.28: Micro hardness of Ti-Mo alloys by SPS with different temperatures.

Table 4.29: Phase analysis table of Ti-Mo alloys with different parameters

Table 4.30: Grain size with EBSD table of Ti-Mo alloys with different parameter.

Table 4.31: Corrosion result with different parameters $\mathrm{I}_{\text {corr }}\left(\mathrm{A} / \mathrm{cm}^{2}\right), \mathrm{E}_{\mathrm{corr}}(\mathrm{V})$,

$\beta_{\mathrm{c}}(\mathrm{V} / \mathrm{dec})$ and $\beta_{\mathrm{a}}(\mathrm{V} / \mathrm{dec})$ for different process .98

Table 4.32: Corrosion result with different parameters $\mathrm{OCP}(\mathrm{V}), \mathrm{R}_{\mathrm{p}}\left(\mathrm{K} \Omega . \mathrm{cm}^{2}\right)$ and $\mathrm{V}_{\text {corr }}(\mu \mathrm{m} / \mathrm{year})$ for different process. .99

Table 4.33: Ion-release rate of different particle with different parameters for corrosion. 102

Table 4.34: Corrosion velocity with ion-release rate .103 


\section{List of figures:}

Figure 2.1 Comparison of Young's modulus of cortical bone, $\beta$ type Ti-13Nb$13 \mathrm{Zr}, \alpha+\beta$ type Ti-6Al-4V, 316L stainless steel and $\mathrm{Co}-\mathrm{Cr}-\mathrm{Mo}$ alloy for biomedical applications

Figure. 2.2: Phase stability index diagram based on Bo and Md parameters ....... 13

Figure. 2.3: Microstructure of the Ti-10Mo-5Fe for MA alloy (SEM) ............... 19

Figure 2.4: Typical current and potential applications of mechanically alloyed products

Figure: 2.5: An ON-OFF pulsed current path through the spark plasma sintering machine

Figure 3.1: Flow diagram of overall project

Figure 3.2: Supplied powder of $\mathrm{Ti}, \mathrm{Mo}, \mathrm{ZrH} 2$ and $\mathrm{Fe}$ with different magnification.

Figure 3.3: Granulometric analysis of $\mathrm{Ti}, \mathrm{Mo}, \mathrm{ZrH} 2$ and $\mathrm{Fe}$ supplied powder ...... 35

Figure 3.4: (a) Press of compaction with the floating matrix between the compression plates, (b) detail of the cavity of the rectangular matrix of $12 \times 30 \mathrm{~mm}$ and (c) detail of the punch of the cylindrical matrix of $20 \mathrm{~mm}$ diameter

Figure 3.5: proposed sintering curve. Presents a heating $15^{\circ} \mathrm{C} / \mathrm{min}$ up to a temperature of $750^{\circ} \mathrm{C}$, idle time of $30 \mathrm{~min}$ to homogenise the temperature of the material and the oven, another cycle up to $1250^{\circ} \mathrm{C}$ and $10^{\circ} \mathrm{C} / \mathrm{min}, 3$ hours sintering and cooling in furnace 40

Figure 3.6: Micro hardness equipment Shimadzu HMV 2T ................................. 44

Figure 3.7: Fractured surface and after cut for microstructural analysis................ 45

Figure 3.8: (A) Optical microscopy equipment (NIKON elipse LV 100) (B) SEM

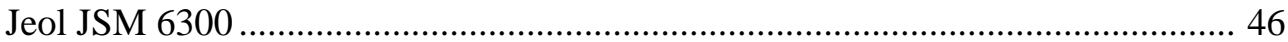

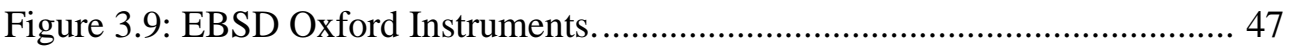

Figure 3.10: Bruker D2PHASER diffractometer. ................................................ 48

Figure 3.11: Glove box for mixing of powders for compaction............................. 51 
Figure 3.12: Planetary ball milling equipment (RETSCH PM 400/2)

Figure 3.13: Malvern instruments mastersizer 2000

dispersion unit AWM 2002.

Figure 3.14: (A) FAST HP D 5/1 equipment (model S8451) from FCT (B) Setup for sintering with charcoal disk (C) Sample during sintering..... 55

Figure 3.15: Scheme of the proposed routine for the study of resistance against corrosion

Figure 3.16. Scheme of a potentio-dynamic polarization curve 61

Figure 4.1: Fractography analysis of A) Ti-12Mo B) Ti-15Mo C) Ti-12Mo-6Zr

D) Ti-15Mo-6Zr with 500x magnification

Figure 4.2: Fractography analysis of (A) Ti-12Mo-6Zr-1Fe B) Ti-12Mo-6Zr-2Fe with magnification 250x and (C) Ti-12Mo-6Zr-3Fe (D) Ti-12Mo-6Zr-4Fe with 500x magnification

Figure 4.3: Microstructure of Ti-Mo base alloy with magnification 500X BS

(a) Ti-12Mo (b)Ti-15Mo (c) Ti-12Mo-6Zr (d)Ti-15Mo-6Zr 75

Figure 4.4: Microstructure of Ti-Mo quaternary alloy with magnification 500X BS (A) Ti-12Mo-6Zr-1Fe (B) Ti-12Mo-6Zr-2Fe (C) Ti-12Mo-6Zr-3Fe (D) Ti-12Mo$6 \mathrm{Zr}-4 \mathrm{Fe}$ at $1250^{\circ} \mathrm{C}$ 76

Figure 4.5: Smart map analysis of Ti-12Mo-6Zr-2Fe with 500x BS (A) General mixing of the alloying element (B) map of Ti, Mo K , Zr L and Fe K elemental mixing and (C) Spectrum obtained with EDS analysis 77

Figure 4.6: Phase analysis by XRD analysis of Ti-Mo alloys 79

Figure 4.7: IPF X mixed image by EBSD analysis of (A) Ti-12Mo (B) Ti-12Mo$6 \mathrm{Zr}$ (C) $\mathrm{Ti}-12 \mathrm{Mo}-6 \mathrm{Zr}-3 \mathrm{Fe}$ at $1250^{\circ} \mathrm{C}$ (D) $\mathrm{Ti}-12 \mathrm{Mo}-6 \mathrm{Zr}-3 \mathrm{Fe}$ at $1300^{\circ} \mathrm{C}$ 80

Figure 4.8: Fractography image of Ti-12Mo-6Zr-2Fe (A) with MA method under $900 \mathrm{MPa}$ compaction pressure (B) with EB method under $600 \mathrm{MPa}$ compaction pressure

Figure 4.9: Microstruture of Ti-12Mo-6Zr-2Fe: Mechanical alloying method with (A) $600 \mathrm{MPa}$ compaction pressure (B) with $900 \mathrm{MPa}$ compaction pressure 83 xxii 
Figure 4.10: (A) IPF X color image and (B) phase color of Ti-12Mo-6Zr-2Fe with MA at $900 \mathrm{MPa}$.

Figure 4.11: Granulometry for Ti-15Mo and Ti-15Mo-6Zr-2Fe (MA, P \& S) .......87

Figure 4.12: Bending strength of Ti-15Mo with different combination of parameters

Figure 4.13: Figure 5.13: SEM analysis of mechanical alloying powder with

(a) $6 \mathrm{~h}-5 \mathrm{~mm}$ (b) $6 \mathrm{~h}-10 \mathrm{~mm}$ (c) $24 \mathrm{~h}-5 \mathrm{~mm}$ (d) $24 \mathrm{~h}-10 \mathrm{~mm}$

Figure 4.14: DRX analysis of Ti-Mo SPS samples with different Temperature (a) of Ti-15Mo-6Zr (b) Ti-15Mo-6Zr-2Fe .95

Figure 4.15: IPF $X$ analysis of SPS samples (A) Ti-15Mo with $1100^{\circ} \mathrm{C}(\mathrm{B}) \mathrm{Ti}-$ $15 \mathrm{Mo}-6 \mathrm{Zr}-2 \mathrm{Fe}$ with $1100^{\circ} \mathrm{C}$ (C) Ti-15Mo-6Zr-2Fe with $1200^{\circ} \mathrm{C}$.

Figure 4.16: Different graphs for corrosion results of MA samples (A) $\log (\mathrm{i})$ vs E for samples without PCA (B) E vs t for samples without PCA 100

Figure 4.17: Different graphs for corrosion results of MA samples (A) $\log (\mathrm{i})$ vs E for samples with PCA (B) E vs t for samples with PCA 101

Figure 5.1: Shrinkage of Ti-Mo alloy 106

Figure 5.2: (A) Relative sintered density of Ti-Mo alloy (B) Relative sintered density of Ti-Mo-Zr-xFe at different temperatures

Figure 5.3: (A) Bending strength of Ti-Mo alloy (B) Bending strength of Ti-Mo$\mathrm{Zr}-\mathrm{xFe}$ at different temperatures

Figure 5.4: (A) Elastic modulus of Ti-Mo alloy (B) Elastic modulus of Ti-Mo-Zr$\mathrm{xFe}$ at different temperatures 111

Figure 5.5 (A) Hardness of Ti-Mo alloy (B) Hardness of Ti-Mo-Zr-xFe at different temp. 112

Figure 5.6: (A) Elongation to fracture of Ti-Mo alloy (B) Elongation to fracture of Ti-Mo-Zr-xFe at different temperatures 114

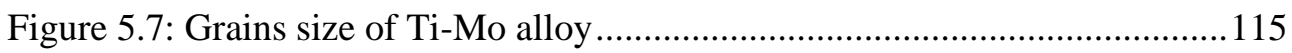

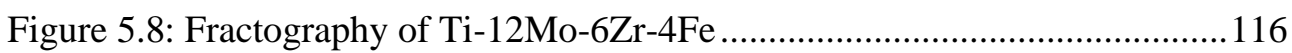


Figure 5.9: Euler color image of Ti12Mo (a) IPF X image of Ti12Mo (c) Phases image of Ti12Mo (d) Euler color image of Ti12Mo6Zr (e) IPF X image of Ti12Mo6Zr (f) Phases image of Ti12Mo6Zr.

Figure 5.10: IPFX colour image by EBSD analysis of Ti-12Mo-6Zr-3Fe at $1250^{\circ} \mathrm{C}$

Fig.5.11: Relative sintered density of SPS samples with different sintering samples

Fig.5.12: Bending strength of SPS samples with different sintering samples ..... 124

Fig.5.13: Elastic modulus of SPS samples with different sintering samples....... 125

Fig.5.14: Hardness of SPS samples with different sintering samples ................. 126

Fig.5.15: $\mathrm{E}_{\mathrm{Corr}}$ of $\mathrm{EB}$ samples with $1300^{\circ} \mathrm{C}$ sintering samples............................ 127 


\section{Abbreviations and Symbols:}

$\% \mathrm{~V}_{\mathrm{cl}}$ : Closed porosity

$\alpha$ : Hexagonal phase of Titanium

$\beta$ : Cubic phase of Titanium

$\gamma$ : Austenite phase of Titanium

$\alpha$ ': Alpha prime phase or martensite hexagonal of Titanium

$\alpha$ ": Alpha double prime phase or martensite orthorhombic of Titanium

$\varepsilon$ : Deformation

v: Poisson's coefficient

$\rho$ : Density

$\rho_{\mathrm{T}}$ : Theoretical density

$\rho_{\text {sint: }}$ Sintered density

$\mu \mathrm{m}:$ Micro-meter

$\mathrm{B}_{\mathrm{o}}$ : Bond order

b: width of the sample

$\beta_{\mathrm{a}}$ : Anodic slope of Tafel

$\beta_{c}$ : Cathodic slope of Tafel

$\mathrm{B}_{\mathrm{w}}$ real: Real ball weight

D: Dry mass of sample 
$\mathrm{d}$ : Thickness of the sample

D: Maximum deflection of the center of the sample

$E_{b}$ : Potential for breaking the passive layer

$\mathrm{E}_{\mathrm{v}}$ : Elastic modulus

F: Force applied on the sample

F: Faraday constant

$\mathrm{I}_{\text {corr: }}$ Corrosion current density

i: current density

$\mathrm{i}_{\mathrm{a}}:$ Partial anodic current density

$\mathrm{i}_{\mathrm{b}}$ : Partial cathodic current density

$\mathrm{i}_{\mathrm{p}}$ : Passivation current density

Hz: Hertz

kN: kilo Newton

L: Length of the sample

M: Mass of the sample in the air after eliminating excessive water

$\mathrm{M}_{\mathrm{d}}$ : Metal d-orbital energy level

P: \% open porosity

$\mathrm{P}_{\mathrm{w}}$ real: Real powder weight

$\mathrm{R}_{\mathrm{p}}$ : Passive layer resistance

$\mathrm{R}_{\mathrm{ct}}$ : Load transfer resistance

xxvi 
S: Mass immersed in water after saturation

t: Thickness of the sample

V: Volume

$\mathrm{V}_{\mathrm{cl}}$ : Closed pore volume

$\mathrm{V}_{\text {corr: }}$ Corrosion velocity

$\mathrm{V}_{\text {external: }}$ External volume

$\mathrm{V}_{\text {green: }}$ Green volume of sample

$\mathrm{V}_{\mathrm{L}}$ : Longitudinal velocity

$\mathrm{V}_{\mathrm{op}}$ : Open pore volume

$\mathrm{V}_{\text {sint: }}$ Sintered volume of sample

$\mathrm{V}_{\mathrm{T}}$ : Transversal velocity

$\mathrm{V}_{\text {Theoretical: }}$ Theoretical volume

$\mathrm{W}_{\text {sint }}$ : Sintered weight of sample

ASTM: American Society for Testing and Materials

BCC: Body centered Cubic

BPR: Ball to powder ratio

BS: Backscattered Electron detector

CP: Commercial pure

EB: Elemental blend

EBSD: Electron beam scattered diffraction 
EDS: Energy dispersive spectroscopy

EIS: Electrochemical impedance spectroscopy

HA: Hydroxy apatite

HCP: Hexagonal close packed

HIP: Hot isostatic pressing

IM: Ingot metallurgy

LSV: Linear sweep voltammetry

MA: Mechanical Alloying

MIM: Metal injection molding

MM: Mechanical mixing

OCP: Open circuit potential

ODS: Oxide dispersion-strengthened

OM: Optical microscopy

PAS: Plasma active sintering

PCA: Process control agent

P/M: Powder metallurgy

PVD: Physical vapor deposition

rpm: Revolution per minute

SEI: Secondary electron image

SEM: Scanning electron microscopy xxviii 
SiC: Silicon carbide

SPS: Spark plasma sintering

XRD: X-ray diffraction 




\section{Chapter 1: Introduction}

\section{1: Motivation}

It has been estimated that $90 \%$ of population over the age of 40 suffers from degenerative diseases and the aged people's population has increased tremendously in recent past and it is estimated there would be a seven times increase (from 4.9 million which was in 2002 to 39.7 million by 2010 (Jackson-Leach and Lobstein, 2006). Musculoskeletal disorders are most widespread human health problem which is costing around 254 billion dollars to the society (Ekpenyong, C.E., Udokang, N.E., Akpan, E.E., Samson, 2012).

Artificial biomaterials are the solutions for these problems, as surgical implantation of these artificial biomaterials of suitable shapes helps in restoring the function of the otherwise functionally compromised structures.

There is a tremendous increase in the demand for the new long-lasting implants, as the data collected on total joint replacements surgery by the end of 2030, the number of total hip replacements would rise by $174 \%$ (572,000 procedures) and total knee arthroplasties is projected to grow by $673 \%$ from the present rate $(3.48$ million procedures). The reason for joint replacements attributed to diseases such as osteoporosis (weakening of the bones), osteoarthritis (inflammation in the bone joints) and trauma. Replacement surgeries only have not been increased, simultaneously the revision surgery of hip and knee implants have also been increased (Kurtz et al., 2007).

The revision in surgeries which causes more pain for the patient is very expensive and the lesser success rate. The total number of hip revision surgery is expected to increase by $137 \%$ and knee revision surgery by $607 \%$ between the years 2005 and 2030 (Kurtz et al., 2007; Correa et al., 2018). Thus, a very high boom in implant manufacturing is expected in coming years. An ever-increasing demand for implants 
makes it imperative that development efforts on biomaterials have accelerated. The materials used for orthopedic implants especially for load-bearing applications should possess excellent biocompatibility, superior corrosion resistance in body environment, excellent combination of high strength and low modulus, high fatigue and wear resistance, high ductility and no cytotoxicity (Niinomi, 2002).

Metals and their alloys are widely used as biomedical materials. Ceramics or polymers cannot replace metallic biomaterials due to the inferiority of mechanical strength and toughness, which are most crucial safety requirements for biomaterials. Sometimes, metallic materials show toxicity and fracture because of their corrosion and mechanical damages (Hanawa, 2006) which is the ultimate reason for the trial of the new biomaterials. There is some specific purpose for development of novel Biomaterials. There should be some improvement which is necessary for biomaterials including toxicity elements elimination, decreased elastic modulus to avoid stress shield effect in bone fixation, enhanced biocompatibility.

Development of appropriate material with high longevity and excellent biocompatibility is highly essential. While several materials are currently in use as biomaterials, titanium alloys are fast emerging as the first choice for most applications.

So, development of new biomaterial is an exciting field of research in future due to its increasing demand, so the present research is carried out, and Ti $\beta$-alloy has better properties for this research.

The development of new alloy must be on a better balance between mechanical properties and microstructure of the resultant alloys. $\mathrm{Ti}$ and its alloys are most suitable alloys due to its superior comprehensive properties and satisfy the requirements of implantation materials better than other competing materials, such as stainless steels, Cr-Co alloys, CP niobium and Tantalum (Li et al., 2014).

The development of $\mathrm{Ti}$ and its alloys as implant material is perfectly reflecting the research goal of biomaterials. So, initially $\mathrm{CP} \mathrm{Ti}$ was proposed as an alternative for the 316L stainless steel and Co-Cr alloys (Li et al., 2014), which contains some harmful elements, such as $\mathrm{Ni}, \mathrm{Co}$ and $\mathrm{Cr}$. When there is need for high strength usage like hard tissue replacement or under intensive wear use, mechanical properties of 
CP Ti could not satisfy the requirement (Van Noort, 1987). For this reason, CP Ti replaced by $\alpha+\beta$ Ti alloys, particularly Ti-6Al-4V but Ti-6Al-4V is composed of cytotoxic elements like $\mathrm{Al}$ and $\mathrm{V}$, which may cause several problems once released into the human body (Alves et al., 2009). To overcome the potential V toxicity, $\mathrm{V}$ was replaced by $\mathrm{Nb}$ and $\mathrm{Fe}$, leading to two new $\mathrm{V}$ - free $\alpha+\beta$ Ti-based alloys, i.e., Ti$6 \mathrm{Al}-7 \mathrm{Nb}$ and Ti-5Al-2.5Fe (Fellah et al., 2015). Both alloys show better mechanical and metallurgical properties comparable to Ti-6Al-4V. Several studies confirmed that the elastic modulus of $\alpha$ and $\alpha+\beta$ alloys are much higher than that of human bone, which also causes stress shielding effect (Geetha et al., 2009)

In order to overcome these problems, low modulus $\beta$ type Ti based alloys have been developed on a bigger scale to alleviate stress shielding effect, among those representatives are Ti-15Mo, Ti-13Nb-13Zr, Ti-12Mo-6Zr-2Fe, Ti-35Nb-5Ta-7Zr and Ti-29Nb-13Ta-4.6Zr (Geetha et al., 2009; Drahansky et al., 2016; Lampman 2018).

Powder metallurgy technology (P/M) allows $\beta$ Titanium alloys to be produced with non-soluble phases, where the microstructure is achieved through solid-state diffusion. An elemental blended (EB) method is potentially the lowest-cost titanium components manufacturing process and Mechanical alloying (MA) is a P/M processing technique involving cold welding, fracturing and rewelding of powder particles in a high-energy ball mill, and has now become an established commercial technique to produce oxide dispersion strengthened (ODS) nickel- and iron-based materials.

Developing Ti- $\beta$ alloy started with Ti-Mo alloy having better mechanical properties and developing different Ti-Mo based alloy with different process techniques. Hence it is decided to develop this composition (Ti-Mo-Zr-Fe) with a different stoichiometric ratio like Ti-12Mo-6Zr-xFe (where $\mathrm{x}=1,2,3,4$ ) with two techniques of powder processing (Mechanical Alloying \& Elemental Blend), and this alloy is developed and found all the mechanical properties. Effect of sintering temperature $\left(1250^{\circ} \mathrm{C}\right.$ and $\left.1300^{\circ} \mathrm{C}\right)$ analyzed. There are some ideas for developing the better $\beta$ alloy. After successful development of these alloys, it is planned to work on Ti15Mo-6Zr-xFe (where $\mathrm{x}=2,3$ ) because Ti-15Mo gives better results than Ti-12Mo, 
and Ti-15Mo-6Zr also gives better mechanical properties than Ti12Mo6Zr. So, it is for a better implant alloy in the field of biomedical applications like dental purpose.

This Project mainly focuses on the development of an alloy which is suitable for Biomaterials. The requirements are low elastic modulus, higher bending strength, lower porosity, good surface, better corrosion resistance, Biocompatibility. Ti and its alloy are a promising candidate for this research. $\beta$ - Ti alloy is a suitable for dental implant due to its lower elastic modulus, excellent corrosion resistance and biocompatible. They are the most necessary properties of the biomaterial. So, it is decided to work with Ti-Mo alloy, due to Mo as it is a good $\beta$-stabilizer. Further developing of more ternary and quaternary alloy is feasible.

\section{2: Objectives:}

The main objective is Development of a new high-performance Titanium alloy (Mainly $\beta$-alloy) for dental implants and for this we are developing different specific objectives.

\section{Specific objectives:}

- Develop Ti-Mo binary, ternary alloys with addition of $\mathrm{Zr}$ and quaternary alloy with addition of different $(1,2,3,4) \%$ of Fe by weight by elemental blend (EB) and mechanical alloy (MA) powder processing technique.

- Determine the effects of compaction pressure (600 MPa and $900 \mathrm{MPa})$ on TMZF alloys with different powder processing Alloys.

- Sintering temperature has a more impact on the final mechanical, microstructure and corrosion properties of the alloy, so we also explore different sintering temperature for the alloy $\left(1250^{\circ} \mathrm{C}\right.$ and $\left.1300^{\circ} \mathrm{C}\right)$. The sintering temperature is the leading cause for better diffusion. So, if sintering temperature is proper, then diffusion is also proper. 
- Determine elastic modulus of the alloy with different techniques (like the addition of $\mathrm{Fe}$ reduces elastic modulus), higher porosity also has a lower elastic modulus, but this is not suitable for implants.

- For mechanical alloying (MA); Analyse the effect of milling speed and milling time for Ti-Mo alloy with MA technique. Also, choose one proper combination for work further.

- For MA technique; Study the effect of process control agent (PCA) with high-speed milling with different ball size ( $5 \mathrm{~mm}$ and $10 \mathrm{~mm}$ respectively).

- Improvement of mechanical properties with full density techniques like spark plasma sintering (SPS) technique.

- Analyse microstructure with one of best technique like SEM, XRD and EBSD. Analyse phase, grain boundary analysis of the alloys, mixing of the element inside the alloys after sintering processing.

- Corrosion resistant is a must characterization of the biomaterials, so we must determine $\mathrm{I}_{\text {corr }}\left[\mathrm{A} / \mathrm{cm}^{2}\right], \mathrm{E}_{\text {corr }}[\mathrm{V}]$, Open circuit potential $(\mathrm{OCP})[\mathrm{V}]$, Corrosion velocity $[\mu \mathrm{m} /$ year $]$, ion release rate $\left[\mu \mathrm{g} / \mathrm{L} \mathrm{cm}{ }^{2} \mathrm{~h}\right]$ of the sintered alloys. 
Development of new high-performance Titanium alloys with Fe-addition for dental implants

6 |Page 


\section{Chapter 2: State of the Art}

The present study focuses on developing new Ti $\beta$ alloys for biomedical application with powder metallurgy route and searching of metallic materials including Stainless steel alloys, Ti- alloys, Co-Cr alloys. Metallic implant materials, their usability and suitability for the present research is discussed.

\subsection{Metallic biomaterials}

Presently $70-80 \%$ biomaterials are mostly metallic implants; it's important for the reconstruction of the failed tissue especially for the reconstruction of the hard tissue failure. Presently world population is getting older at the earliest, and they need hard tissue implant for the long run. The metallic implant needs much improvement for the natural and mechanical biocompatibility. After all, bio-functionality of metallic biomaterials is at present inadequate and needs to improve a lot. Presently representative metallic biomaterials are stainless steel, Cobalt (Co)-Chromium (Cr), Titanium and its alloys. Within these available metallic biomaterials, Ti alloys show the highest biocompatibility, corrosion resistance and specific resistance (Ratio of the tensile strength to density), in comparison to stainless steel and $\mathrm{Co}-\mathrm{Cr}$ alloys. Among these metallic biomaterials, Co-Cr alloys exhibit the highest wear resistance and relatively higher strength compared with stainless steels and Ti alloys. Stainless steels generally exhibit higher ductility and cyclic twist strength compared with Co$\mathrm{Cr}$ and $\mathrm{Ti}$ alloys. Co-Cr has the highest stiffness than $\mathrm{Ti}$ alloys. Magnesium $(\mathrm{Mg})$ alloys, Iron (Fe), Tantalum (Ta) and Niobium (Nb) are also important. Highly intense research and development are being carried out globally on each type of metallic biomaterials which is tabulated in table 2.1 and shown in figure 2.1. The elemental components of metallic biomaterials are mainly non-toxic. Min representative elements are Ti, Ta, Nb, Molybdenum (Mo) and Zr. (Niinomi, Nakai and Hieda, 2012; Liu et al., 2014). 


\section{Development of new high-performance Titanium alloys with Fe-addition for dental implants}

Table 2.1 Mechanical properties of biomedical titanium alloys (Geetha et al., 2009)

\begin{tabular}{|c|c|c|c|c|}
\hline Material & Standard & $\begin{array}{l}\text { Modulus } \\
(\mathrm{GPa})\end{array}$ & $\begin{array}{c}\text { Tensile strength } \\
(\mathrm{MPa})\end{array}$ & $\begin{array}{l}\text { Alloy } \\
\text { type }\end{array}$ \\
\hline \multicolumn{5}{|c|}{ First generation biomaterials $(1950-1990)$} \\
\hline $\begin{array}{l}\text { Commercially } \\
\text { pure } \mathrm{Ti}(\mathrm{Cp} \\
\text { grade } 1-4)\end{array}$ & ASTM 1341 & 100 & $240-550$ & $\alpha$ \\
\hline $\begin{array}{c}\text { Ti-6Al-4V ELI } \\
\text { wrought }\end{array}$ & ASTM F136 & 110 & $860-965$ & $\alpha+\beta$ \\
\hline $\begin{array}{l}\text { Ti-6Al-4V ELI } \\
\text { Standard grade }\end{array}$ & $\begin{array}{l}\text { ASTM } \\
\text { F1472 }\end{array}$ & 112 & $895-930$ & $\alpha+\beta$ \\
\hline $\begin{array}{c}\text { Ti-6Al-7Nb } \\
\text { Wrought }\end{array}$ & $\begin{array}{l}\text { ASTM } \\
\text { F1295 }\end{array}$ & 110 & $900-1050$ & $\alpha+\beta$ \\
\hline $\mathrm{Ti}-5 \mathrm{Al}-2.5 \mathrm{Fe}$ & - & 110 & 1020 & $\alpha+\beta$ \\
\hline \multicolumn{5}{|c|}{ Second generation biomaterials (1990-till date) } \\
\hline $\begin{array}{c}\mathrm{Ti}-13 \mathrm{Nb}-13 \mathrm{Zr} \\
\text { Wrought }\end{array}$ & $\begin{array}{c}\text { ASTM } \\
\text { F1713 }\end{array}$ & $79-84$ & $973-1037$ & $\begin{array}{c}\text { Metastble } \\
\beta\end{array}$ \\
\hline $\begin{array}{c}\text { Ti-12Mo-6Zr- } \\
2 \mathrm{Fe}(\mathrm{TMZF})\end{array}$ & $\begin{array}{l}\text { ASTM } \\
\text { F1813 }\end{array}$ & $74-85$ & $1060-1100$ & $\beta$ \\
\hline $\begin{array}{c}\mathrm{Ti}-35 \mathrm{Nb}-7 \mathrm{Zr}- \\
5 \mathrm{Ta}(\mathrm{TNZT})\end{array}$ & - & 55 & 596 & $\beta$ \\
\hline $\begin{array}{c}\mathrm{Ti}-29 \mathrm{Nb}- \\
13 \mathrm{Ta}-4.6 \mathrm{Zr}\end{array}$ & - & 65 & 911 & $\beta$ \\
\hline $\begin{array}{c}\mathrm{Ti}-35 \mathrm{Nb}-5 \mathrm{Ta}- \\
7 \mathrm{Zr}-0.40 \\
(\mathrm{TNZTO})\end{array}$ & - & 66 & 1010 & $\beta$ \\
\hline $\begin{array}{c}\text { Ti-15Mo-5Zr- } \\
3 \mathrm{Al}\end{array}$ & - & 82 & - & $\beta$ \\
\hline Ti-Mo & $\begin{array}{l}\text { ASTM } \\
\text { F2066 }\end{array}$ & - & - & $\beta$ \\
\hline
\end{tabular}

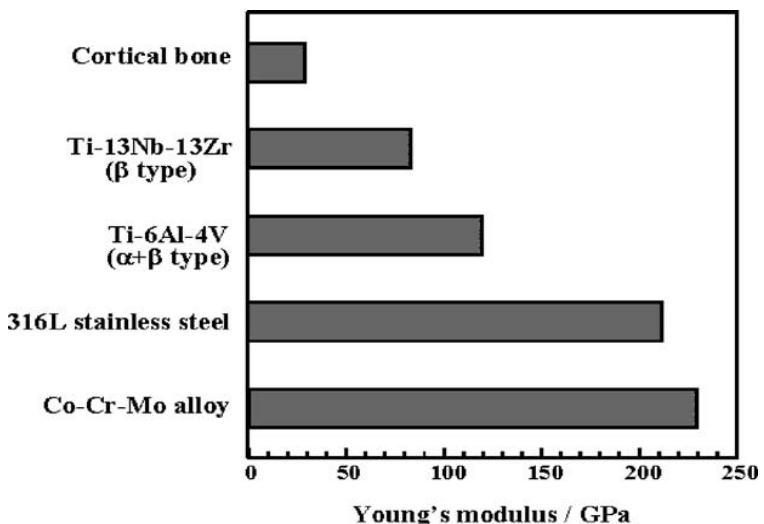

Figure 2.1 Comparison of Young's modulus of cortical bone, $\beta$ type Ti-13Nb-13Zr, $\alpha+\beta$ type Ti$6 \mathrm{Al}-4 \mathrm{~V}, 316 \mathrm{~L}$ stainless steel and $\mathrm{Co}-\mathrm{Cr}-\mathrm{Mo}$ alloy for biomedical applications (Niinomi, 2003b)

\section{8 |Page}




\subsection{Ti and its alloys}

Among all the available metallic biomaterials, Ti (pure Ti) and its alloys have the highest biocompatibility, corrosion resistance. Stainless steels and $\mathrm{Co}-\mathrm{Cr}$ alloys have inferior properties concerning Ti (pure Ti) and its alloy. (Niinomi, 2002; Zhao et al., 2012). Therefore, Ti and its alloy get attention by biomaterial scientists since last decade. Initially for the development of $\mathrm{V}$ free $\mathrm{Ti}$ alloys for biomedical applications, scientists developed Ti6Al7Nb and Ti5Al2.5Fe, because due to $\mathrm{V}$ present in Ti6Al4V ELI was toxic. After that Scientists started developing V and Al-free Ti alloys like Ti-Zr and Ti-Sn alloys which cause Alzheimer's disease due to A1 (still it is unclear). Nowadays stress shielding effect also got a lot of attention which are mostly metallic implants.(Niinomi, 2002). The leading cause of stress shielding is the mismatch or inhomogeneous transfer of stress between the implant and bone. Due to a much higher difference of Young's modulus of implants made of metallic implants and bones; stress predominantly transferred through the implant. It is the primary cause of bone absorption; it results in loosening of the implant or re-fracture of the bone after eliminating of the implant. For this reason, metallic implants with similar Young's modulus with bone, i.e., low modulus metallic implants are suitable for implant. Among the main metallic biomaterials, the modulus of Ti alloys is the smallest (Niinomi, 2002). From the figure 1, the elastic modulus of Ti alloy Ti6Al4V which is $(\alpha+\beta)$ alloy having modulus $110 \mathrm{GPa}$ and much lower than stainless steel and Co-based alloys (180 and $210 \mathrm{GPa}$, respectively). Ti alloys divided into three groups like $\alpha$-alloys, $(\alpha+\beta)$ type and $\beta$-type alloys. B-type Ti alloys have a lower modulus of elasticity than $\alpha$-alloys and $(\alpha+\beta)$ alloys. The main reason behind the difference between elastic modulus because of the crystal structure of the $\alpha$-phase, which is the primary component phase of $\alpha$-type Ti alloys, which is hexagonal closepacked (hcp), but for the $\beta$-phase, which is the primary component phase of $\beta$-type Ti alloys, is body centered cubic (bcc). All those above reasons, lowest modulus $\beta$ Ti alloys developing still is exciting research for biomaterial scientists. 
Development of new high-performance Titanium alloys with Fe-addition for dental implants

\subsubsection{Low modulus Titanium alloys}

Mainly alloys developed for biomedical applications are low modulus $\beta$-Ti alloys composed of non-toxic elements. Ti-13Nb-13Zr (Mishra et al., 1996) was the first low modulus $\beta$-type Ti alloys developed for biomedical applications. Then after developing different low modulus $\beta$-ti alloys like Ti-12Mo-6Zr-2Fe (TMZF) (I, I, and I 2017), Ti-15Mo (Zardiackas, Mitchell and Disegi, 2017), Ti-16Nb-10Hf (Wang, 1996) Ti-15Mo-5Zr-3Al, Ti35Nb7Zr5Ta (TNZT) (Kwasniak et al., 2014), and $\mathrm{Ti}-29 \mathrm{Nb}-13 \mathrm{Ta}-4.6 \mathrm{Zr}$ (TNTZ) (Niinomi, 2003a). After these alloys, a lot of low modulus $\beta$-type alloys developed or development in progress. Nowadays biomaterials scientists focused on Ti alloys which mainly contains low-cost elements such as $\mathrm{Fe}, \mathrm{Cr}, \mathrm{Mn}, \mathrm{Sn}$ and $\mathrm{Al}$ which might reduce consumption of high-cost factors such as the rare materials like $\mathrm{Nb}, \mathrm{Ta}$, Mo and $\mathrm{Zr}$. Some of the alloys with these elements are Ti-10Cr-Al (Hatanaka et al., 2010), Ti-Mn (Ikeda et al., 2009), Ti$\mathrm{Cr}-\mathrm{Al}$ (Sugano and Ikeda, 2005), Ti-Sn-Cr (Ashida, Kyogoku and Hosoda, 2012), Ti-(Cr, Mn)-Sn (Kusano et al., 2010), and Ti-12Cr (Nakai et al., 2011).

Now a days $\beta$-type Ti alloys containing $\mathrm{Nb}, \mathrm{Zr}$, Ta, Mo, $\mathrm{Sn}, \mathrm{Fe}$ etc., have attracted considerable attention mainly for orthopaedic implants' applications due to their unique combination of better mechanical properties like low elastic modulus, higher flexural strength, Superior biocorrosion resistance, allergy free implants, and superior biocompatibility. Some scientists also confirmed that elastic modulus of the alloy could significantly reduce by adjusting the concentration of $\beta$-stabilizing element. (Niinomi, 2002; Ikehata et al., 2004; Abdel-Hady, Hinoshita and Morinaga, 2006). New $\beta$-type Ti alloys mainly are made from the above elements, and they are non-allergic and non-toxic elements (Niinomi, 1998).

Depending upon its ability to achieve biological passivity and capacity of reducing the elastic modulus, the addition of $\beta$ stabilizing elements is preferred to produce safe Ti-based alloys for biomedical applications (Yang and Zhang, 2005).

Main features which should be in a metallic biomaterial is listed below.

1. Outstanding biocompatibility.

2. Better Osseo integration (bone ingrowth). 
3. Improved mechanical properties such as specific strength, fatigue resistance, impact strength, flexibility and low Young's modulus.

4. Superior corrosion behavior in body fluid.

5. Encouraging tribological characteristics, i.e., low friction and high wear resistance.

6. Long-term dimensional stability.

7. Processability (casting, plastic deformation, powder metallurgy, machinability, and welding).

All properties found in the alloys as mentioned earlier are mainly low elastic modulus $\beta$-Ti alloys.(Mohammed, 2014) .

Alloying elements for Ti alloys also play a vital role in properties of biomaterial which divides mainly into different categories like:

$\alpha$-stabilizers such as $\mathrm{Al}, \mathrm{O}, \mathrm{N}, \mathrm{C}$

$\beta$-stabilizers such as $\mathrm{V}, \mathrm{Nb}, \mathrm{Ta}, \mathrm{Mo}$ (isomorphous)

$\mathrm{Fe}, \mathrm{W}, \mathrm{Cr}, \mathrm{Ni}, \mathrm{Si}, \mathrm{Co}, \mathrm{Mn}, \mathrm{H}$ (Eutectoid)

Neutrals such as Zr and Sn.

The main mechanical properties of the biomaterial are elastic modulus. The lowest value from table 2.2 is for porous alloy Ti-19Nb-14Zr (14 GPa), which is like the modulus of cortical bone.

Ti alloy with different beta - stabilizing elements, and two alloying parameters was determined theoretically. First one is the bond order (denoted as $B_{o}$ ) which is a measure of the covalent bond strength between $\mathrm{Ti}$ and an alloying element. The second is the metal d-orbital energy level $\left(\mathrm{M}_{\mathrm{d}}\right)$ which correlates with the electronegativity and the metallic radius of elements. For alloys, the average values of $\mathrm{B}_{\mathrm{o}}$ and $\mathrm{M}_{\mathrm{d}}$ are defined by taking the compositional averages of the parameters and denote them $B_{o}$ and $M_{d}$, respectively. $B_{o}$ and $M_{d}$ values and the chemical compositions of the designed alloys in this study given in Table 2.2. Fig. 2.2 is a phase stability map (called the $B_{0}-M_{d}$ map)(Kuroda et al., 1998) in which the areas of $\alpha, \alpha+\beta$ and $\beta$ type alloys separated clearly. The stability region of the $\beta$ type alloys 
extends to the higher $B_{o}$ and the lower $M_{d}$ region. Positions of titanium and titanium alloys shown by the numbers surrounded by the open circles in Fig. 2.2. The values of moduli of elasticity also shown in parentheses. The benefits of moduli of flexibility for these alloys are decreased with increasing $B_{o}$ and $M_{d}$ values in $\beta$ type alloys region on the $B_{o}-M_{d}$ map. The alloy position moves in the $B_{o}-M_{d}$ map as the alloy composition varies as shown in Fig. 2.2.

Table 2.2 Different elastic modulus values of various medical titanium materials

\begin{tabular}{|c|c|c|c|}
\hline Alloy Designation & Type alloy & $\mathrm{E}(\mathrm{GPa})$ & Reference \\
\hline Ti19Nb14Zr(porous) & Near $\beta$ & 14 & (Ma, Cheng and Chung, 2013) \\
\hline $\begin{array}{l}\mathrm{Ti}-24 \mathrm{Nb}-4 \mathrm{Zr}- \\
\text { 7.9Sn(porous) }\end{array}$ & $\beta$ & 33 & (Hao et al., 2007) \\
\hline Ti-29Nb-6Ta-5Zr(porous) & $\beta$ & 43 & (Laheurte et al., 2010) \\
\hline Ti-35Nb-4Sn(porous) & $\beta$ & 44 & (Miura et al., 2011) \\
\hline $\mathrm{Ti} 25 \mathrm{Ta} 25 \mathrm{Nb}$ & $\beta$ & 55 & (Bertrand et al., 2010) \\
\hline Ti-10Zr-5Ta-5Nb & $\beta$ & 51.97 & (Raducanu et al., 2011) \\
\hline $\mathrm{Ti}-(18-20) \mathrm{Nb}-(5-6) \mathrm{Zr}$ & Near $\beta$ & $45-55$ & (Brailovski et al.,, 2011) \\
\hline Ti25Nb11Sn & Near $\beta$ & $45-55$ & (Miura et al.,, 2011) \\
\hline$T i-35 N b-7 Z r-5 T a$ & Near $\beta$ & 55 & (Oldani and Dominguez, 2007) \\
\hline $\mathrm{Ti}-35 \mathrm{Nb}-5.7 \mathrm{Ta}-7.2 \mathrm{Zr}$ & $\beta$ & 57 & $\begin{array}{c}\text { (Majumdar, Singh and Chakraborty, } \\
2008)\end{array}$ \\
\hline $\mathrm{Ti}-28 \mathrm{Nb}-13 \mathrm{Zr}-0.5 \mathrm{Fe}$ & Near $\beta$ & 58 & (Cui and Guo, 2009) \\
\hline Ti-29Nb-11Ta-5Zr & $\beta$ & 60 & (Laheurte et al.,, 2010) \\
\hline Ti-29Nb-13Ta-2Sn & $\beta$ & 62 & (Dalmau et al.,, 2015) \\
\hline Ti-12Mo-5Zr & $\beta$ & 64 & (Zhao, Zhang and Cao, 2011) \\
\hline Ti-29Nb-13Ta-4.6Zr & $\beta$ & 65 & (Tane et al., 2008) \\
\hline $\mathrm{Ti}-25 \mathrm{Nb}-2 \mathrm{Mo}-4 \mathrm{Sn}$ & Near $\beta$ & 65 & (Guo et al., 2013) \\
\hline TLM Alloy & $\beta$ & 67 & (Zhentao and Lian, 2006) \\
\hline Ti12Mo5Ta & Near $\beta$ & 74 & (Gordin et al., 2005) \\
\hline Ti-29Nb-13Ta-6Sn & $\beta$ & 74 & \\
\hline Ti-12Mo-6Zr-2Fe & $\beta$ & $74-85$ & (I, I and I, 2017) \\
\hline $\mathrm{Ti}-13 \mathrm{Nb}-13 \mathrm{Zr}$ & Near $\beta$ & 77 & $\begin{array}{l}\text { (Majumdar, Singh and Chakraborty, } \\
\text { 2008) }\end{array}$ \\
\hline Ti-15Mo & $\beta$ & 78 & (Sabeena et al., 2016) \\
\hline
\end{tabular}

\subsection{Ti-Mo alloys}

After analyzing and going through different literature review, we started working with Ti-Mo binary alloy, Ternary alloy and quaternary alloy. So, it is necessary to discuss Ti-Mo alloying system. Suitability of the $\beta$-Ti alloys depends on some factors like implant should have a less low elastic modulus, lower notch sensitivity 
and better biocompatibility than Ti-6Al-4V. As it discussed that Vanadium and $\mathrm{Al}$ were purposely avoided due to its toxic effect while the elements, i.e., $\mathrm{Mo}, \mathrm{Zr}$, and Fe introduced. The new titanium alloy, Ti-12Mo-6Zr-2Fe (TMZF), is unique in having a modulus of elasticity as low as $74 \mathrm{GPa}$, excellent mechanical strength and corrosion resistance coupled with reasonable wear and notch fatigue resistance.

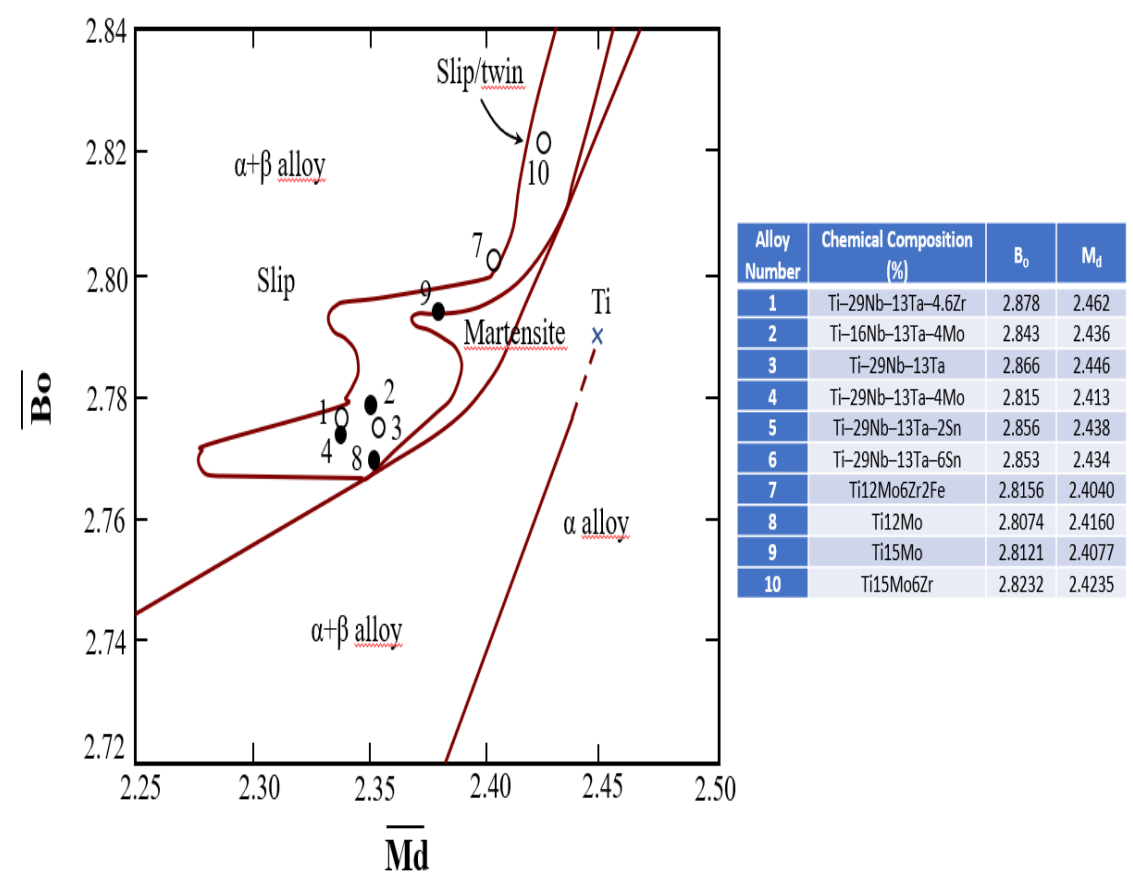

Figure 2.2: Phase stability index diagram based on $B$ o and $M$ d parameters. (Kuroda et al., 1998)

Molybdenum (Mo) is an isomorphous $\beta$ stabilizing element. For stabilizing $100 \% \beta$ retention at room temperature, a minimum of $10 \%$ Mo content needed in a Titanium plus Mo alloys. From the Ti-Mo equilibrium phase diagram indicates that $\alpha+\beta$ phase to $\beta$-phase transformation occurs at approximately $750^{\circ} \mathrm{C}$ for a binary composition containing $15 \%$ Mo. For a Ti-Mo system, for example, it moves to the left (the lower $\mathrm{M}_{\mathrm{d}}$ region) with increasing Mo content. (As we can see in fig 2.2), it is shown that Ti-12Mo have less $B_{o}$ values than Ti-15Mo. Ti $(12,15) \mathrm{Mo}$, Ti-(12,15)Mo-6Zr, Ti$(12,15)$ Mo-6Zr-xFe are the alloys which were used by our team for research. So, it's interesting to compare the results with each fusion. Such a vector varies in 
direction and magnitude, depending on alloying elements, as shown in the map. Once a specific $B_{0}-M_{d}$ region and an alloy system set in the plan, the similar alloy composition is determined merely following the rule of the vector sum. The trial and error experiments no longer needed to optimize the alloy composition.

From the figure 2.2, it clearly is shown that increase of $\%$ of Fe decreases the value of $B_{o}$ and decreases the amount of $M_{d}$. Addition of $Z r$ increases the value of $B_{o}$ and increases the value of $\mathrm{M}_{\mathrm{d}}$.

Different scientists (Ho, Ju and Chern Lin, 1999) worked with Ti-Mo binary alloys with different $\%$ of Mo $(6,7.5,9,10,12.5,15,17.5,20)$ by weight. The metastable $\beta$ phase Ti-15Mo alloy is being evaluated for orthopedic implant applications by Synthesis USA. The rapidly quenched Ti-15Mo alloy was reported to have $\alpha$ " grained bec structure with a lower modulus $(77.7 \mathrm{GPa})$ than that of $316 \mathrm{~L}$ stainless steel, Grade IV Ti, Ti-6Al-4V and Ti-6Al-7Nb (Zardiackas, Mitchell and Disegi, 1997).

Table 2.3: Microhardness and bending properties of CP Ti and Ti alloys fabricated (Zardiackas, Mitchell and Disegi, 1997)

\begin{tabular}{|c|c|c|c|}
\hline & Microhardness (HV) & Bending strength (MPa) & Bending modulus (GPa) \\
\hline CP Ti & 156 & 884 & 92 \\
\hline Ti6Al4V & 294 & 1857 & 105 \\
\hline Ti15Mo & 307 & 1348 & 71 \\
\hline Ti7.5Mo & 263 & 1395 & 55 \\
\hline
\end{tabular}


From the table 2.3, Ti-Mo alloys have less bending modulus than CP Ti, Ti-6Al-4V and higher bending strength than the CP Ti. Microhardness for Ti-Mo alloys are larger than CP Ti and like Ti-6Al-4V, which makes Ti-Mo alloys more suitable for biomaterials.

From the table 2.4, it clearly shown that melting point and density of Mo are the highest among all elements used during our research.

Table 2.4: Physical properties for elements used during our research (Li et al., 2015)

\begin{tabular}{|c|c|c|}
\hline Elements & Melting point $\left({ }^{\circ} \mathrm{C}\right)$ & Density $(\mathrm{g} / \mathrm{cc})$ \\
\hline $\mathrm{Ti}$ & 1668 & 4.506 \\
\hline $\mathrm{Mo}$ & 1538 & 10.28 \\
\hline $\mathrm{ZrH} 2$ & 800 & 5.6 \\
\hline $\mathrm{Fe}$ & 2623 & 7.87 \\
\hline
\end{tabular}

Molybdenum has strong $\beta$-stabilizing properties on titanium alloys, and small content should be enough to gain and stabilize a $\beta$-phasic titanium alloy. According to Eq. (2.1) (Park et al., 2017), the $\beta$-stabilizing effect of molybdenum can be obtained.

$$
\begin{aligned}
{[\mathrm{Mo}]_{\mathrm{eq}}=[\mathrm{Mo}]+} & \frac{1}{5}[\mathrm{Ta}]+\frac{1}{3.6}[\mathrm{Nb}]+\frac{1}{2.5}[\mathrm{~W}]+\frac{1}{1.5}[\mathrm{~V}]+1.25[\mathrm{Cr}] \\
& +1.25[\mathrm{Ni}]+1.7[\mathrm{Mn}]+1.7[\mathrm{Co}]+2.5[\mathrm{Fe}]
\end{aligned}
$$

In this equation, a large $\beta$-stabilizing character is recognized for eutectoid $\beta$ elements, such as $\mathrm{Fe}$. However, elements such as $\mathrm{Ta}$ or $\mathrm{Nb}$ have a stabilizing power of $\beta$-phase lower than Mo, so that a greater amount of these elements is used to obtain $\beta$-Ti alloys. The issue of elements biocompatibility becomes important upon choosing its composition. On the other hand, elements such as $\mathrm{Cr}, \mathrm{Mn}, \mathrm{Ni}, \mathrm{Co}$ and very less $\%$ of $\mathrm{Fe}$ may be useful to strongly improve the stabilizing character of the alloy (Geetha et al., 2009).

Ti-Mo alloys are one of most reliable alloys for bio-medical applications. There are lots of scientists who worked with Ti-Mo alloys like (Zhao, Zhang and Cao, 2011; Gao et al., 2012; Tsai et al., 2012; Zhang et al., 2015).

Density of Ti is $4.51 \mathrm{~g} / \mathrm{cm}^{3}$ (Correa et al., 2018) and addition of $\mathrm{Zr}$ and Mo increases the density of alloy whose density values are $\left(6.51 \mathrm{~g} / \mathrm{cm}^{3}\right)$ and $\left(10.22 \mathrm{~g} / \mathrm{cm}^{3}\right)($ Correa 
Development of new high-performance Titanium alloys with Fe-addition for dental implants

et al., 2018). Density is an important parameter for bio materials due to its need specific strength (mechanical strength to density ratio) (Mishnaevsky et al., 2014).

\subsection{Process Selection}

For dental implants or orthopedic implants, there are many conventional and advanced technologies available, including casting, milling, spark erosion, forging, powder metallurgy $(\mathrm{P} / \mathrm{M})$, and a combination of milling or spark erosion. From earlier studies and suitability for our research, work with powder metallurgy technology $(\mathrm{P} / \mathrm{M})$ is chosen. In $\mathrm{P} / \mathrm{M}$ technology, different powder processing technology like Elemental blend (EB), mechanical mixing without process control agent (PCA), mechanical mixture with process control agent (PCA) and Full density sintering like Spark Plasma Sintering (SPS) techniques are used. It started at EB and then proceed to other technology for overcoming the problems faced during our research. Casting also plays vital roles for the implant but using the process depends on its suitability, mechanical compatibility etc.,

\subsubsection{Casting process}

There are some unusual features associated with titanium casting. Unlike another metal casting, there are no commercial Ti alloys developed strictly for casting; therefore (i) Casting of all titanium alloys have compositions based on those of the standard wrought alloys and (ii) titanium castings are equal or nearly equal in strength to their wrought counterparts. The cast of titanium dental appliances noted by numerous studies in Japan, Europe, and the United States on the precision casting of dental prostheses, and the development of casting machines and suitable investment materials. The cast ability of Titanium and its alloys can be metallurgical improved (Yoda et al., 2001). For control, the casting defects especially with Titanium alloy (which cannot be $100 \%$ eliminated when using a casting process). The major flaws are shrinkage cavities, pinholes, or voids and these are all problems for denture bases. It's challenging to cast Titanium alloys, it's due to melting temperature difference between Titanium alloying element, reaction with oxygen, formation of $\alpha$-phase on the top layer of the alloys etc., Porosity is also a big problem for titanium casting, for example, some authors (Oshida, 2013) discussed that Ti6Al-4V have $(60.86 \%)$ cast ability and CP Ti have lower (48.44\%) cast ability. 
Powder metallurgy techniques would be the better option to improve the mechanical properties.

\subsubsection{Powder metallurgy (P/M) Technology}

The Powder Metallurgy (P/M) process is a near-net or net-shape manufacturing process that combines the features of shape-making technology for powder compaction with the development of final material and design properties (physical and mechanical) during subsequent densification or consolidation processes (e.g., sintering). It is critical to recognize this interrelationship at the outset of the design process because a subtle change in the manufacturing process can cause a remarkable difference in material properties. Titanium alloys' output improves day by day, but still, titanium alloys faced an issue of high-cost $\mathrm{P} / \mathrm{M}$ techniques have the advantages including elimination of the casting defects, less segregation and short process time. $\mathrm{P} / \mathrm{M}$ processing route also results in parts as close as Near Net shape (NNS) forming which reduces the overall cost of the parts.

Some P/M design found to be into considerations.

Size: For some powder processes, the product size is quite limited (such as metal injection molding, MIM), while for hot-isostatic pressing (HIP), extent not considered as a severe constraint.

Shape Complexity: It's easy to change the shape of the green part (Un-sintered) part of the alloy, it depends only on the die or mold shape.

Tolerances: Powder characteristics, compaction parameters and the sintering cycle are the main factors for determining the tolerances. In comparison to another process' parts like HIP parts, press and sintering P/M parts have very less amount of size change during sintering; it's the main reason of the products typically have the closest dimensional tolerances.

Material systems: powder shape, size and purity are also the primary factors during $\mathrm{P} / \mathrm{M}$ manufacturing process. For example, conventional press and sintering method required irregular powder shape and distribution of particle size for better green 
strength and sinter ability. Hot isostatic pressing needs spherical powders (gas atomized) for lowest impurities and good particle packing.

Properties: The physical and mechanical properties are primary characteristics of the functional response.

Quality and cost: The number of pieces produced is main factors of economic feasibility. For press and sintering, minimum 1000 to 10000 or even larger sections should produce for desired tooling investment.

The P/M manufacturing methods can divide into two main categories: conventional press-and-sinter methods and full-density processes.

Conventional press and sintering methods: This process includes compaction (compaction pressure depends on the dimensional usability and processing, sintering (according to requirement and alloying elements). Optional machining like grinding, cutting etc., could be performed with the sintered part.

For the present research, elemental blend and mechanical mixing or high energy ball milling process was used.

\subsubsection{Elemental Blend (EB):}

The elemental blend is a simple and cost-effective technique in which fewer powders are used for the part production. The main problem faced during EB techniques is lack of homogeneity and confirmed by microstructure.

Elemental blend technique is useful where cost is a significant constraint and number of parts would be more. But for costlier parts where surface quality and homogeneity of the alloy are the constraints then this technique is not very useful. High energy ball milling or mechanical mixing or mechanical alloying (MA) are used for the homogenized microstructure as shown in figure 2.3. 


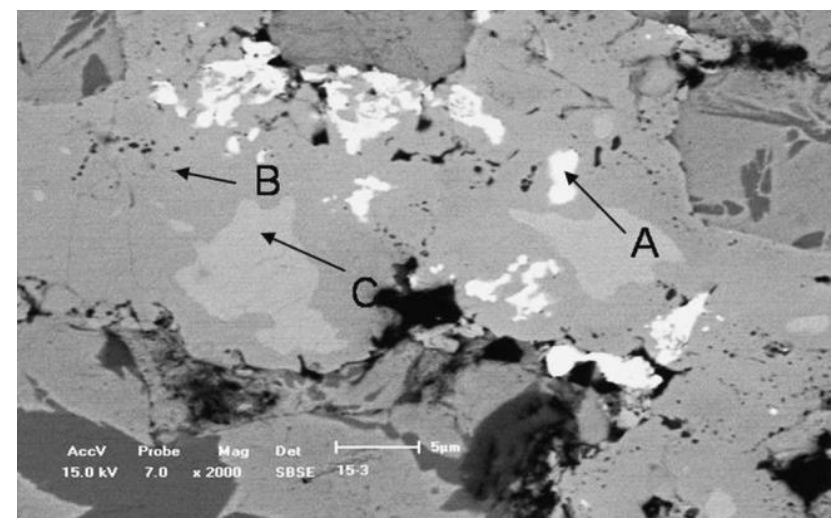

Figure 2.3: Microstructure of the Ti-10Mo-5Fe for MA alloy (SEM) (X. Li et al., 2015)

\subsubsection{Mechanical alloying (MA)}

Mechanical alloying (MA) is a $\mathrm{P} / \mathrm{M}$ processing technique involving cold welding, fracturing and re-welding of powder particles in a high energy ball mill (Suryanarayana, Ivanov and Boldyrev, 2001). MA is a dry powder processing technique which is employed to synthesize both equilibrium and metastable phases of commercially useful and scientifically useful materials. This technique was developed by Benjamin (Benjamin, 1976) around 1966 to form an alloy combining oxide dispersion strengthening with $\gamma^{\prime}$ precipitation hardening intended for gas turbine applications in a nickel-based superalloy as shown in table 2.5. Oxidedispersion could not be possible in the liquid phase so that solid-state processing technique is necessary; for this reason, MA is started using for industrial uses. The main advantage of using MA technique is that it produces different alloys, e.g. alloying of immiscible elements which are not possible with other technology.

The process of mechanical alloying consists of loading of powder mix and grinding mix (mainly of Co-Cr or tungsten carbide balls) in a stainless-steel container sealed under a protective Argon atmosphere (for avoiding/ minimizing oxidation and nitration during milling) and milling for the estimated length of the time. Approximately 1-2\% of process control agent (PCA) added during milling for protection of the cold welding. There is a different type of milling equipment like Spex mills, Fritsch mills or planetary ball mills. In case of planetary ball mills, 
control milling time and dwell time can be monitored after each small milling cycle and milling speed as shown in figure 2.4.

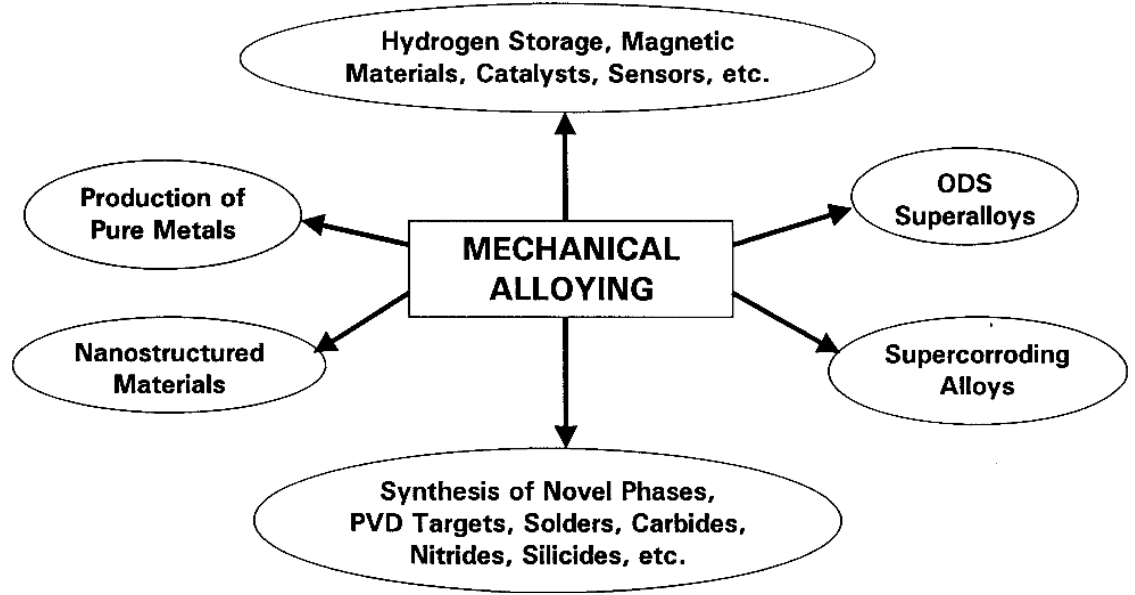

Figure 2.4: Typical current and potential applications of mechanically alloyed products (Suryanarayana, Ivanov and Boldyrev, 2001)

Agglomeration is also a phenomenon which is reported in mechanically alloyed powder mixtures. The phase has been obtained starting from elemental blend powders or mixtures of intermetallic (MA), or stoichiometric compounds (prealloyed intermetallic or even pure elements) (referred to as mechanical milling, MM)(Suryanarayana, Ivanov and Boldyrev, 2001).

Table 2.5: Important milestones in the development of mechanical alloying (Herr, 1995)

\begin{tabular}{|c|c|}
\hline 1966 & Development of ODS nickel-base alloys \\
\hline 1981 & Amorphization of intermetallics \\
\hline 1982 & Disordering of ordered compounds \\
\hline 1983 & Amorphization of blended elemental powder mixtures \\
\hline $1987 / 88$ & Synthesis of nanocrystalline phases \\
\hline 1989 & Occurrence of displacement reactions \\
\hline 1989 & Synthesis of quasicrystalline phases \\
\hline
\end{tabular}

In literature, there is mainly two ball mills powder processing with high energy discussed. Former is Mechanical alloying and latter is mechanical mixing. 
Mechanical alloying (MA) primarily deals with the process when powders of (different metals or alloys/compounds) are milled together. In this process, the main reason for homogeneity is material transfer. But for the latter, i.e., Mechanical mixing (MM) deals with the uniform milling (even stoichiometric) composition powders, such as pure metals, intermetallic, or pre-alloyed powders, where the material transfer does not require for homogeneity. The advantage of MM over MA is less process time for MM; it's due to alloyed MM powders and powders are just needed for particle reduction and other transformations need to be induced mechanically. For example, MM requires approximately half of the time in comparison to MA.

Mechanical Alloying process depends on a lot of factors which need optimization of the process variables for better microstructure, or for achieving the desired products. Mainly process variables affect the quality of powder, or final product are:

Type of mill: There are the different type of mills available in the market like mixer mills, planetary mills, attritors, Uni-ball mills etc., These mills differ in their Capacity, ability to Control the process and temperature inside jars etc.,

Milling container: The material used for milling container is essential due to the impact of grinding medium of the inner walls of the container. If the substance of the vessel is different from the powder used, some material might be dislodged and get incorporated into the powder. It might be contaminating the powder.

Milling speed: The usual concept is Milling energy $\boldsymbol{\alpha}$ Milling speed i.e. if the milling speed is high, milling energy is also high and vice versa. But milling speed depends on the design of the mill. Above a certain speed (Critical Speed) balls might be pinned to the inner walls of the vials. More speed also generates high heat inside the Jar. In some cases, it might be useful like where diffusion is required to promote homogenization or alloying in the powders. But in some cases, increased temperatures accelerate the process a lot and change the phases.

Milling time: This is the most critical parameter. Mainly the time is so chosen as to achieve a steady state between the fracturing and cold working of the powder 
particles. It depends on the type of mills used, the intensity of milling, ball to powder ratio (BPR) and temperature of milling.

Type, size, and size distribution of the grinding medium: Hardened steel, hardened Chromium steel, tool steel, WC-Co and bearing steel are the mainly used materials for the abrasive medium. The density of the abrasive medium should be high enough so that balls can create enough impact force onto the powder. The size of the grinding medium also plays a vital role in the milling efficiency. In general, a significant proportion (high density) grinding balls is more useful because it can transfer more impact energy onto the powder particles.

Ball-to-powder (BPR) weight ratio: It is an essential variable in the milling process. It might be from 1:1 to 220:1 depends on the investigators. Usually 10:1 is used for small mills but for large mills BPR should be 50:1 to 100:1. Higher the BPR, shorter the milling time required. For the present study, BPR would be 10:1 to 15:1.

The extent of filling the vial: Alloying among the powder particles mainly occurs due to the impact forces applied on them, so it is necessary that there should be enough space for the balls and the powder particles to move freely around in the container. Usually, 50\% of the Vial space is left empty in most of the milling. For our research, vial approximately is filled with one-third.

Milling atmosphere: The main effect of the milling atmosphere is for the contamination of the powder. For this reason, the powders milled in those containers which have been either evacuated or filled with an inert gas such as Argon (Ar) or Helium (He). In the present study, jars filled with Argon for avoiding contamination.

Process control agent (PCA): A process control agent (PCA) is added to the powder mixtures during milling to reduce the effect of cold welding. It may be solid, liquid or gases. The stearic acid used as PCA.

All the above variables are not independent, like milling speed and milling time depends on the type of mill. 
Few reported that any alloy could be made amorphous under the appropriate milling conditions. Amorphous phases form from EB powders either directly or via the formation of an intermetallic phase.

For example:

$\mathrm{mA}+\mathrm{nB} \longrightarrow\left(\mathrm{A}_{\mathrm{m}} \mathrm{B}_{\mathrm{n}}\right)$ amorphous

or $\mathrm{mA}+\mathrm{nB} \longrightarrow\left(\mathrm{A}_{\mathrm{m}} \mathrm{B}_{\mathrm{n}}\right)$ crystalline $\longrightarrow\left(\mathrm{A}_{\mathrm{m}} \mathrm{B}_{\mathrm{n}}\right)$ amorphous

In some other instances, it may be like,

EB powder $\longrightarrow$ Intermetallic $\longrightarrow$ Amorphous phase

$\mathrm{n}$ intermetallic or a solid solution forms before amorphization depends on the relative free energies of the two competing phases. On the other side, amorphization in ordered alloys seems to follow the sequence.

Ordered phase $\longrightarrow$ Disordered phase (loss of long-range order) fine grained (Nano-Crystalline) phase $\longrightarrow$ Amorphous phase

The time required for amorphization is dependent on the process variables, but they are typically shorter in case of MM than MA, due to alloying which does not need for MM.

Problems during MA:

There is a lot of advantages of using MA, but still, there are some disadvantages. It divides into three groups:

Powder Contamination: This is a significant problem during this process. It may be due to grinding medium, Vial, milling atmosphere etc.; It should minimize by using high purity metals, uses of balls and container of the same material and proper milling atmosphere etc.,

Limited Science content: The problem is not very clear about this technique. It may be due to a lot of variables involved in this process. 
Limited application: The industrial applications of MA is very few. Mainly demand seems to be about 350t of ODS materials, 200t of solder alloy, and 5t of Physical vapor deposition (PVD) target $(\mathrm{Cr}-\mathrm{V})$ alloys per year. The use of mechanochemical reactions in producing metals, alloys and compounds, catalyst materials, needs to be explored more.

The primary application of MA products is in the form of ODS alloys, which is very difficult to process with conventional ingot metallurgy (IM) methods. Due to a high homogeneous distribution of alloying elements during MA provides robust solution strengthened and precipitation- hardened alloys having more stability at elevated temperatures and overall improvement in properties.

Mechanochemistry is the term applied to the process in which chemical reactions and phase transformations take place due to applications of mechanical energy. This reaction might be utilized to produce pure metals, alloys and compounds at room temperature both in the laboratory and in large scale.

\subsubsection{3: Spark plasma sintering (SPS):}

Spark plasma sintering is one of the full densification processing routes to process biomaterials in the laboratory.

SPS is a new technique which takes place in lesser time (few minutes) to complete a sintering process compared to conventional sintering which may take hours or even days for the same. Due to high heating rate, it can attain for SPS process, high sintering rate is possible. Another reason is less holding time (5 to $10 \mathrm{~min}$ ) for SPS and for regular sintering holding time maybe 2-3 hours. Usually, heating rate attained in conventional furnaces is 5 to $8^{\circ} \mathrm{C}$ or maximum $10^{\circ} \mathrm{C}$, but in SPS heating rate might exceed $300^{\circ} \mathrm{C}$. For example, if the temperature of $1200^{\circ} \mathrm{C}$ is needed, then with conventional sintering it takes 3-4 hours minimum, but for SPS it takes only 4 minutes (Shen et al., 2002).

For conventional sintering, usually, a green compact need to be prepared externally using a suitable die and hydraulic $\mathrm{m} / \mathrm{c}$ for applying the necessary pressure. After that, the green compact sintered in a furnace. For SPS, the powder directly fed into the 
graphite dies and the die enclosed with suitable punches. Due to the advantage of high heating rate and less holding time, SPS can restrict the unwanted sintering reactions in highly reactive systems as opposed to conventional sintering and hence the formation of undesirable product phases can be avoided.

In 1990 Sumitomo heavy industries ltd. (Japan), commercially operated first plasma activated sintering (PAS) developed and Spark Plasma Sintering (SPS) machines with punches and dies made from electrically conductive graphite (Suárez, Fernández and Menéndez, 2013).

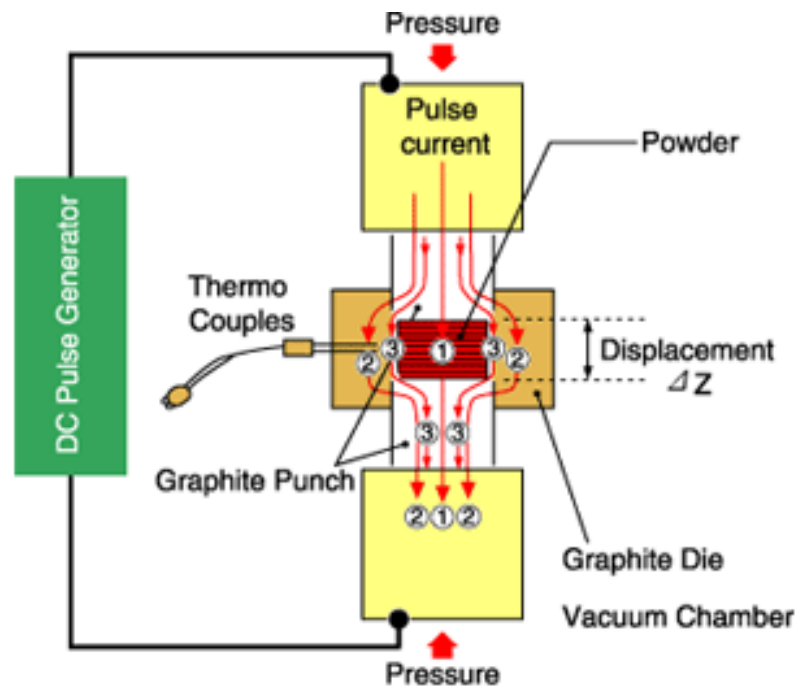

Figure: 2.5: An ON-OFF pulsed current path through the spark plasma sintering machine (Basu, 2011)

The SPS process is an electrical sintering technique which applies an ON-OFF DC pulse. The action of the electrical field causes rapid diffusion due to rapid migration of ions.

SPS process use for different specific purposes:

(1) For biomaterial: Erik O. Martz found a wide variety of applications in implantology with bulk Hydroxyapatite (HA) compacts and composites with HA (Martz et al., 1997). Aerospace engineering; New York Confirmed that HA shows 
limited stability at high temperatures and would dissociate into Tricalcium phosphate and tetra-calcium phosphate at $1300^{\circ} \mathrm{C}$ in the air or $1000^{\circ} \mathrm{C}$ in a vacuum (Engineering and York, 1994). High temperatures and long sintering duration are required for consolidation of HA powders by conventional techniques resulting in extreme grain coarsening or surface contamination, which can reduce the required mechanical properties. These problems can be minimized or eliminated by using Spark Plasma Sintering to avoid exposing the compacts to high temperatures for a long duration. Some scientists confirmed that it is possible to sinter HA powders by SPS at a temperature as low as $950^{\circ} \mathrm{C}$, and good performance regarding fracture toughness, Young's modulus and toughness. The obtained density is $99.6 \%$.

(2) For nuclear energy applications: from different literature, it is shown that SPS can densify the materials at lower temperatures and shorter times than those required in conventional processes. Spark plasma sintering minimizes grain growth, and it is, therefore, suitable to be used in materials requiring better machine performance. (O'Brien et al., 2009) reported about other works on encapsulation of plutonium dioxide or americium dioxide within a tungsten-based cermet using SPS technique.

(3) Materials with a low coefficient of thermal expansion: The ceramic materials obtained by using the conventional method of pressure less natural sintering have ordinarily low mechanical properties and Young's modulus. SPS is a solution for fabrication of sub-micron Las-Alumina composites (García-Moreno et al., 2011) and they also found that it is possible to sinter the composites up to theoretical density and even reach higher strength values at less current temperatures than required by conventional sintering. There are also different fabrication technologies like additive manufacturing, electron beam melting etc.,

Additive manufacturing or 3D printing is a process of making 3D solid objects from a digital model. This technology also used in the field of jewellery, footwear, industrial design, architecture, engineering and construction, automotive, aerospace, dental and medical industries, education, geographic information systems, civil engineering and many others. 
The significant applications of additive manufacturing are the prosthesis, which replaces damaged tissue with a non-living material (usually a metal alloy) in a form that at least approximates natural function. The best examples could be including dental crowns and bridges, heart valves and stents, knee and hip replacements (Oshida, 2013).

\section{5: Corrosion:}

For biomedical applications corrosion properties is very important. Alloys should be corrosion resistant. For $\beta$-Ti alloys normally corrosion behavior is better in comparison to $\mathrm{CP} \mathrm{Ti}$ and $\mathrm{Ti}-6 \mathrm{Al}-4 \mathrm{~V}$ which is also discussed by different authors (Niespodziana, Jurczyk and Jurczyk, 2008; Nishimura, 2011). Some authors also confirmed corrosion resistant character of Ti-15Mo which makes the alloy suitable for biomedical application (Kumar and Narayanan, 2008). 
Development of new high-performance Titanium alloys with Fe-addition for dental implants

28 | Page 


\section{Chapter 3: Material and methods}

There are mainly four phases carried out to achieve the main objective. For obtaining mainly three phases, we divided into different tasks which followed one by one:

Phase 1: To see the effect of Mo and Fe on Ti-Mo alloy by Elemental Blend

Phase 2: To perform mechanical alloying technique

Phase 3: for obtaining full density samples with spark plasma sintering Method

Phase 4: for obtaining $I_{\text {corr }}$, open circuit potential (OCP), Corrosion velocity, ion release rate by corrosion test

It is shown the overall project planning in flow diagram of our research work in figure 3.1 . 
Phase 1

Phase 2

Phase 3

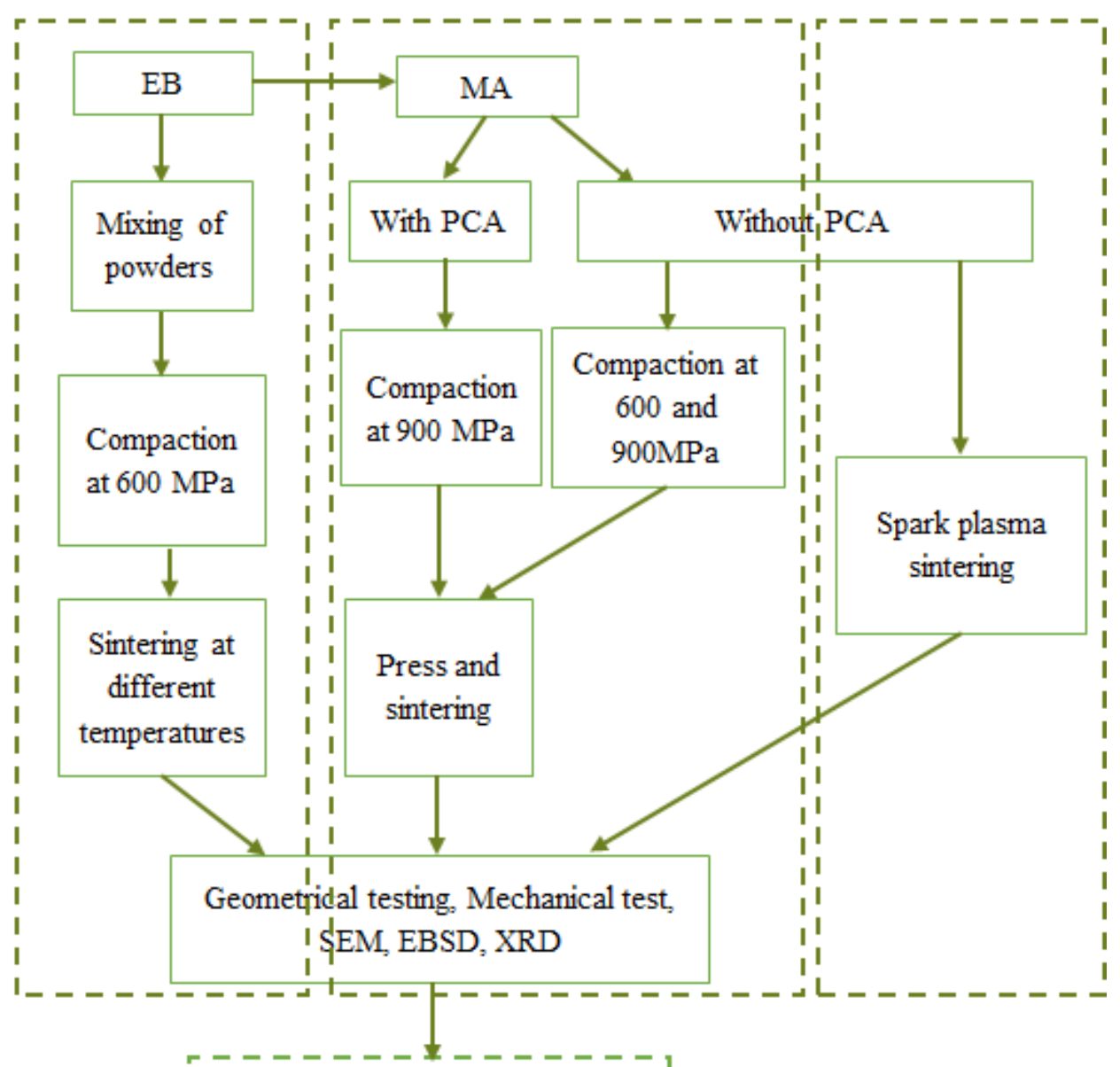

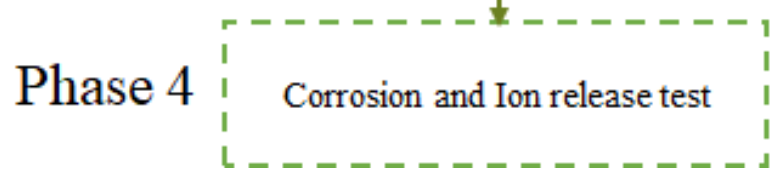

Figure 3.1: Flow diagram of overall project 


\section{1: Phase 1: To see the effect of Mo and Fe on Ti-Mo alloy by Elemental Blend}

Elemental Blend (EB) is a technique for mixing of elemental powders. It is a very simple and cost-effective technique, but the problem is lack of homogeneity due to less intense process. For this process powders needs to be mixed as per the weight calculated and then after if necessary, mixed the powders in tubular mixer with 150 rpm.

For obtaining different properties of alloy with Elemental Blend we have done different tasks:

Task 1:

Selection of

elemental

powders
Task 2:

Mixing of the

powder
Task 3:

Compaction

of the mixed

powders
Task 4:

Sintering of the

green samples
Task 5: To know geometrical properties of the sintered samples like porosity by Archimedes' test
Task 6: Determination of

mechanical properties

like flexural test, elastic

modulus, hardness of

the sintered alloy
Task 7:

Microstructural

characterization of the

sintered part of the

alloy

\subsection{1: Task 1: Selection of elemental powders:}

The main objective is to develop $\beta$-Ti alloys for biomedical uses. $\beta$-stabilizing elements $(\mathrm{Zr}, \mathrm{Mo}, \mathrm{Fe})$ are the better candidates for designing new $\beta$-type Ti-based alloys with lower elastic modulus, greater strength and corrosion resistance. Initially 
selection of elemental powders is the most important step towards development of new Ti- $\beta$ biomaterial alloys. Ti-Mo based biomaterials would be a promising candidate for the present study. It is started from Ti-Mo binary alloy followed by $\mathrm{Zr}$ with Ti-Mo alloy for better diffusion and further with Ti-Mo-Zr addition of Fe with different $\%(\mathrm{w} / \mathrm{w})$ and shown the effect of adding different $\%$ of $\mathrm{Fe}(1,2,3,4)$.

Ti-(12,15) Mo, Ti-(12,15) Mo-6Zr, Ti-(12,15) Mo-6Zr-(1,2,3,4) Fe is developed.

For obtaining this task we must select power supplier company of $\mathrm{Ti}, \mathrm{Mo}, \mathrm{ZrH}_{2}$ with high purity.

Supplier for the Titanium, Molybdenum is from Atlantic Equipment Engineers and Zirconium powders are Alfa Aesar with purity and powder size are listed in table 3.1. Supplier for Fe are Atlantic Equipment Engineers with purity $99.8 \%$ and powder size are (1-9) $\mu \mathrm{m}$.

Table 3.1: Elemental powder with its suppliers and quality

\begin{tabular}{|l|c|c|c|}
\hline \multicolumn{1}{|c|}{ Powder } & Supplier & Purity (\%) & Powder size \\
\hline Titanium & $\begin{array}{c}\text { Atlantic Equipment } \\
\text { Engineers }\end{array}$ & 99.7 & $45 \mu \mathrm{m}$ \\
\hline Molybdenum & $\begin{array}{c}\text { Atlantic Equipment } \\
\text { Engineers }\end{array}$ & 99.95 & $2-8 \mu \mathrm{m}$ \\
\hline Zirconium Hydride & Alfa Aesar & 99.95 & $44 \mu \mathrm{m}$ \\
\hline Iron & $\begin{array}{c}\text { Atlantic Equipment } \\
\text { Engineers }\end{array}$ & 99.8 & $1-9 \mu \mathrm{m}$ \\
\hline
\end{tabular}

During this study different alloys were developed with Elemental blend with different percentage of Fe. Initially Ti-(12,15\% w/w) Mo, Ti-(12, 15\% w/w) Mo-6Zr and Ti- $(12,15 \%$ w/w) Mo-6Zr-x $(1,2,3,4) \mathrm{Fe}$ Elemental powder were used with high purity $(>99.7 \%)$ for better geometrical properties and produces less problems during compaction and sintering process. Powder quality of the raw element can be seen in Figure 3.2 with different magnification analyzed in Scanning electron microscopy (SEM). 

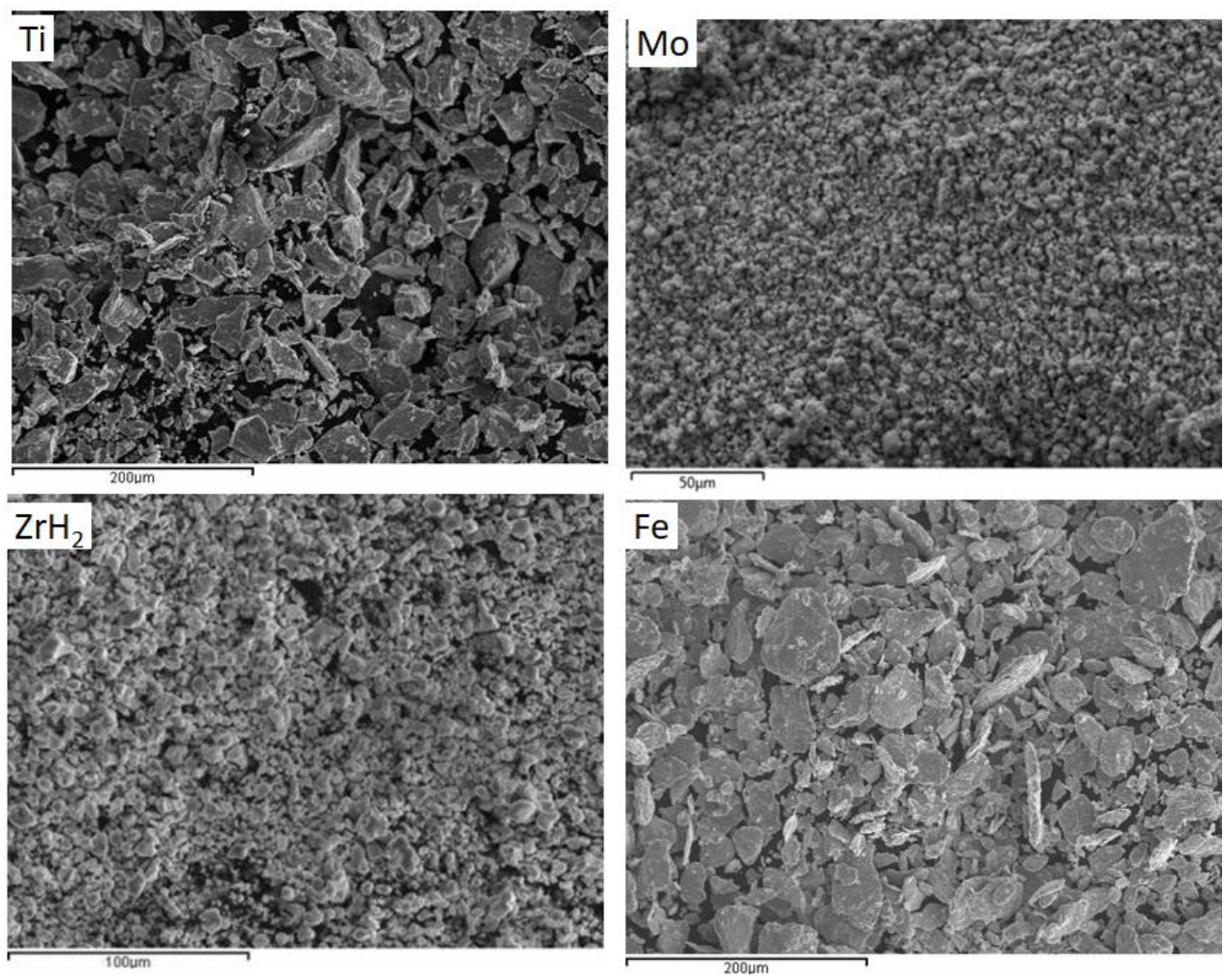

Figure 3.2: Supplied powder of $\mathrm{Ti}, \mathrm{Mo}, \mathrm{ZrH}_{2}$ and $\mathrm{Fe}$ with different magnification

Chemical analysis of $\mathrm{Ti}$, Mo and Fe elemental powders is summarized in table 3.2, which shows different contents of element available in the raw material. In $\mathrm{Ti}$ powder, gases were present as main impurities. Mo power was almost pure whereas Fe powder had acid insoluble in it. 
Development of new high-performance Titanium alloys with Fe-addition for dental implants

Table 3.2: Typical chemical analysis of supplier powder Ti, Mo and Fe

\begin{tabular}{|c|c|c|c|}
\hline Element & $\begin{array}{c}\text { For } \mathrm{Ti} \\
\% \text { by } w / w\end{array}$ & $\begin{array}{l}\text { For Mo } \\
\% \text { by w/w }\end{array}$ & $\begin{array}{c}\text { For } \mathrm{Fe} \\
\% \text { by w/w }\end{array}$ \\
\hline Oxygen & 0.22900 & - & - \\
\hline Nitrogen & 0.01600 & - & - \\
\hline Hydrogen & 0.02220 & - & - \\
\hline Iron & 0.01000 & 0.00200 & $\begin{array}{c}99.90000 \\
\text { min metals } \\
\text { basis }\end{array}$ \\
\hline Silicon & $<0.01000$ & 0.00600 & - \\
\hline Aluminum & $<0.01000$ & $<0.00100$ & - \\
\hline Sulfur & $<0.00100$ & $<0.00100$ & - \\
\hline Carbon & 0.01800 & 0.00300 & - \\
\hline Magnesium & 0.01000 & $<0.00100$ & - \\
\hline Manganese & 0.01000 & $<0.00100$ & - \\
\hline Sodium & $<0.01000$ & - & - \\
\hline Chlorine & $<0.01000$ & - & - \\
\hline Phosphorus & $<0.00200$ & - & - \\
\hline Titanium & $\begin{array}{c}99.90000 \mathrm{~min} \\
\text { metals basis }\end{array}$ & $<0.00100$ & - \\
\hline Calcium & - & $<0.00100$ & - \\
\hline Chromium & - & $<0.00100$ & - \\
\hline Copper & - & $<0.00100$ & - \\
\hline Nickel & - & 0.00300 & - \\
\hline Lead & - & $<0.00100$ & $<0.00040$ \\
\hline Tin & - & $<0.00100$ & - \\
\hline Molybdenum & - & $\begin{array}{c}99.98000 \mathrm{~min} \\
\text { metals basis }\end{array}$ & - \\
\hline Arsenic & - & - & $<0.00030$ \\
\hline Mercury & - & - & $<0.00020$ \\
\hline Acid insolubles & - & - & 0.03000 \\
\hline
\end{tabular}

The above analysis is carried out as part of our internal quality control testing and is based upon our analysis methods. The granulometric analysis of the supplied powder has been shown in figure 3.3. 

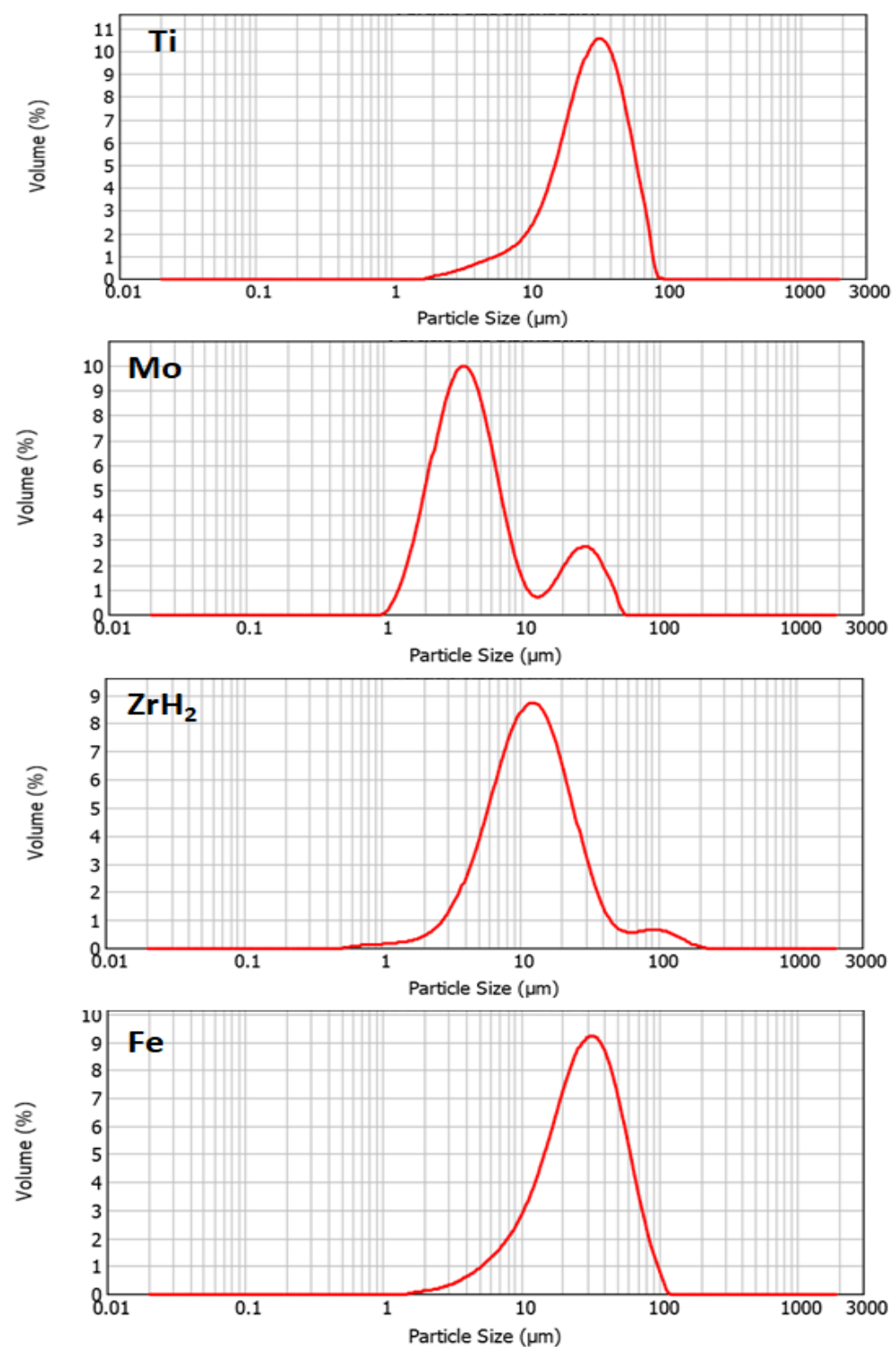

Figure 3.3: Granulometric analysis of $\mathrm{Ti}, \mathrm{Mo}, \mathrm{ZrH}_{2}$ and $\mathrm{Fe}$ supplied powder 


\section{Granulometry of raw powder:}

$\mathrm{D}(0.1), \mathrm{D}(0.5), \mathrm{D}(0.9)$ data provide by supplier as shown in table 3.3 , we mainly see the value of $\mathrm{D}(0.5)$ for average particle size.

Table 3.3: Granulometry of Ti, Mo, $\mathrm{ZrH}_{2}$ and Fe supplied powder.

\begin{tabular}{|c|c|c|c|}
\hline \multirow{2}{*}{ Material } & \multicolumn{3}{|c|}{ size $(\mu \mathrm{m})$} \\
\cline { 2 - 4 } & $\mathrm{D}(0.1)$ & $\mathrm{D}(0.5)$ & $\mathrm{D}(0.9)$ \\
\hline $\mathrm{Ti}$ & 11.064 & 29.227 & 55.929 \\
\hline $\mathrm{Mo}$ & 2.086 & 4.255 & 24.501 \\
\hline $\mathrm{ZrH} 2$ & 4.757 & 12.074 & 30.436 \\
\hline $\mathrm{Fe}$ & 9.850 & 28.110 & 59.888 \\
\hline
\end{tabular}

Selection of material is an essential step for powder metallurgy process. The first thing is to obtain alloys for powder metallurgy using selective raw material. The suppliers of metallic powder materials in our research are Alfa Aesar and Atlantic Equipment Engineers.

After selection of the elemental powder with higher purity, it is required to weight the powders according to stoichiometric relations.

\subsection{2: Task 2: Mixing of the powder}

In this step we must calculate the mass of the powder according to stoichiometric relation and composition of the required alloy. Mixing of the powder done in Bioengineering tubular mixer. 
Table 3.4: Elemental powder weight (real) for $\mathrm{EB} 1250^{\circ} \mathrm{C}$

\begin{tabular}{|c|c|c|c|c|c|}
\hline Alloy & \% Ti real & \%Mo real & $\begin{array}{c}\% \mathrm{ZrH}_{2} \\
\text { real }\end{array}$ & \%Fe real & $\rho t$ Real \\
\hline Ti12Mo & 88.01 & 11.99 & 0 & 0 & 4.83 \\
\hline Ti12Mo6Zr & 82.00 & 12.00 & 6.00 & 0 & 4.93 \\
\hline Ti15Mo & 85.00 & 15.00 & 0 & 0 & 4.92 \\
\hline Ti15Mo6Zr & 79.01 & 14.98 & 6.00 & 0 & 5.02 \\
\hline Ti12Mo6Zr1Fe & 81.00 & 12.00 & 6.00 & 1.00 & 4.95 \\
\hline Ti12Mo6Zr2Fe & 80.00 & 12.00 & 6.00 & 2.00 & 4.98 \\
\hline Ti12Mo6Zr3Fe & 79.00 & 12.00 & 6.00 & 3.00 & 5.00 \\
\hline Ti12Mo6Zr4Fe & 78.00 & 12.00 & 6.00 & 4.00 & 5.02 \\
\hline Ti15Mo6Zr2Fe & 77.00 & 15.00 & 6.00 & 2.00 & 5.07 \\
\hline Ti15Mo6Zr4Fe & 75.00 & 15.00 & 6.00 & 4.00 & 5.12 \\
\hline
\end{tabular}

Table 3.5: Elemental powder weight (real) for $\mathrm{EB} 1300^{\circ} \mathrm{C}$

\begin{tabular}{|c|c|c|c|c|c|}
\hline alloy & \% Ti real & \%Mo real & $\begin{array}{c}\% \mathrm{ZrH}_{2} \\
\text { real }\end{array}$ & \%Fe real & pt Real \\
\hline Ti12Mo6Zr1Fe & 81.00 & 12.00 & 6.00 & 1.00 & 4.95 \\
\hline Ti12Mo6Zr2Fe & 80.01 & 11.99 & 6.00 & 2.00 & 4.98 \\
\hline Ti12Mo6Zr3Fe & 79.01 & 11.99 & 6.00 & 3.00 & 5.00 \\
\hline Ti12Mo6Zr4Fe & 78.00 & 12.00 & 6.01 & 4.00 & 5.02 \\
\hline
\end{tabular}

Powder weight: normally weighing of powders done according to alloy (depends upon density), number of samples (normally 5), dimension of sample etc. $(30 * 12 * 6$ $\mathrm{mm}^{3}$ ). Density of alloy calculated according to stoichiometric relation of alloying powder. $\% \mathrm{Ti}_{\text {real }} \% \mathrm{Mo}_{\text {real }} \% \mathrm{ZrH}_{2}$ real and $\% \mathrm{Fe}_{\text {real. }}$. Real powder weight with different composition with both temperatures are tabulated in table 3.4 and 3.5. 
Development of new high-performance Titanium alloys with Fe-addition for dental implants

\subsection{3: Task 3: Compaction of the mixed powder}

Compaction is an important part of powder metallurgy. Powder filling is by manual method inside the compaction matrix. This equipment is Uni-axial compaction equipment which have a higher range of compaction pressure which we can used according to need or powder quality. This is suitable for compacting.

After getting mixtures of elemental powders by different method, it is needed to compact, press uniaxial with floating matrix. Compaction is important for production of green samples to achieve a better distribution of pressure applied on both sides of the Compact (top and bottom). For this purpose, it is determined the force to be applied according to the area exposed to each of the arrays. Knowing that $\mathrm{P}=\mathrm{F} / \mathrm{S}$, where $\mathrm{P}$ is the considered pressure, $\mathrm{F}$ is the force applied and the surface of the test piece $\mathrm{S}$. The force must be applied to maintain the pressure of compaction constant, in all samples, $600 \mathrm{MPa}$ obtaining.

The application of force to the compaction of the samples, is held at a constant speed and keeping the charge needed in each case for $15 \mathrm{~s}$.

After compaction of samples, green density of samples was analyzed which signifies the elemental powder bonding with another alloying element.

The compaction matrix is used for making samples for flexural samples. Normally 8-9 g powders were kept inside the slot made in this metal matrix. The volume of this slot is $32 \mathrm{~mm} * 12 \mathrm{~mm} * \mathrm{x} \mathrm{mm}$ (where $\mathrm{x}$ is thickness of samples), which is adjustable by the movement of both part of the matrix. During research, normally thickness is maintained as 5-6 mm. Matrix was properly cleaned with ethanol and lubricant before its use and after that properly covered with plastic to eliminate any possible chance of contamination from outside environment. The equipment used for compaction is Instron model 1343 equipped with a $500 \mathrm{kN}$ load cell which is shown in figure 3.4 (A), matrix for the bending sample compaction is shown in figure 3.4 (B) the punch of the cylindrical matrix of $20 \mathrm{~mm}$ diameter shown in figure 3.4 (C). 


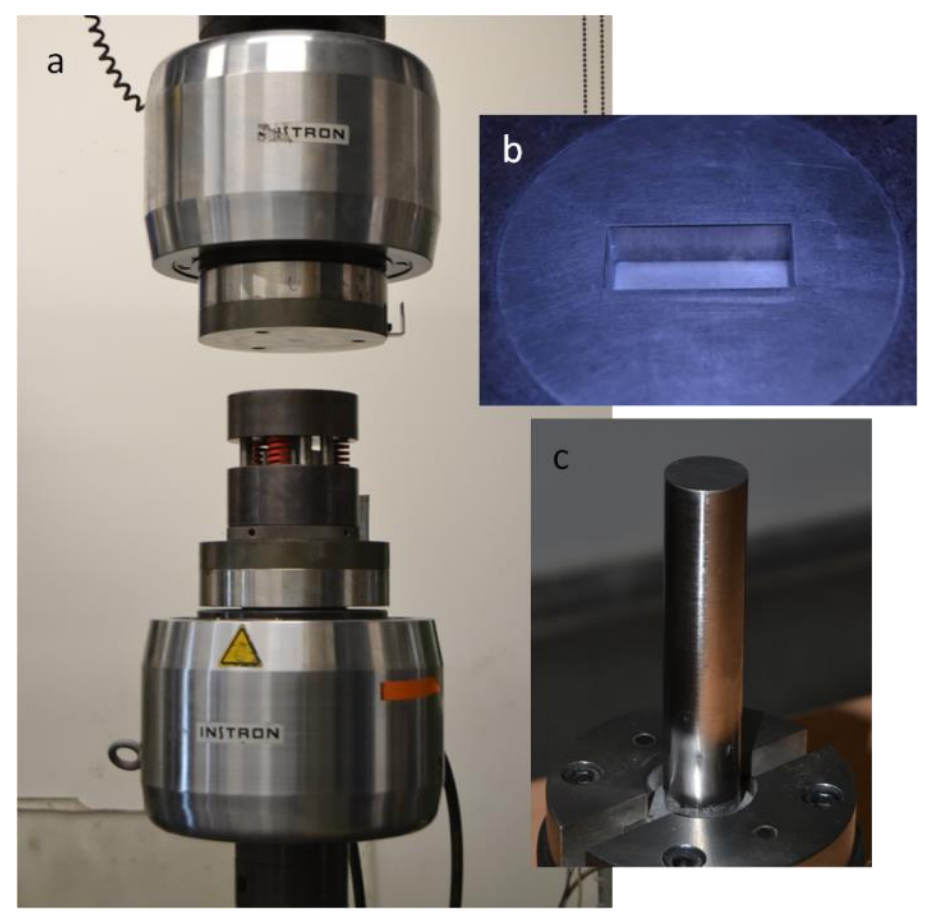

Fig 3.4: (a) Press of compaction with the floating matrix between the compression plates, (b) detail of the cavity of the rectangular matrix of $12 \times 30 \mathrm{~mm}$ and (c) detail of the punch of the cylindrical matrix of $20 \mathrm{~mm}$ diameter

After compaction of samples, green density of samples was analyzed which signifies the elemental powder bonding with another alloying element.

\subsection{4: Task 4: Sintering of the green sample}

From the literature, it is found that the mechanical properties is superior at $1250^{\circ} \mathrm{C}$ due to better dissolution of $\alpha$-particles into $\beta$ alloy (Guo et al., 2014). So, it is planned to use $1250^{\circ} \mathrm{C}$ temperature for our alloy or near to this temperature. 1250 and $1300^{\circ} \mathrm{C}$ are employed for better diffusion of the elements inside the alloy. Inside the furnace, vacuum is maintained to restrict the oxidation of the alloy. Argon atmosphere inside the furnace tube and vacuum pressure $\left(10^{-3}\right.$ to $\left.10^{-4} \mathrm{mbar}\right)$ are retained. Sintering cycle plays very important role for the mechanical properties of the alloy and the microstructure of the alloys. 


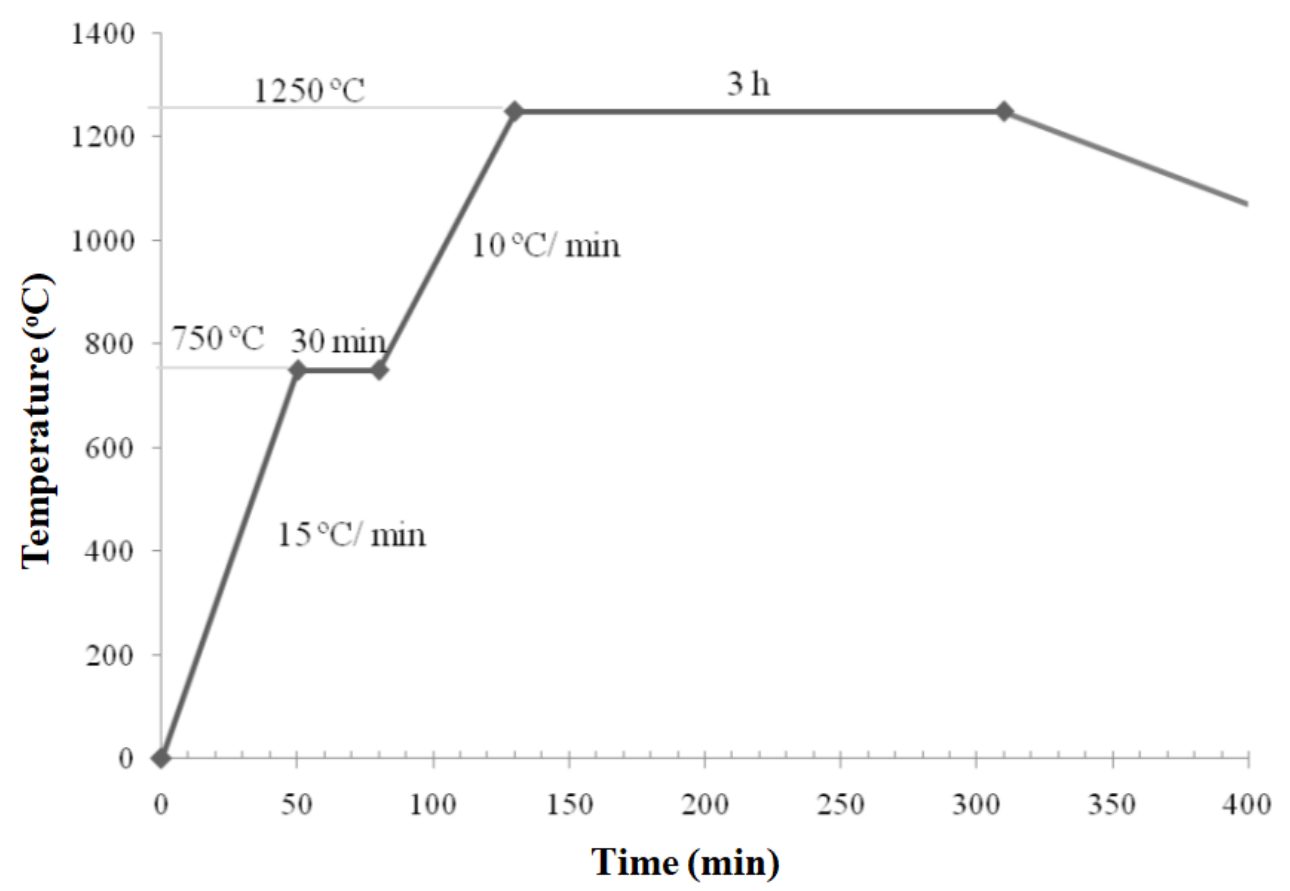

Figure 3.5: proposed sintering curve. Presents a heating $15 \mathrm{C} / \mathrm{min}$ up to a temperature of $750^{\circ} \mathrm{C}$, idle time of $30 \mathrm{~min}$ to homogenize the temperature of the material and the oven, another cycle up to $1250^{\circ} \mathrm{C}$ and $10^{\circ} \mathrm{C} / \mathrm{min}, 3$ hours sintering and cooling in furnace

The sintering cycle is maintained like figure (3.5) and the $1^{\text {st }}$ cycle is from $\left(0^{\circ} \mathrm{c}\right.$ to $750^{\circ} \mathrm{C}$ ) with $15^{\circ} \mathrm{C} / \mathrm{min}$ and $30 \mathrm{~min}$ holding time, then $\left(750^{\circ} \mathrm{C}-1250^{\circ} \mathrm{C}\right)$ with $10^{\circ} \mathrm{C} / \mathrm{min}$ heating rate and then holding time for 3 hours and then after cooling of the alloy. Vacuum sintering was done in the Furnace CARBOLITE HVT 1575 450. This technique of sintering was used for specimen produced by elemental blend and Mechanical alloying technique.

\subsection{5: Task 5: To know geometrical properties of the sintered samples like porosity by Archimedes' test}

Relative density/porosity is the primary characteristics of the sintered alloy. There are two type of porosity i.e., one is open porosity and other is closed porosity. Open 40 |Page 
porosity signifies porosity on the upper surface of the samples, closed porosity signifies the porosity inside the samples. Closed porosity also signifies the diffusion quality of the samples.

Porosity is determined by the Archimedes' test. From this test, closed porosity, open porosity, relative density is determined. Archimedes' test was done and then the specimen was kept inside the vacuum chamber with water for extraction of bubbles (approx. $30 \mathrm{~min}$.) and after that calculation ( $\mathrm{S}=$ Mass immersed in water after saturation mass and $\mathrm{M}=$ weight in the air after removing excess water) was done.

After calculation of relative density, porosity could be calculated very easily.

Porosity=100-relative density

So, if relative density is higher that means porosity should be smaller which is ambient for this study.

\subsection{6: Task 6: Determination of Mechanical properties of the sintered part of samples:}

For mechanical properties determination we must perform different mechanical test like flexural strength of the sintered part, determine elastic modulus of the alloy, Determination of Alloy Hardness.

\section{(Step 1)-flexural strength of the sintered part}

The flexural strength is the primary stage of the alloys to determine after sintering, flexural samples should be $30 * 12 * 6 \mathrm{~mm}^{3}$. Flexural strength, flexural modulus, stress, strain is determined. Basic mechanical properties of the samples are analyzed.

Flexural tests were done by Universal Shimadzu Autograph AG-100 kN Xplus. In this equipment, samples were kept horizontally (cross) to assure the break of samples. Initially data of displacement and force were taken, then the data of tests were recorded by Trapezium software and after that analysis of data were done as per the available information. With these results stress, strain, bending modulus and bending energy were analyzed.

Note: For our experiment

$\mathrm{L}=22 \mathrm{~cm}$ 
$\mathrm{H}=$ thickness of the sample

$\mathrm{D}=$ displacement

\section{(Step 2)-: Determine elastic modulus of the alloy}

Elastic modulus is the main mechanical properties for the biomaterials. It should be less (up to $30 \mathrm{GPa}$ ) approximately for hard tissue replacement. From the literature, it is found that most of the present alloys have more elastic modulus which is the main cause of stress shielding effect due to mismatching the modulus of the implant materials and the hard tissue. The main concern is to focus on minimizing the elastic modulus with the addition of different $\beta$ stabilizing elements like Mo, $\mathrm{Zr}$ and $\mathrm{Fe}$. Elastic modulus is calculated by Ultrasonic test with the calculation of longitudinal velocity $\left(\mathrm{V}_{\mathrm{L}}\right)$, Transversal velocity $\left(\mathrm{V}_{\mathrm{T}}\right)$. With the help of these two parameters, elastic modulus and Poisson's ratio are calculated for that alloy. These steps are followed for the calculation of parameters.

Note: for the longitudinal velocity and transversal velocity we need better surface contact, so we need to grind break samples after bending test with 220, 500, 1000 $\mathrm{SiC}$ grit size paper for $15 \mathrm{~s}$ approximately.

Experimental density is calculated by Archimedes' test ( $\left.\rho_{\text {exp }}\right)$, then thickness of sintered samples (t), and 2t, 3t and 4t are calculated respectively followed by calculation of longitudinal velocity $\left(\mathrm{V}_{\mathrm{L}}\right)$ and Transversal velocity $\left(\mathrm{V}_{\mathrm{T}}\right)$ using ultrasonic equipment with different setup. After getting the value of $\mathrm{V}_{\mathrm{L}}$ and $\mathrm{V}_{\mathrm{T}}, \mathrm{E}$ (elastic modulus) and Poisson's ratio are assessed.

The measurement of the modulus of elasticity by ultrasound is carried out in a Karl Deutsch Echo-graph 1090 equipment. After the preparation of the surface the measurements of the thickness of the samples have been taken, using a micro-meter of RS components with a distance between 0 and $25 \mathrm{~mm}$ and a sensitivity of 0.001 $\mathrm{mm}$, and the double and triple thickness values have been calculated. For the measurement of the longitudinal velocity, a DS 6 PB 4-14 probe with a longitudinal wave coupling 1571 of the Echo-trace houses was used. The transverse speed is measured using a YS 12 HB1 probe with a transverse wave coupling 1898.025 from the Karl Deutsch echo-graph. 
Method for determine elastic modulus:

- Measure the thickness as it has been shown in micrometre and adjust the thickness as it can be.

- Density used is t obtained by the method of Archimedes.

- If it is deformed due to the sintering, search the area of best contact.

- To place the sensor in the part convex.

\section{(Step 3)-Determination of Alloy Hardness}

Hardness is a measurement of the materials for the resistant quality to the compressive load for the shape change of those materials. Hardness of the metals should be larger than the plastics and polymers. Macroscopic hardness is generally characterized by strong intermolecular bonds, but the behavior of solid materials under force is complex; therefore, there are different measurements of hardness: scratch hardness, indentation hardness, and rebound hardness. For the metallurgic uses, indentation hardness is used. Common indentation hardness scales are Rockwell, Vickers, Shore, and Brinell. It would depend on the availability of the equipment in the laboratory. But preferred hardness would be Vickers's hardness. Nowadays most of the equipment provides the values automatically and some are still semi-automatic.

Note: We would perform 10 reading( start from $0 \mu \mathrm{m}$ of the sample and after each reading move $25 \mu \mathrm{m}$ and so on) for one sample and for one alloy we normally select 2 samples which is near to mean bending strength due to similar to that alloy. After that we normally take average of all the reading.

First, hardness was calculated with Rockwell Hardness equipment and then after it was converted into Vickers's hardness (HV).

Determination of Rockwell hardness (HRN 15N) was done by equipment Durometer-2-Centaur-model-HD 9-45. Normally for one specimen Rockwell hardness was calculated at 5-6 different point of the specimen. After that Rockwell hardness was converted into Vickers's hardness according to conversion table and average of all the values were taken. 


\subsection{7: Task 7: Microstructural characterization of the sintered part of the alloy:}

For analyzing microstructural properties of the sintered part, we have to perform different analysis like microhardness of the sintered part, fractography of the sintered part, back scattered/ secondary image with SEM, phase analysis of the alloy with the help of DRX, SEM and EBSD analysis.

\section{(Step 1): Microhardness of the alloy}

The micro harness values were calculated with Shimadzu HMV 2T equipment, figure 3.6, test force was $90.07 \mathrm{mN}$, image in rhombus shape was fixed and the area of the rhombus was hardness values.

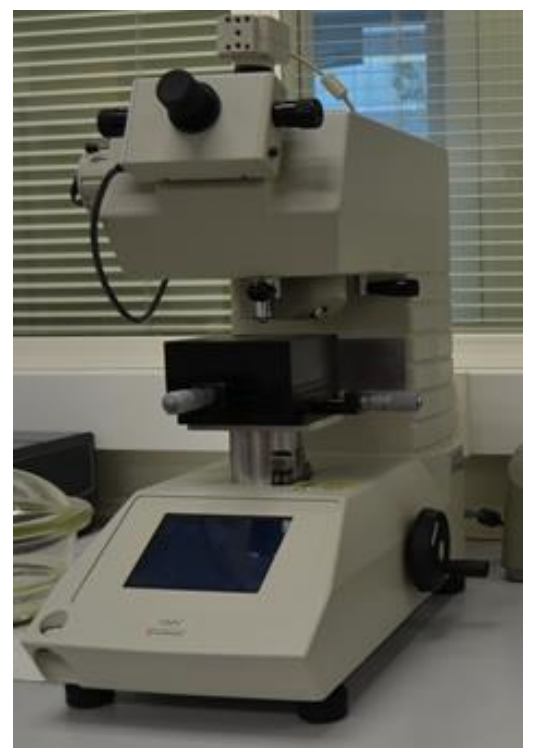

Fig 3.6: Microhardness equipment Shimadzu HMV 2T

Normally 10 reading were noted for one sample from $25 \mu \mathrm{m}$ of the starting point of the sample and move towards right direction to $25 \mu \mathrm{m}$ for each reading and then the average of the all the values were taken. 
(Step 2): Fractography analysis and Back scattered/ secondary image with Optical microscopy/SEM:

For Back scattered image (BSE) and secondary image of the alloy, all the samples are prepared followed by different steps like cutting of the samples, mounting of the samples and metallographic preparation of the samples. Select the sample which bending strength value is near to average value of 5 samples. Then cut the samples transversally $2 \mathrm{~mm}$ for analyses the fracture surface, then $1.5 \mathrm{~mm}$ for the SEM, after $1.5 \mathrm{~mm}$ cut for the DRX samples. After cutting of sample we should mount the samples with non-conductive resins with height $8 \mathrm{~mm}$ approx. Then after we must grind the samples with 220,500, $1000 \mathrm{SiC}$ grit size paper. Then after we must polish with $9 \mu \mathrm{m}$ and then $1 \mu \mathrm{m}$. Then it will be better to clean with Ultrasonic and very good dry with dryer.

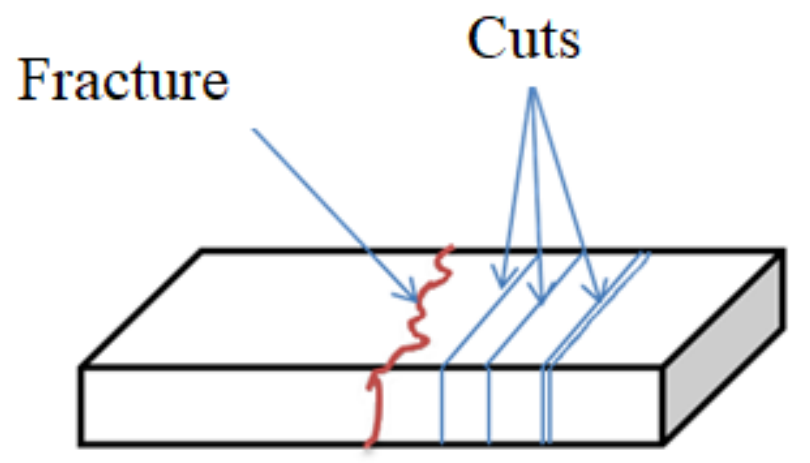

Figure 3.7: Fractured surface and after cut for microstructural analysis

Energy Dispersive Spectroscopy (EDS) is the main tool for analyzing the chemical composition of the alloy and mapping also done for the elemental analysis after mixing. Mixing of the different elements is observed by the different software like INCA, AZTEC. Percentage of different elements inside the alloy atomically and by weight is calculated. Fracture surface after break are shown in figure 3.7. 


\section{Scanning Electron Microscopy (SEM):}

Optical microscopy equipment available for our research is Nikon elipse LV 100 shown in figure 3.8 (A) and SEM equipment available in our lab is Jeol 6300 JSM shown in figure $3.8(\mathrm{~B})$.
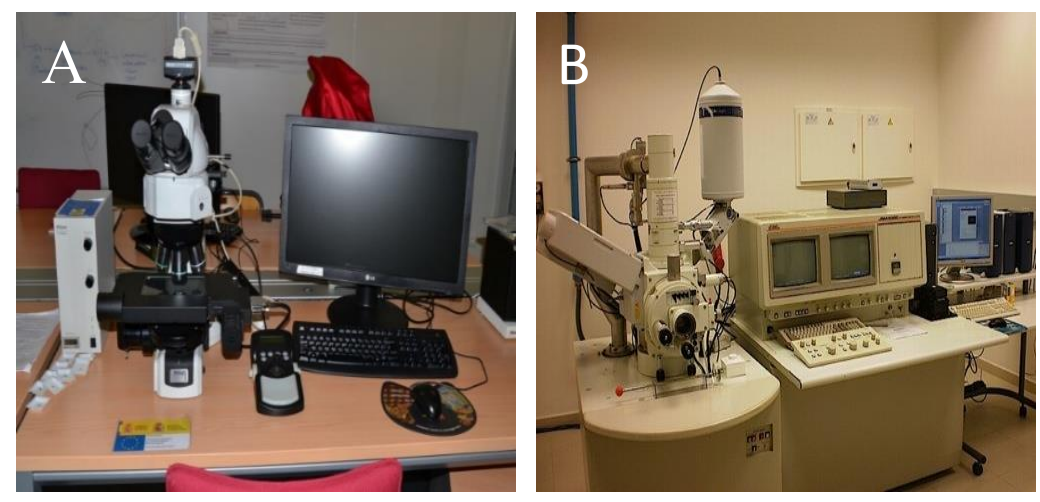

Figure 3.8: (A) Optical microscopy equipment (NIKON elipse LV 100) (B) SEM Jeol JSM 6300

During SEM First of all fractography of the samples were analyzed, then microstructure of the samples was done (Back scattered image and secondary image) with different magnification $(100 \mathrm{x} / 250 \mathrm{x}$ for general aspects), $500 \mathrm{x}$ for grain structure for the alloy, 1000x/2500x for specific analysis for some part of the microstructure. Inca software was applied for SEM analysis.

\section{(Step 3): Phase analysis of the alloy with the help of DRX, SEM and EBSD analysis}

Phase analysis is the important step for the alloy. It is focused to increase the percentage $\%$ of $\beta$-phase or to reach the $100 \% \beta$-phase. Phases would be determined by different techniques like XRD and EBSD analysis. The peaks in XRD technique show the effect of different elements on the alloy. XRD is a good tool to know about different phases. Different phases with different conditions of the alloy is compared like phase change due to change in sintering temperature, change in alloying element, change in percentage (\%) of alloying element and change in powder processing techniques. Shifting of the peak due to changing parameters of the alloys is seen. 
Preparation for EBSD samples is little bit different from SEM samples preparation. For EBSD samples we must use conductive resin for mounting and height of sample should be $8 \mathrm{~mm}$. We must dry sample very good for better analysis.

Depending on the microstructure observed in the cross sections of the samples, the crystalline orientation is studied using EBSD. With the help of pole figure and inverse pole figure, the orientation of the crystal present in the alloy is determined. There is a discussion briefly about the planar orientation of the crystal inside the alloy (Tarzimoghadam et al., 2015).

\section{Electron Back scatter Diffraction (EBSD)}

EBSD helps to view better microstructure and to determine disorientation of the alloy. Pole figure and inverse pole figure helps to know about orientation of the alloy. It also helps to calculate $\alpha / \beta$ phase of the alloy. Both techniques were very useful during this study; equipment available is Oxford instruments as shown in figure 3.9.

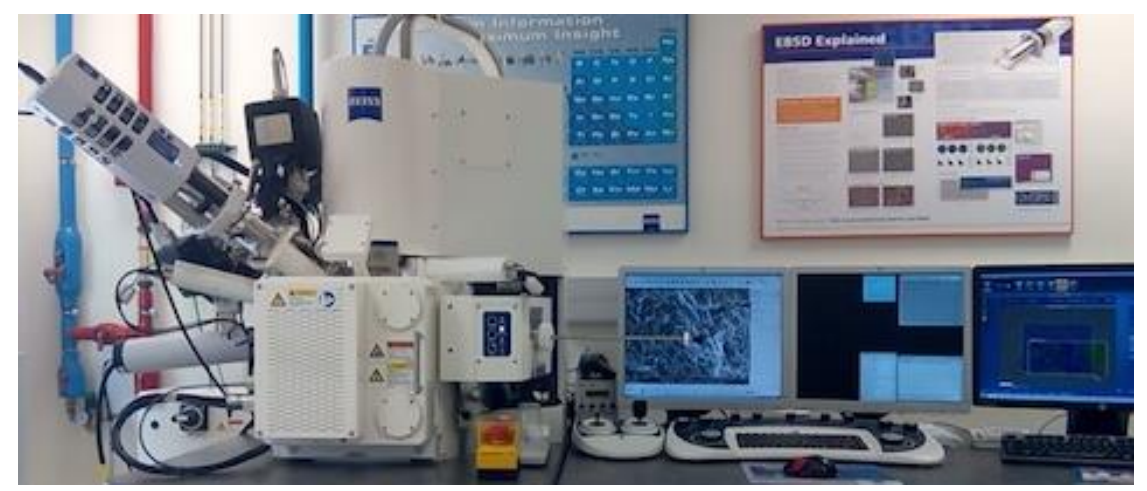

Fig. 3.9: EBSD Oxford Instruments.

AzTec and channel 5 software was used for EBSD analysis during research.

\section{XRD Analysis}

In order to have better surface finishing, the appropriate intensity in XRD ( $\mathrm{X}$ ray diffraction) was measured. Half part of the obtained specimen after breaking during flexural tests been prepared metallographically, following the same steps of assembly, thinning Grinding and polishing explained before. The measurements are 
performed on a Bruker D2Phaser device as shown in figure 3.10; using $30 \mathrm{kV}$ and a $0.05^{\circ}$ step every 10 seconds.

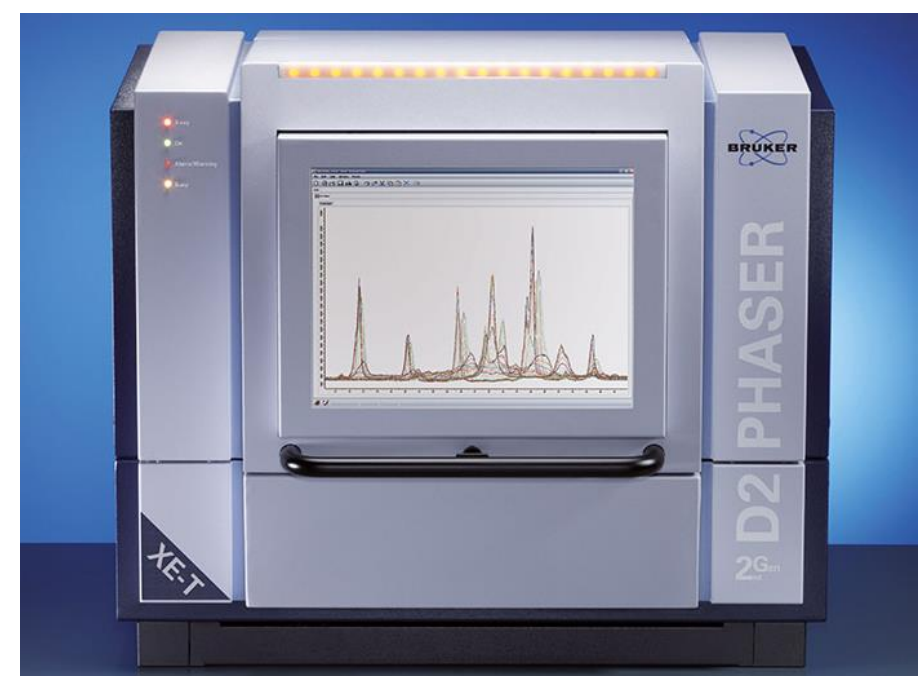

Figure 3.10: Bruker D2PHASER diffractometer.

The determination of the phases is done with the EVA software program. The amount of phase was determined for some cases through the application of the Rietvel method which requires the deconvolution of the peaks assigning the intensities to each of the phases, realized in the TOPAS software. The measurements were performed over the $2 \mathrm{q}$ range from 20 to 90 degrees at room temperature. 


\section{2: Phase 2: To perform mechanical alloying technique}

Mechanical alloying: (MA) is a solid-state powder processing technique involving repeated welding, fracturing, and re-welding of powder particles in a high-energy ball mill.

EB have lack of diffusion so, for overcome this problem we started work with MA techniques with different combinations. The sample we can work with mechanical alloying technique for better homogeneity, because this technique has more impact with high speed and more time. Starting we prefer to work without process control agent (PCA) due to $\mathrm{Ti}$ alloy got contaminated with PCA so, for neglect the contamination. We can start with less time and same compaction pressure.

\section{Task 1: Mixing of powder without process control agent (PCA)}

Task 2: Mixing of powder with process control agent (PCA)

\subsection{1: Task 1: Mixing of powder without process control agent (PCA)}

For obtain this task we have done mixing of different combination of milling speed and milling time without PCA. First, we planned to work with Ti-12Mo-6Zr-2Fe with 600 and $900 \mathrm{MPa}$, after the analysis of the results it is found that $900 \mathrm{MPa}$ have better mechanical properties in comparison to $600 \mathrm{MPa}$. All combination of mechanical alloying technique is shown in table 3.6.

Main parameters for mechanical alloying process are milling speed (in rpm), milling time (in min or h), Ball to powder ratio (BPR), Ball size (Diameter in $\mathrm{mm}$ ) and milling cycle.

During experiment different combination of milling speed and milling time were used for best homogeneous, better mechanical properties and better microstructure of the powder.

During experiment powder mixing for mechanical alloying was done in Camera gloves (Jacomex GPT2) as shown in figure 3.10. The equipment was used for 
weighing the elemental powder inside the glove box, restricted contamination and it is most important for Ti-alloy, because Ti is very reactive and mixing of elemental powders outside the glove box can lost powders and in some cases it may cause fire to avoid the addition of oxygen to the powder, which may modify the properties of Ti alloy. So, this equipment is utmost required to control such type of problems. This equipment is not available easily in each laboratory, so this is new and innovative idea to restrict the accidents like fire, lost or contamination of powders.

Table 3.6: Mechanical Alloying powder weight (real) with different parameters

\begin{tabular}{|c|c|c|c|c|c|c|}
\hline Alloy & Pw Real & Bw Real & (BPR)Real & $\begin{array}{c}\text { Milling } \\
\text { speed }\end{array}$ & $\begin{array}{c}\text { Milling } \\
\text { Time }\end{array}$ & $\begin{array}{c}\text { Compaction } \\
\text { pressure }\end{array}$ \\
\hline Ti12Mo6Zr2Fe & 398.53 & 39.14 & 10.18 & 300 & 45 & 600 \\
\hline Ti12Mo6Zr2Fe & 398.05 & 39.26 & 10.14 & 300 & 45 & 900 \\
\hline Ti15Mo & 349.09 & 23.28 & 15 & 300 & 45 & 900 \\
\hline Ti15Mo & 348.21 & 23.28 & 14.96 & 300 & 37 & 900 \\
\hline Ti15Mo & 366.42 & 24.281 & 15.09 & 300 & 52 & 900 \\
\hline Ti15Mo & 365.38 & 24.281 & 15.05 & 240 & 45 & 900 \\
\hline Ti15Mo & 363.88 & 24.282 & 14.99 & 180 & 45 & 900 \\
\hline Ti15Mo & 364.14 & 24.281 & 15 & 180 & 52 & 900 \\
\hline Ti15Mo & 364.15 & 24.282 & 15 & 240 & 52 & 900 \\
\hline Ti15Mo & 366.26 & 24.283 & 15.08 & 180 & 60 & 900 \\
\hline Ti15Mo6Zr2Fe & 360.26 & 23.492 & 15.35 & 180 & 45 & 900 \\
\hline Ti15Mo6Zr2Fe & 360.43 & 24.112 & 15.2 & 210 & 45 & 900 \\
\hline Ti15Mo6Zr2Fe & 359.23 & 23.982 & 14.98 & 180 & 52 & 900 \\
\hline
\end{tabular}

$\mathrm{P} w$ Real $=$ Powder weight during milling in real

$\mathrm{B}_{\mathrm{W} \text { Real }}=$ Ball weight during milling in real

$(\mathrm{BPR})_{\text {Real }}=$ ratio of ball weight to powder weight in real during milling 


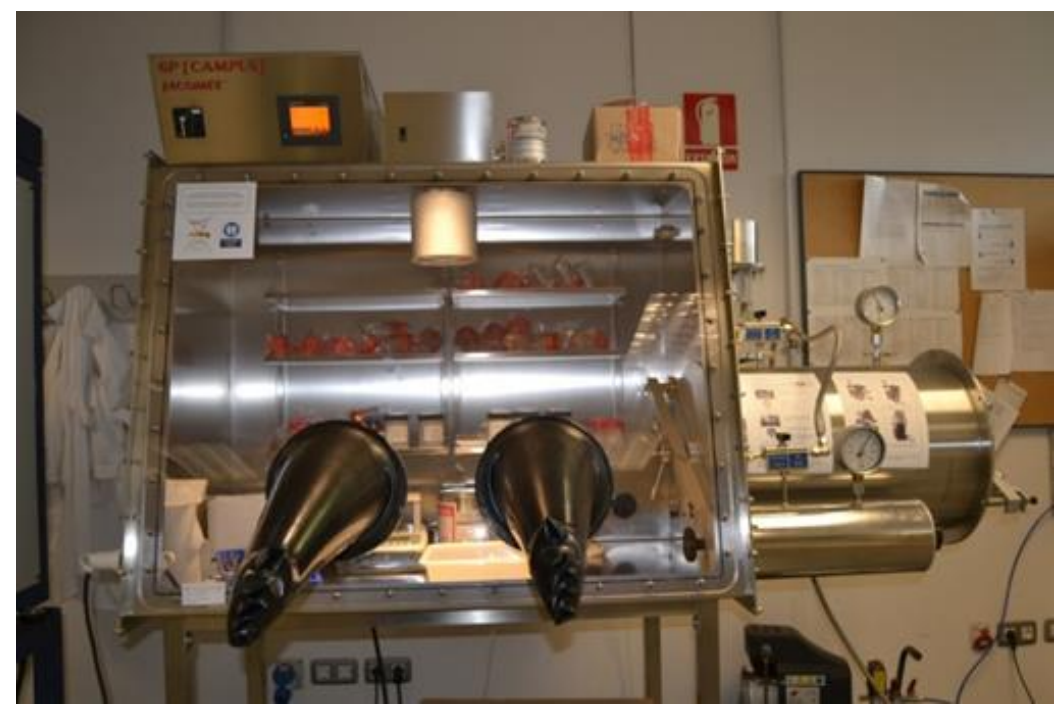

Figure 3.11: Glove box for mixing of powders for compaction

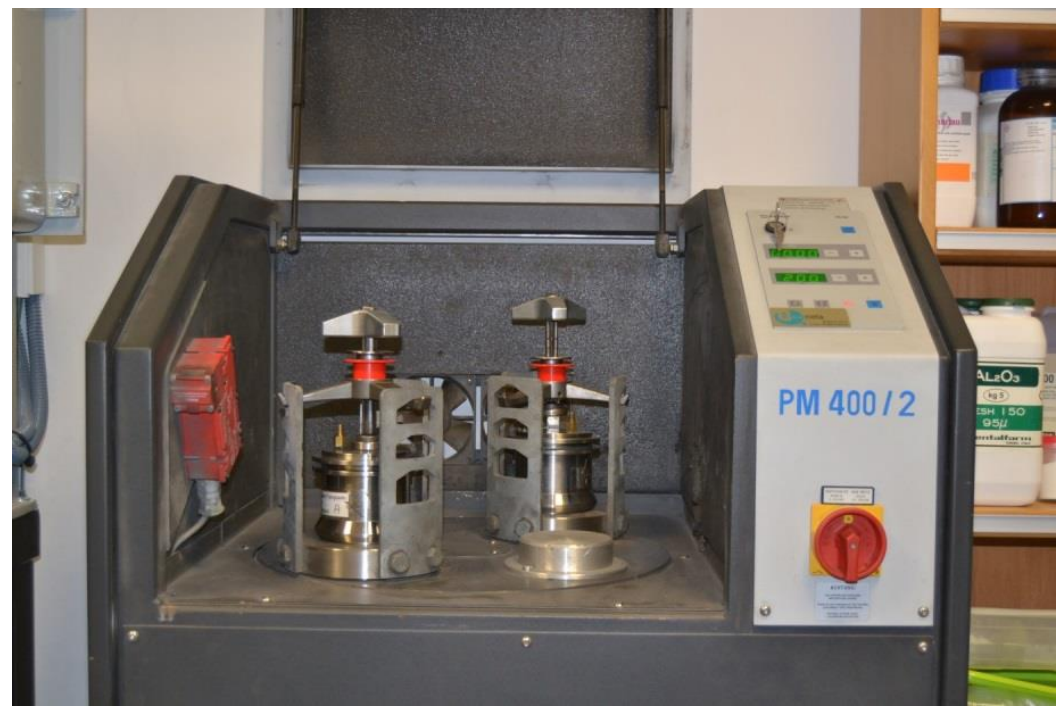

Figure 3.12: Planetary ball milling equipment (Retsch PM 400/2)

Retsch PM 400/2, as shown in figure 3.12, is used for mechanical alloying powder mixing process. The movement of the vial are in both direction i.e clockwise and 
anti-clockwise direction. For one whole cycle, we can put small cycles. For examples if we put one cycle for 1 hour, we can put small cycle for 5 min movement and 30 Sec idle. After each small cycle, direction of the vial change, like if starting cycle is clockwise then next cycle is anticlockwise direction and like that. We can control milling time and milling speed with this equipment. We also controlled small cycle (5 min.) and ideal time $(30 \mathrm{Sec})$ after each cycle. After each small cycle direction of rotation changed like from clockwise to anti-clockwise and vice-versa.

This equipment is suitable for homogeneous mixing of the powders, we put two jars (approx. one third filled) of powders and balls (made from Fe-Cr Steel). For MA, we mixed the powders in planetary ball milling equipment Retsch Pm 400/2 with two jars. Each jar should fill maximum one third with the ball and powders together. Weight of both jars should be equal approximately for balancing the rotating disk. We maintain the argon atmosphere inside the jars for minimizing the contamination problems. After finishing the milling cycle, it is needed to cool the jar for 45 minutes. Then after we opened the jar inside the chamber for minimizing the risk of fire. We extract the milling powders and done some test for analyzing the mixing quality of the alloy.

\section{Granulometry analysis}

This test is suitable for determining granulometric characteristics of the mixed powders. This test is suitable for all mixed powders, but we mainly used for mechanical mixing powders. It provides mainly $\mathrm{D}(0.1), \mathrm{D}(0.5)$ and $\mathrm{D}(0.9)$ values. $\mathrm{D}(0.1)$ signifies the diameter values which less than $10 \%$ values of entire lot of powders, $\mathrm{D}(0.5)$ signifies the diameter values of mixed powders is approximately $50 \%$ of the powders and D (0.9) signifies the diameter values of mixed powders is approximately $90 \%$ of the powders. $\mathrm{D}(0.5)$ values used the most due to it is approx. mean of all the powders lot value.

We put approx. 0.5 gram to the slot of granulometry and after each cycle of granulometric analysis, we need to clean properly to the entire slot with distilled water. The equipment for this test is Granulometry Malvern instruments Mastersizer 2000 dispersion unit AWM 2002 as shown in figure 3.13. 


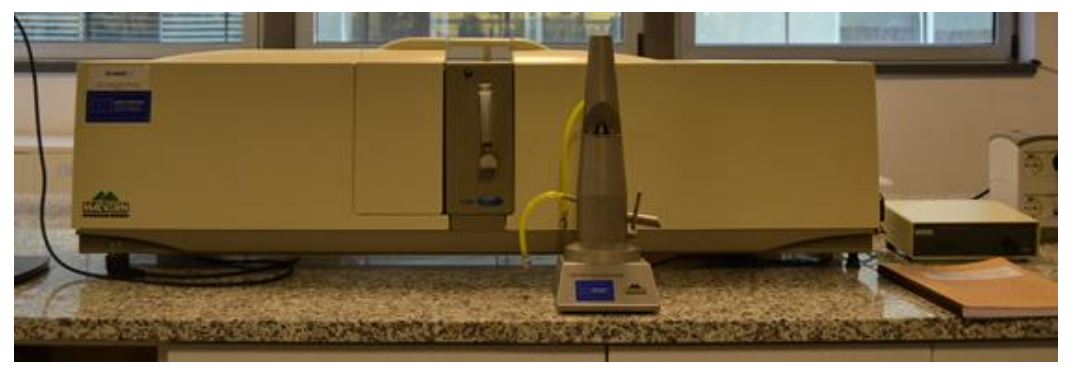

Figure 3.13: Malvern instruments Mastersizer 2000 dispersion unit AWM 2002.

\section{Fluidity}

Method for determination of flow rate of free-flowing metal powders using the hall apparatus with MPIF standard 03.

Mixed powder was kept in the matrix.

\section{2: Task 2: Mixing of powder with process control agent}

During literature survey most of the scientists used wax which maybe a cause of contamination for Ti alloy. Stearic acid was used as PCA during research. PCA was mixed with the Ti-15Mo-6Zr-2Fe the effects of grinding balls on the powders was analyzed. PCA was also used for controlling the heat generated during milling and timing was changed from ( $45 \mathrm{~min}, 52 \mathrm{~min}, 60 \mathrm{~min}-6 \mathrm{~h}, 24 \mathrm{~h}$ ) also shown in table 3.7. After $24 \mathrm{~h}$ there was a generation of more heat inside the jar and Weld powders with each other, but on $6 \mathrm{~h}$ better result was observed, and microstructure was also more homogenous than without PCA. Effect of ball size i.e. $5 \mathrm{~mm}$ dia. and $10 \mathrm{~mm}$ dia. was also observed. Effects of changing ball to powder ratio (BPR) from (10:1-15:1) were also visualized. Therefore, mechanical alloying provides a lot of possibility for more homogenized powders with different combination of parameters. 


\section{Development of new high-performance Titanium alloys with Fe-addition for dental implants}

Table 3.7: Different combinations of milling time and milling speed with different ball size for MA technique (With PCA)

\begin{tabular}{|l|c|c|}
\hline Alloy & Pressure & Milling condition \\
\hline Ti-15Mo-6Zr-2Fe MA & $900 \mathrm{MPa}$ & $6 \mathrm{~h}-180 \mathrm{rpm}(5 \mathrm{~mm}$ dia $)$ \\
\hline Ti-15Mo-6Zr-2Fe MA & $900 \mathrm{MPa}$ & $6 \mathrm{H}-180 \mathrm{rpm}(10 \mathrm{~mm}$ dia $)$ \\
\hline Ti-15Mo-6Zr-2Fe MA & $900 \mathrm{MPa}$ & $24 \mathrm{H}-180 \mathrm{rpm}$ (5 mm dia) \\
\hline
\end{tabular}

After mixing of the powder with PCA $1^{\text {st }}$ we must calculate ratio of obtained powder weight after mixing and initial powder weight; by this we can see the powder loss.

We analyzed mixing powder granulometry, fluidity (explained in section 3.2 .1 ) and geometrical test (like Archimedes' test), mechanical test (flexural test, micro hardness, elastic modulus) and microstructure according to section 3.1 .

\section{3: For obtaining full density samples with spark plasma sintering Method}

There is a possibility with mechanical alloying technique to found lots of porosity inside the sample, so for overcome this problem we can use some full density technique like spark plasma sintering (SPS).

One of the greatest challenges faced in powder metallurgy is identifying an appropriate sintering technique that can retain the developed microstructure while preventing or minimizing undesirable grain growth. Conventional sintering techniques usually lead to undesirable grain growth, reduced densification and loss of mechanical strength due to the long sintering time and high temperature required. Among the sintering processes that have been developed thus far, SPS is proofing to be effective in yielding fully dense metallic materials at relatively low temperatures and in very short sintering times. Such conditions are capable of preventing/reducing grain growth and minimizing the formation of undesired secondary phases that degrade the properties (Li et al., 2015).

For preparation of Spark plasma sintering powder firstly produce powders mix with mechanical alloying technique with $180 \mathrm{rpm}$ and $52 \mathrm{~min}$ and then sintered with SPS technique. During research, we explored with Ti-15Mo, Ti-15Mo-6Zr, Ti-15Mo$6 \mathrm{Zr}-2 \mathrm{Fe}$, Ti-12Mo-6Zr-2Fe with different parameters which are listed in table 3.8. 
Table 3.8: Processing parameters for SPS

\begin{tabular}{|l|l|c|c|}
\hline Alloy & Temperature & Pressure & Time \\
\hline Ti15Mo & $1100^{\circ} \mathrm{C}, 1150^{\circ} \mathrm{C}, 1200^{\circ} \mathrm{C}$ & & \\
\cline { 1 - 2 } Ti15Mo6Zr & $1100^{\circ} \mathrm{C}, 1150^{\circ} \mathrm{C}, 1200^{\circ} \mathrm{C}$ & \multirow{2}{*}{$50 \mathrm{MPa}$} & \multirow{2}{*}{$5 \mathrm{~min}$} \\
\cline { 1 - 2 } Ti15Mo6Zr2Fe & $1100^{\circ} \mathrm{C}, 1150^{\circ} \mathrm{C}, 1200^{\circ} \mathrm{C}$ & & \\
\cline { 1 - 2 } Ti12Mo6Zr2Fe & $1200^{\circ} \mathrm{C}$ & & \\
\hline
\end{tabular}
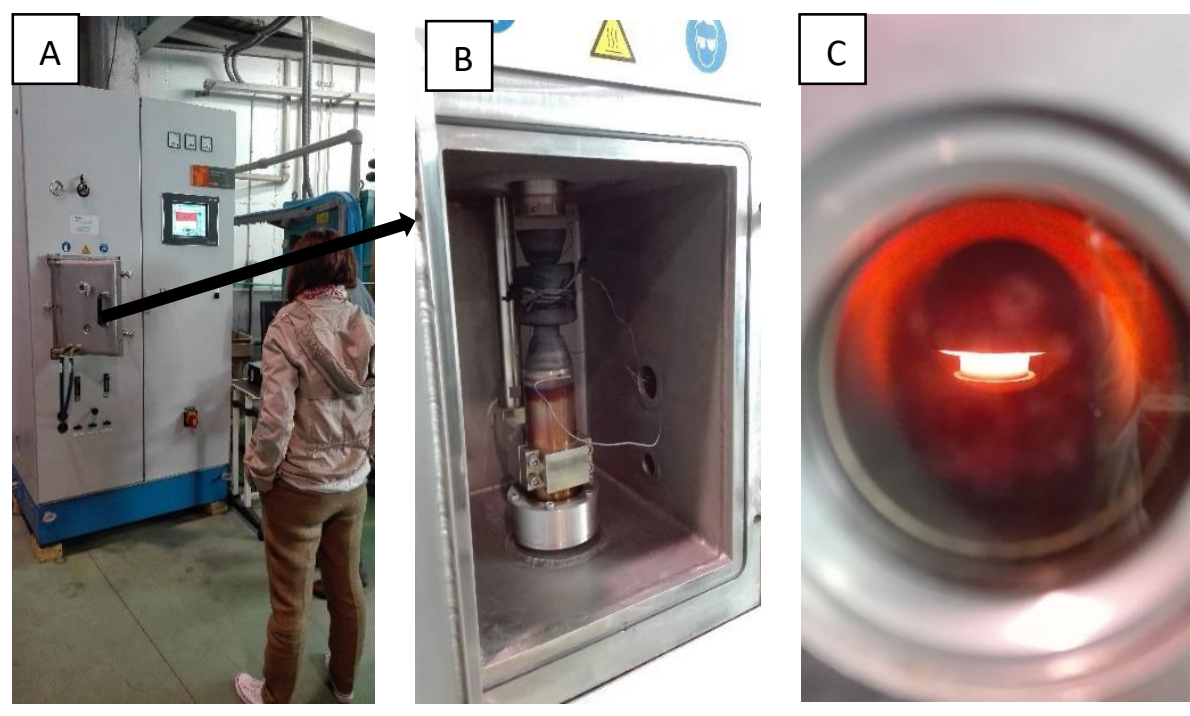

Figure 3.14: (A) FAST HP D 5/1 equipment (model S8451) from FCT (B) Setup for sintering with charcoal disk (C) Sample during sintering

The mechanical alloy has been made in a Retsch PM400 / 2 planetary mill at 180 rpm for 52 minutes and a dust / ball mass ratio 1/15. The sintering was carried out at $1100^{\circ} \mathrm{C}, 1150^{\circ} \mathrm{C}, 1200^{\circ} \mathrm{C}$ for 5 min on a FAST HP D 5/1 equipment (model S8451) from FCT, obtaining sintered products with a diameter of $30 \mathrm{~mm}$ and a thickness of $5 \mathrm{~mm}$. Disk for sintering is charcoal. This equipment is available in Tecnalia, San Sebastian, Spain; shown in figure 3.14. 
Development of new high-performance Titanium alloys with Fe-addition for dental implants

\section{4: Phase 4: for obtaining $I_{\text {corr, }}$ open circuit potential (OCP), Corrosion velocity, ion release rate by corrosion test}

A determining objective in the study of biomaterials is to check the behavior of these materials in a corrosive environment and determine their ability to release concentrations of harmful ions to the human body in working conditions.

\subsection{1: Ion Release Study:}

Regardless of their composition, all metal implants release different amounts of their components in the surrounding tissues where they have been inserted.

The samples will be prepared metallographically as explained above and the edges between resin and metal will be enameled to avoid penetration of the electrolyte into that opening, altering the test results. The test will consist of the complete immersion of the samples in a sealed bottle with $50 \mathrm{~mL}$ of artificial saliva at $37^{\circ} \mathrm{C}$ in the 2000207 SELECTA stove for 730 hours. These test conditions simulate a real time of 20 years with a defined cycle of 3 brushings of $2 \mathrm{~min}$ a day. The electrolyte to be used will be artificial saliva with the modification of Fusayama.

After the specified time, the samples will be carefully cleaned with distilled water and stored in a desiccator for further microscopic analysis. On the other hand, the artificial saliva solution will be analyzed by the ICP-OES VARIANT-715ES plasma spectroscopy equipment located in the ITQ, with which the concentrations of the different titanium, molybdenum, zirconium and iron ions released during immersion will be recorded. The analyzes will be carried out in collaboration with the Institute of Chemical Technology of the UPV. The results of this study should be as representative and reliable as possible, so each triplicate test will be carried out for each alloy.

\subsection{2: Phase 2: Study of resistance against corrosion}

In this stage several electrochemical tests will be carried out that allow us to characterize the processes that occur when Ti-Mo alloys are in contact with physiological environments that can be corrosive and try to identify the influence of surface fusion to this behavior. The Ti-Mo alloy is widely used in biomedical 
research today, so its behavior against corrosion in electrolytes such as $\mathrm{NaCl}$ or even artificial saliva is known. Not knowing to what extent, the properties of our samples are altered with superficial fusion in a corrosive environment like the buccal, it is interesting to study their behavior in artificial saliva at a controlled temperature (37 $\left.{ }^{\circ} \mathrm{C}\right)$.

The study will be carried out by means of a corrosion test with a three-electrode assembly, so that the sample will be the working electrode, the reference electrode will be $\mathrm{Ag} / \mathrm{AgCl}, 3 \mathrm{M} \mathrm{KCl}$ and the counter electrode will be platinum. The corrosion test will follow the routine proposed in Figure 3.15.

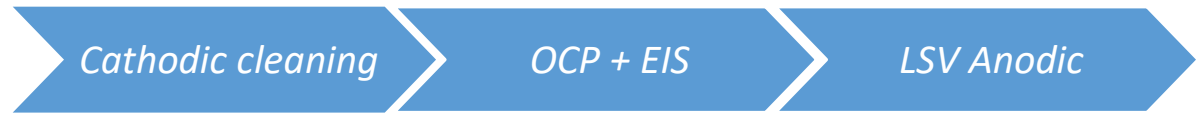

Figure 3.15. Scheme of the proposed routine for the study of resistance against corrosion.

\section{TASK 1: Cathodic Cleaning}

The first task of this stage will be the application of $-1.1 \mathrm{~V}$ for 5 minutes in order to activate the surface to be studied. First, within cathodic cleaning a potentiostatic test mode, a current range of $1 \mathrm{~mA}$ was defined along with the order to save the signal obtained for 300s. This stage is performed simply to homogenize the tested surfaces and achieve more representative results. The tested area of each sample was $1 \mathrm{~cm}$ in diameter, that is, $0.785 \mathrm{~cm}^{2}$. Three electrodes were assembled: working electrode (sample), reference electrode ( $\mathrm{Ag} / \mathrm{AgCl}, 3 \mathrm{MKCl})$ and counter electrode (platinum). When using the reference electrode $\mathrm{Ag} / \mathrm{AgCl}$ with a potential of $-0.205 \mathrm{~V}$ with respect to the hydrogen electrode (SHE, Standard Hydrogen Electrode), all the potentials were registered with respect to said potential. The necessary parameters (applied potential, voltammetry, applied current, definition of the hardware configuration) that allow the subsequent calculation of the searched parameters $\mathrm{E}_{\text {corr, }}$, $I_{\text {corr }}$ and $R_{p}$ were defined. 


\section{TASK 2: Open Circuit Potential (OCP)}

The determination of the open circuit potential allows us to know the surface state of the alloy studied, that is, the 'nobility' of the sample. It should be considered that the values obtained are completely dependent on the test conditions and can only be considered for comparison between the samples tested in this study. In this way, the value of the OCP will be obtained after the stabilization of the circuit potential without the passage of current for 30 minutes. Once the OCP curve is registered, the data we are looking for will be calculated using the average of the last 300 recorded values of the stabilized potential. The AUTOLAB AU51095 potentiostat was used together with the Nova 2.1.1 program to register and work with the test data. In this way, the potential in the absence of external current was recorded during 1800s, starting at $-1.1 \mathrm{~V}$ from the previous step. The result is a potential vs. curve. time, of which the average value of the last 300 values recorded as the value of the OCP is used.

TASK 3: Electrochemical Impedance Spectroscopy (EIS)

Next, the necessary parameters for the third step of the program were defined within the Frequency Response Analyzer (FRA) command to carry out the study of electrochemical impedance spectroscopy (EIS). Electrochemical impedance spectroscopy will quantify the response of the sample to a modulation at different frequencies of small amplitude sinusoidal potential. A frequency range of 104$0.005 \mathrm{~Hz}$ with an amplitude of $0.01 \mathrm{~V}$ was established. The results will be studied by a modelling software with which the necessary parameters that define the behavior of the interface between the metal and the electrolyte will be obtained. 
Table 3.9: Chi-square values obtained for the adjustment of the electric models of compact layer and double porous layer.

Compact layer circuit

The interpretation of the electrochemical behavior of the surface of the alloys is not simple, so it is necessary to consider an equivalent circuit that simulates the behavior against the corrosion test. The equivalent circuit that was proposed by Randles (Randles, 1947) has a great application in many electrochemical systems due to its simplicity (compact layer circuit). In this way, the data obtained in the impedance spectroscopy were analyzed with the Z View 2.0 software and they tried to adjust to the circuits of the table 3.9. In almost all samples, the diagram did not fit the results obtained, so it was necessary to test with other electrical circuits until it was found suitable for modeling the electrolytic behavior of the passive layers present in the alloys studied. In addition, it should be noted that the modification of the starting circuit was necessary since it could not really explain the electrolytic behavior of the material by modeling the passive layer as an ideal capacitor. Finally, the circuit that achieved a value of $\chi^{2}$ less than $10^{-3}$ was the electrical circuit that simulates a double porous layer, as will be explained in the subsequent results and discussion sections. 
TASK 4: Linear Sweep Voltammetry (LSV, Linear Sweep Voltammetry)

The last task of the corrosion test routine consists of a linear scan voltammetry at $0.0002 \mathrm{~V} / \mathrm{s}$. This technique is a potential sweep through which the current density will be recorded based on the applied potential that increases linearly. Faraday's law dictates that the reaction rate is proportional to the density of current flowing through the electrode / electrolyte interface. The curve obtained from the current density as a function of the potential will provide information on the kinetic processes of the electrochemical reactions that occurred during the test (Landolt, 2007).

The current density (i) corresponds to the sum of the partial anodic current density $\left(i_{a}\right)$ and the partial cathodic current). The concrete potential in which the total current changes from cathodic current to anodic current, is called corrosion potential ( $\left.\mathrm{E}_{\text {corr }}\right)$. Thus, the corrosion current density ( $\left.\mathrm{i}_{\text {corr }}\right)$ is the value of the current density when Ecorr is obtained, and it is characterized in that the current density of both halfreactions is equivalent $\left(i_{a}=i_{c}\right)$, as shown in figure 3.15. 


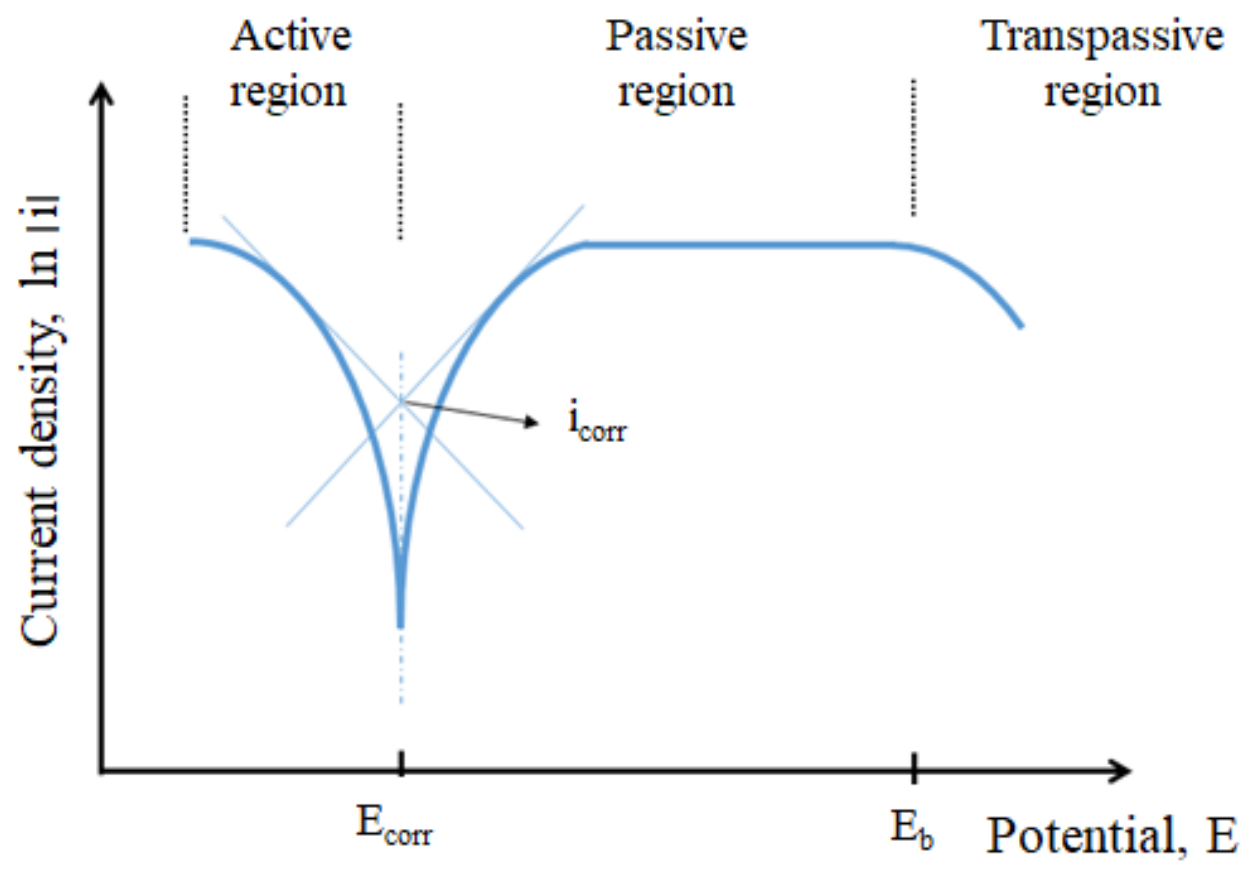

Figure 3.16: Scheme of a potentio dynamic polarization curve.

The corrosion rate of a material is a very interesting parameter to compare the corrosion behavior of the different alloys studied. It is directly related to the corrosion current density, so the material loss ratio will finally be obtained following equation (3.1) and the template in table 3.10. We assume that the polarization curves of the alloys studied follow the Butler-Volmer equation, where the lines that intersect at the point $\left(\mathrm{E}_{\text {corr }}, \mathrm{i}_{\text {corr }}\right)$ of the representation of the logarithm of the current intensity versus the potential are the slopes of Tafel ( $\beta_{\mathrm{a}}$ and $\beta_{\mathrm{c}}$ ).

$$
v_{c}=\frac{i \cdot M \cdot S}{\eta \cdot F \cdot \delta} \times 4.02 \times 10^{11}
$$




\section{Development of new high-performance Titanium alloys with Fe-addition for dental implants}

Table 3.10: Template to illustrate the calculation of the corrosion rate

\begin{tabular}{|l|l|}
\hline \multicolumn{2}{|l|}{ obtaining the corrosion speed, Vc $(\mu \mathrm{m} /$ year $)$} \\
\hline $\mathrm{i}_{\text {corr }}$ & Corrosion current density obtained by Tafel \\
\hline $\mathrm{M}$ & $\begin{array}{l}\text { Atomic mass }(\mathrm{g} / \mathrm{mol}) \text { calculated through atomic\% and weight } \\
\text { Atomic of each element. }\end{array}$ \\
\hline $\mathrm{S}$ & Exposed area $(\mathrm{cm} 3)$, in our case $0,785 \mathrm{~cm} 2$ \\
\hline $\mathrm{n}$ & Valence number of titanium (in our case it is 4$)$ \\
\hline $\mathrm{F}$ & Faraday constant, $96500 \mathrm{~A} \mathrm{~s} / \mathrm{mol}$ \\
\hline$\delta$ & Alloy Density $(\mathrm{g} / \mathrm{cm} 3)$ \\
\hline
\end{tabular}

Figure 3.16 shows the three regions that can be differentiated in a polarization curve: cathodic (active), anodic (passive) and transpassive region. The cathodic domain encompasses the potentials above $\mathrm{E}_{\mathrm{corr}}$ and the current is defined by the reduction of water and dissolved oxygen. At potentials below the $\mathrm{E}_{\text {corr }}$ is the active region, characterized by the ionic dissolution of the metal in the medium. On the other hand, the passive domain is characterized by the appearance of an oxide film that determines the dissolution rate of the metal to a specific potential. Finally, the properties of the passive film change in the transpassive domain and an increase in dissolution rate is observed. The transpasivation potential $\mathrm{E}_{\mathrm{b}}$ marks the end of the passive domain and the transition from the passive to the trans passive region.

$$
R_{p}=\frac{\beta \mathrm{a} \cdot \beta c}{2.3 I_{\text {corr }}(\beta \mathrm{a}+\beta \mathrm{c})}
$$


Table 3.11. Template to illustrate the calculation of polarization resistance

obtaining polarization resistance, $\mathrm{R}_{\mathrm{p}}(\Omega)$

Anodic Tafel slope $\left(\beta_{\mathrm{a}}\right)$

Earring of cathodic Tafel (V/A)

Corrosion Current Intensity (A)

Once the tests have been carried out and the potentiodynamic curves obtained, the values of the corrosion potential $\left(\mathrm{E}_{\text {corr }}\right)$ and the corrosion current density $\left(\mathrm{i}_{\text {corr }}\right)$ will be obtained. After this, the polarization resistance $\left(\mathrm{R}_{\mathrm{p}}\right)$ will be calculated using the mathematical ratio of equation 3.2, explained by the template in Table 3.11, and finally, an electrical model will be adjusted to try to understand the behavior of the metal / electrolyte. If the potentiodynamic curves allow it, it would be interesting to study other data such as passivation current density $\left(i_{p}\right)$ or the potential for breaking the passive layer $\left(\mathrm{E}_{\mathrm{b}}\right)$. 
Development of new high-performance Titanium alloys with Fe-addition for dental implants

64 |Page 


\section{Chapter 4: Results}

In this chapter, different mechanical test, microstructural characterization produced by different method such as Elemental Blend (EB), Mechanical Alloying (MA) and Spark plasma sintering (SPS) method are summarized.

First, Ti-xMo ( $x=12$ and 15 in weight $\%$ ) binary alloys were obtained, followed by ternary alloys with $6 \%$, in weight of $\mathrm{Zr}$, and quaternary alloys of the type Ti-xMo$6 \mathrm{Zr}$-yFe (where $\mathrm{x}=12 \& 15$ and $\mathrm{y}=1,2,3 \& 4$ in weight $\%$ ). As mentioned before, the mixing of the alloys was performed by two different routes: EB and MA. After analysing the mechanical alloying samples, big porosity was found inside the samples. So, for overcome this problem we start working with one of the full density method spark plasma sintering (SPS).

This chapter is divided in mainly 4 parts:

- Elemental blend (EB)

- Mechanical Alloying (MA)

- Spark plasma sintering (SPS)

- Corrosion test

\subsection{Elemental blend (EB)}

It started working with EB powder processing technique with Ti-Mo binary, ternary and quaternary alloy.

\subsubsection{Green Density (GD)}

After compaction, first step is to analyse green density by which compaction quality of the alloy could be understood.

Green density signifies density of the samples after compaction or density of the green sample. Theoretical density, Green density and relative green density of Ti-12Mo, Ti-15Mo, Ti-12Mo-6Zr, Ti-15Mo-6Zr and Ti-12Mo-6Zr-xFe are tabulated in table 4.1. Theoretical density is calculated with stoichiometric relation 
according to weight $\%$ of different powder elements present in the powder mix of the alloy. Green density is calculated with help of ratio of mass of green sample and volume of green samples and relative green density is calculated with ratio of green density and theoretical density. Lowest green density is calculated for Ti-12Mo-6Zr revealing powder packing for this alloy is lower comparatively than to other base alloys. From table 4.1; relative green density for all the alloy is near to $78 \%$.

Table 4.1: Theoretical density, green density and relative green density of elemental blended samples

\begin{tabular}{|c|c|c|c|}
\hline Alloys & $\begin{array}{c}\text { Theoretical density } \\
\left(\mathrm{g} / \mathrm{cm}^{3}\right)\end{array}$ & Green density $\left(\mathrm{g} / \mathrm{cm}^{3}\right)$ & $\begin{array}{c}\text { Relative green density } \\
(\%)\end{array}$ \\
\hline Ti-12Mo & 4.83 & $3.77 \pm 0.02$ & $78.00 \pm 0.43$ \\
\hline Ti-15Mo & 4.92 & $3.84 \pm 0.01$ & $78.11 \pm 0.19$ \\
\hline Ti-12Mo-6Zr & 4.93 & $3.82 \pm 0.01$ & $77.55 \pm 0.16$ \\
\hline Ti-15Mo-6Zr & 5.02 & $3.90 \pm 0.01$ & $77.64 \pm 0.30$ \\
\hline Ti-12Mo-6Zr-1Fe & 4.95 & $3.83 \pm 0.01$ & $77.42 \pm 0.12$ \\
\hline Ti-12Mo-6Zr-2Fe & 4.98 & $3.86 \pm 0.02$ & $77.48 \pm 0.34$ \\
\hline Ti-12Mo-6Zr-3Fe & 5.00 & $3.89 \pm 0.01$ & $77.70 \pm 0.27$ \\
\hline Ti-12Mo-6Zr-4Fe & 5.02 & $3.90 \pm 0.01$ & $77.64 \pm 0.13$ \\
\hline
\end{tabular}

\subsubsection{Porosity, Sintered Density and relative density:}

Porosity is mainly of two types (1) open porosity and (2) close porosity. Both type of porosity is calculated by Archimedes method Porosity. Sintering density is the most important parameter for the confirmation of the alloys for further analysis. It is calculated after sintering of the samples. It is the ratio of sintered mass with the sintered volume of the samples. Sintered density is calculated with Archimedes' method during our experiment. Relative sintered density is the ratio of sintered density and theoretical density of each sample. Open porosity (\%), close porosity $(\%)$, sintered density $\left(\mathrm{kg} / \mathrm{m}^{3}\right)$ and relative sintered density (\%) of Ti-12Mo, Ti-15Mo, Ti-12Mo-6Zr, Ti-15Mo-6Zr and Ti-12Mo-6Zr-xFe $\left(1250^{\circ} \mathrm{C}\right.$ and $\left.1300^{\circ} \mathrm{C}\right)$ are tabulated in table 4.2. Open porosity is minimum in case of Ti-12Mo-6Zr- $1 \mathrm{Fe}$ sintered at $1250^{\circ} \mathrm{C}$; which is $0.58 \%$ as shown in table 4.2 and maximum open porosity for $\mathrm{Ti}-12 \mathrm{Mo}-6 \mathrm{Zr}-3 \mathrm{Fe}$ sintered at $1300{ }^{\circ} \mathrm{C}$, which is $1.36 \%$. Close porosity is minimum in case of $\mathrm{Ti}-12 \mathrm{Mo}-6 \mathrm{Zr}-1 \mathrm{Fe}$ sintered at $1300{ }^{\circ} \mathrm{C}$, which is $0.97 \%$ and maximum open porosity for Ti- $15 \mathrm{Mo}$ sintered at $1250^{\circ} \mathrm{C}$; which is $1.93 \%$. Relative 
sintered density is maximum for Ti-12Mo- $6 \mathrm{Zr}-1 \mathrm{Fe}$ sintered at $1250^{\circ} \mathrm{C}$ which is 98.05 $\%$; as shown in last column of the table 4.2. Total porosity is the addition of close porosity and open porosity, which is reciprocal of the sintered density.

Table 4.2: Theoretical density, close and open porosity, sintered density and relative green of elemental blended samples

\begin{tabular}{|c|c|c|c|c|c|c|}
\hline Alloys & Temperature & $\begin{array}{l}\text { Theoretical } \\
\text { density } \\
\left(\mathrm{kg} / \mathrm{m}^{3}\right)\end{array}$ & $\begin{array}{l}\text { Open } \\
\text { porosity } \\
(\%)\end{array}$ & $\begin{array}{l}\text { Close } \\
\text { porosity } \\
(\%)\end{array}$ & $\begin{array}{l}\text { sintered } \\
\text { density } \\
\left(\mathrm{kg} / \mathrm{m}^{3}\right)\end{array}$ & $\begin{array}{l}\text { Relative } \\
\text { sintered } \\
\text { density }(\%)\end{array}$ \\
\hline Ti-12Mo & \multirow{8}{*}{$1250^{\circ} \mathrm{C}$} & 4.83 & 1.19 & 1.74 & $4.69 \pm 0.03$ & $97.07 \pm 0.63$ \\
\hline Ti-15Mo & & 4.92 & 1.19 & 1.93 & $4.77 \pm 0.03$ & $96.88 \pm 0.70$ \\
\hline $\begin{array}{c}\text { Ti-12Mo- } \\
6 \mathrm{Zr}\end{array}$ & & 4.93 & 0.90 & 1.13 & $4.83 \pm 0.01$ & $97.97 \pm 0.29$ \\
\hline $\begin{array}{c}\text { Ti-15Mo- } \\
6 \mathrm{Zr}\end{array}$ & & 5.02 & 1.53 & 1.18 & $4.89 \pm 0.04$ & $97.29 \pm 0.82$ \\
\hline $\begin{array}{l}\text { Ti-12Mo- } \\
6 \mathrm{Zr}-1 \mathrm{Fe}\end{array}$ & & 4.95 & 0.58 & 1.37 & $4.86 \pm 0.02$ & $98.05 \pm 0.49$ \\
\hline $\begin{array}{l}\text { Ti-12Mo- } \\
6 \mathrm{Zr}-2 \mathrm{Fe}\end{array}$ & & 4.98 & 0.94 & 1.44 & $4.86 \pm 0.04$ & $97.62 \pm 0.73$ \\
\hline $\begin{array}{l}\text { Ti-12Mo- } \\
6 \mathrm{Zr}-3 \mathrm{Fe}\end{array}$ & & 5.00 & 0.62 & 1.67 & $4.89 \pm 0.03$ & $97.70 \pm 0.56$ \\
\hline $\begin{array}{l}\text { Ti-12Mo- } \\
6 \mathrm{Zr}-4 \mathrm{Fe}\end{array}$ & & 5.02 & 0.71 & 1.89 & $4.89 \pm 0.02$ & $97.40 \pm 0.39$ \\
\hline $\begin{array}{l}\text { Ti-12Mo- } \\
6 \mathrm{Zr}-1 \mathrm{Fe}\end{array}$ & \multirow{4}{*}{$1300^{\circ} \mathrm{C}$} & 4.95 & 1.12 & 0.97 & $4.85 \pm 0.03$ & $97.91 \pm 0.62$ \\
\hline $\begin{array}{l}\text { Ti-12Mo- } \\
6 \mathrm{Zr}-2 \mathrm{Fe}\end{array}$ & & 4.98 & 1.11 & 1.23 & $4.86 \pm 0.02$ & $97.66 \pm 0.43$ \\
\hline $\begin{array}{l}\text { Ti-12Mo- } \\
6 \mathrm{Zr}-3 \mathrm{Fe}\end{array}$ & & 5.00 & 1.36 & 1.35 & $4.86 \pm 0.03$ & $97.29 \pm 0.64$ \\
\hline $\begin{array}{l}\text { Ti-12Mo- } \\
6 \mathrm{Zr}-4 \mathrm{Fe}\end{array}$ & & 5.02 & 1.26 & 1.42 & $4.89 \pm 0.06$ & $97.32 \pm 1.10$ \\
\hline
\end{tabular}

\subsubsection{Shrinkage calculation}

Shrinkage is the reduction of dimension of any material either it is solid or plastic. There are three types of shrinkage (1) volumetric shrinkage (\%) (2) Bulk shrinkage (\%) and (3) Linear shrinkage (\%). Volumetric shrinkage is calculated by the dimension loss after sintering, means contraction after compaction to sintering. Average value for volumetric shrinkage is $19.50 \%$ for alloys Ti-12Mo, Ti-15Mo, Ti-12Mo-6Zr, Ti-15Mo-6Zr and Ti-12Mo-6Zr-xFe as seen in table 4.3. Bulk 
shrinkage is the dimension loss with the area either length and width wise or length and thickness wise or width and thickness wise. For our case we calculated with length and width wise. On average bulk shrinkage is approximately $14 \%$ (little bit less than 14). Maximum bulk shrinkage is for Ti-12Mo-6Zr-2Fe which is 13.87 with deviation 0.16. Linear shrinkage is the unit dimensional loss with length, width or thickness; here we calculated with length dimension loss. Linear shrinkage is less in case of binary and ternary alloys in comparison with quaternary alloys. Maximum linear shrinkage is for Ti-12Mo-6Zr-2Fe which is 7.74 with deviation 0.13 . All the values are quite similar irrespective of the alloys.

Note: Deviation is calculated with 5 samples for each alloy.

Table 4.3: Volumetric shrinkage (\%), Bulk shrinkage (\%) and linear shrinkage (\%) of elemental blended samples

\begin{tabular}{|c|c|c|c|}
\hline alloys & Volumetric shrinkage (\%) & Bulk Shrinkage (\%) & Linear Shrinkage (\%) \\
\hline Ti-12Mo & $18.57 \pm 0.63$ & $13.74 \pm 0.35$ & $6.67 \pm 0.26$ \\
\hline Ti-15Mo & $18.51 \pm 0.34$ & $13.71 \pm 0.33$ & $6.62 \pm 0.21$ \\
\hline Ti-12Mo-6Zr & $19.50 \pm 0.21$ & $13.64 \pm 0.25$ & $6.56 \pm 0.14$ \\
\hline Ti-15Mo-6Zr & $19.38 \pm 0.35$ & $13.63 \pm 0.24$ & $6.53 \pm 0.14$ \\
\hline Ti-12Mo-6Zr-1Fe & $19.10 \pm 0.63$ & $13.84 \pm 0.14$ & $7.71 \pm 0.14$ \\
\hline Ti-12Mo-6Zr-2Fe & $19.07 \pm 0.53$ & $13.87 \pm 0.16$ & $7.74 \pm 0.13$ \\
\hline Ti-12Mo-6Zr-3Fe & $18.97 \pm 0.34$ & $13.83 \pm 0.10$ & $7.69 \pm 0.13$ \\
\hline Ti-12Mo-6Zr-4Fe & $18.84 \pm 0.14$ & $13.60 \pm 0.07$ & $7.62 \pm 0.10$ \\
\hline
\end{tabular}

\subsubsection{Bending strength (MPa), Toughness (J) and elongation (\%) of sintered samples}

Flexural strength, also known as modulus of rupture, or bend strength, or transverse rupture strength is a material property, defined as the stress in a material just before it yields in a flexure test.

Bending strength of different Ti-Mo alloys are shown in table 4.4, Bending strength for Ti-15Mo is higher which is approx. (2161 MPa), but this is much higher, for biomedical applications (650-850 MPa). But higher strength is not a big problem; 
even it is better for long term implant. From the table 5.4, addition of $\mathrm{Zr}$ reduced the bending strength.

Bending strength of Ti-12Mo-6Zr-xFe alloys with $1250^{\circ} \mathrm{C}$ and $1300^{\circ} \mathrm{C}$ are also shown in table 5.4. Increase of $\%$ of Fe reduced the value of bending strength i.e. value for Ti-12Mo-6Zr-1Fe is highest and Ti-12Mo-6Zr-4Fe is lowest among quaternary alloys. With increase in temperature from $1250^{\circ} \mathrm{C}$ to $1300^{\circ} \mathrm{C}$ the increment in strength found for Ti-12Mo-6Zr-1Fe and for Ti-12Mo-6Zr-2Fe as shown in table 4.4 and vice versa for Ti-12Mo-6Zr-3Fe and Ti-12Mo-6Zr-4Fe.

Bending strength decreases from $2023 \mathrm{MPa}$ (for Ti-15Mo) to $766 \mathrm{MPa}$ (for Ti$15 \mathrm{Mo}-6 \mathrm{Zr}-4 \mathrm{Fe}$ ) approximately $62 \%$ decrement. In all the alloys listed in the table 4.4 ; it is clearly shown that addition of $\mathrm{Zr}$ and Mo reduces bending strength.

Toughness is energy involved in breaking samples during bending test. The value is maximum for Ti-12Mo which value is $50.37 \mathrm{~J}$ and the lowest value is for Ti-12Mo$6 \mathrm{Zr}-4 \mathrm{Fe}$ (sintered at $1300^{\circ} \mathrm{C}$ ) which value is $6.05 \mathrm{~J}$ which is approx. $90 \%$ less than Ti-12Mo. Normally from the table, it is clear that increment of $\%$ of Fe decreases the value of tenacity.

Elongation is maximum in case of $\mathrm{Ti}-12 \mathrm{Mo}-6 \mathrm{Zr}$ which is $5.95 \%$ (sintered at 1300 ${ }^{\circ} \mathrm{C}$ ) and least for Ti-12Mo-6Zr-4Fe which value is $2.42 \%$, which is approx. $60 \%$ less than Ti-12Mo-6Zr.

Note: Standard deviation calculated with 5 samples for each test. 
Development of new high-performance Titanium alloys with Fe-addition for dental implants

Table 4.4: Bending strength (MPa), Toughness (J) and Elongation (\%) of elemental blended samples

\begin{tabular}{|c|c|c|c|c|}
\hline Alloys & Temperature & $\begin{array}{l}\text { Bending Strength } \\
\text { (MPa) }\end{array}$ & Toughness (J) & $\begin{array}{c}\text { Elongation } \\
(\%)\end{array}$ \\
\hline Ti-12Mo & \multirow{8}{*}{$1250^{\circ} \mathrm{C}$} & $2023 \pm 107$ & $50.37 \pm 10.36$ & $5.67 \pm 0.96$ \\
\hline Ti-15Mo & & $2161 \pm 28$ & $48.52 \pm 2.37$ & $5.28 \pm 0.40$ \\
\hline Ti-12Mo-6Zr & & $1932 \pm 106$ & $36.59 \pm 5.03$ & $5.95 \pm 0.13$ \\
\hline Ti-15Mo-6Zr & & $1659 \pm 131$ & $26.07 \pm 4.48$ & $4.27 \pm 0.34$ \\
\hline Ti-12Mo-6Zr-1Fe & & $1521 \pm 71$ & $23.31 \pm 2.13$ & $4.60 \pm 0.28$ \\
\hline Ti-12Mo-6Zr-2Fe & & $1195 \pm 71$ & $14.90 \pm 1.80$ & $3.96 \pm 0.25$ \\
\hline Ti-12Mo-6Zr-3Fe & & $971 \pm 88$ & $10.28 \pm 1.70$ & $3.34 \pm 0.21$ \\
\hline Ti-12Mo-6Zr-4Fe & & $766 \pm 87$ & $7.13 \pm 1.65$ & $2.70 \pm 0.30$ \\
\hline Ti-12Mo-6Zr-1Fe & \multirow{4}{*}{$1300^{\circ} \mathrm{C}$} & $1725 \pm 134$ & $32.53 \pm 5.52$ & $4.86 \pm 0.36$ \\
\hline Ti-12Mo-6Zr-2Fe & & $1390 \pm 46$ & $20.43 \pm 1.24$ & $4.34 \pm 0.12$ \\
\hline Ti-12Mo-6Zr-3Fe & & $929 \pm 55$ & $9.79 \pm 0.85$ & $3.12 \pm 0.30$ \\
\hline Ti-12Mo-6Zr-4Fe & & $666 \pm 114$ & $6.05 \pm 1.35$ & $2.42 \pm 0.28$ \\
\hline
\end{tabular}

\subsubsection{Elastic modulus $E_{U}$ (GPa), Poisson's coefficient and hardness (HV) of sintered samples}

Table 4.5 denotes the values of elastic modulus of elemental blend samples, Poisson's coefficient during elastic modulus testing which is denoted as $v$ and hardness of the samples which is tabulated in column 1, column 2 and column 3 of the table 5.5 respectively. Elastic modulus is the main property for the biomedical applications which should be less like approx. 28-35 GPa. 
Table 4.5: Elastic modulus (EU), Poisson's coefficient and Hardness of elemental blended samples

\begin{tabular}{|c|c|c|c|c|}
\hline Alloys & Temperature & $\mathrm{Eu}(\mathrm{GPa})$ & 0 & Hardness (HV) \\
\hline Ti-12Mo & \multirow{8}{*}{$1250^{\circ} \mathrm{C}$} & $104.89 \pm 1.38$ & $0.33 \pm 0.0033$ & $283 \pm 28$ \\
\hline Ti-15Mo & & $103.84 \pm 0.82$ & $0.33 \pm 0.0018$ & $309 \pm 19$ \\
\hline Ti-12Mo-6Zr & & $102.90 \pm 0.86$ & $0.34 \pm 0.0019$ & $309 \pm 30$ \\
\hline Ti-15Mo-6Zr & & $98.55 \pm 0.83$ & $0.34 \pm 0.0017$ & $322 \pm 29$ \\
\hline $\begin{array}{c}\text { Ti-12Mo-6Zr- } \\
1 \mathrm{Fe}\end{array}$ & & $103.58 \pm 0.81$ & $0.33 \pm 0.0009$ & $542 \pm 12$ \\
\hline $\begin{array}{c}\text { Ti-12Mo-6Zr- } \\
2 \mathrm{Fe}\end{array}$ & & $100.70 \pm 1.31$ & $0.33 \pm 0.0025$ & $512 \pm 36$ \\
\hline $\begin{array}{c}\text { Ti-12Mo-6Zr- } \\
3 \mathrm{Fe}\end{array}$ & & $95.23 \pm 0.60$ & $0.34 \pm 0.0031$ & $493 \pm 19$ \\
\hline $\begin{array}{c}\text { Ti-12Mo-6Zr- } \\
4 \mathrm{Fe}\end{array}$ & & $96.85 \pm 0.58$ & $0.34 \pm 0.0007$ & $467 \pm 23$ \\
\hline $\begin{array}{c}\text { Ti-12Mo-6Zr- } \\
1 \mathrm{Fe}\end{array}$ & \multirow{4}{*}{$1300^{\circ} \mathrm{C}$} & $103.69 \pm 0.76$ & $0.33 \pm 0.0020$ & $500 \pm 26$ \\
\hline $\begin{array}{c}\text { Ti-12Mo-6Zr- } \\
2 \mathrm{Fe}\end{array}$ & & $102.74 \pm 0.33$ & $0.33 \pm 0.0013$ & $499 \pm 29$ \\
\hline $\begin{array}{c}\text { Ti-12Mo-6Zr- } \\
3 \mathrm{Fe}\end{array}$ & & $95.00 \pm 1.42$ & $0.33 \pm 0.0031$ & $472 \pm 26$ \\
\hline $\begin{array}{c}\text { Ti-12Mo-6Zr- } \\
4 \mathrm{Fe}\end{array}$ & & $97.62 \pm 0.99$ & $0.33 \pm 0.0007$ & $451 \pm 27$ \\
\hline
\end{tabular}

Maximum value of elastic modulus for Ti-12Mo which is 104.89 (approx. $105 \mathrm{GPa}$ ) and minimum value is for Ti-12Mo- $6 \mathrm{Zr}-3 \mathrm{Fe}$ with $1300^{\circ} \mathrm{C}$ which is $95 \mathrm{GPa}$ which is 9.5\% less than Ti-12Mo which is better for biomaterial application. Poisson's coefficient is for all alloys listed above is either 0.33 or 0.34 . 
From the hardness column it is shown that hardness is increasing after addition of $\mathrm{Zr}$ and $\mathrm{Fe} . \%$ increase in hardness is much higher than Ti-Mo binary alloy. Minimum hardness value is for Ti-12Mo which is $283 \mathrm{HV}$ and maximum is for Ti-12Mo-6Zr$1 \mathrm{Fe}$ at $1250^{\circ} \mathrm{C}$ sintering temperature which is $542 \mathrm{HV}$. Value of hardness for Ti$12 \mathrm{Mo}$ is approx. $48 \%$ less than Ti-12Mo-6Zr-1Fe.

So, combination of less elastic modulus and higher hardness is found in case of quaternary alloys as shown in table 4.5 which is better for biomaterial applications.

\subsubsection{Surface fracture characterization}

\subsubsection{Ti-Mo base alloy sintered at $1250{ }^{\circ} \mathrm{C}$}

From the figure 4.1(A), it is confirmed that there is formation of dimple which shows its ductile character but in figure 4.1(D) more brittle surface are seen.
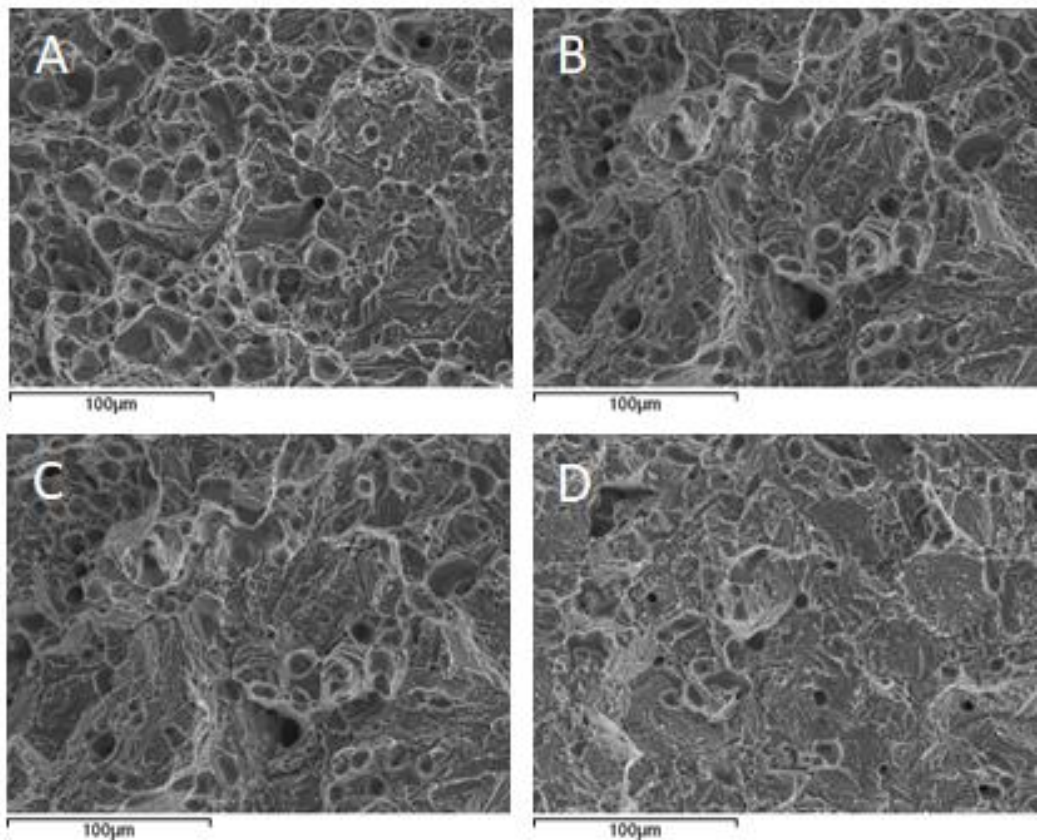

Figure 4.1: Fractography analysis of A) Ti-12Mo B) Ti-15Mo C) Ti-12Mo-6Zr (D) Ti-15Mo-6Zr with 500x magnification 
It is seen the fracture is of mixed type like brittle and ductile for all the alloys. Brittleness is more in case of Ti-15Mo-6Zr which is clearly shown in figure 4.1 (D).

\subsubsection{Fractography analysis of Ti-Mo-Zr-Fe quaternary alloys sintered at 1250 ${ }^{\circ} \mathrm{C}$}

From figure 4.2 (B) it is clearly shown that nature of fracture surface of Ti-12Mo$6 \mathrm{Zr}-2 \mathrm{Fe}$ is mixed type (brittle and ductile) and when $\%$ of $\mathrm{Fe}$ increases brittle nature of alloy increases shown in 4.2 (C) and (D). as it can be seen easily that Ti-12Mo$6 \mathrm{Zr}-4 \mathrm{Fe}$ is a brittle alloy among the quaternary alloys.
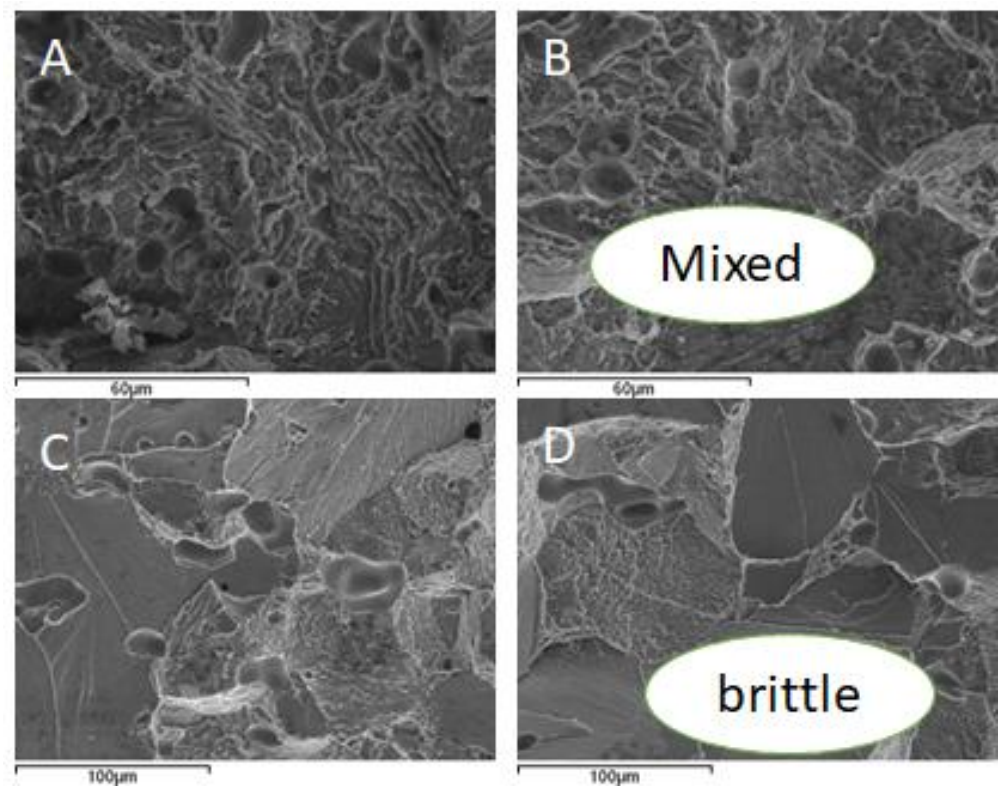

Figure 4.2: Fractography analysis of (A) Ti-12Mo-6Zr-1Fe B) Ti-12Mo-6Zr-2Fe with magnification 250x and (C) Ti-12Mo-6Zr-3Fe (D) Ti-12Mo-6Zr-4Fe with 500x magnification

\subsubsection{Grain size analysis:}

Grain size of Ti-12Mo, Ti-12Mo-6Zr and Ti-12Mo-6Zr-xFe at $1250^{\circ} \mathrm{C}$ are shown in table 4.6. 
Development of new high-performance Titanium alloys with Fe-addition for dental implants

Table 4.6: Grain Size Analysis of Ti-Mo alloy sintered at $1250{ }^{\circ} \mathrm{C}$

\begin{tabular}{|c|c|c|}
\hline Alloys & Grain Size $(\mu \mathrm{m})$ & SD \\
\hline Ti-12Mo & 68 & 9 \\
\hline Ti-12Mo-6Zr & 61 & 5 \\
\hline Ti-12Mo-6Zr-1Fe & 60 & 16 \\
\hline Ti-12Mo-6Zr-2Fe & 80 & 15 \\
\hline Ti-12Mo-6Zr-3Fe & 73 & 4 \\
\hline Ti-12Mo-6Zr-4Fe & 81 & 5 \\
\hline
\end{tabular}

Maximum grain size is calculated for Ti-12Mo-6Zr-4Fe and lowest grain size is for $\mathrm{Ti}-12 \mathrm{Mo}-6 \mathrm{Zr}-1 \mathrm{Fe}$. But normally with addition of $\mathrm{Fe}$, grain size is increased, which is confirmed by table 4.6 .

Grain size of Ti-12Mo is more than Ti-12Mo-6Zr and Ti-12Mo-6Zr-1Fe but lesser than Ti-12Mo-6Zr-2Fe, Ti-12Mo-6Zr-3Fe and Ti-12Mo-6Zr-4Fe; which is clearly shown in figure 4.4 .

Lower grain size after mixing is better for further use and it's recommended by the metallurgist so in our alloy Ti-12Mo-6Zr-1Fe is better option and maximum grain size is for Ti-12Mo-6Zr-4Fe, which is approx. $35 \%$ more in comparison to grain size of Ti-12Mo-6Zr-1Fe.

\subsubsection{Microstructure characterization}

\subsubsection{Ti-Mo base alloys sintered at $1250{ }^{\circ} \mathrm{C}$}

Microstructure of Ti-12Mo, Ti-15Mo, Ti-12Mo-6Zr and Ti-15Mo-6Zr are shown in figure 4.3 , where one can see that grains are of mixed type, as some are very large, and some grains are small. Grain boundaries are clearly shown in microstructure images and there is some black spot found which is porosity found in the sample. 

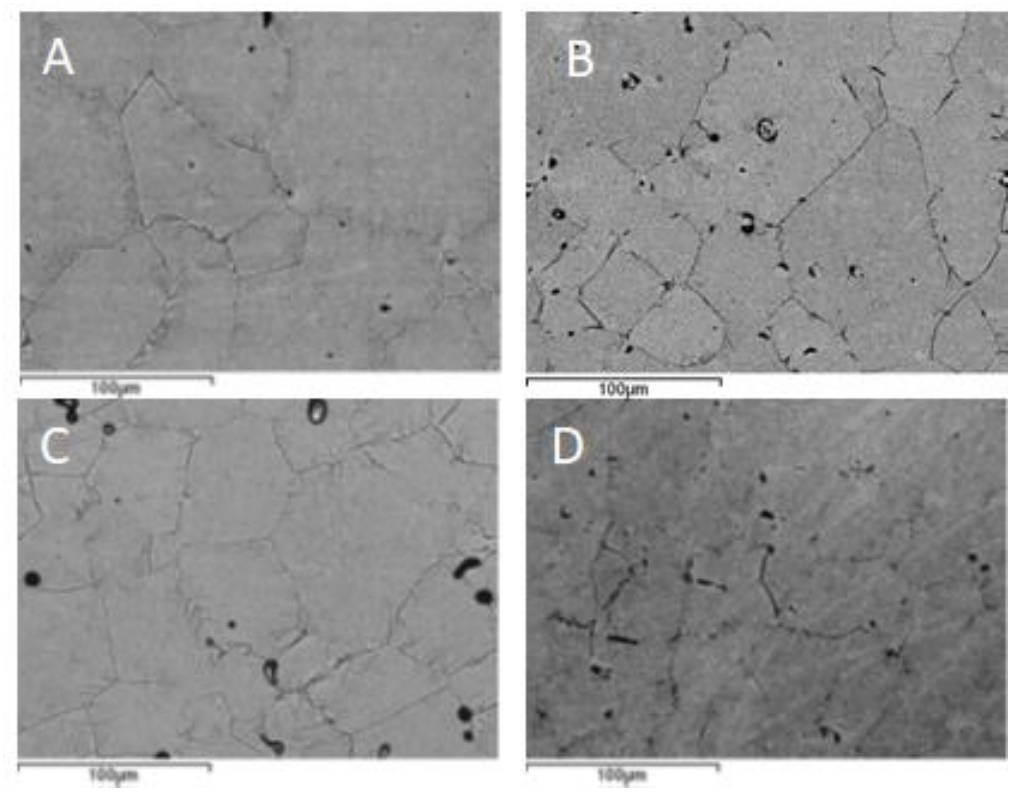

Figure 4.3: Microstructure of Ti-Mo base alloy with magnification 500X BS (a) Ti-12Mo (b)Ti-15Mo (c) $\mathrm{Ti}-12 \mathrm{Mo}-6 \mathrm{Zr}(\mathrm{d}) \mathrm{Ti}-15 \mathrm{Mo}-6 \mathrm{Zr}$

Elemental composition of different Ti-Mo binary alloys was obtained by EDS analysis, which is tabulated in table 4.7 by which we can confirm that mixing of the element is homogeneous as the element mixing \% before sintering and after sintering is almost same which is clearly shown in table 4.7.

Table 4.7: Elemental Composition calculated by smart map analysis

\begin{tabular}{|c|c|c|c|}
\hline Alloys & $\mathrm{Ti}(\% \mathrm{w} / \mathrm{w})$ & $\mathrm{Mo}(\% \mathrm{w} / \mathrm{w})$ & $\mathrm{Zr}(\% \mathrm{w} / \mathrm{w})$ \\
\hline Ti-12Mo & $87.10 \pm 0.18$ & $12.90 \pm 0.12$ & N/A \\
\hline Ti-12Mo-6Zr & $80.73 \pm 0.13$ & $12.84 \pm 0.42$ & $6.43 \pm 0.15$ \\
\hline Ti-15Mo & $85.23 \pm 0.21$ & $14.77 \pm 0.01$ & N/A \\
\hline Ti-15Mo-6Zr & $77.22 \pm 0.18$ & $16.35 \pm 0.23$ & $6.43 \pm 0.02$ \\
\hline
\end{tabular}

\subsubsection{Microstructure analysis of Ti-Mo-Zr-Fe Quaternary alloys sintered at $1250^{\circ} \mathrm{C}$}

Microstructure of Ti-12Mo-6Zr-xFe $(\mathrm{x}=1,2,3,4)$ are shown in figure 5.4. Grains are irregular which means some grains are large and some small which clearly shown in figure 4.4 (A) and 4.4 (B), some smaller and bigger porosity are also found which is shown in figure $4.4(\mathrm{C})$ and $4.4(\mathrm{D})$. 


\section{Development of new high-performance Titanium alloys with Fe-addition for dental implants}
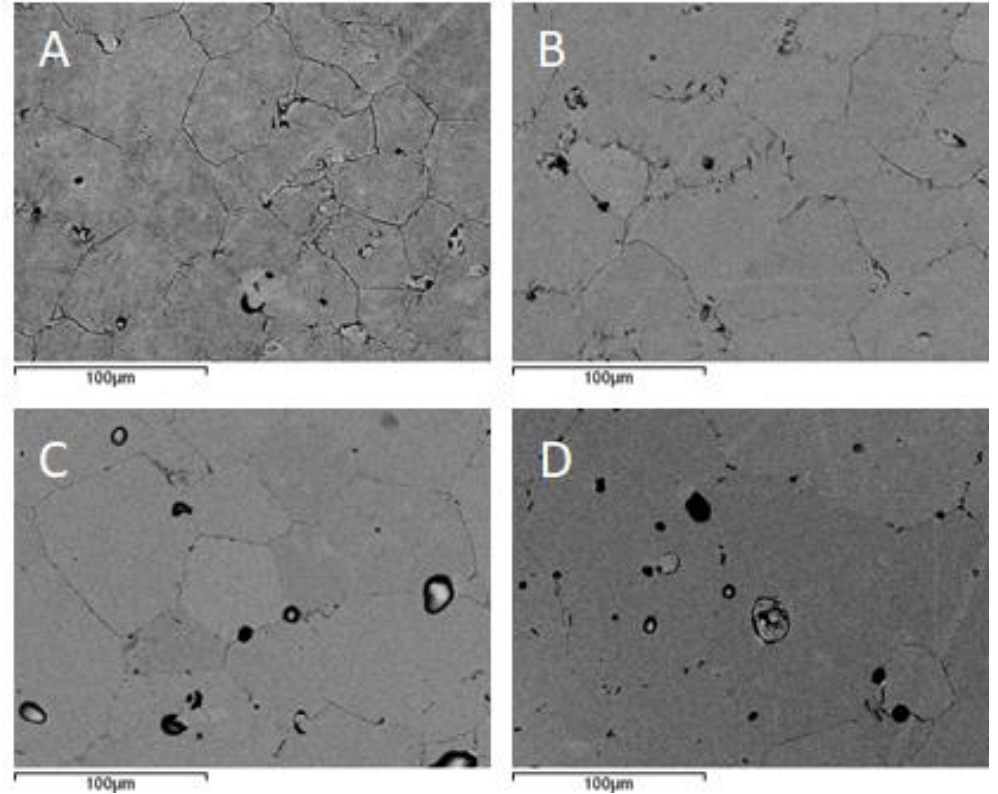

Figure 4.4: Microstructure of Ti-Mo quaternary alloy with magnification 500X BS (A) Ti-12Mo-6Zr-

$1 \mathrm{Fe}(\mathrm{B}) \mathrm{Ti}-12 \mathrm{Mo}-6 \mathrm{Zr}-2 \mathrm{Fe}$ (C) Ti-12Mo-6Zr-3Fe (D) Ti-12Mo-6Zr-4Fe at $1250^{\circ} \mathrm{C}$

Porosity found for Ti-12Mo-6Zr-3Fe and Ti-12Mo-6Zr-4Fe are of both types i.e. open porosity and close porosity which is clearly shown in figure 4.4 (C) and (D).

\subsubsection{EDS analysis of Ti-12Mo-6Zr-2Fe}

From figure 4.5 , it is seen that mixing of elements inside Ti-12Mo-6Zr-2Fe are not homogenous. It may be due to lack of diffusion. 

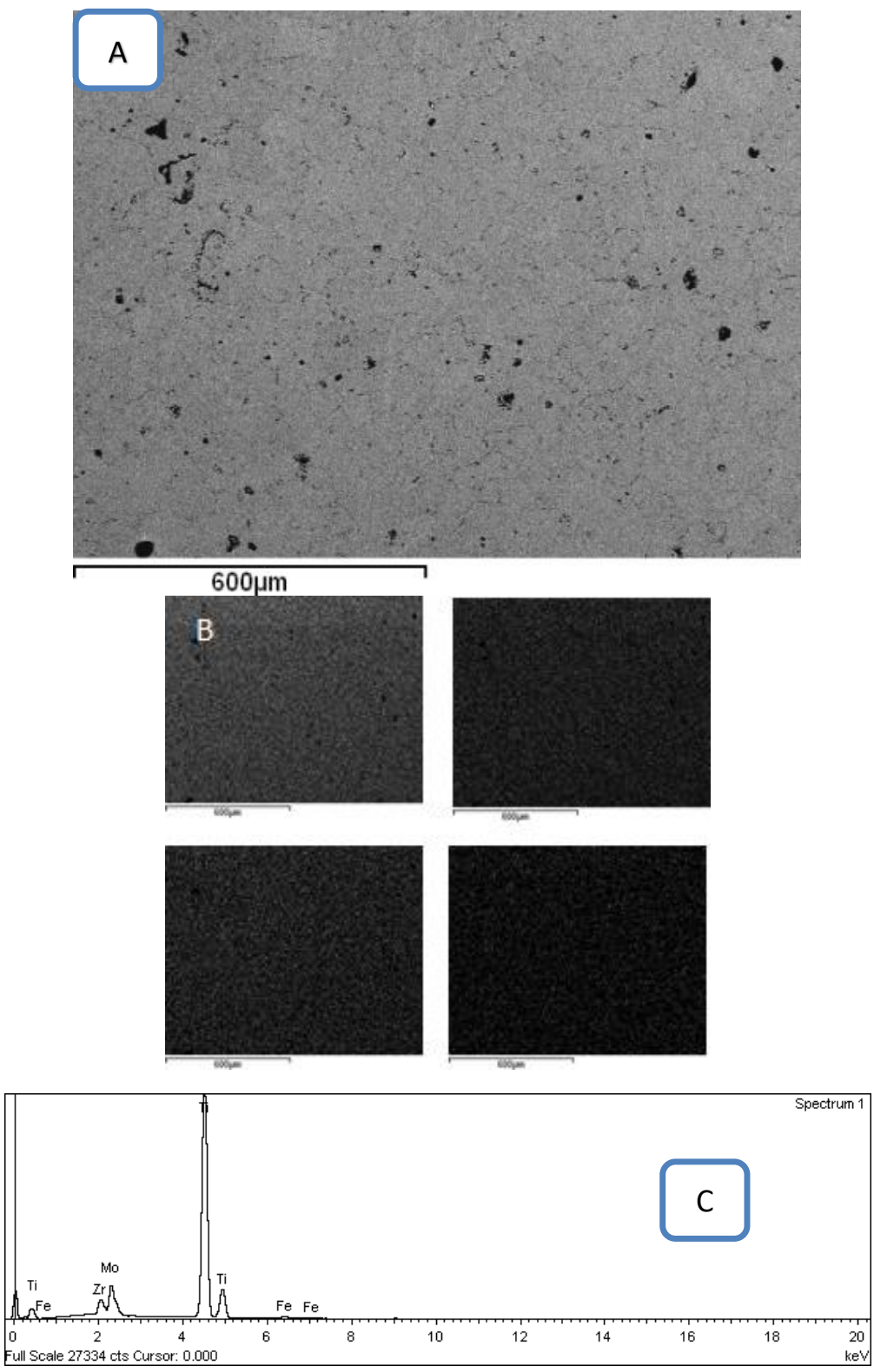

Figure 4.5: Smart map analysis of Ti-12Mo-6Zr-2Fe with 500x BS (A) General mixing of the alloying element (B) map of $\mathrm{Ti}$, Mo K , Zr L and Fe K elemental mixing and (C) Spectrum obtained with EDS analysis 
Elemental composition of different Ti-12Mo-6Zr-xFe $(\mathrm{x}=1,2,3,4)$ are calculated by smart map analysis with SEM images which is shown in table 4.8 . We can easily quantify the percentage of different elements like Ti, Mo, $\mathrm{Zr}$ and Fe after sintering of samples in different quaternary alloys. From the spectrum, it is clearly seen that the curve of $\mathrm{Ti}$ is very high and other elements also appeared like $\mathrm{Mo}, \mathrm{Zr}$ and $\mathrm{Fe}$.

Table 4.8: Elemental Composition calculated by smart map analysis of Ti-12Mo-6Zr-XFe.

\begin{tabular}{|c|c|c|c|c|}
\hline Alloys & Ti (\%w/w) & Mo (\%w/w) & Zr (\%w/w) & Fe (\%w/w) \\
\hline $\begin{array}{c}\text { Ti-12Mo-6Zr- } \\
1 F e\end{array}$ & $79.68 \pm 0.18$ & $12.89 \pm 0.07$ & $6.49 \pm 0.08$ & $0.94 \pm 0.02$ \\
\hline $\begin{array}{c}\text { Ti-12Mo-6Zr- } \\
\text { 2Fe }\end{array}$ & $78.96 \pm 0.48$ & $12.75 \pm 0.42$ & $6.33 \pm 0.13$ & $1.95 \pm 0.06$ \\
\hline $\begin{array}{c}\text { Ti-12Mo-6Zr- } \\
\text { 3Fe }\end{array}$ & $77.70 \pm 0.21$ & $13.04 \pm 0.01$ & $6.43 \pm 0.12$ & $2.84 \pm 0.08$ \\
\hline $\begin{array}{c}\text { Ti-12Mo-6Zr- } \\
4 F e\end{array}$ & $76.47 \pm 0.18$ & $13.18 \pm 0.23$ & $6.46 \pm 0.02$ & $3.9 \pm 0.04$ \\
\hline
\end{tabular}

From the EDS analysis it is clearly shown that the composition after mixing is approx. same as the starting composition of the mixing. For example, Ti-12Mo-6Zr$1 \mathrm{Fe}$ have $79.68 \%$ of $\mathrm{Ti}$ (Starting $81 \%$ approx.), Mo is $12.89 \%$ after sintering (Starting 12\%) and so on.

\subsection{9: XRD Analysis}

$\mathrm{XRD}$ analysis are shown in figure 4.6 which indicates the peaks of $\alpha$ and $\beta$ and by this we can also calculate the $\%$ of both the phases. $\alpha$-phase are denoted by blue line and $\beta$-phase are denoted by red line. 

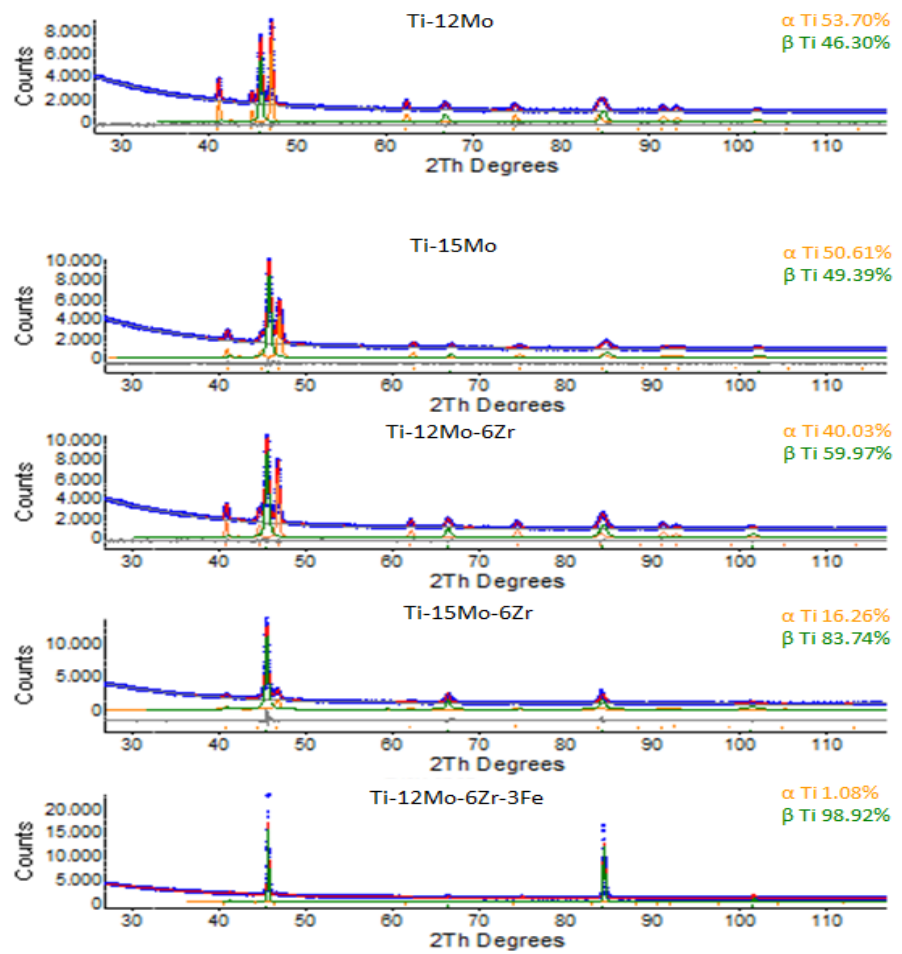

Figure 4.6: Phase analysis by XRD analysis of Ti-Mo alloys sintered at $1250^{\circ} \mathrm{C}$

In table 4.9 we summarized the $\%$ of both the phases calculated with XRD analysis by which we can see than addition of more $\%$ of Mo enhance $\%$ of $\beta$-phase, addition of $\mathrm{Zr}$ also increase the $\%$ of $\beta$ phase as Ti- $12 \mathrm{Mo}-6 \mathrm{Zr}$ have $49.39 \%$ of $\beta$ in comparison to Ti-12Mo and also addition of Fe improves $\beta$-phase as for Ti-12Mo-6Zr-3Fe $\%$ of $\beta$ phase is $98.92 \%$ which is near to $100 \%$.

Table 4.9: Phase analysis by XRD analysis sintered at $1250{ }^{\circ} \mathrm{C}$

\begin{tabular}{|c|c|c|}
\hline Alloy & $\alpha$-phase & $\beta$-phase \\
\hline Ti-12Mo & 53.7 & 46.3 \\
\hline Ti-12Mo-6Zr & 40.03 & 59.97 \\
\hline Ti-15Mo & 50.61 & 49.39 \\
\hline Ti-15Mo-6Zr & 16.26 & 83.74 \\
\hline Ti-12Mo-6Zr-3Fe & 1.08 & 98.92 \\
\hline
\end{tabular}


Ti-12Mo have approx. both $\alpha$-phase and $\beta$-phase almost equal which is clearly tabulated in table 4.9 and addition of $\mathrm{Zr}$ improves $\beta$-phase stability as we can see for Ti-12Mo-6Zr and same in case of Ti-15Mo-6Zr. When we add Fe to Ti-12Mo-6Zr $\beta$-phase stability improves more and it tends to approx. $100 \% \beta$-phase as we can see in table 4.9.

\subsubsection{0: EBSD analysis}

IPF X Color 1
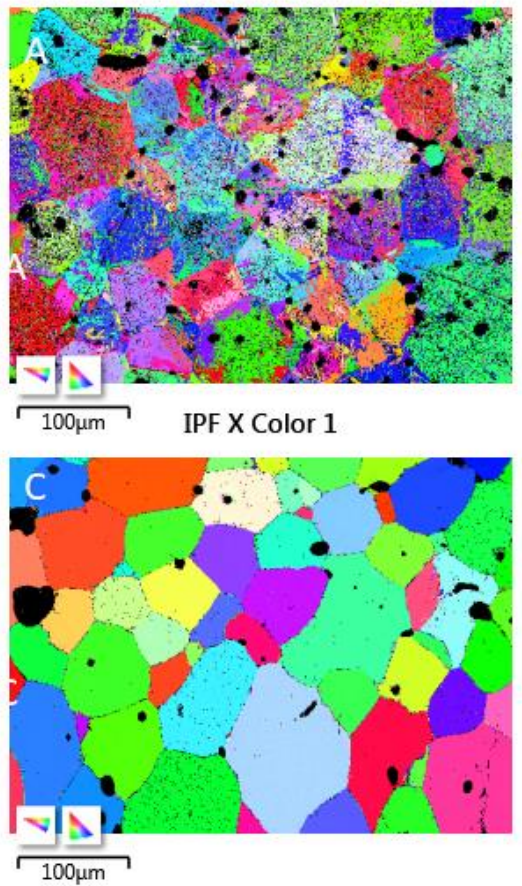

IPF X Color 1
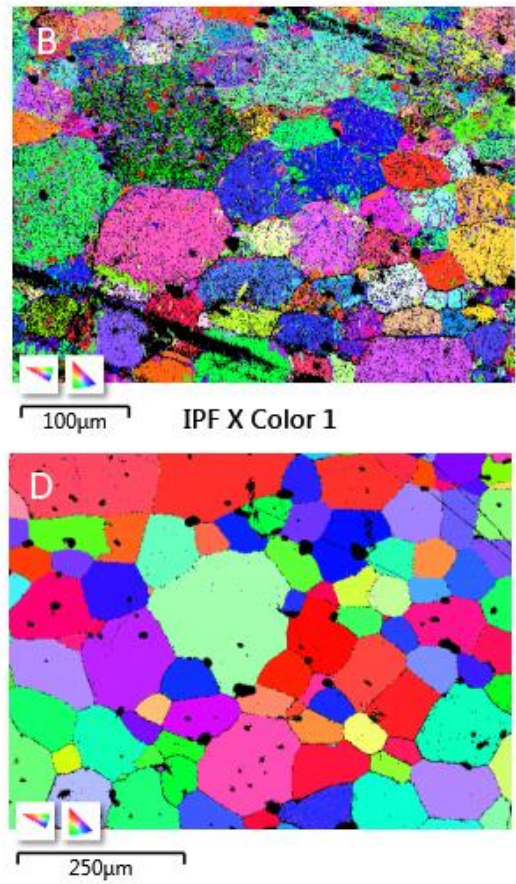

Figure 4.7: IPF X mixed image by EBSD analysis of (A) Ti-12Mo (B) Ti-12Mo-6Zr (C) Ti-12Mo$6 \mathrm{Zr}-3 \mathrm{Fe}$ at $1250^{\circ} \mathrm{C}$ (D) $\mathrm{Ti}-12 \mathrm{Mo}-6 \mathrm{Zr}-3 \mathrm{Fe}$ at $1300^{\circ} \mathrm{C}$

Structure of Ti-12Mo-6Zr-3Fe at both temperatures have more regular grain structure; but found porosity which is black colour in figure 5.7 (C) and (D). 
Phase fraction with EBSD analysis, is summarized in table 4.10; by which we can see the $\%$ of both phase $\alpha$ and $\beta$ without zero solution. Zero solution includes dirt and porosity.

Figure 4.7 shows the IPF $X$ colour of different alloys like Ti-12Mo, Ti-12Mo-6Zr, Ti-12Mo-6Zr-3Fe at $1250^{\circ} \mathrm{C}$, Ti- $12 \mathrm{Mo}-6 \mathrm{Zr}-3 \mathrm{Fe}$ at $1300{ }^{\circ} \mathrm{C}$ which shows the grain structure of the alloys. There are difficulties in preparation of samples, due to lots of dirt appeared in the structure. $\%$ of $\beta$ for Ti-12Mo-6Zr-3Fe with both temperatures is approx. $100 \%$, which signifies that addition of Fe increases the $\%$ of $\beta$.

Table 4.10: Phase fraction for different alloys with EB

\begin{tabular}{|l|l|l|l|}
\hline Alloys & \% Ti $\boldsymbol{\alpha}$ & \% Ti $\boldsymbol{\beta}$ & $\begin{array}{l}\text { \% Ti } \beta \text { with } \\
\text { XRD }\end{array}$ \\
\hline Ti-12Mo & 41.25 & 58.75 & 46.3 \\
\hline Ti-12Mo-6Zr & 29.75 & 70.25 & 59.97 \\
\hline $\begin{array}{l}\text { Ti-12Mo-6Zr- } \\
\text { 3Fe @ 1250C }\end{array}$ & 0.96 & 99.04 & 98.92 \\
\hline $\begin{array}{l}\text { Ti-12Mo-6Zr- } \\
\text { 3Fe @ 1300 }\end{array}$ & 0.24 & 99.76 & NA \\
\hline
\end{tabular}

\subsection{Mechanical Alloying (MA):}

We have work with MA for better homogenity and for this we have to explore with different combination of parameters for betterment of our alloys.

\subsection{1: MA for Ti-12Mo-6Zr-2Fe with different compaction pressure}

\subsubsection{Mechanical properties with short milling time}

Total porosity is found by Archimedes's test. In table 5.11, relative sintered density by mechanical alloying (MA) at $600 \mathrm{MPa}$ is less than $900 \mathrm{MPa}$. This is starting of the compaction pressure with $600 \mathrm{MPa}$ and then for improvement the mechanical properties we have to increase the compaction pressure to $900 \mathrm{MPa}$ for further analysis. When total porosity is very high in case of $600 \mathrm{MPa}$, it results in reducing the total porosity and increasing compaction pressure 50\%. When compaction pressure increases from $600 \mathrm{MPa}$ to $900 \mathrm{MPa}$ for MA method, in this case porosity decreases $6 \%$ approx. Total porosity also affects the strength, if total porosity is high than strength is less and vice versa. 
Development of new high-performance Titanium alloys with Fe-addition for dental implants

Table 4.11 Relative density of Ti-12Mo-6Zr-2Fe with different conditions

\begin{tabular}{|c|c|c|}
\hline Alloy & Relative sintered Density & Flexural strength (MPa) \\
\hline Ti-12Mo-6Zr-2Fe MA @ 600 MPa & $84.17 \pm 0.82$ & $329 \pm 7$ \\
\hline Ti-12Mo-6Zr-2Fe MA @ 900 MPa & $89.83 \pm 0.43$ & $637 \pm 13$ \\
\hline
\end{tabular}

An increase in compaction pressure (from $600 \mathrm{MPa}$ to $900 \mathrm{MPa}$ ) also enhances the bending strength from $329 \mathrm{MPa}$ to $637 \mathrm{MPa}$ (approx 95\%), which is denoted in table 4.11 .

Elastic modulus is the main mechanical property for designing biomaterials. Table 4.12 shows the elastic modulus found by Ultrasonic test of Ti-12Mo-6Zr-2Fe with $\mathrm{MA}$ at $600 \mathrm{MPa}$ and $900 \mathrm{MPa}$ compaction pressure. Modulus of elasticity is determined with MA at $600 \mathrm{MPa}$ giving least value and better option as biomaterial.

Table 4.12 Elastic modulus of Ti-12Mo-6Zr-2Fe with different conditions

\begin{tabular}{|c|c|c|}
\hline Alloys & Avg. E(Gpa) & Avg.v \\
\hline Ti-12Mo-6Zr-2Fe MA @ 600 MPa & $66.34 \pm 10.00$ & $0.300 \pm 0.042$ \\
\hline Ti-12Mo-6Zr-2Fe MA @900 MPa & $81.98 \pm 2.43$ & $0.320 \pm 0.011$ \\
\hline
\end{tabular}

\subsubsection{Fractography analysis}
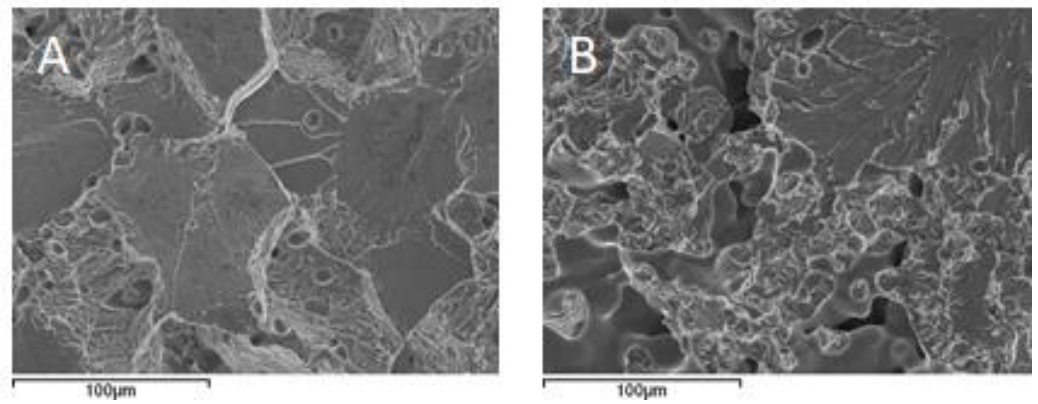

Figure.4.8: Fractrography image of Ti-12Mo-6Zr-2Fe (A) with MA method under $900 \mathrm{MPa}$ compaction pressure (B) with EB method under $600 \mathrm{MPa}$ compaction pressure

Fracture surface with EB have more ductile nature in comparison to MA which is clearly shown in figure 4.8. Figure 4.8 (A) have brittle surface and 4.8 (B) have dimple formation, which shows ductile character for EB alloys. 


\subsubsection{Micro-Structural analysis}

From the figure 4.9, it is seen that the microstructure of Ti-12Mo-6Zr-2Fe prepared by MA method at $600 \mathrm{MPa}$, bigger porosity appears due to plastic deformation occurs in MA. While increasing pressure for MA method, then pore size gets decreased, but number of grain boundary upturns.
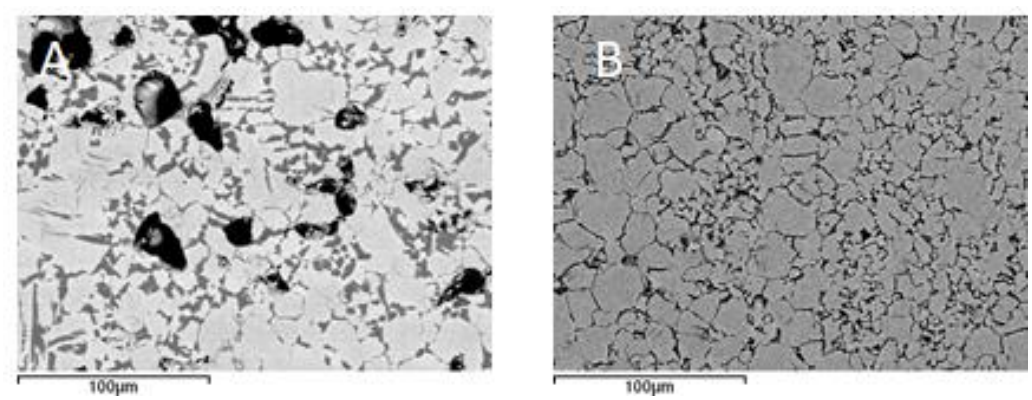

Figure 4.9: Microstruture of Ti-12Mo-6Zr-2Fe: Mechanical alloying method with (A) $600 \mathrm{MPa}$ compaction pressure and (B) with $900 \mathrm{MPa}$ compaction pressure

The porosity of the samples and the percentage of phases were obtained from images taken by optical microscopy using an image analysis program (See Table 4.13). EB samples show less porosity than MA samples. It is shown that MA with $900 \mathrm{MPa}$ have less internal porosity and more $\beta$-phase in comparison to sample prepared with $600 \mathrm{MPa}$.

Table 4.13: Phase distribution and internal porosity

\begin{tabular}{|c|c|c|c|c|}
\hline Process & Alloy & \% Internal Porosity & \multicolumn{2}{|c|}{ Phases Distribution by XRD } \\
\% Alpha & Beta \\
\hline MA_600 MPa & $\begin{array}{c}\text { Ti-12Mo-6Zr- } \\
\text { 2Fe }\end{array}$ & $21.43 \pm 3.38$ & $24.13 \pm 2.29$ & $75.87 \pm 2.29$ \\
\hline MA_900 MPa & $\begin{array}{c}\text { Ti-12Mo-6Zr- } \\
\text { 2Fe }\end{array}$ & $9.86 \pm 2.61$ & $16.17 \pm 1.81$ & $83.83 \pm 1.81$ \\
\hline
\end{tabular}


Development of new high-performance Titanium alloys with Fe-addition for dental implants

\subsubsection{EBSD analysis of Ti-12Mo-6Zr-2Fe with MA at $900 \mathrm{MPa}$}

Figure 4.10 shows the IPF $X$ and phase color of Ti-12Mo-6Zr-2Fe with MA at 900 $\mathrm{MPa}$, due to more porosity and dirt; grain boundary is not visible.
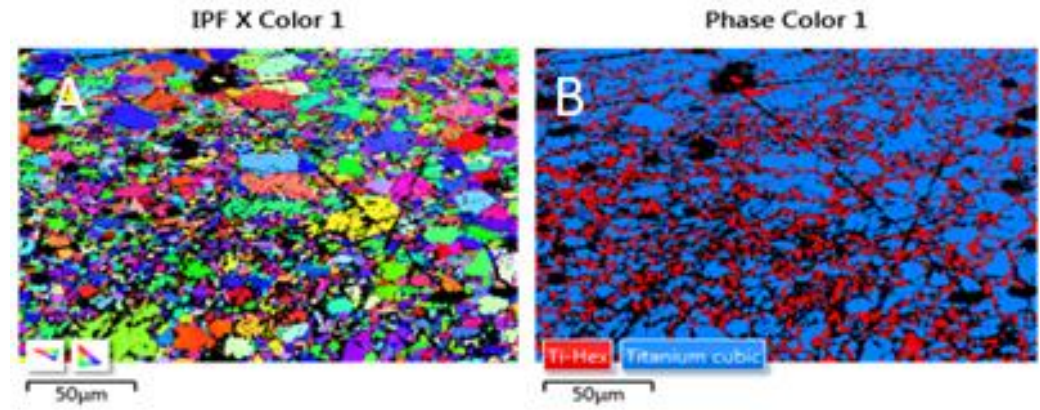

Figure 4.10: (A) IPF X color image and (B) phase color of Ti-12Mo-6Zr-2Fe with MA at $900 \mathrm{MPa}$

Table 4.14: Phases analysis with EBSD for Ti-12Mo-6Zr-2Fe with MA at $900 \mathrm{MPa}$

\begin{tabular}{|c|c|}
\hline Phase Name & Phase Fraction (\%) \\
\hline$\alpha-\mathrm{Ti}$ & 21.23 \\
\hline$\beta-\mathrm{Ti}$ & 50.14 \\
\hline Zero Solutions & 28.63 \\
\hline
\end{tabular}

\subsubsection{MA with short milling time}

This stage is for betterment or improvement of the property than before. Different parameters (exploring different milling speed and different milling time) are explored. One binary alloy and quaternary alloy (Ti-15Mo and Ti-15Mo-6Zr-2Fe) are chosen. For Mechanical Alloying, it is intended to know powder characteristics after mixing like fluidity, granulometric analysis and powder cut.

\subsubsection{Fluidity test:}

Fluidity test results for Ti-Mo alloy with different combinations of milling speed and miling time are listed in table 4.15, where on can see fluidity with milling speed 180 RPM and milling time $52 \mathrm{~min}$. for Ti-15Mo are highest in all the combination and for Ti-15Mo-6Zr-2Fe also too. 
Table 4.15: Fluidity (For Ti-15Mo and Ti-15Mo-6Zr-2Fe) with different milling condition

\begin{tabular}{|c|c|c|c|c|}
\hline Alloy & $\begin{array}{l}\text { rpm- } \\
\text { Time } \\
\text { (min) }\end{array}$ & $\begin{array}{l}\text { Powder } \\
\text { Wt (gr) }\end{array}$ & $\begin{array}{l}\text { Time for Fluid } \\
\text { meter }(S)\end{array}$ & Fluidity \\
\hline \multirow[t]{8}{*}{ Ti-15Mo } & 300_45 & 23.701 & 21 & 1.13 \\
\hline & 300_37 & 21.219 & 19 & 1.12 \\
\hline & 300_52 & 21.957 & 20 & 1.10 \\
\hline & $240 \_45$ & 17.275 & 16 & 1.08 \\
\hline & $180 \_45$ & 23.814 & & Not possible \\
\hline & $180 \_52$ & 24.616 & 21 & 1.17 \\
\hline & $240 \_52$ & 21.499 & 21 & 1.02 \\
\hline & 180_60 & 24.427 & 4.5 (with bigger one) & 5.43 \\
\hline \multirow[t]{3}{*}{ Ti-15Mo-6Zr-2Fe } & $180 \_45$ & 23.492 & & Not possible \\
\hline & $180 \_52$ & 24.112 & 19 & 1.27 \\
\hline & 210_45 & 23.982 & & Not possible \\
\hline
\end{tabular}

These binary alloy and quaternary alloy with different milling speed and milling time are explored. Fluidity is determined with fluid meter. The best flow of powder is for $240 \mathrm{rpm}-52 \mathrm{~min}$ for both alloys. Some powder is very sticky like elemental blend powders (like powders with $180 \mathrm{rpm}-45 \mathrm{~min}$ ), in which determination of fluidity is not possible for both alloys. Some powders get welded with each other, for which fluidity is not able to be checked with Hall fluid meter. Hence, overall fluidity is measurable for some combination of parameters (300-37, 300-45, 300-52 and 180$52)$.

\subsubsection{Granulometry:}

Granulometry results for Ti-15Mo MA (with different parameters) and for Ti-15Mo6Zr-2Fe (MA with different parameters) are shown in table 4.16. 
Table 4.16: Particle size analysis (For Ti-15Mo and Ti-15Mo-6Zr-2Fe) with different milling conditions

\begin{tabular}{|c|c|c|c|c|}
\hline Alloy & $\begin{array}{c}\text { Condition }(\mathrm{rpm}- \\
\mathrm{min})\end{array}$ & $\mathrm{D}(0.1)(\mu \mathrm{m})$ & $\mathrm{D}(0.5)(\mu \mathrm{m})$ & $\mathrm{D}(0.9)(\mu \mathrm{m})$ \\
\hline Ti-15Mo & $300-37$ & 194 & 368 & 621 \\
\hline & $300-45$ & 33 & 74 & 294 \\
\hline & $300-52$ & 221 & 316 & 450 \\
\hline & $180-45$ & 11 & 32 & 85 \\
\hline & $180-52$ & 26 & 138 & 524 \\
\hline & $180-60$ & 47 & 283 & 582 \\
\hline & $240-45$ & 111 & 338 & 600 \\
\hline & $240-52$ & 232 & 384 & 614 \\
\hline Ti-15Mo-6Zr-2Fe & $180-45$ & 16 & 43 & 202 \\
\hline & $180-52$ & 20 & 49 & 306 \\
\hline & $210-45$ & 26 & 54 & 145 \\
\hline
\end{tabular}

Graph obtained from granulometry for different combination of milling speed and milling time are shown in figure 4.11. Maximum particle size obtained is for Ti$15 \mathrm{Mo}$ with $300 \mathrm{rpm}-52 \mathrm{~min}$; zf stands for Ti-15Mo-6Zr-2Fe. Graph shows D (0.1), $\mathrm{D}(0.5), \mathrm{D}(0.9)$. With the same parameter of milling time and milling time Ti-15Mo have larger grains in comparison to Ti-15Mo-6Zr-2Fe which seen in table 4.16. 


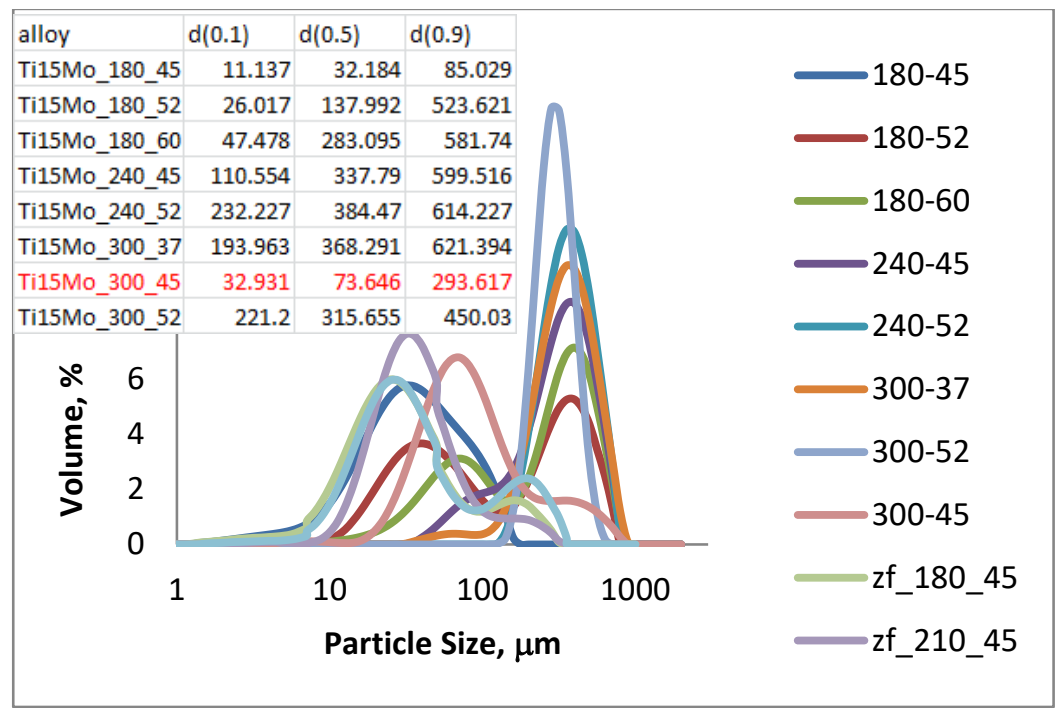

Figure 4.11: Granulometry for Ti-15Mo and Ti-15Mo-6Zr-2Fe (MA, P \& S)

\subsubsection{Mechanical properties:}

Table 4.17: Green density (\%), sintered density (\%) and bending strength of (For Ti-15Mo and Ti$15 \mathrm{Mo}-6 \mathrm{Zr}-2 \mathrm{Fe}$ ) with different milling conditions

\begin{tabular}{|c|c|c|c|c|}
\hline Alloy & Condition & $\begin{array}{c}\text { Green density } \\
(\%)\end{array}$ & $\begin{array}{c}\text { Sintered density } \\
(\%)\end{array}$ & $\begin{array}{c}\text { Bending strength } \\
(\mathrm{MPa})\end{array}$ \\
\hline \multirow{5}{*}{ Ti-15Mo } & $300-45$ & $76.36 \pm 0.55$ & $90.55 \pm 0.91$ & $604.67 \pm 143.22$ \\
\cline { 2 - 5 } & $300-37$ & $74.94 \pm 0.1$ & $85.78 \pm 0.32$ & $410.28 \pm 43.93$ \\
\cline { 2 - 5 } & $300-52$ & $75.8 \pm 0.67$ & $82.36 \pm 0.88$ & $371.72 \pm 61.50$ \\
\cline { 2 - 5 } & $180-45$ & $78.58 \pm 0.58$ & $86.64 \pm 0.23$ & $1597.74 \pm 179.47$ \\
\cline { 2 - 5 } & $180-52$ & $78.38 \pm 0.59$ & $97.81 \pm 0.45$ & $1261.08 \pm 79.07$ \\
\cline { 2 - 5 } & $180-60$ & $77.1 \pm 0.59$ & $95.91 \pm 95.91$ & $1062.51 \pm 274.08$ \\
\cline { 2 - 5 } & $240-45$ & $74.66 \pm 0.6$ & $85.49 \pm 1.4$ & $400.01 \pm 41.38$ \\
\hline \multirow{3}{*}{ Ti-15Mo-6Zr- } & $240-52$ & $76.14 \pm 0.88$ & $92.44 \pm 0.69$ & $525.09 \pm 91.07$ \\
\cline { 2 - 5 } $2 \mathrm{Fe}$ & $180-45$ & $78.12 \pm 0.45$ & $98.97 \pm 0.53$ & $431.85 \pm 119.50$ \\
\cline { 2 - 5 } & $210-45$ & $77.55 \pm 0.6$ & $95.92 \pm 0.66$ & $427.56 \pm 57.57$ \\
\cline { 2 - 5 } & $180-52$ & $78.24 \pm 0.17$ & $98.79 \pm 0.16$ & $667.63 \pm 57.04$ \\
\hline
\end{tabular}

Green density, sintered density and bending strength for Ti-15Mo and Ti-15Mo-6Zr$2 \mathrm{Fe}$ are enlisted in table 4.17 . From this table, we can say that this property is better 
in case of $180 \mathrm{rpm}-52 \mathrm{~min}$ as we can see that sintered density is $97.81 \%$ and flexural strength is also higher with this. For Ti-15Mo-6Zr-2Fe also, with $180 \mathrm{rpm}-52 \mathrm{~min}$, sintered density is higher and bending strength are also high. So, for further research we will use this parameter.

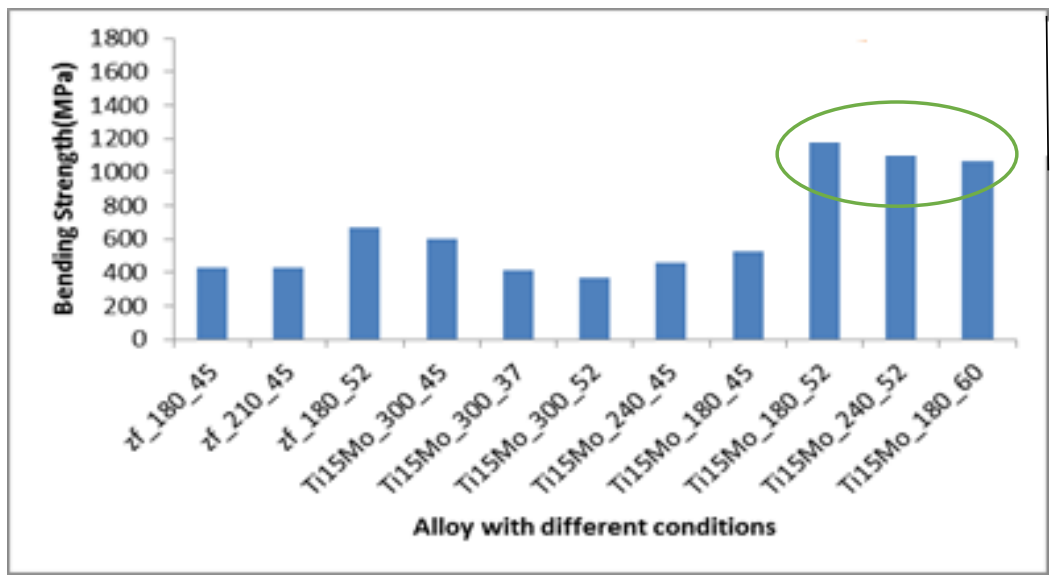

Figure 4.12: Bending strength of Ti-15Mo with different combination of parameters

Here zf stands for Ti-15Mo-6Zr-2Fe. Maximum bending strength is for Ti-15Mo (with $180 \mathrm{rpm}$ and $45 \mathrm{~min}$ ) and the value noted is $1597 \mathrm{MPa}$ which is confirmed by figure 4.12.

Table 4.18: Elastic modulus (GPa) (For Ti-15Mo) with different milling conditions

\begin{tabular}{|l|l|l|l|}
\hline Alloys & Condition & $\begin{array}{l}\text { Elastic modulus } \\
(\mathrm{GPa})\end{array}$ & $\mathrm{v}$ \\
\hline \multirow{5}{*}{ Ti-15Mo } & $300-45$ & $81.34 \pm 6.55$ & $0.29 \pm 0.035$ \\
\cline { 2 - 4 } & $300-37$ & $63.69 \pm 3.70$ & $0.3 \pm 0.007$ \\
\cline { 2 - 4 } & $300-52$ & $62.90 \pm 2.78$ & $0.31 \pm 0.041$ \\
\cline { 2 - 4 } & $240-45$ & $63.57 \pm 1.60$ & $0.32 \pm 0.098$ \\
\cline { 2 - 4 } & $180-45$ & $75.61 \pm 3.00$ & $0.37 \pm 0.008$ \\
\cline { 2 - 4 } & $180-52$ & $101.22 \pm 1.06$ & $0.32 \pm 0.038$ \\
\cline { 2 - 4 } & $240-52$ & $73.53 \pm 1.65$ & $0.37 \pm 0.004$ \\
\cline { 2 - 4 } Ti-15Mo-6Zr-2Fe & $180-60$ & $94.5 \pm 0.17$ & $0.33 \pm 0.003$ \\
\cline { 2 - 4 } & $180-45$ & $76.89 \pm 4.15$ & $0.35 \pm 0.089$ \\
\cline { 2 - 4 } & $210-45$ & $83.43 \pm 1.67$ & $0.34 \pm 0.056$ \\
\hline & $180-52$ & $98.75 \pm 2.34$ & $0.31 \pm 0.063$ \\
\hline
\end{tabular}


For this experiment, binary alloy Ti-15Mo with more variation of parameters is started and followed by quaternary alloy Ti-15Mo-6Zr-2Fe with less variation than before. The value of bending strength for Ti-15Mo-6Zr-2Fe is very less in comparison to Ti-15Mo; which is shown in figure 4.12.

Elastic modulus of Ti-15Mo with different milling conditions are listed in table 4.18. The value of elastic modulus with milling time 300 RPM and 52 Min. are the lowest but porosity is highest (table 4.17) and bending strength is lower.

\subsection{3: Mechanical alloying with $180 \mathrm{rpm}-52 \mathrm{~min}$. for different alloys}

\section{Granulometry Analysis:}

Particle size with granulometry test are tabulated in table 4.19; by where one can see the values of $\mathrm{D}(0.1)(\mu \mathrm{m}), \mathrm{D}(0.5)(\mu \mathrm{m})$ and $\mathrm{D}(0.9)(\mu \mathrm{m})$.

Table 4.19: Particle size analysis of Ti-Mo with 180 RPM-52 Minutes

\begin{tabular}{|l|c|c|c|c|}
\hline \multicolumn{1}{|c|}{ Alloy } & rpm-min & $\mathrm{D}(0.1)(\mu \mathrm{m})$ & $\mathrm{D}(0.5)(\mu \mathrm{m})$ & $\mathrm{D}(0.9)(\mu \mathrm{m})$ \\
\hline Ti-12Mo & $180-52$ & 18.623 & 47.734 & 121.112 \\
\hline Ti-12Mo-6Zr & $180-52$ & 19.183 & 49.997 & 135.366 \\
\hline Ti-15Mo-6Zr & $180-52$ & 20.975 & 52.942 & 146.499 \\
\hline Ti-15Mo-6Zr-4Fe & $180-52$ & 27.193 & 72.947 & 273.247 \\
\hline
\end{tabular}

Unimodal characteristics for all alloys are found representing that mixing of powders are very homogeneous and belongs to one proper region.

\section{Green Density (\%), Sintered density and bending strength:}

Green density, sintered density and bending strength of different Ti-Mo alloys are listed in table 4.20. Maximum bending strength obtained for Ti-12Mo which is 1292.31 MPa and least obtained for Ti-15Mo-6Zr-4Fe which is $476.28 \mathrm{MPa}$.

Table 4.20: Green density, sintered density and bending strength of Ti-Mo with 180 rpm-52 min

\begin{tabular}{|l|l|l|l|}
\hline Alloy & Green density $(\%)$ & Sintered density $(\%)$ & $\begin{array}{c}\text { Bending Strength } \\
(\mathrm{MPa})\end{array}$ \\
\hline Ti-12Mo & $78.92 \pm 3.86$ & $94.32 \pm 0.93$ & $1292.31 \pm 57.59$ \\
\hline Ti-12Mo-6Zr & $74.79 \pm 3.03$ & $96.30 \pm 0.05$ & $1127.15 \pm 240.47$ \\
\hline Ti-15Mo-6Zr & $77.51 \pm 1.22$ & $96.48 \pm 0.38$ & $1169.65 \pm 82.87$ \\
\hline Ti-15Mo-6Zr-4Fe & $76.53 \pm 1.07$ & $98.19 \pm 0.05$ & $476.28 \pm 32.45$ \\
\hline
\end{tabular}


Sintered density or porosity with Archimedes' test method is analysed. Porosity is directly related to bending strength and microstructure. If porosity is very low, then bending strength and microstructure seems to be better. Here, for Ti-15Mo-6Zr-2Fe these properties are better than another alloy.

\section{Ultrasonic and hardness test:}

Elastic modulus and hardness result for different Ti-Mo alloys with milling parameters $180 \mathrm{rpm}-52 \mathrm{~min}$ is listed in table 4.21 . The least value for elastic modulus obtained for Ti-12Mo-6Zr is $83.40 \mathrm{GPa}$. Hardness value is approx. $180 \mathrm{HV}$ for all alloys.

Table 4.21: Elastic modulus of Ti-Mo with 180 RPM-52 Minutes

\begin{tabular}{|c|c|c|c|}
\hline Alloys & E (GPa) & Average v & Hardness (HV) \\
\hline Ti-12Mo & $95.48 \pm 3.38$ & $0.3300 \pm 0.0130$ & $182.2 \pm 7.9$ \\
\hline Ti-12Mo-6Zr & $83.40 \pm 3.32$ & $0.3700 \pm 0.0095$ & $183.8 \pm 11.6$ \\
\hline Ti-15Mo-6Zr & $94.87 \pm 2.96$ & $0.3400 \pm 0.0088$ & $180.6 \pm 24.4$ \\
\hline Ti-15Mo-6Zr-4Fe & $101.27 \pm 0.86$ & $0.3400 \pm 0.0016$ & $183.6 \pm 19.1$ \\
\hline
\end{tabular}

\subsection{4: Mechanical alloying with Process control agent (PCA):}

After work with different combination with short milling time and without PCA for Ti-Mo alloys, we have found lots of heat in the milling jar. So, for minimizing the heat we must work with PCA. In this stage of experiment, process control agent (PCA- Stearic acid (1\% by mass) is employed for controlling the heat generation.

\section{Powder utility:}

This is calculated by the ratio of powder obtained after milling and weight of initial powder. From the table 4.22, it is evident that final weight of powder/ initial weight of powder is very less in case of $24 \mathrm{~h}$ milling time. Milling time is to be changed to obtain more powder after milling. 
Table 4.22: Powder utility (\%) of Ti-15Mo-6Zr-2Fe with $1 \%$ PCA

\begin{tabular}{|c|c|c|c|c|}
\hline Condition & Initial powder weight $(\mathrm{g})$ & Final powder weight $(\mathrm{g})$ & Ratio & $\%$ \\
\hline 6h-5 mm Dia. & 49.77 & 44.10 & 0.89 & 88.61 \\
\hline 6h-10mm Dia & 49.77 & 39.38 & 0.79 & 79.12 \\
\hline 24h-5 mm Dia & 24.88 & 5.70 & 0.23 & 22.91 \\
\hline 24h-10 mm Dia & 24.88 & 6.40 & 0.26 & 25.72 \\
\hline
\end{tabular}

\section{Fluidity test:}

Fluidity test was done after the mixing of powder which is shown in table 4.23. The maximum value obtained for Ti-15Mo-6Zr-2Fe with $6 \mathrm{~h}-10 \mathrm{~mm}$ Dia. is maximum which is 1.575 .

Table 4.23: Fluidity of Ti-15Mo-6Zr-2Fe with $1 \%$ PCA

\begin{tabular}{|c|c|c|c|}
\hline Condition & Final weight $(\mathrm{g})$ & Time elapsed $(\mathrm{S})$ & Fluidity $(\mathrm{g} / \mathrm{s})$ \\
\hline 6 h-5 mm dia. & 44.1 & 32 & 1.378 \\
\hline $6 \mathrm{~h}-10 \mathrm{~mm}$ dia. & 39.38 & 25 & 1.575 \\
\hline $24 \mathrm{~h}-5 \mathrm{~mm}$ dia. & 5.7 & 5 & 1.14 \\
\hline $24 \mathrm{~h}-10 \mathrm{~mm}$ dia. & 6.4 & $\begin{array}{c}\text { Not possible (particles } \\
\text { are not regular) }\end{array}$ & - \\
\hline
\end{tabular}

\section{Granulometry test:}

Granulometry test done after the mixing of powder which is shown in table 4.24.

Table 4.24: Particle size analysis of Ti-15Mo-6Zr-2Fe with $1 \%$ PCA

\begin{tabular}{|c|c|c|c|}
\hline Condition & $\mathrm{D}(0.1) \mu \mathrm{m}$ & $\mathrm{D}(0.5) \mu \mathrm{m}$ & $\mathrm{D}(0.9) \mu \mathrm{m}$ \\
\hline $6 \mathrm{~h}-5 \mathrm{~mm}$ & 20.082 & 45.838 & 101.190 \\
\hline $6 \mathrm{~h}-10 \mathrm{~mm}$ & 28.679 & 69.643 & 204.169 \\
\hline $24 \mathrm{~h}-5 \mathrm{~mm}$ & 317.879 & 489.91 & 751.404 \\
\hline $24 \mathrm{~h}-10 \mathrm{~mm}$ & 37.611 & 70.993 & 141.315 \\
\hline
\end{tabular}

From the granulometry test table, the biggest particle size obtained was subjected to condition $24 \mathrm{~h}-5 \mathrm{~mm}$. This is due to large time and with high impact for long time with $5 \mathrm{~mm}$ ball size. 


\section{Development of new high-performance Titanium alloys with Fe-addition for dental implants}

\section{SEM analysis of milling powder (after milling):}

From figure 4.13 we can see the powder cut characteristics after milling. Powders got agglomerated with each other's and forms bigger particle size, which is clearly shown by the figure. With the higher milling time $(24 \mathrm{~h})$ particle size gets bigger due to more agglomeration which is clearly seen in figure 4.13 (C) and 4.13 (D).
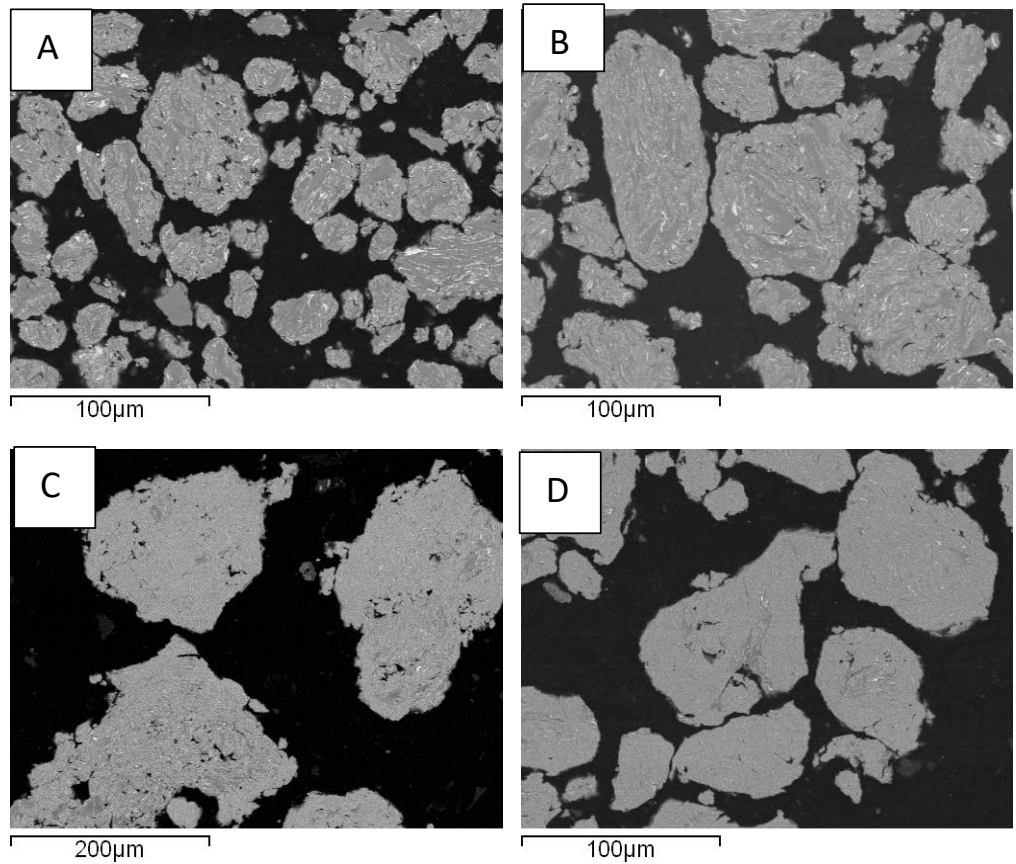

Figure 4.13: SEM analysis of mechanical alloying powder with (a) $6 \mathrm{~h}-5 \mathrm{~mm}$ (b) $6 \mathrm{~h}-10 \mathrm{~mm}$ (c) $24 \mathrm{~h}-5$ $\mathrm{mm}(\mathrm{d}) 24 \mathrm{~h}-10 \mathrm{~mm}$

After SEM of powder cut of the milled powder, we have done elemental analysis with help of Energy dispersive X-ray spectroscopy (EDS) tool, which is tabulated in table 4.25.

Table 4.25: Elemental analysis of Ti-15Mo-6Zr-2Fe with $1 \%$ PCA by SEM image

\begin{tabular}{|c|c|c|c|c|}
\hline Condition & Ti K (\%w/w) & Fe K (\%w/w) & Zr L (\%w/w) & Mo L (\%w/w) \\
\hline $6 \mathrm{~h}-5 \mathrm{~mm}$ & 78.43 & 1.33 & 6.39 & 13.85 \\
\hline $6 \mathrm{~h}-10 \mathrm{~mm}$ & 79.30 & 1.35 & 5.94 & 7.4 \\
\hline $24 \mathrm{~h}-5 \mathrm{~mm}$ & 75.11 & 2.15 & 6.95 & 15.78 \\
\hline $24 \mathrm{~h}-10 \mathrm{~mm}$ & 75.00 & 1.86 & 16.46 & 9.30 \\
\hline
\end{tabular}




\section{Mechanical Test result of sintered part:}

We worked with different milling time and different ball size with process control agent (PCA), but powder weight obtained after milling with $24 \mathrm{~h}$ was very less in both ball size (5 $\mathrm{mm}$ and $10 \mathrm{~mm}$ ) Diameter, so it's difficult to make sintered samples with $24 \mathrm{~h}$. So, we worked with $6 \mathrm{~h}$ with both ball size $(5 \mathrm{~mm}$ and $10 \mathrm{~mm}$ ) Diameter. We worked with 5 samples with milling time of $6 \mathrm{~h}$ and milling ball size of $5 \mathrm{~mm}$ diameter and 4 samples with milling time of $6 \mathrm{~h}$ and milling ball size of $5 \mathrm{~mm}$ (which depends on powder obtained after milling). Bending strength tests were possible for only $6 \mathrm{~h}$ conditions with both ball sizes $5-$ and $10-\mathrm{mm}$. Mechanical properties are tabulated in table 4.26 which includes sintered density, bending strength, elastic modulus and eccentricity of the sintered samples.

Table 4.26: Mechanical properties of sintered Ti-15Mo-6Zr-2Fe with 1\% PCA by SEM image

\begin{tabular}{|c|c|c|c|c|}
\hline Condition & Sintered density & $\begin{array}{c}\text { Bending } \\
\text { strength (MPa) }\end{array}$ & $\begin{array}{c}\text { Elastic modulus } \\
(\mathrm{GPa})\end{array}$ & 0 \\
\hline $6 \mathrm{H}-5 \mathrm{~mm}$ & $95.61 \pm 0.43$ & 309.66 & $100.36 \pm 5.74$ & $0.3230 \pm 0.0029$ \\
\hline $6 \mathrm{H}-10 \mathrm{~mm}$ & $87.31 \pm 0.71$ & 576.29 & $89.32 \pm 0.85$ & $0.3001 \pm 0.0061$ \\
\hline
\end{tabular}

\section{3: Spark Plasma Sintering (SPS) Results:}

For obtaining full density alloy, SPS is a better technology for enhancement of its density. After analysing microstructure, it is confirmed that alloys produced from SPS technology have full density. But the flexural strength is very low for ternary alloy and quaternary alloys. Process could have been improved for better results. We have mixed powder for SPS alloy with milling condition $180 \mathrm{rpm}-52$ min without PCA. For each alloy sintering temperatures are $1100^{\circ} \mathrm{C}$.

\subsection{1: Mechanical test result:}

For getting the mechanical properties, we have done different mechanical test like sintered density, bending strength, elastic modulus test which is tabulated in table 4.27. Relative density is approx. $100 \%$ with each condition for different alloys. Bending strength is maximum for Ti- $15 \mathrm{Mo}$ with $1150^{\circ} \mathrm{C}$ which is $1006.66 \mathrm{MPa}$; for ternary and quaternary alloys bending strength is much lower than binary alloys as clearly shown in table 4.27 . Elastic modulus is minimum for Ti-15Mo with $1100{ }^{\circ} \mathrm{C}$ which is $88.24 \mathrm{GPa}$. 
Development of new high-performance Titanium alloys with Fe-addition for dental implants

Table 4.27: Different mechanical test of Ti-Mo alloys by SPS with different temperatures

\begin{tabular}{|l|l|l|l|l|}
\hline \multirow{2}{*}{ Alloys } & $\begin{array}{l}\text { Temperature } \\
\left({ }^{\circ} \mathrm{C}\right)\end{array}$ & $\begin{array}{l}\text { Relative } \\
\text { Density }(\%)\end{array}$ & $\begin{array}{l}\text { Bending Strength } \\
(\mathrm{MPa})\end{array}$ & $\begin{array}{l}\text { Elastic } \\
\text { modulus }(\mathrm{GPa})\end{array}$ \\
\hline \multirow{3}{*}{ Ti-15Mo } & 1100 & 97.64 & 921.08 & 88.24 \\
\cline { 2 - 5 } & 1150 & 98.28 & 1006.66 & 98.02 \\
\cline { 2 - 5 } & 1200 & 98.25 & 863.09 & 97.50 \\
\hline \multirow{3}{*}{ Ti-15Mo-6Zr } & 1100 & 97.99 & 378.64 & 95.35 \\
\cline { 2 - 5 } & 1150 & 98.32 & 409.16 & 97.64 \\
\cline { 2 - 5 } & 1200 & 98.57 & 414.07 & 92.75 \\
\hline \multirow{2}{*}{\begin{tabular}{l} 
Ti-15Mo-6Zr- \\
\cline { 2 - 5 }
\end{tabular}} & 1100 & 97.72 & 339.34 & 106.08 \\
\cline { 2 - 5 } & 1150 & 97.24 & 335.93 & 101.15 \\
\cline { 2 - 5 } & 1200 & 97.16 & 301.89 & 103.87 \\
\hline
\end{tabular}

\subsection{2: Microhardness of Ti-Mo alloys with different conditions:}

Table 4.28: Micro hardness of Ti-Mo alloys by SPS with different temperatures

\begin{tabular}{|l|l|l|}
\hline Alloys & Temperature $\left({ }^{\circ} \mathrm{C}\right)$ & Microhardness (HV) \\
\hline \multirow{4}{*}{ Ti-15Mo } & 1100 & $275 \pm 48$ \\
\cline { 2 - 3 } & 1150 & $350 \pm 50$ \\
\cline { 2 - 3 } Ti-15Mo-6Zr & 1200 & $334 \pm 25$ \\
\hline \multirow{4}{*}{ Ti-15Mo-6Zr-2Fe } & 1100 & $377 \pm 23$ \\
\cline { 2 - 3 } & 1150 & $401 \pm 26$ \\
\cline { 2 - 3 } & 1200 & $452 \pm 31$ \\
\hline & 1100 & $465 \pm 41$ \\
\cline { 2 - 3 } & 1150 & $469 \pm 48$ \\
\cline { 2 - 3 } & 1200 & \\
\hline
\end{tabular}

Microhardness of Ti-Mo alloys are shown in table 4.28; the value of microhardness for Ti-15Mo-6Zr-2Fe sintered at $1150{ }^{\circ} \mathrm{C}$ is maximum among all which value is 477 
$\mathrm{HV}$ and minimum is for Ti-15Mo at sintering temperature of $1100^{\circ} \mathrm{C}$ which is 275 HV.

\subsection{3: DRX analysis of SPS samples with different conditions}
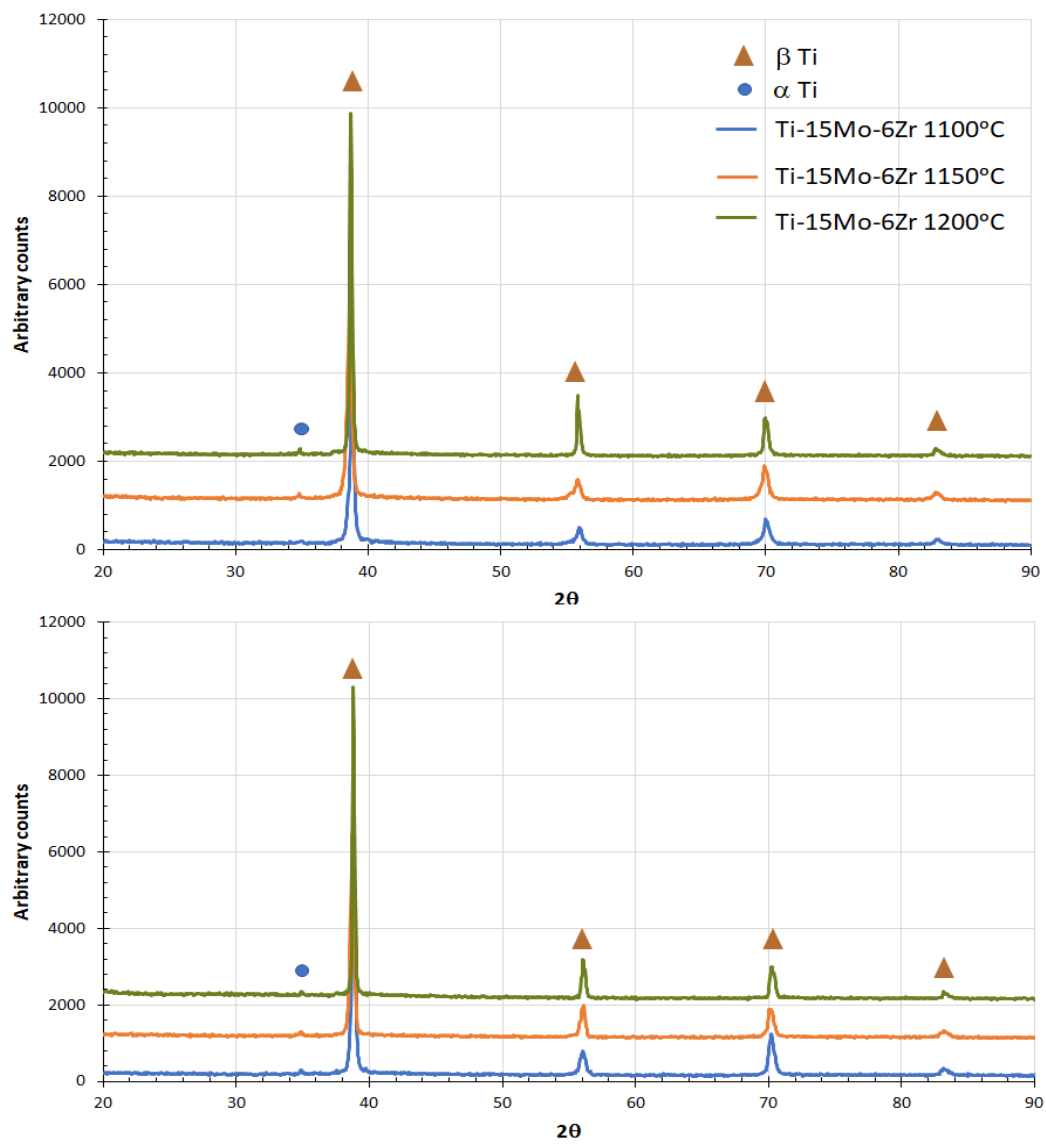

Figure 4.14: DRX analysis of Ti-Mo SPS samples with different Temperature (a) of Ti-15Mo-6Zr (b)

$$
\text { Ti-15Mo-6Zr-2Fe }
$$

DRX analysis done for Ti-Mo alloys by SPS with different sintering temperature is shown in figure 4.14. Ti- beta and Ti-alpha are found in the DRX analysis, highest peaks are obtained for beta-phase. 


\subsection{4: EBSD analysis of Ti-Mo alloys by SPS with different conditions:}

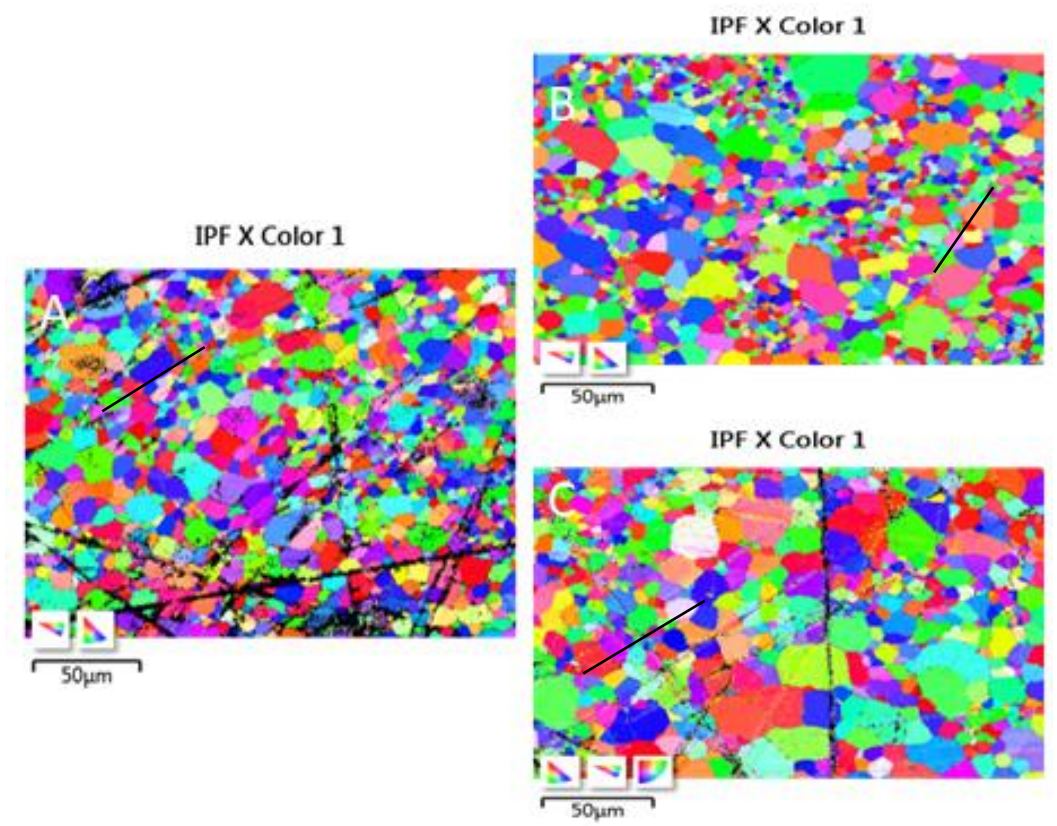

Figure 4.15: IPF X analysis of SPS samples (A) Ti-15Mo with $1100^{\circ} \mathrm{C}$ (B) Ti-15Mo-6Zr-2Fe with $1100^{\circ} \mathrm{C}(\mathrm{C}) \mathrm{Ti}-15 \mathrm{Mo}-6 \mathrm{Zr}-2 \mathrm{Fe}$ with $1200^{\circ} \mathrm{C}$

IPF $\mathrm{X}$ analysis of different Ti-Mo alloys prepared with SPS method are shown in figure 4.15 . We analysed with Ti-15Mo sintered at $1100^{\circ} \mathrm{C}$, Ti-15Mo-6Zr-2Fe with $1100^{\circ} \mathrm{C}$ and $\mathrm{Ti}-15 \mathrm{Mo}-6 \mathrm{Zr}-2 \mathrm{Fe}$ sintered at $1200^{\circ} \mathrm{C}$. Black line is due to dirt in the sample (preparation is difficult). Agglomeration activity found in these samples which is clearly shown in figure 4.15 .

Phase fraction for SPS samples obtained from EBSD analysis is shown in table 4.29. $\beta \%$ for each condition is the highest, which is approx. $98 \%$ but for Ti- $15 \mathrm{Mo}-6 \mathrm{Zr}$ sintered at $1200{ }^{\circ} \mathrm{C}$ is 89.32 which is lowest $\beta \%$. For some alloys we have also find $\alpha$ " phase like for Ti- $15 \mathrm{Mo}-6 \mathrm{Zr}$ sintered at $1200^{\circ} \mathrm{C}$ and for Ti-15Mo- $6 \mathrm{Zr}-2 \mathrm{Fe}$ sintered at $1200{ }^{\circ} \mathrm{C}$.

Phase fraction for different samples with method obtained from EBSD analysis is summarized in table 4.29. From table it is found that binary alloys have $\alpha$ and $\beta$ phase and for quaternary alloys have almost $\beta$-phase. 
Table 4.29: Phase analysis table of Ti-Mo alloys with different parameters

\begin{tabular}{|c|c|c|c|}
\hline Alloys & \% Ti $\boldsymbol{\alpha}$ phase & \% Ti $\boldsymbol{\beta}$ phase & \% Ti $\boldsymbol{\alpha}$ \\
\hline Ti-12Mo EB & 41.25 & 58.75 & 0.00 \\
\hline Ti-12Mo-6Zr EB & 27.67 & 72.33 & 0.00 \\
\hline Ti-12Mo-6Zr-2Fe MA & 29.75 & 70.25 & 0.00 \\
\hline Ti-12Mo-6Zr-3Fe EB $1300^{\circ} \mathrm{C}$ & 0.24 & 99.76 & 0.00 \\
\hline Ti-12Mo-6Zr-3Fe EB $1250^{\circ} \mathrm{C}$ & 0.96 & 99.04 & 0.00 \\
\hline Ti-15Mo SPS $1100{ }^{\circ} \mathrm{C}$ & 2.19 & 97.81 & 0.00 \\
\hline Ti-15Mo SPS $1150{ }^{\circ} \mathrm{C}$ & 0.82 & 99.18 & 0.00 \\
\hline Ti-15Mo SPS $1200{ }^{\circ} \mathrm{C}$ & 2.69 & 97.31 & 0.00 \\
\hline Ti-15Mo-6Zr SPS $1100{ }^{\circ} \mathrm{C}$ & 0.96 & 99.04 & 0.00 \\
\hline Ti-15Mo-6Zr SPS $1200{ }^{\circ} \mathrm{C}$ & 0.11 & 89.32 & 10.57 \\
\hline Ti-15Mo-6Zr-2Fe SPS $1100{ }^{\circ} \mathrm{C}$ & 0.05 & 99.95 & 0.00 \\
\hline Ti-15Mo-6Zr-2Fe SPS $1200{ }^{\circ} \mathrm{C}$ & 0.06 & 94.19 & 5.75 \\
\hline
\end{tabular}

Table 4.30: Grain size with EBSD table of Ti-Mo alloys with different parameters

\begin{tabular}{|c|c|c|c|}
\hline Alloys & $\boldsymbol{\alpha}$ phase $(\boldsymbol{\mu m})$ & $\boldsymbol{\beta}$ phase $(\boldsymbol{\mu m})$ & Overall $(\boldsymbol{\mu m})$ \\
\hline Ti-12Mo EB & 6.21 & 7.47 & 6.85 \\
\hline Ti-12Mo-6Zr EB & 4.97 & 6.59 & 6.89 \\
\hline Ti-12Mo-6Zr-2Fe MA & 3.38 & 4.97 & 4.25 \\
\hline Ti-12Mo-6Zr-3Fe EB $1300^{\circ} \mathrm{C}$ & - & 8.46 & 8.46 \\
\hline Ti-12Mo-6Zr-3Fe EB $1250^{\circ} \mathrm{C}$ & - & 9.98 & 9.98 \\
\hline Ti-15Mo SPS $1100^{\circ} \mathrm{C}$ & 2.89 & 4.92 & 4.88 \\
\hline Ti-15Mo SPS $1150{ }^{\circ} \mathrm{C}$ & 2.08 & 5.47 & 5.46 \\
\hline Ti-15Mo SPS $1200{ }^{\circ} \mathrm{C}$ & 2.86 & 5.77 & 5.72 \\
\hline Ti-15Mo-6Zr SPS $1100{ }^{\circ} \mathrm{C}$ & 2.32 & 4.58 & 4.57 \\
\hline Ti-15Mo-6Zr SPS $1200{ }^{\circ} \mathrm{C}$ & - & 5.38 & 5.38 \\
\hline Ti-15Mo-6Zr-2Fe SPS $1100^{\circ} \mathrm{C}$ & - & 4.66 & 4.66 \\
\hline Ti-15Mo-6Zr-2Fe SPS $1200{ }^{\circ} \mathrm{C}$ & - & 6.8 & 6.8 \\
\hline
\end{tabular}

For Ti-12Mo-6Zr-3Fe with $1250^{\circ} \mathrm{C}$ and $1300^{\circ} \mathrm{C}$ have 99.04 and $99.75 \% \beta$-phase, which is almost $100 \%$. SPS improves $\beta$-phase which shown in table 4.29. 
Grain size of alloys with different process and other parameters are tabulated in table 5.30. Mostly binary alloys have both $\alpha$ and $\beta$ grains but for quaternary alloys; only have $\beta$ grains. Size is bigger for $\beta$ grains normally for binary alloys which can see by table 5.30. Grains are normally in range of (6-8) $\mu \mathrm{m}$. Biggest grain is for Ti$12 \mathrm{Mo}-6 \mathrm{Zr}-3 \mathrm{Fe}$ with $\mathrm{EB}$ sintered at $1300{ }^{\circ} \mathrm{C}$ which value is $9.98 \mu \mathrm{m}$. Normally EB have larger grain with respect to MA and SPS process.

\subsection{Corrosion Test:}

From the corrosion we have calculated $\mathrm{I}_{\text {corr }}\left(\mathrm{A} / \mathrm{cm}^{2}\right), \mathrm{E}_{\mathrm{corr}}(\mathrm{V}), \beta \mathrm{c}(\mathrm{V} / \mathrm{dec}), \beta \mathrm{a}(\mathrm{V} / \mathrm{dec})$, OCP $(\mathrm{V}), \mathrm{Rp}\left(\mathrm{k} \Omega . \mathrm{cm}^{2}\right)$ and $\mathrm{V}_{\text {corr }}(\mu \mathrm{m} / \mathrm{year})$ which is tabulated in 4.31 and 4.32 .

Table 4.31: Corrosion result with different parameters $\mathrm{I}_{\mathrm{corr}}\left(\mathrm{A} / \mathrm{cm}^{2}\right), \mathrm{E}_{\mathrm{corr}}(\mathrm{V}), \beta \mathrm{c}(\mathrm{V} / \mathrm{dec})$ and $\beta \mathrm{a}$ $(\mathrm{V} / \mathrm{dec})$ for different process

\begin{tabular}{|c|c|c|c|c|}
\hline Sample & $\mathrm{I}_{\text {corr }}\left(\mathrm{A} / \mathrm{cm}^{2}\right)$ & $\mathrm{E}_{\text {corr }}(\mathrm{V})$ & $\beta \mathrm{c}(\mathrm{V} / \mathrm{dec})$ & $\beta \mathrm{a}(\mathrm{V} / \mathrm{dec})$ \\
\hline Ti-12Mo-6Zr-2Fe MA 600 & $1.49 \mathrm{E}-06$ & -0.42 & 0.104 & 0.133 \\
\hline Ti-12Mo-6Zr-2Fe MA 900 & $2.25 \mathrm{E}-07$ & -0.40 & 0.102 & 0.135 \\
\hline Ti-12Mo-6Zr-1Fe EB 1250 & $1.87 \mathrm{E}-07$ & -0.38 & 0.138 & 0.100 \\
\hline Ti-12Mo-6Zr-2Fe EB 1250 & $2.36 \mathrm{E}-08$ & -0.23 & 0.136 & 0.105 \\
\hline Ti-12Mo-6Zr-3Fe EB 1250 & $1.28 \mathrm{E}-07$ & -0.35 & 0.117 & 0.116 \\
\hline Ti-12Mo-6Zr-4Fe EB 1250 & $1.71 \mathrm{E}-08$ & -0.11 & 0.128 & 0.107 \\
\hline Ti-12Mo-6Zr-1Fe EB 1300 & $2.63 \mathrm{E}-07$ & -0.32 & 0.119 & 0.114 \\
\hline Ti-12Mo-6Zr-2Fe EB 1300 & $1.80 \mathrm{E}-07$ & -0.31 & 0.119 & 0.114 \\
\hline Ti-12Mo-6Zr-3Fe EB 1300 & $1.04 \mathrm{E}-07$ & -0.23 & 0.128 & 0.107 \\
\hline Ti-12Mo-6Zr-4Fe EB 1300 & $1.21 \mathrm{E}-07$ & -0.35 & 0.139 & 0.100 \\
\hline Ti-15Mo 180-52_MA & $1.72 \mathrm{E}-07$ & -0.30 & 0.121 & 0.112 \\
\hline Ti-15Mo-6Zr-2Fe 180-52 & $1.82 \mathrm{E}-07$ & -0.34 & 0.116 & 0.116 \\
\hline Ti-15Mo-6Zr-2Fe 6h+5mm & $2.08 \mathrm{E}-07$ & -0.28 & 0.114 & 0.119 \\
\hline Ti-15Mo-6Zr-2Fe 6h+10mm & $4.08 \mathrm{E}-06$ & -0.59 & 0.108 & 0.126 \\
\hline Ti-15Mo SPS-1150 & $2.61 \mathrm{E}-08$ & -0.30 & 0.128 & 0.106 \\
\hline Ti-15Mo-6Zr-SPS-1150 & $2.15 \mathrm{E}-08$ & -0.13 & 0.132 & 0.104 \\
\hline Ti15Mo6Zr2Fe-SPS-1150 & $2.82 \mathrm{E}-08$ & -0.19 & 0.134 & 0.103 \\
\hline
\end{tabular}

$\mathrm{I}_{\text {corr }}$ value is minimum in case of SPS process which is better for biomaterials. $\mathrm{E}_{\text {corr }}$ and Open circuit potential is more with SPS process which also tabulated in 4.31 and 4.32. $\mathrm{R}_{\mathrm{p}}\left(\mathrm{k} \Omega . \mathrm{cm}^{2}\right)$ is also maximum for SPS process which is better. 
Table 4.32: Corrosion result with different parameters OCP $(\mathrm{V}), \mathrm{R}_{\mathrm{p}}(\mathrm{KW} . \mathrm{cm} 2)$ and $\mathrm{V}_{\text {corr }}(\mu \mathrm{m} / \mathrm{year})$ for different process

\begin{tabular}{|c|c|c|c|}
\hline Sample & OCP $(\mathrm{V})$ & $\mathrm{R}_{\mathrm{p}}\left(\mathrm{k} \Omega . \mathrm{cm}^{2}\right)$ & $\mathrm{V}_{\text {corr }}(\mu \mathrm{m} / \mathrm{year})$ \\
\hline Ti-12Mo-6Zr-2Fe MA 600 & -0.19 & 16932 & 12 \\
\hline Ti-12Mo-6Zr-2Fe MA 900 & -0.32 & 112353 & 1.9 \\
\hline Ti-12Mo-6Zr-1Fe EB 1250 & -0.37 & 135042 & 1.4 \\
\hline Ti-12Mo-6Zr-2Fe EB 1250 & -0.24 & $1.13 \mathrm{E}+06$ & 0.18 \\
\hline Ti-12Mo-6Zr-3Fe EB 1250 & -0.34 & 196827 & 0.99 \\
\hline Ti-12Mo-6Zr-4Fe EB 1250 & -0.18 & $1.48 \mathrm{E}+06$ & 0.13 \\
\hline Ti-12Mo-6Zr-1Fe EB 1300 & -0.32 & 96128 & 2 \\
\hline Ti-12Mo-6Zr-2Fe EB 1300 & -0.30 & 140355 & 1.4 \\
\hline Ti-12Mo-6Zr-3Fe EB 1300 & -0.26 & 243887 & 0.8 \\
\hline Ti-12Mo-6Zr-4Fe EB 1300 & -0.34 & 209075 & 0.93 \\
\hline Ti-15Mo 180-52 MA & -0.31 & 146771 & 1.3 \\
\hline Ti-15Mo-6Zr-2Fe 180-52 & -0.34 & 139179 & 1.4 \\
\hline Ti-15Mo-6Zr-2Fe 6h+5mm & -0.25 & 121412 & 1.7 \\
\hline Ti-15Mo-6Zr-2Fe 6h+10mm & -0.40 & 6194 & 32 \\
\hline Ti-15Mo-SPS-1150 & -0.39 & 966998 & 0.2 \\
\hline Ti-15Mo-6Zr-SPS-1150 & -0.14 & 1175912 & 0.17 \\
\hline Ti-15Mo-6Zr-2Fe-SPS-1150 & -0.27 & 894550 & 0.22 \\
\hline
\end{tabular}

Corrosion test result for Mechanical alloying samples with PCA and without PCA. Current density is lower with Ti-15Mo-6Zr-2Fe in comparison to Ti-15Mo as shown in figure 4.16(A) which we shown in the format of $\log (\mathrm{i}) \mathrm{vs}$ E. Process control agent (PCA) results shown in figure 4.17(A) and (B) which have inferior results in comparison to alloys without PCA. 


\section{Development of new high-performance Titanium alloys with Fe-addition for dental implants}
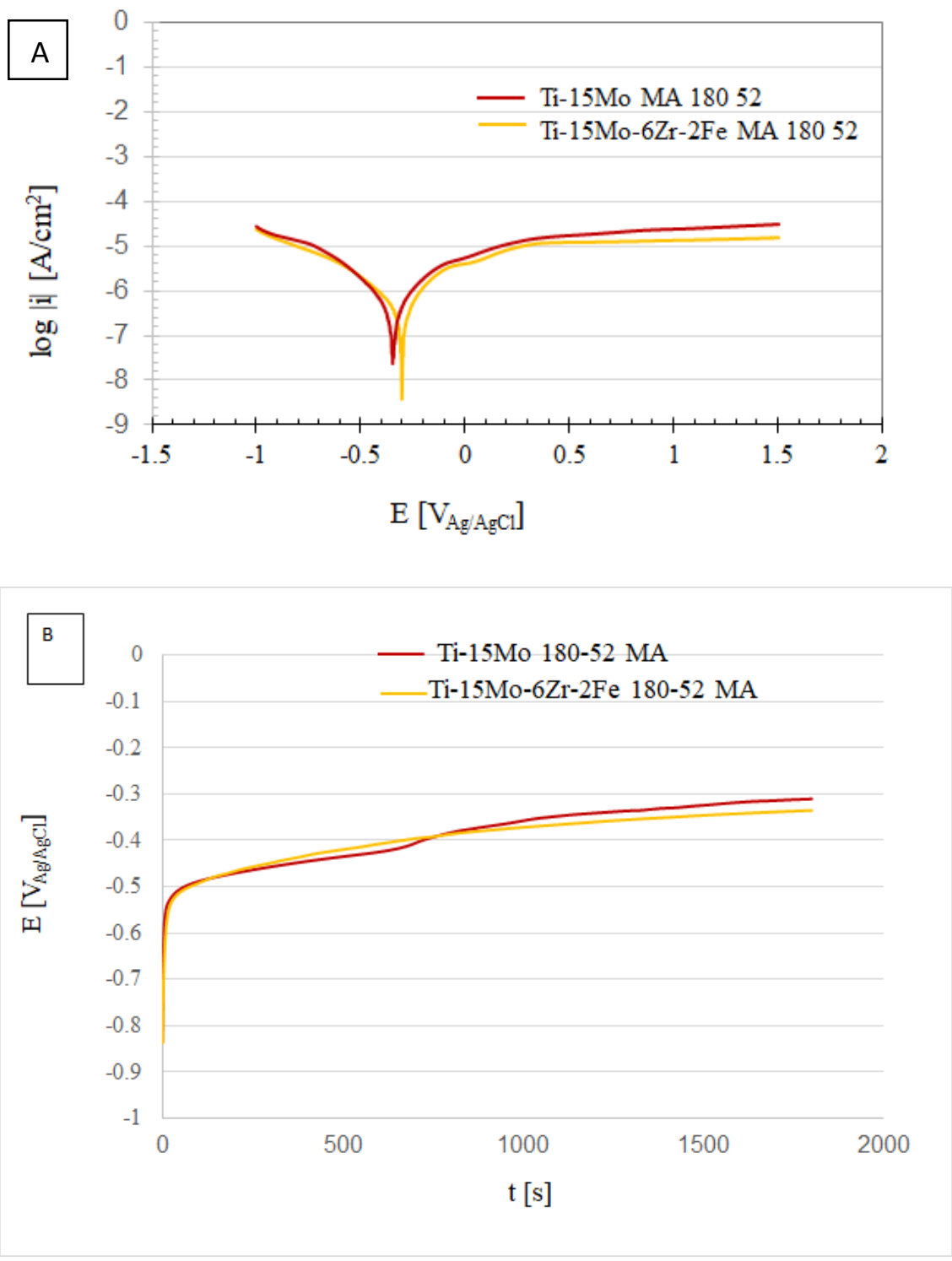

Figure 4.16: Different graphs for corrosion results of MA samples (A) $\log (\mathrm{i})$ vs $\mathrm{E}$ for samples without PCA (B) E vs t for samples without PCA 

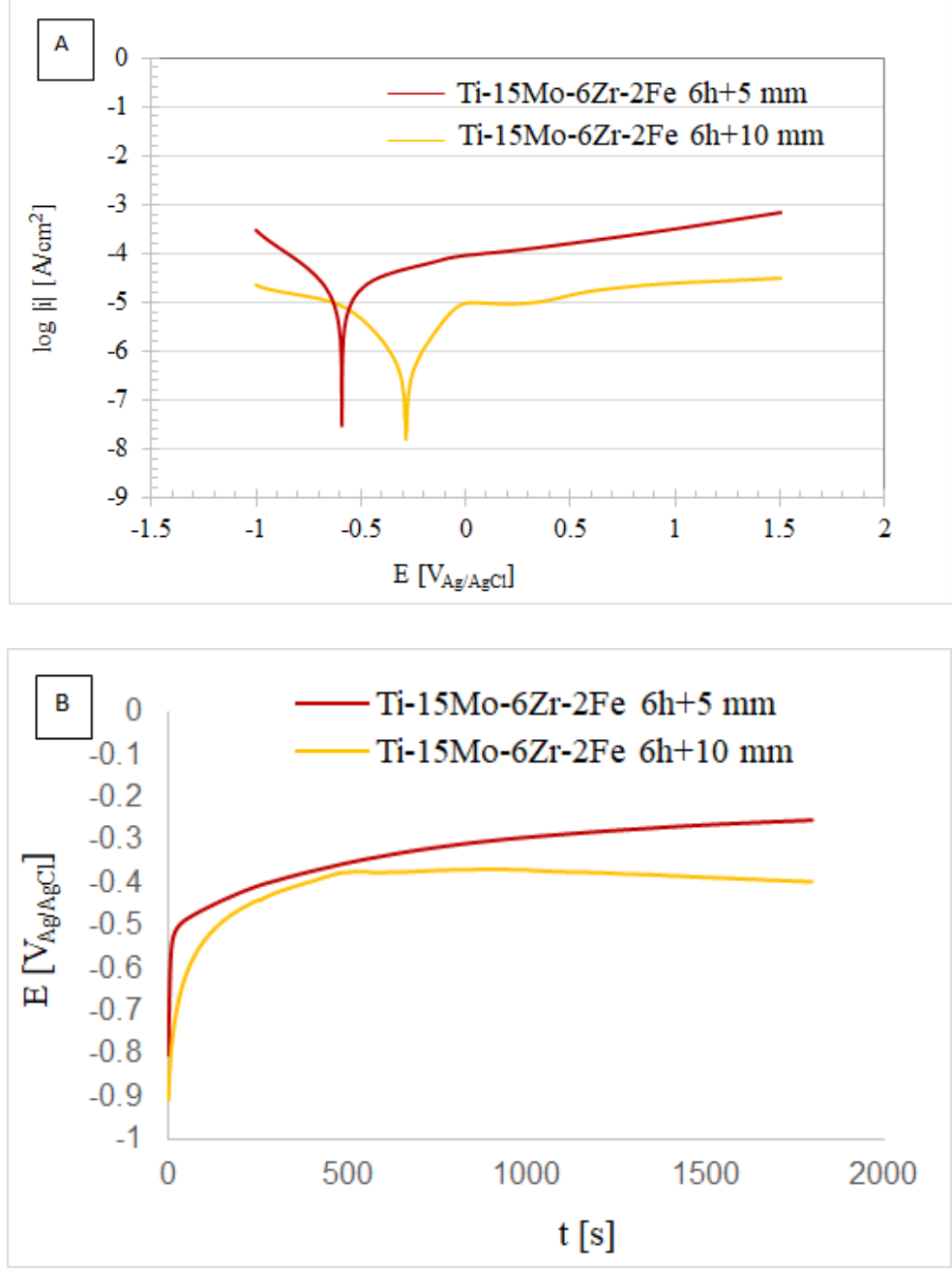

Figure 4.17: Different graphs for corrosion results of MA samples (A) $\log (i)$ vs E for samples with PCA (B) E vs t for samples with PCA

Table 4.33 summarizes the value of ion release rate $C\left[\mu \mathrm{g} / \mathrm{L} \mathrm{cm}{ }^{2} \mathrm{~h}\right]$ of each element in the alloy. For biomaterial application, it should be low. For example, within all the alloys Ti-12Mo-6Zr-2Fe with elemental blend (EB) method have least ion release rate for Ti atom which is better for the implant. Overall EB and SPS have better results in comparison to MA samples. 
Development of new high-performance Titanium alloys with Fe-addition for dental implants

Table 5.33: Ion-release rate of different particle with different parameters for corrosion

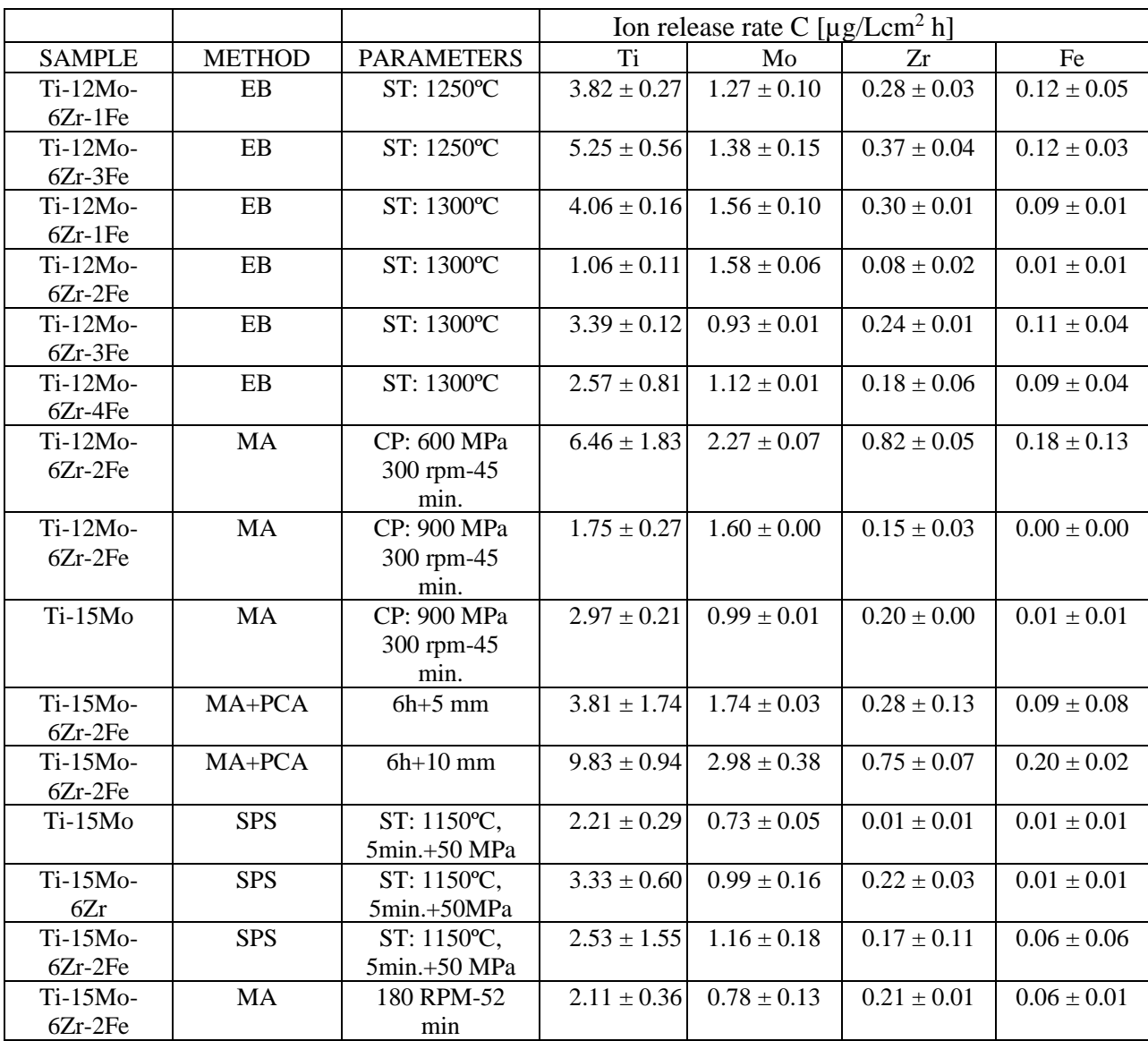

Table 4.34 summarizes the value of (Velocity: $\mathrm{mg} / \mathrm{dm}^{2}$. day) of each element in the alloy. This velocity is calculated with the help of ion release rate. For biomaterial application, it should be low. For example, within all the alloys Ti-12Mo-6Zr-2Fe sintered at $1300^{\circ} \mathrm{C}$ with elemental blend (EB) method have lowest ion velocity. Overall EB and SPS have better results in comparison to MA samples. MA with PCA have more corrosion velocity which is inferior for biomaterials. 
Table 4.34: Corrosion velocity with ion-release rate

\begin{tabular}{|c|c|c|c|c|c|c|c|}
\hline & & & \multicolumn{5}{|c|}{ Velocity: $\mathrm{mg} / \mathrm{dm}^{2} \cdot$ day } \\
\hline SAMPLE & METHOD & PARAMETERS & $\mathrm{Ti}$ & Mo & $\mathrm{Zr}$ & $\mathrm{Fe}$ & sum \\
\hline $\begin{array}{c}\text { Ti-12Mo-6Zr- } \\
1 \mathrm{Fe}\end{array}$ & EB & ST: $1250^{\circ} \mathrm{C}$ & 0.4582 & 0.1519 & 0.0334 & 0.0141 & 0.6576 \\
\hline $\begin{array}{c}\text { Ti-12Mo-6Zr- } \\
3 \mathrm{Fe}\end{array}$ & EB & ST: $1250^{\circ} \mathrm{C}$ & 0.6294 & 0.1658 & 0.0445 & 0.0146 & 0.8543 \\
\hline $\begin{array}{c}\text { Ti-12Mo-6Zr- } \\
1 \mathrm{Fe}\end{array}$ & EB & ST: $1300^{\circ} \mathrm{C}$ & 0.4878 & 0.1866 & 0.0356 & 0.0102 & 0.7203 \\
\hline $\begin{array}{c}\text { Ti-12Mo-6Zr- } \\
2 \mathrm{Fe}\end{array}$ & EB & ST: $1300^{\circ} \mathrm{C}$ & 0.1274 & 0.1894 & 0.0095 & 0.0012 & 0.3276 \\
\hline $\begin{array}{c}\text { Ti-12Mo-6Zr- } \\
3 \mathrm{Fe}\end{array}$ & EB & ST: $1300^{\circ} \mathrm{C}$ & 0.4065 & 0.1115 & 0.0284 & 0.0130 & 0.5594 \\
\hline $\begin{array}{c}\text { Ti-12Mo-6Zr- } \\
4 \mathrm{Fe}\end{array}$ & EB & ST: $1300^{\circ} \mathrm{C}$ & 0.3078 & 0.1345 & 0.0215 & 0.0102 & 0.4741 \\
\hline $\begin{array}{c}\text { Ti-12Mo-6Zr- } \\
2 \mathrm{Fe}\end{array}$ & MA & $\begin{array}{c}\text { CP: } 600 \mathrm{MPa} \\
300 \mathrm{rpm}-45 \\
\text { Min. }\end{array}$ & 0.7756 & 0.2726 & 0.0987 & 0.0220 & 1.1689 \\
\hline $\begin{array}{c}\text { Ti-12Mo-6Zr- } \\
2 \mathrm{Fe}\end{array}$ & MA & $\begin{array}{c}\text { CP: } 900 \mathrm{MPa} \\
300 \mathrm{rpm}-45 \\
\text { Min. }\end{array}$ & 0.2099 & 0.1922 & 0.0183 & 0.0003 & 0.4207 \\
\hline Ti-15Mo & MA & $\begin{array}{c}\text { CP: } 900 \mathrm{MPa} \\
300 \mathrm{rpm}-45 \\
\text { Min. }\end{array}$ & 0.3560 & 0.1188 & 0.0249 & 0.0069 & 0.5067 \\
\hline $\begin{array}{c}\text { Ti-15Mo-6Zr- } \\
2 \mathrm{Fe}\end{array}$ & $\mathrm{MA}+\mathrm{PCA}$ & $6 \mathrm{H}+5 \mathrm{~mm}$ & 0.457 & 0.2084 & 0.0335 & 0.0104 & 0.7091 \\
\hline $\begin{array}{c}\text { Ti-15Mo-6Zr- } \\
2 \mathrm{Fe}\end{array}$ & $\mathrm{MA}+\mathrm{PCA}$ & $6 \mathrm{H}+10 \mathrm{~mm}$ & 1.180 & 0.358 & 0.090 & 0.0239 & 1.6518 \\
\hline Ti-15Mo & SPS & $\begin{array}{c}\mathrm{ST}: 1150^{\circ} \mathrm{C}, \\
5 \mathrm{~min} .+50 \mathrm{MPa}\end{array}$ & 0.266 & 0.088 & 0.001 & 0.0010 & 0.3550 \\
\hline Ti-15Mo-6Zr & SPS & $\begin{array}{c}\mathrm{ST}: 1150^{\circ} \mathrm{C}, \\
5 \mathrm{~min} .+50 \mathrm{MPa}\end{array}$ & 0.400 & 0.1185 & 0.027 & 0.0019 & 0.5466 \\
\hline $\begin{array}{c}\text { S3: Ti-15Mo- } \\
\text { 6Zr-2Fe }\end{array}$ & SPS & $\begin{array}{c}\text { ST: } 1150^{\circ} \mathrm{C}, \\
5 \mathrm{~min} .+50 \mathrm{MPa}\end{array}$ & 0.303 & 0.1390 & 0.021 & 0.0068 & 0.470 \\
\hline $\begin{array}{c}\text { Ti-15Mo-6Zr- } \\
2 \mathrm{Fe}\end{array}$ & MA & $\begin{array}{c}180 \text { RPM-52 } \\
\text { min }\end{array}$ & 0.254 & 0.093 & 0.001 & 0.002 & 0.349 \\
\hline
\end{tabular}

So overall, we have results for EB, MA and SPS powder metallurgy method with different combination of compaction pressure (CP), sintering temperature (ST), milling speed and milling time for MA samples. 
Development of new high-performance Titanium alloys with Fe-addition for dental implants

104 |Page 


\section{Chapter 5: Discussion of the result}

When the $\%$ of Mo is $5 \%$ alloy is equiaxed $\alpha$ and when Mo is more than $10 \%$ the alloy is equiaxed $\alpha$ crystal grain and needle type $\beta$-phases are found but when Mo is more than $15 \%$ only equiaxed $\beta$-phases are found which is confirmed by Chen et al. (Chen et al., 2006), so for this reason we use $(12,15) \%$ for our research. Some authors like $\mathrm{Lu}$ et al. (Lu et al., 2013a) also suggested that when Mo is more than 10\%, the phase is mainly $\beta$. Presence of $\beta$-stabilizer element made zirconium as a non-neutral element and pass to act as on stabilizing $\beta$-phase in that alloy. (Ho, Ju and Chern Lin, 1999; Correa et al., 2018). There is a significant strengthening effect of Fe to Tibased alloys, and Mo is effective in stabilizing $\beta$-phase(Bao et al., 2014).

From table 4.1 relative green density of Ti-15Mo is maximum within all the base alloys which is approx. $78.10 \%$ and least value is for Ti- $12 \mathrm{Mo}-6 \mathrm{Zr}$ which is $77.50 \%$ which is approx. $0.8 \%$ less than Ti-15Mo. Increment in $\%$ of Mo increases the green density which is clear from figure 5.1 and addition of $\mathrm{Zr}$ also reduces the green density which is shown in figure 4.1.

From table 4.1 it is clearly shown that addition of Fe decreases green density up to 2 $\%$ but when $\%$ of Fe increases beyond 3\% green density improves and green density also affects sintered density. Some author like Yang et al. (Yang et al., 2012); who worked with $\mathrm{Ti}-\mathrm{Fe}-\mathrm{Si}$, also discussed about green and sintered density and they confirmed that when $\%$ of $\mathrm{Fe}$ is more than $3 \%$ sinterability increases.

Shrinkage (volume loss) is maximum for Ti-12Mo-6Zr which is clearly shown in figure 5.1 , value is $19.50 \%$ and the minimum is for Ti-15Mo which is $18.30 \%$ which is approx. 5.4\% less than Ti-12Mo-6Zr. Elashalakany et al. (Elshalakany et al., 2017) also claimed that volumetric shrinkage for their alloy (Ti-15Mo-6Zr-xCr) is between $16-20 \%$ which is like our alloy. Delvat et al. (Delvat et al., 2008) also claimed that dimensional loss of Ti-20Mo and Ti-40Mo are between (20-23)\%. Our alloy is better than their alloy because less dimensional loss after sintering is better.

Shrinkage for quaternary alloys decreases with addition of Fe to Ti-12Mo-6Zr shown in figure 5.1. The value for Ti-12Mo-6Zr-4Fe is the least for our alloy; it means 
addition of more $\%$ of Fe decreases the value of shrinkage.

Addition of $\mathrm{Zr}$ increases the value of Shrinkage from $18.5 \%$ to $19.5 \%$ for Ti-12Mo to Ti-12Mo-6Zr and when Fe is added to Ti-12Mo-6Zr; shrinkage values decrease as $\%$ of Fe increases from $1-4 \%$. For Ti-15Mo-6Zr also shrinkage value increases from 18.4 to $19.4 \%$. So, overall range for our alloy is from $18.5-19.5 \%$.

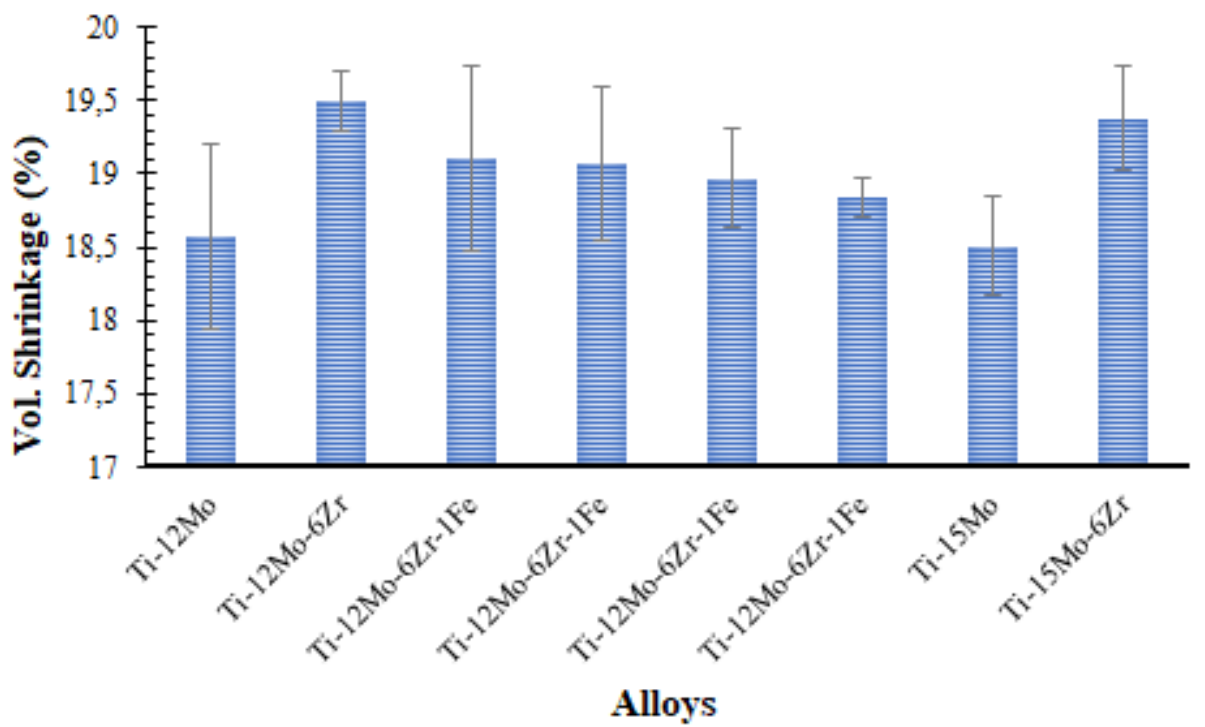

Figure 5.1: Shrinkage of Ti-Mo alloy

Sintered density is the main geometrical property of the alloy which is prepared by powder metallurgy route with press and sintering method. Porosity (100- relative sintered density) is approx. the inverse of the relative sintered density of the sample i.e. if the relative density is higher, porosity is lower and vice versa. We also calculated the value of sintered density $\left(\mathrm{gr} / \mathrm{cm}^{3}\right)$ by the help of relative sintered density and theoretical density, which is shown in table 4.2. For Ti-15Mo sintered density is $4.77\left(\mathrm{gr} / \mathrm{cm}^{3}\right)$ in our case which is prepared by elemental blend and sintering temperature $1250{ }^{\circ} \mathrm{C}$ but some author Martins et al. (Martins Júnior et al., 2011) claimed that for Ti-15Mo is $4.97\left(\mathrm{~g} / \mathrm{m}^{3}\right)$ which used hot-swaging method; which is more than theoretical density of Ti-15Mo which is $4.92\left(\mathrm{~g} / \mathrm{cm}^{3}\right)$. 

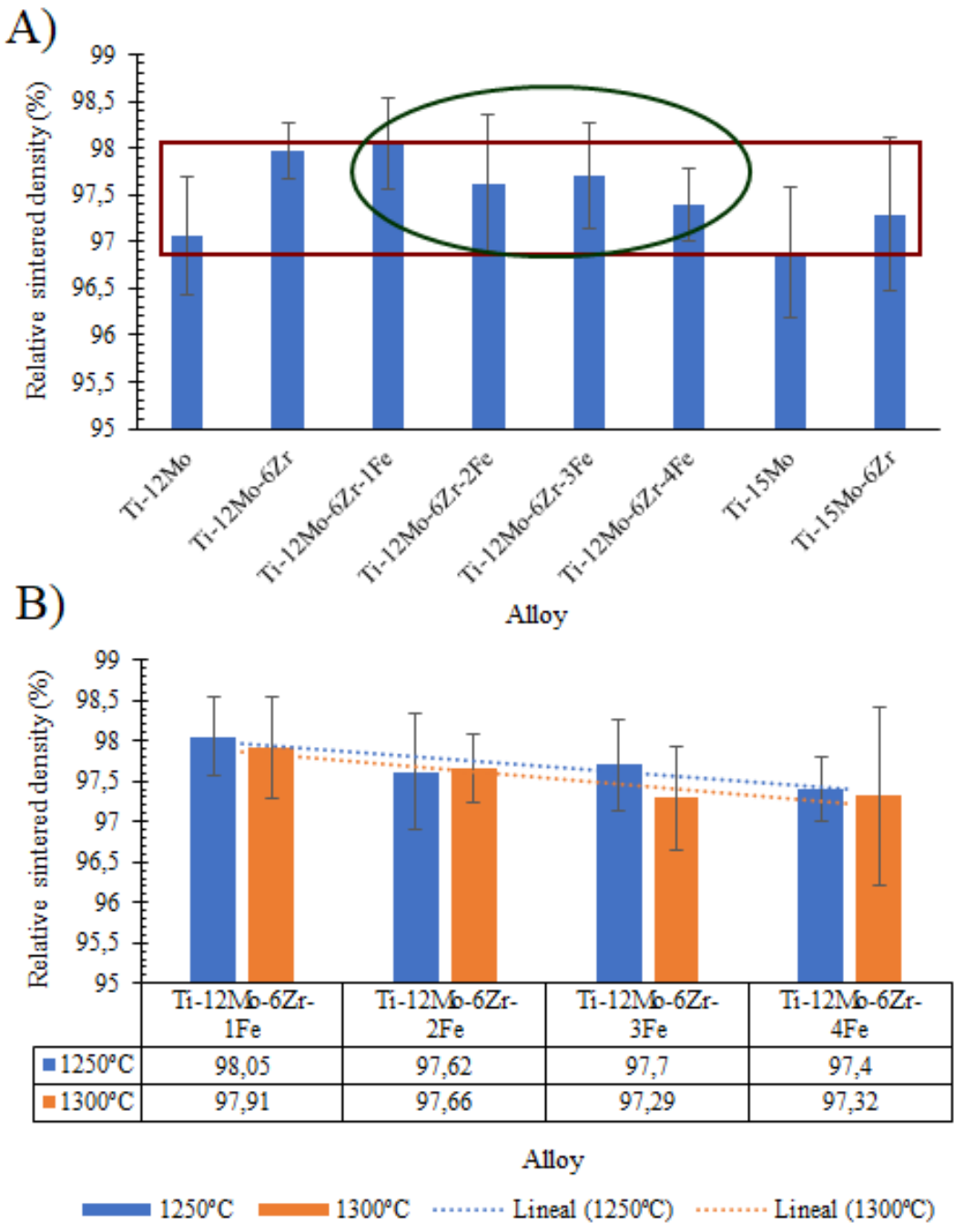

Figure 5.2:(A) Relative sintered density of Ti-Mo alloy (B) Relative sintered density of Ti-Mo-Zr-xFe at different temp.

Addition of $\mathrm{Zr}$ improves the relative sintered density for Ti-12Mo from (97-98) \% approx. $1.01 \%$ more than the relative sintered density of Ti-12Mo, Ti-15Mo- $6 \mathrm{Zr}$ have also higher sintered density of Ti-15Mo from 96.8 to $97.5 \%$. Addition of $\mathrm{Fe}$ 
increases relative sintered density with $1 \%$ of Fe from 97.9 to $98 \%$ and more $\%$ of Fe decreases relative sintered density which is shown in figure 5.2 (A). The range for relative sintered density is (97-98) \% which is denoted by the box. Majumdar et al. (Majumdar et al., 2010) who worked with Mo-0.6Ti-0.2Zr-0.02C by powder metallurgy route at $1800{ }^{\circ} \mathrm{C}$ claimed that sintered density for the alloy is $97 \%$ of the theoretical density.

The relative density has a linear co-relation with $\mathrm{Fe}$ content and sintering temperature which is shown in figure 5.2 (B). Relative density is lower in the case of $1300{ }^{\circ} \mathrm{C}$ for all the alloy but this is little bit higher in the case of Ti-12Mo-6Zr$2 \mathrm{Fe}$ which is shown in figure 5.2 (B). Liu et al. (Liu et al., 2017) also reported the same as the increasing \% of $\mathrm{Fe}$ causes of decrement of relative sintered density.

The range of relative sintered density for Ti-12Mo- $6 \mathrm{Zr}-\mathrm{xFe}$ with both temperature is between (97.33-98.05) which is also tabulated and graphically shown in figure 6.3. Minimum relative density is for $\mathrm{Ti}-12 \mathrm{Mo}-6 \mathrm{Zr}-4 \mathrm{Fe}$ is for both the sintering temperature which is 97.4 and $97.32 \%$ for $1250{ }^{\circ} \mathrm{C}$ and $1300{ }^{\circ} \mathrm{C}$ relatively and maximum is for Ti-12Mo-6Zr- $1 \mathrm{Fe}$ with both temperature which is 98.05 and $97.91 \%$ for $1250^{\circ} \mathrm{C}$ and $1300{ }^{\circ} \mathrm{C}$ relatively. Maximum sintered density is same for Ti-12Mo$6 \mathrm{Zr}-4 \mathrm{Fe}$ with both temperature which is $4.89\left(\mathrm{gr} / \mathrm{cm}^{3}\right)$.

Bending strength is maximum for Ti-15Mo which is $2161 \mathrm{MPa}$. Addition of $\mathrm{Zr}$ and Fe decreases the value of bending strength which is clearly shown by the value of $\mathrm{Ti}-12 \mathrm{Mo}-6 \mathrm{Zr}$ in comparison to Ti-12Mo and $\mathrm{Ti}-15 \mathrm{Mo}-6 \mathrm{Zr}$ in comparison to Ti$15 \mathrm{Mo}$ which shows the effect of $\mathrm{Zr}$ on Ti-Mo alloy which causes decrement of the value of bending strength. More \% of Mo (from 12-15) causes increment of bending strength shown by the figure $5.3(\mathrm{~A})$.

Addition of $\mathrm{Fe}$ to Ti-12Mo-6Zr also decreases the value of bending strength. More $\%$ of Fe decreases the value of bending strength shown by the value of Ti-12Mo$6 \mathrm{Zr}-1 \mathrm{Fe}$ to $\mathrm{Ti}-12 \mathrm{Mo}-6 \mathrm{Zr}-4 \mathrm{Fe}$ which shows decreasing trend of the bending strength with the more $\%$ of Fe. The range for the bending strength for our alloy is very high which is from (650-2150) MPa which is denoted by the box in figure 6.4. Ho et al. (Ho et al., 2009) claimed that bending strength of Ti-10Zr-1Mo is $1177 \mathrm{MPa}$ which is $20 \%$ more than Ti-10Zr and $40 \%$ more than bending strength of C.P Ti (Davis, 2003); which is $844 \mathrm{MPa}$. Addition of $\mathrm{Zr}$ reduced the value of bending strength which is also confirmed by Ho et al. (Ho et al., 2009). Addition of $\mathrm{Zr}$ reduced the value of bending strength approx. $5 \%$ in case of Ti-12Mo but $20 \%$ decrement in case 
of Ti-15Mo which is clearly shown in figure 6.4. Addition of Fe also decreases the value of bending strength to (24-40) \% which is also shown in figure 5.3 (A). So, addition of $\mathrm{Zr}$ and $\mathrm{Fe}$ reduced the value of bending strength. Chen et al. (Chen et al., 2006) claimed the compression strength of Ti-xMo ( $\mathrm{x}=5-20)(1546-1876) \mathrm{MPa}$ which is similar to our alloy Ti-12Mo and Ti-15Mo bending strength value.
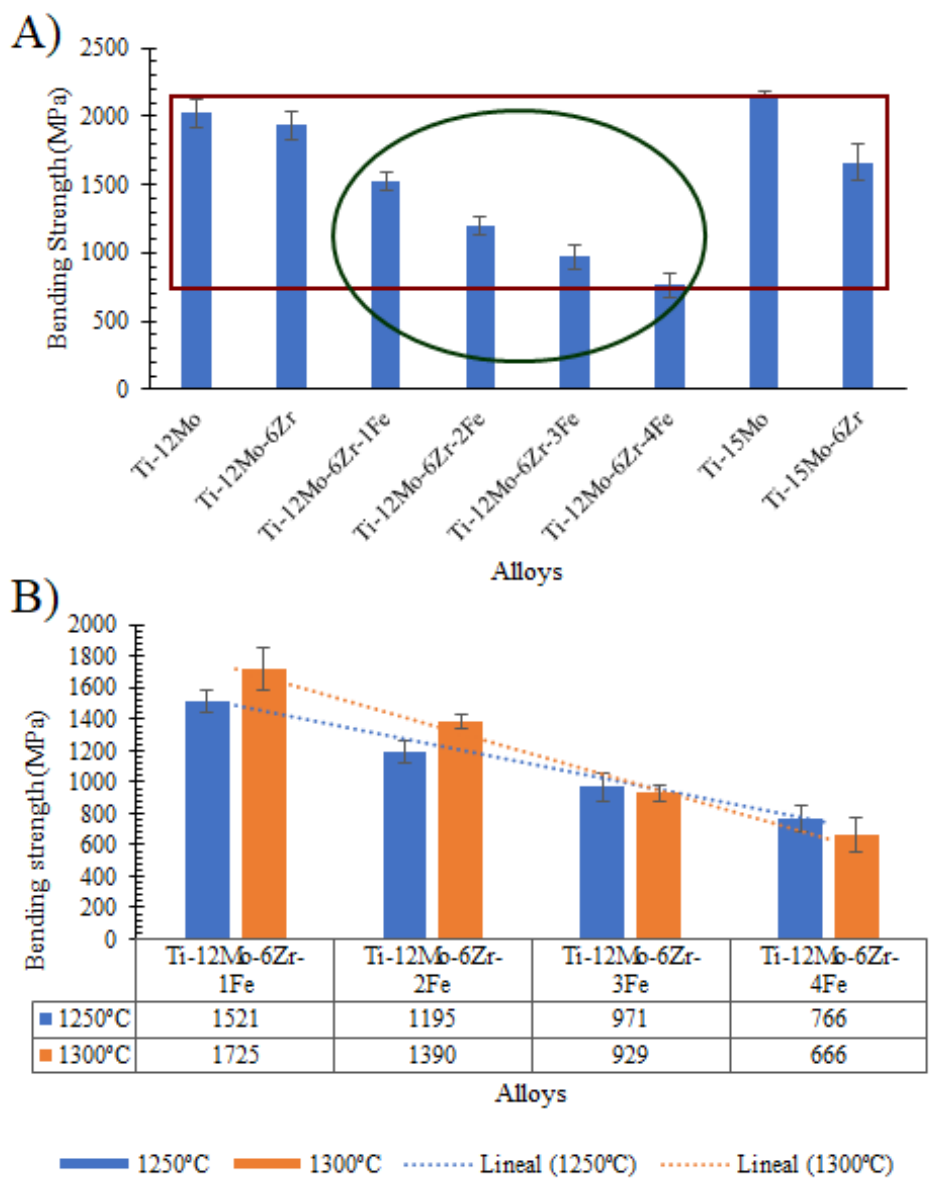

Figure 5.3: (A) Bending strength of Ti-Mo alloy (B) Bending strength of Ti-Mo-Zr-xFe at different temperatures 
Bending strength shows linear trend with the addition of $\mathrm{Fe}$ and with the both temperature, which is clearly shown by figure 5.3 (B). Bending strength is more with higher temperature for Ti-12Mo-6Zr-1Fe and Ti-12Mo-6Zr-2Fe. The value is less with higher temperature for Ti-12Mo-6Zr-3Fe and Ti-12Mo-6Zr-4Fe which is clearly shown in figure 6.5 . Value is least for Ti-12Mo-6Zr-4Fe for both temperature which is 766 and $666 \mathrm{MPa}$ for $1250^{\circ} \mathrm{C}$ and $1300^{\circ} \mathrm{C}$ respectively and maximum is for $\mathrm{Ti}-12 \mathrm{Mo}-6 \mathrm{Zr}-1 \mathrm{Fe}$ for both sintering temperature which is 1521 and $1725 \mathrm{MPa}$ for $1250^{\circ} \mathrm{C}$ and $1300^{\circ} \mathrm{C}$ respectively. (Ho, Wu, Hsu, et al., 2012) also claimed that bending strength for Ti-10Zr and Ti-10Zr-xMo have higher bending strength (14722098) $\mathrm{MPa}$ which is higher than bending strength of Ti C.P which is $844 \mathrm{MPa}$.

Elastic modulus is the main mechanical properties for biomaterial; and should be lower/ like bone which should be in between (17-28) GPa; which is suggested by different scientists Niinomi et al. (Niinomi, 1998; Nag, Banerjee and Fraser, 2007; Geetha et al., 2009; Ho, Wu, Hsu, et al., 2012). Minimum value is for Ti-12Mo-6Zr$3 \mathrm{Fe}$ with both sintering temperature $\left(1250^{\circ} \mathrm{C}\right.$ and $\left.1300^{\circ} \mathrm{C}\right)$ which is approx. $95 \mathrm{GPa}$ and maximum is for Ti-12Mo which is approx.105 GPa. Elastic modulus for Ti$15 \mathrm{Mo}$ is lower than Ti-12Mo; maybe the decrement of elastic modulus in Ti-15Mo is due to $\beta$-character of more $\%$ of Mo which is also confirmed by different scientist (Chen et al., 2006; Lu et al., 2013b). Addition of Fe causes decrement in elastic modulus and the nature is decreasing order for Ti-12Mo- $6 \mathrm{Zr}-\mathrm{xFe}(\mathrm{x}=1-3)$ but for Ti$12 \mathrm{Mo}-6 \mathrm{Zr}-4 \mathrm{Fe}$ elastic modulus is more than $\mathrm{Ti}-12 \mathrm{Mo}-6 \mathrm{Zr}-3 \mathrm{Fe}$ and trend change. The range of elastic modulus is between (95-105) GPa for our alloys which is denoted by rectangle box in figure 5.4 (A). In previous studies elastic modulus of $\beta$ alloy is in between (55-124) GPa (Nag et al., 2005; Geetha et al., 2009).These values are less than $\alpha$ and $(\alpha+\beta)$ alloys (Martins Júnior et al., 2011).

Elastic modulus (EM) shows linear trend with sintering temperature and $\%$ of Fe but with Ti-12Mo-6Zr-3Fe there is a change in trend. For higher temperature elastic modulus is more in case of Ti-12Mo-6Zr-1Fe, Ti-12Mo-6Zr-2Fe and Ti-12Mo-6Zr$4 \mathrm{Fe}$. EM is less with higher temperature in case of Ti-12Mo-6Zr-3Fe; shown in figure 5.4 (B) and tabulated below the graph. The least value is for Ti-12Mo-6Zr$3 \mathrm{Fe}$ which is $95 \mathrm{GPa}$ and it's more suitable as bio-material application due to less requirement of elastic modulus which is confirmed by Niinomi, Geetha et al. and Martins et al. (Niinomi, 1998; Geetha et al., 2009; Martins Júnior et al., 2011). Elastic modulus value for Ti-Mo alloy is much less than stainless steel(210 GPa),Co- 
Cr alloys (240 GPa) pure Ti, Ti-6Al-4V(120 GPa)(Niinomi, 1998) and so on (Geetha et al., 2009; Correa et al., 2018).

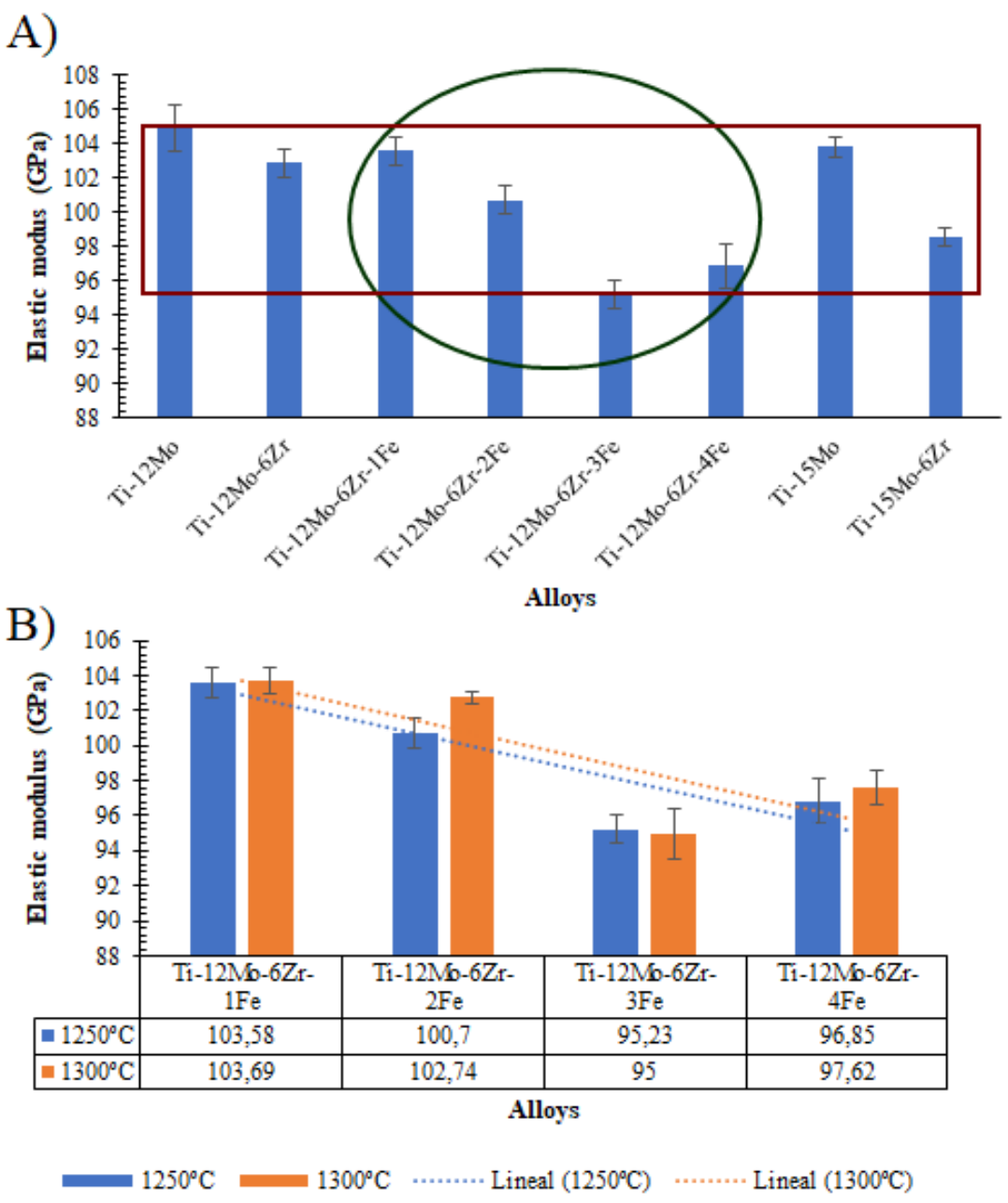

Figure 5.4: (A) Elastic modulus of Ti-Mo alloy (B) Elastic modulus of Ti-Mo-Zr-xFe at different temperatures

Ti-Mo alloys have normally lower elastic modulus who claimed elastic modulus increases upto $6 \%$ (for Ti-6Mo is $112 \mathrm{GPa}$ ) and then decreases the value till $8 \%$ of Mo (82.98 GPa) for Ti-Mo alloy (Zhang et al., 2015). Elastic modulus for Ti-10Zr- 
5Mo and Ti-10Zr-12.5Mo is 87 and $96 \mathrm{GPa}$ respectively (Ho, Wu, Kuang, et al., 2012) which is similar to elastic modulus for Ti-12Mo-6Zr-3Fe with both sintering temperature which is $95 \mathrm{GPa}$ and also this is less than Ti C.P (99 GPa). Elastic modulus with higher content of Mo shows lower value which is also confirmed by Correa et al. (Correa et al., 2018).Ti-35Nb-4Sn-6Mo-9Zr have elastic modulus of 68 GPa which is claimed by Dai et al.(Dai et al., 2013).Ti-12Mo-5Ta have elastic modulus less than our alloy which is claimed by Gordin et al.(Gordin et al., 2005).
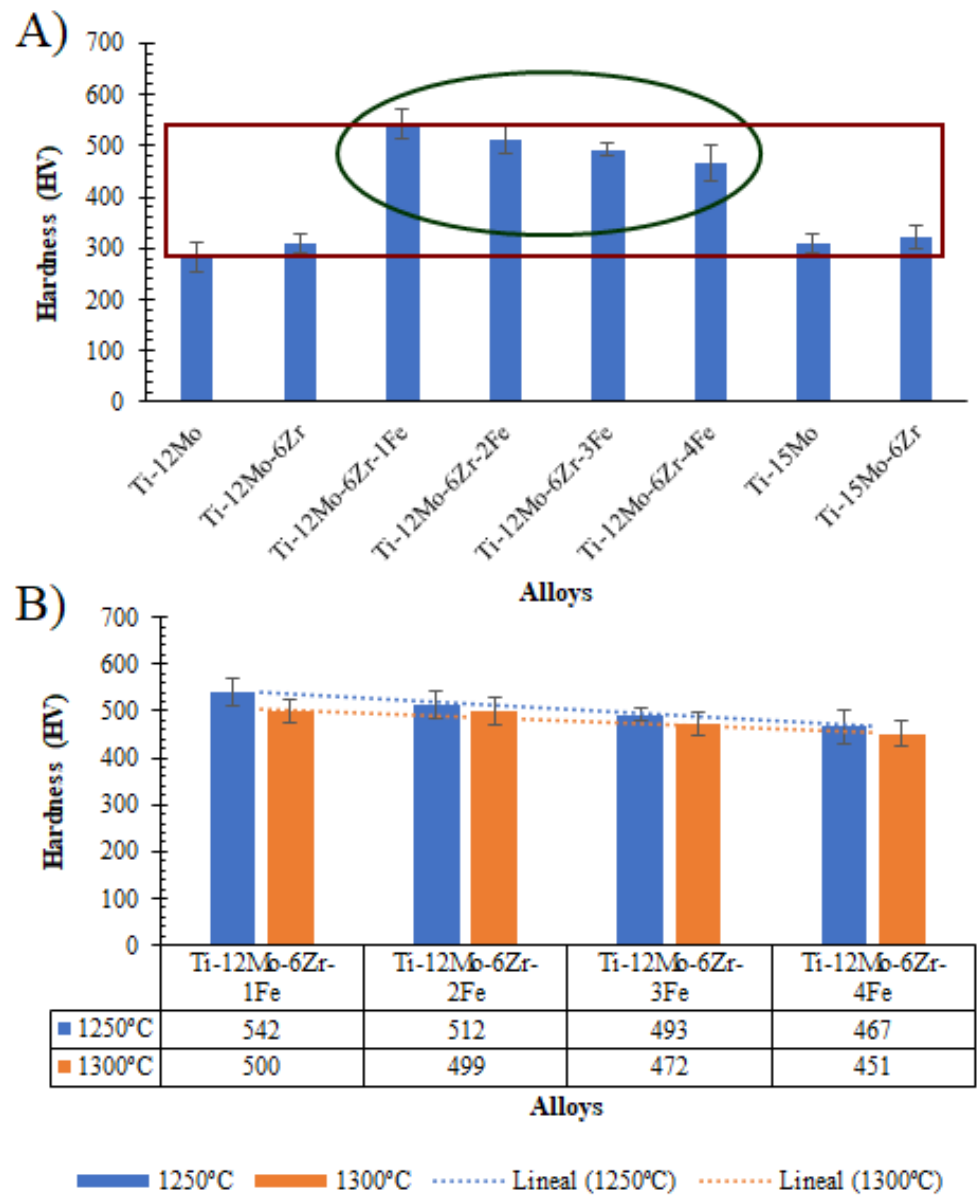

Figure 5.5: (A) Hardness of Ti-Mo alloy (B) Hardness of Ti-Mo-Zr-xFe at different temperatures 
Hardness is also an important property for biomaterial application alloys. Hardness is least for Ti-12Mo which is $283 \mathrm{HV}$ and maximum is for Ti-12Mo-6Zr-1Fe (sintered at $1250{ }^{\circ} \mathrm{C}$ ) which is $542 \mathrm{HV}$. So, the range of hardness for our alloy is between (283-542) HV which is denoted by rectangle box in figure 5.5 (A). Addition of $\mathrm{Zr}$ increases the value of hardness in both binary alloy Ti-12Mo and Ti-15Mo i.e hardness for Ti-12Mo-6Zr (309 HV) is more than Ti-12Mo (283 HV); which is less than $10 \%$ and similar is for Ti-15Mo-6Zr. Addition of Fe also increases hardness value with Ti-12Mo-6Zr and for Ti-12Mo-6Zr-1Fe (542 HV) is approx. 64\% more than the value of Ti-12Mo-6Zr. More \% of Fe decreases the value of hardness shown in figure $5.4(\mathrm{~A})$.

Ti-12Mo-6Zr-xFe has a decreasing trend of hardness from $(\mathrm{x}=1-4)$. Kuroda et al. (Kuroda, Buzalaf and Grandini, 2016) claimed that hardness of Ti-Mo alloys are more than $\mathrm{CP} \mathrm{Ti}$, it's due to solid solution hardening effect due to addition of Mo and $\mathrm{Zr}$ (Ho, Ju and Chern Lin, 1999). More \% of Mo increases the value of hardness, it's due to formation of $\alpha^{\prime \prime}$ phase which has higher value of hardness than $\alpha^{\prime}$ phase which is confirmed by Kuroda et al.(Kuroda, Buzalaf and Grandini, 2016); maybe for this reason Ti-15Mo have more hardness value than Ti-12Mo.Ti-12Mo-6Zr-4Fe have the less value of hardness in comparison to other quaternary alloys; maybe this is due to more $\%$ of $\beta$-phase in case of Ti-12Mo- $6 \mathrm{Zr}-4 \mathrm{Fe}$ which is also confirmed by Kuroda et al. (Kuroda, Buzalaf and Grandini, 2016).Ti-15Mo have micro-hardness approx. $325 \mathrm{HV}$ after swaging which is claimed by Martins et al.(Martins Júnior $e t$ al., 2011).

Hardness shows linear trend with temperature and \% of Fe which is clearly shown in figure 5.5 (B). Higher temperature shows less hardness in comparison to lower sintering temperature. More $\%$ of Fe has less value of hardness in both cases. So Ti$12 \mathrm{Mo}-6 \mathrm{Zr}-4 \mathrm{Fe}$ with $1300^{\circ} \mathrm{C}$ has least hardness among all the quaternary alloys and value is $451 \mathrm{HV}$. Effect of Fe addition have more effect than sintering temperature. Zardiackas et al. (Zardiackas, Mitchell and Disegi, 2017) claimed that hardness for Ti-15Mo manufactured with multiple vacuum melting technique have hardness value of $291.4 \mathrm{HV}$ which is similar to Ti-15Mo (309 HV) with elemental blend techniques but elastic modulus claimed by Zardiackas et al. (Zardiackas, Mitchell and Disegi, 2017) for Ti-15Mo is $77.7 \mathrm{GPa}$ which is much lower than our alloy Ti$15 \mathrm{Mo}(103 \mathrm{GPa})$; it may be due to change in manufacturing process. Micro-hardness for Ti-15Zr-7.5Mo and Ti-15Zr-15Mo which is prepared by argon arc melting are 479 and 398 HV respectively which is claimed by Correa et al. (Correa et al., 2016) 
and the value for Ti-15Mo-7.5 Mo is similar value to Ti-12Mo- $6 \mathrm{Zr}-2 \mathrm{Fe}$ with $1250^{\circ} \mathrm{C}$ and $1300^{\circ} \mathrm{C}$ which is 467 and $451 \mathrm{HV}$ respectively. Elastic modulus for Ti-15Zr$7.5 \mathrm{Mo}$ and $\mathrm{Ti}-15 \mathrm{Zr}-15 \mathrm{Mo}$ which is prepared by argon arc melting are 114 and 74 GPa which is claimed by Correa et al. (Correa et al., 2016) and value of Ti-15Mo$7.5 \mathrm{Mo}$ is more in comparison with all the alloys.
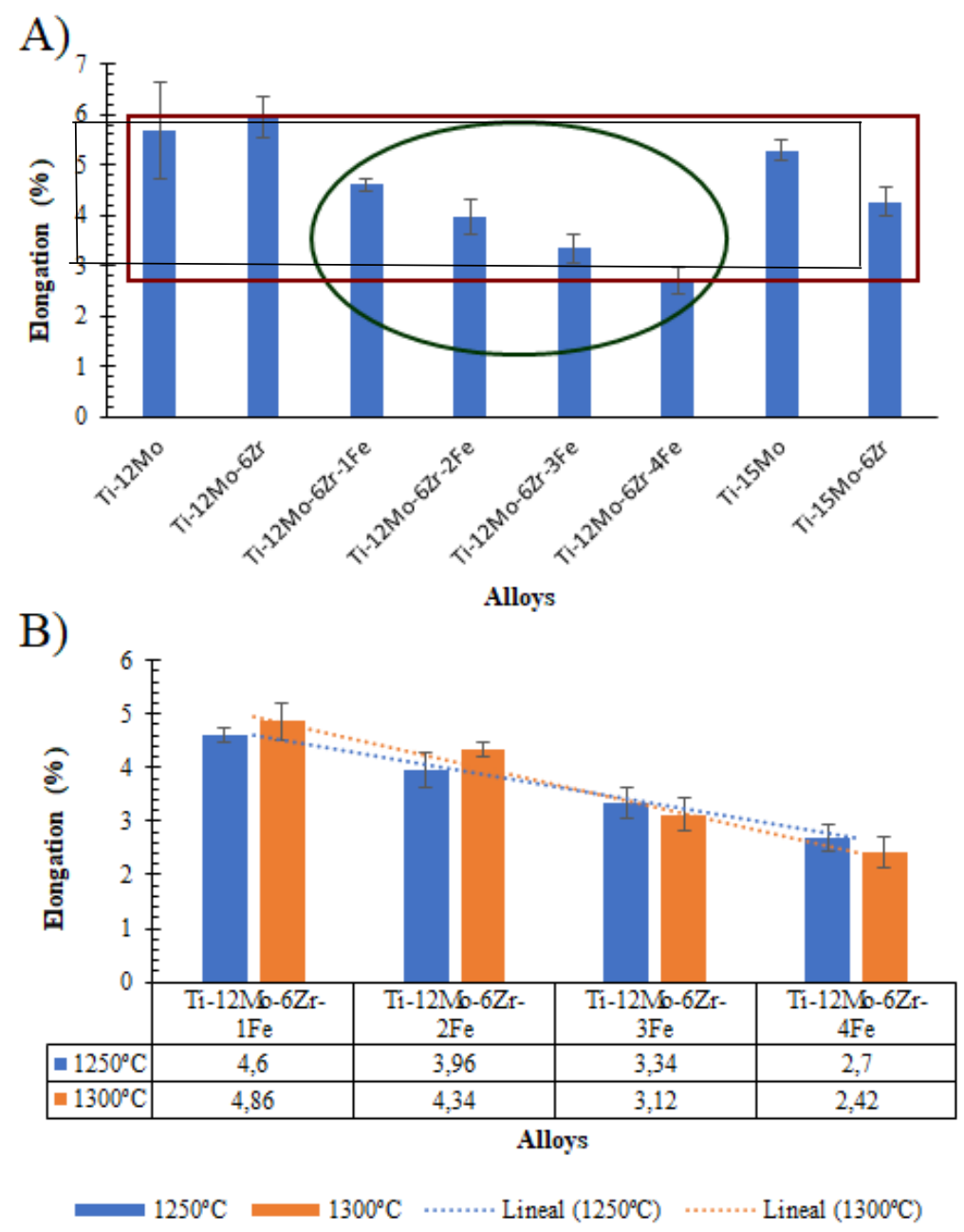

Figure 5.6: (A) Elongation to fracture of Ti-Mo alloy (B) Elongation to fracture of Ti-Mo-Zr-xFe at different temperatures 
Elongation is also a main property for all the biomaterials, and it should be in the range of $(10-20 \%)$ but with powder metallurgy techniques, there is problem in elongation. Elongation is maximum in case of Ti-12Mo-6Zr which is $5.95 \%$. Addition of $\mathrm{Zr}$ has different behaviour with Ti-12Mo and Ti-15Mo; for Ti-12Mo the value of elongation increases from (5.67 to 5.95) but for Ti-15Mo the value of elongation decreases with $\mathrm{Zr}$ so the value of elongation for $\mathrm{Ti}-15 \mathrm{Mo}-6 \mathrm{Zr}(4.27 \%)$ is less than elongation of Ti-15Mo (5.28\%). Addition of Fe shows continue decrement with higher $\%$ of $\mathrm{Fe}$ from (4.60-2.70\%). For our alloys the least value is for Ti$12 \mathrm{Mo}-6 \mathrm{Zr}-4 \mathrm{Fe}$ with $1300{ }^{\circ} \mathrm{C}$ which is $2.42 \%$. The range of elongation for our alloy is between (2.70-5.95) \% which is denoted by rectangular box in figure 5.6 (A). TMZF(Ti-12Mo-6Zr-2Fe) annealed have elongation is (18-22)\% (Wang, 1996) which is much higher than our elongation values and this is due to different in process.

Addition of $\mathrm{Fe}$ shows linear decreasing trend for both the temperature $\left(1250^{\circ} \mathrm{C}\right.$ and $1300^{\circ} \mathrm{C}$ ) shown in figure $5.6(\mathrm{~B}) . \mathrm{Ti}-28 \mathrm{Nb}-13 \mathrm{Zr}-0.5 \mathrm{Fe}$ with quenching have the lowest young's modulus $(58 \mathrm{MPa}) \&$ yield strength $(780 \mathrm{GPa}) \&$ higher fracture plasticity (13\% ) elongation (Cui and Guo, 2009). Ti-15Mo have with multiple vacuum melting techniques have elongation to fracture 20.9\% (Zardiackas, Mitchell and Disegi, 2017).

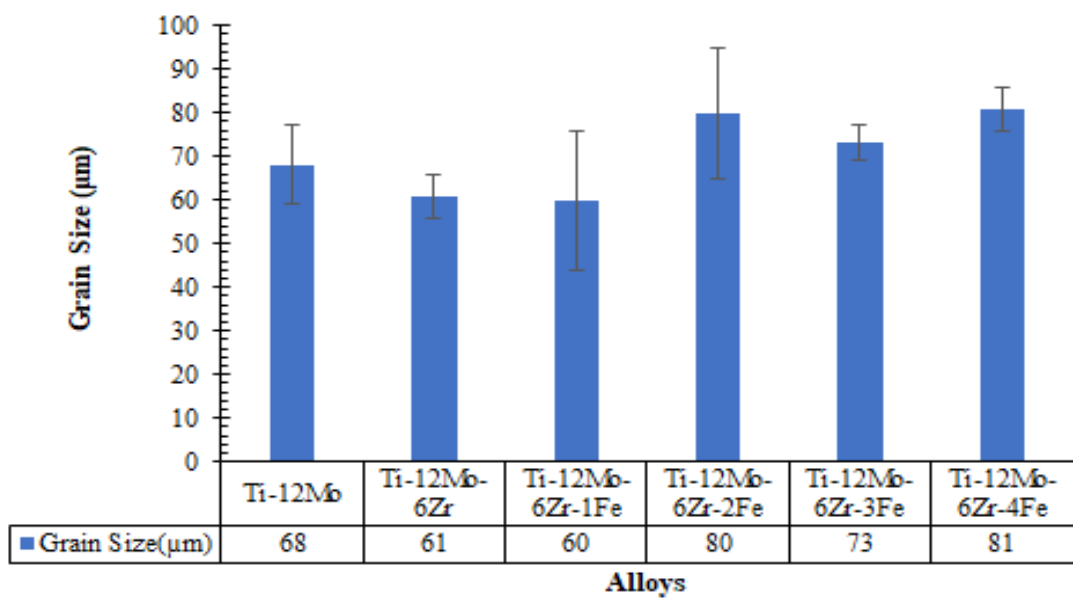

Figure 5.7: Grains size of Ti-Mo alloy 
Elongation to fracture for Ti-6Al-4V as cast have $14.6 \%$ which is also more than TiMo alloys by powder metallurgy due to brittle/less ductile character with powder metallurgy. Elongation for Ti-6Al-4V with elemental blend is in the range of (819)\% with hydride-dihydride (HDH) and hunter sponge fines (SP) (Fujita et al., 1996). Elongation of Ti-6Al-4V with conventional elemental blend (EB) is 6\%(Liu et al., 2006) which is comparable to our alloys which is also prepared by Elemental blend.

Grain size for Ti-Mo alloys is in range (60-81) $\mu \mathrm{m}$ shown in figure 5.7. Normally quaternary alloys have more grain size in comparison to binary alloy and ternary alloy but for Ti-12Mo-6Zr-1Fe grain size is in range of $60 \mu \mathrm{m}$. Min et al.(Min et al., 2010) claimed that for Ti-15Mo and Ti-15Mo-1Fe grain size is in range of $130 \mu \mathrm{m}$.

Ti-6Al-7Nb with powder metallurgy has grain size is in range of $(134 \pm 17) \mu \mathrm{m}$ at sintering temperature $1250^{\circ} \mathrm{C}$ which is claimed by Bolzoni et al. (Bolzoni et al., 2013) and this value is much more than our alloy.

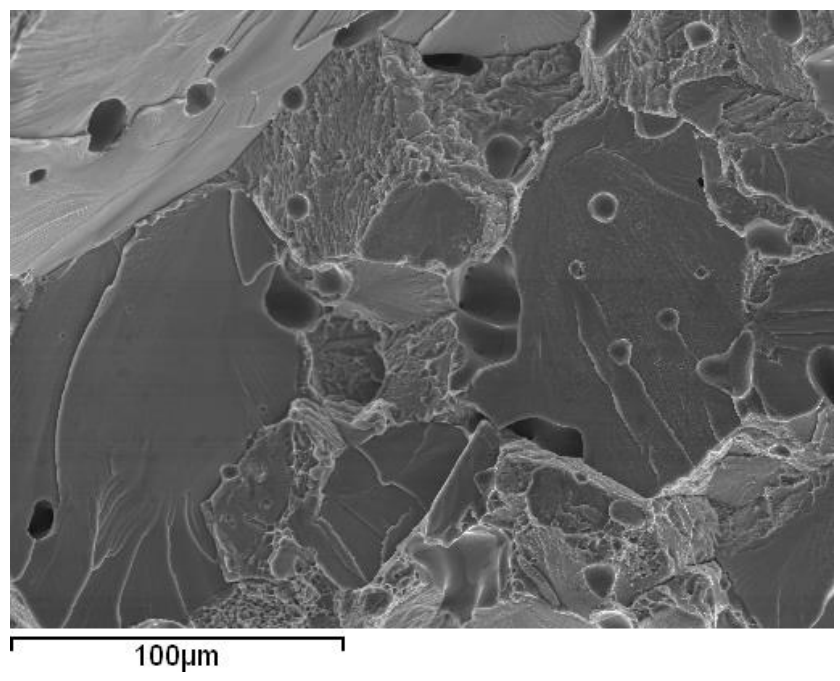

Figure 5.8: Fractography of Ti-12Mo-6Zr-4Fe

Fractography image of Ti-12Mo-6Zr-4Fe reveals that the fracture with higher $\%$ of Fe has mainly brittle fracture which is clearly shown in figure 5.8. Formation of dimples in case of binary and ternary alloys so the fracture is mixed type i.e; (brittle+ ductile) fracture which is shown in result part (Figure 4.1). Addition of Fe causes 
more cleavage planes and smooth fractured surface which causes more brittleness. As per increment of $\%$ of Fe have more brittle surface; shown in figure 4.2. Zr-12MoxTi prepared by vacuum arc melting have mixed type of fracture i.e; brittle and plastic mechanism which is confirmed by Nie et al. (Nie et al., 2014). Ti-15Mo-6Zr prepared by powder metallurgy technique have cleavage facets which indicates reduced ductility and $\mathrm{Ti}-15 \mathrm{Mo}-6 \mathrm{Zr}-\mathrm{xCr}$ have few dimples and cleavage structure which causes mixed type of fracture brittle and plastic mechanism which confirmed by Elshalakany et al. (Elshalakany et al., 2017). Fracture characteristics of these alloys are like our alloys which is prepared by powder metallurgy technique. Ti$8 \mathrm{Mo}-12 \mathrm{Fe}$ prepared with powder metallurgy using vacuum sintering between 1423k-1523k have brittle structure confirmed by Tsai et al. (Tsai et al., 2012).

Grain size is irregular i.e some are bigger, and some are smaller. $\beta$-phase are found mostly in the alloy, but $\alpha$-phase are found on the grain boundary of the alloy. Mixing of the element is homogeneous which is confirmed by the EDS analysis which is also confirmed by figure 4.5 . Increase in $\%$ of Fe causes more porosity which also seen in figure 4.4. Porosity is normally circular in shape and some are also irregular shape. Ti-12Mo and Ti-15Mo have less porosity found on the surface in comparison to Ti-12Mo-6Zr and Ti-15Mo-6Zr which can see by figure 4.3.

Number of grains decreases with higher $\%$ of Fe for Ti-12Mo-6Zr-xFe $(\mathrm{x}=1-4)$ alloy and grain size increases which is seen in figure 4.4. $\beta$-phase increases with higher $\%$ of $\mathrm{Fe}$ and addition of $\mathrm{Zr}$ and $\mathrm{Fe}$ to Ti-Mo and Ti-Mo-6Zr also improves the $\beta$-phase which is confirmed by XRD analysis (as shown in figure 5.6) and EBSD analysis (tabulated in 4.29). For quaternary alloys like Ti-12Mo-6Zr-3Fe; $\beta$-phases reaches almost $100 \%$. Average $\beta$-phases decreased with higher $\%$ of Fe with elemental blend techniques and from EDX analysis; it is also confirmed the good distribution of alloying element from my previous paper (Mohan et al., 2017). Due to solubility of alloying element in $\mathrm{Zr}$, the alloy $\mathrm{Zr}$-12Mo-xTi have equiaxed $\beta$ crystal grain can be observed (Nie et al., 2014). Microstructure of CP Ti mainly have single-phase $\alpha$ grains. Ti-35Nb-5.7Ta-7.2Zr (TNTZ) with solution treated at $800^{\circ} \mathrm{C}$ followed by water quenched (WQ) reveals the presence of equiaxed $\beta$-grains (Majumdar, Singh and Chakraborty, 2008). Ti-15Mo is $\beta$-alloy with single-phase micro-structure, Ti$6 \mathrm{Al}-7 \mathrm{Nb}$ is $(\alpha+\beta)$ alloy which confirmed by Zardiackas et al. (Zardiackas, Mitchell and Disegi, 1997).

$\alpha$-phases found mainly on the boundaries as well as the interior of the grain for Ti$15 \mathrm{Mo}$ alloy after ageing. The micro-structure of $\mathrm{Ti}-13 \mathrm{Mo}-7 \mathrm{Zr}-3 \mathrm{Fe}$ consists primarily 
mainly of $\beta$-grains with grain boundary $\alpha$ and some intra-granular $\alpha$-precipitation at a relatively coarser scale (Nag et al., 2005). The above microstructure is similar to our alloy with $\beta$-grain mainly and $\alpha$-phase at grain-boundary for Ti-Mo-Zr-Fe in our case.

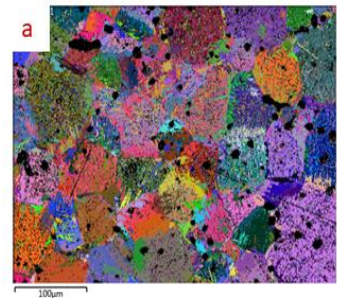

Euler color

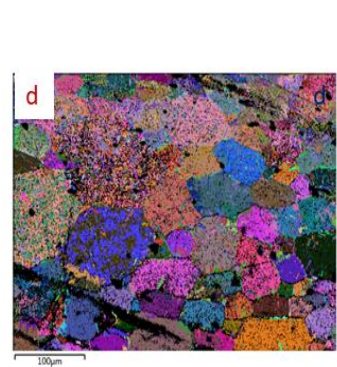

Euler color

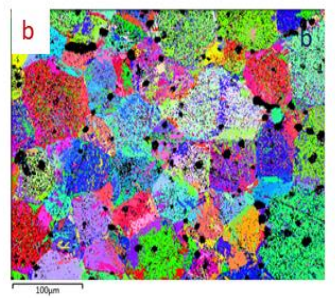

IPF X

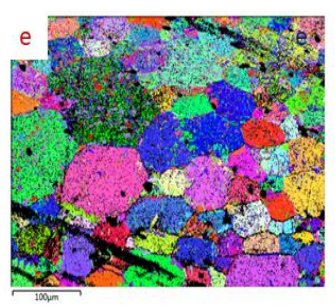

IPF X

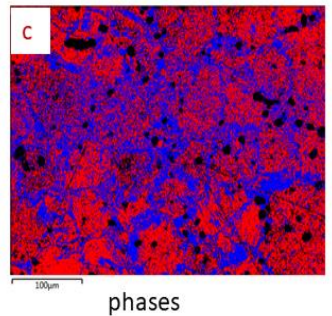

phases

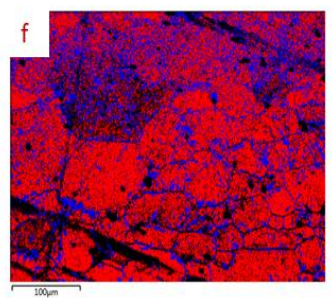

phases

Ti12Mo6Zr

Figure 5.9: Euler color image of Ti12Mo (a) IPF X image of Ti12Mo (c) Phases image of Ti12Mo (d) Euler color image of Ti12Mo6Zr (e) IPF X image of Ti12Mo6Zr (f) Phases image of Ti12Mo6Zr

EBSD images of Ti12Mo and Ti12Mo6Zr are shown in figure 5.9, which includes Euler colours, IPF $X$ and phases of the after- sinter. The grains are equiaxed and grain size is different. Some big grains are found near the small grains. Blue lines in phases image indicate the $\%$ of $\alpha$ inside the alloy. So, it can be clearly seen that in case of Ti12Mo; more \% of $\alpha$ available in comparison to Ti12Mo6Zr. That means here $\mathrm{Zr}$ acts as $\beta$-stabilizer which also confirmed by XRD image of Ti12Mo6Zr in figure 6. With the help of AzTec software we calculated the grain size of Ti12Mo \& Ti12Mo6Zr. Overall grain size for Ti12Mo is $6.89 \mu \mathrm{m}$, $\alpha$ grain size is $4.97 \mu \mathrm{m}$ and $\beta$ grain size is $8.59 \mu \mathrm{m}$. In case of Ti12Mo6Zr Overall grain size is $6.85 \mu \mathrm{m}, \alpha$ grain size is $6.21 \mu \mathrm{m}$ and $\beta$ grain size is $7.47 \mu \mathrm{m}$. So, for both alloy grain size for $\beta$-grain is larger than $\alpha$-grain. In case of Ti12Mo6Zr, $\beta$ grain size is dominating than 
Ti12Mo. We also calculated $\%$ of $\alpha$ and $\beta$ for Ti12Mo and Ti12Mo6Zr with phases diagram as shown in figure 5.16 (c) for Ti12Mo and 6.16 (f) for Ti12Mo6Zr; so, for Ti12Mo, $\alpha$ and $\beta$ are 41.3 and $58.7 \%$ and for Ti12Mo6Zr, $\alpha$ and $\beta$ are 27.7 and 72.3 $\%$ respectively. So, also from EBSD analysis addition of $\mathrm{Zr}$ enhanced the $\beta \%$ as discussed above.

\section{IPF X Color 1}

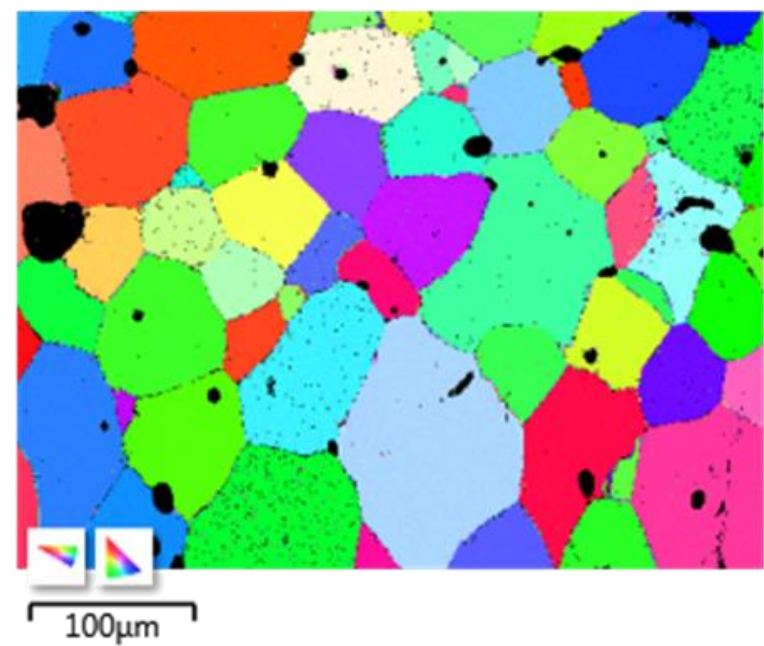

Figure 5.10: IPFX colour image by EBSD analysis of Ti-12Mo-6Zr-3Fe at $1250^{\circ} \mathrm{C}$

For Ti-Mo quaternary alloys, mainly phases are $\beta$-phases. From the analysis for Ti$12 \mathrm{Mo}-6 \mathrm{Zr}-3 \mathrm{Fe}$ with both the sintering temperature $1250^{\circ} \mathrm{C}$ and $1300^{\circ} \mathrm{C} ; \beta$-phase available are $99.04 \%$ and $99.74 \%$ means approx. $100 \%$. Grain size for Ti-12Mo-6Zr$3 \mathrm{Fe}$ at $1250^{\circ} \mathrm{C}$ is $8.46 \mu \mathrm{m}$ and $1300^{\circ} \mathrm{C}$ is $9.98 \mu \mathrm{m}$. From the analysis, the standard of the element is of factory standard. From the EBSD results of Ti-12Mo-6Zr-2Cr prepared by elemental blend have $\alpha$-phase on the grain boundary indicated by the color key of the standard triangle (Elshalakany et al., 2017). The (110) $\beta$ and (111) $\beta$ are the compact planes in $\mathrm{Ti}_{84} \mathrm{Mo}_{16}$ nitride structure (Gordin et al., 2010).

From the XRD analysis, it is seen that $\alpha$-phases peak are mainly seen for binary alloys like Ti-12Mo and Ti-15Mo but even for ternary alloys like Ti-12Mo-6Zr and Ti-15Mo-6Zr; $\alpha$-phase peaks disappear, for quaternary alloys also $\alpha$-phase 
disappears which shown in figure 4.6. From the XRD analysis, addition of $\mathrm{Zr}$ and $\mathrm{Fe}$ improves $\beta$-phases; for quaternary alloys it is about $100 \%$ which is tabulated in 4.9 .

Mo is mainly act as $\beta$-stabilizer and when $7.5 \mathrm{wt} \%$ or more with Ti-10Zr was added, $\beta$ phase retained with a bcc crystal structure, which confirmed by XRD pattern of Ti-10Zr and Ti-10Zr-xMo alloys (Ho, Wu, Kuang, et al., 2012). XRD results of Ti$15 \mathrm{Zr}-12.5 \mathrm{Mo}$ only exhibited peaks of $\beta$-phase which confirmed by Correa et al. (Correa et al., 2018). Ti-12Mo-6Zr are strongly affected by the addition of Fe which is discussed in my previous articles (Mohan et al., 2017), when \% of Fe addition is $3 \%$ or more mainly phases are $\beta$ phase (BCC crystal structure), it confirms the $\beta$ phase stability of Fe; which also shown in figure 4.6. From the analysis of Ti-xMo alloys, only $\alpha$-phase is observed in the XRD pattern when the Mo content is $5 \%$, when the Mo content is $10 \%$ both $\alpha$ and $\beta$ phases are found and when the Mo contents are 15 and $20 \%$, only $\beta$ phase are found (Chen et al., 2006).

$\beta$-phases is confirmed by XRD analysis in each alloys Ti-15Mo,Ti-15Mo-5Zr, Ti$15 \mathrm{Mo}-1 \mathrm{Fe}$ and Ti-15Mo-5Zr-1Fe but the athermal $\omega$ phase is not found (Min et al., 2008). Micro-structure of CP Ti consisted of single-phase $\alpha$ grains and the XRD patterns also confirmed that the micro-structure of Ti-35Nb-5.7Ta-7.2Zr consists of $\beta$-phase (Majumdar, Singh and Chakraborty, 2008).

$\mathrm{XRD}$ pattern of the as cast Zr-12Mo-xTi alloys, it is found that the solid-state phase of all samples at room temperature is of $\beta$-type $\mathrm{Zr}$. It should also be clear that $\mathrm{Ti}, \mathrm{Zr}$ and Mo have same structure type, space group and similar crystal lattice, which signifies that all elements maybe completely dissolved each other and form the metastable $\beta$-phase at high temperature (Nie et al., 2014).

For homogenised the elements inside the alloy we switch to mechanical mixing procedure. Fluidity of the mechanical alloying powders with short milling time is possible in some of the cases but with PCA; fluidity is not possible. Fluidity of the Ti-15Mo and Ti-15Mo-6Zr-2Fe powders are $1.17 \mathrm{gr} / \mathrm{sec}$ and $1.27 \mathrm{gr} / \mathrm{sec}$; shown in table 4.15. Fluidity is the basic analysis of powders for suitability of industrial uses due to its roundness of particle. Fluidity with $180 \mathrm{rpm}$ and $52 \mathrm{~min}$ is best for both the alloys. Fluidity with PCA and higher time is more in case of $6 \mathrm{~h}$ but with $24 \mathrm{~h}$ milling time fluidity calculation is not possible due to irregular particles with more time. Due to this, we selected for further analysis with this parameter. flowability of $\mathrm{Ti}, \mathrm{Fe}, \mathrm{Zr}$ and $\mathrm{Al}$ powder after mechanical alloying from $8 \mathrm{~h}-48 \mathrm{~h}$ is not found, it's maybe due to humidity of the powder (Chandrasekaran and Xia, 2005). 
Granulometry of mixed powder is also basic parameters to understand the powder quality. Particle size of milled powder is minimum in case of $180 \mathrm{rpm}$ and $45 \mathrm{~min}$, and the average particle size in this case is $32.18 \mu \mathrm{m}$ (shown in figure 4.11). Normally it is found that with same milling speed if we increase milling time the particle size increases and also same for milling speed increase cause more particle size it's may be due to alloy particle do agglomeration cause of more particle size which is also confirmed by Hsu et al. (Hsu et al., 2013) who worked with Ti-7.5Mo; he claimed with $3 \mathrm{~h}-15 \mathrm{~h}$ milling time particle size is in range of 33.12 and $29.85 \mu \mathrm{m}$ and with $30 \mathrm{~h}$ of milling time particle size became $110.12 \mu \mathrm{m}$. Powder utility (listed in table 4.22) with higher milling time is very less it's due to more heat generated and more welding with inter-particles and jars. Higher milling time have more oxygen contamination and more metallic welding; due to this powder recovery is less with higher milling time which also confirmed by Nouri et al. (Nouri, Hodgson and Wen, 2011).

Lower milling time (6h) have less agglomeration in comparison to higher milling time (24h) shown in figure 4.13, it's mainly due to more particle inter-reaction with each other by higher milling time. Plastic deformation and cold welding is done with higher milling time. Particle distribution is almost homogeneous with lower milling time (tabulated in 4.25) but with higher milling time more $\mathrm{Zr}$ particles are agglomerated with each other. Higher milling time causes more agglomeration which also confirmed by Hosseini et al. (Hosseini-Gourajoubi et al., 2015). Cold welding and agglomeration are major elements during higher milling time which also confirmed by Nouri et al. (Nouri, Hodgson and Wen, 2011; Wang et al., 2016).

Green density for most of the samples are in range of (74.66-78.92) \%. More milling time have normally lower relative green density and also lower sintered density listed in table 4.17,4.20 and 4.26, it's maybe due to higher milling time causes more energy with the powder which creates more friction and more inter-particles collision (Nazari, Nouri and Hilditch, 2015) by which agglomerated particles can't move and deform effectively which inhibit dense packing. Sintered samples with higher milling time have normally lower sintered density which is due to higher milling time have larger particle size; lower milling time have less particles size which have close power particles which accelerates diffusion during sintering process and improves relative sintered density (Hsu et al., 2013).

Bending strength of Ti-15Mo sintered alloy is maximum with lower milling time like with $180 \mathrm{RPM}$ and $45 \mathrm{Min}$ which is $1597 \mathrm{MPa}$ and with $180 \mathrm{rpm}-52 \mathrm{~min}$ the 
value of bending strength is $1261 \mathrm{MPa}$ but this value is lower in comparison with elemental blend alloys. Addition of $\mathrm{Fe}$ and $\mathrm{Zr}$ reduces the value of bending strength of ternary alloy and quaternary alloy with the same milling condition shown in table 4.17 and 4.20. Bending strength for Ti-15Mo-6Zr is $1167 \mathrm{MPa}$ and with addition of (2 and 4) \% Fe; bending strength decreases more; the value is 667.6 and $476.3 \mathrm{MPa}$ respectively. This property is like elemental blend sintered samples. Increment in milling time with PCA reduced the value of bending strength listed in 4.26. Higher milling time decreases yield strength, it's may be due to less packing density and agglomeration phenomena occurs which is also confirmed by Nazari et al. (Nazari, Nouri and Hilditch, 2015).

Hardness value of MA samples is in range of (180.6-183.8) HV with $180 \mathrm{rpm}-52$ min. Minimum value is for Ti-12Mo-6Zr and maximum is for Ti-15Mo-6Zr. Ti-Mo alloys with hot pressing have microhardness value of $460 \mathrm{HV}_{0.3}$ which is triple to Tia $180 \mathrm{HV}_{0.3}$ confirmed by Sochacka et al. (Sochacka, Miklaszewski and Jurczyk, 2019). More milling causes more hardness due to more strength hardening in this case which also confirmed by Nouri et al. (Nouri, Hodgson and Wen, 2011) who worked with Ti-16Sn-14nb with $10 \mathrm{~h}$ and $20 \mathrm{~h}$ milling time and he claimed $40 \%$ more hardness when he increased time from $10 \mathrm{~h}-20 \mathrm{~h}$.

Elastic modulus is a major mechanical property for biomaterials. Elastic modulus is minimum in case of Ti-15Mo with $300 \mathrm{rpm}-52 \mathrm{~min}(62.90 \mathrm{GPa})$ which is better for our uses and with $\mathrm{Zr}$ and $\mathrm{Fe}$ addition the value increase which causes more elastic modulus to like for Ti-15Mo-6Zr-2Fe with $180 \mathrm{rpm}-45 \mathrm{~min}$ have $76.89 \mathrm{GPa}$. Higher milling time have no significant effects on elastic modulus but with higher ball size (10mm dia.), the elastic modulus is little bit less $89.32 \mathrm{GPa}$. The range of elastic modulus of Ti-7.5Mo with different milling time is very less (0.5-3.75) GPa claimed by (Hsu et al., 2013). $\mathrm{Al}-4 \mathrm{Cu}, \mathrm{Al}-4 \mathrm{Cu} / 2 \mathrm{TiO} \mathrm{O}_{2}$ and $\mathrm{Ti}-4 \mathrm{Cu} / 8 \mathrm{Ti0} 0_{2}$ with $300 \mathrm{rpm}-16 \mathrm{~h}$ have elastic modulus increasing with higher $\mathrm{Ti}_{2}$ have more elastic modulus claimed by (Ashuri and Hassani, 2014). By increasing Mo\% the value of elastic modulus is more as claimed by Sochacka et al. (Sochacka, Miklaszewski and Jurczyk, 2019).

For achieving $100 \%$ sintered density we must move to move from mechanical alloying to Spark Plasma Sintering (SPS) process. So, for this process we are using mechanically alloyed powder with $180 \mathrm{rpm}-52 \mathrm{~min}$. From table 4.27, it is shown that sintered density of Ti-15Mo-6Zr with $1200{ }^{\circ} \mathrm{C}$ sintering temperature is maximum which is $98.57 \%$ as shown in figure 5.11 and for other alloy with different condition (alloy and sintering temperature) is also in range of (97.24-98.57) \%. 


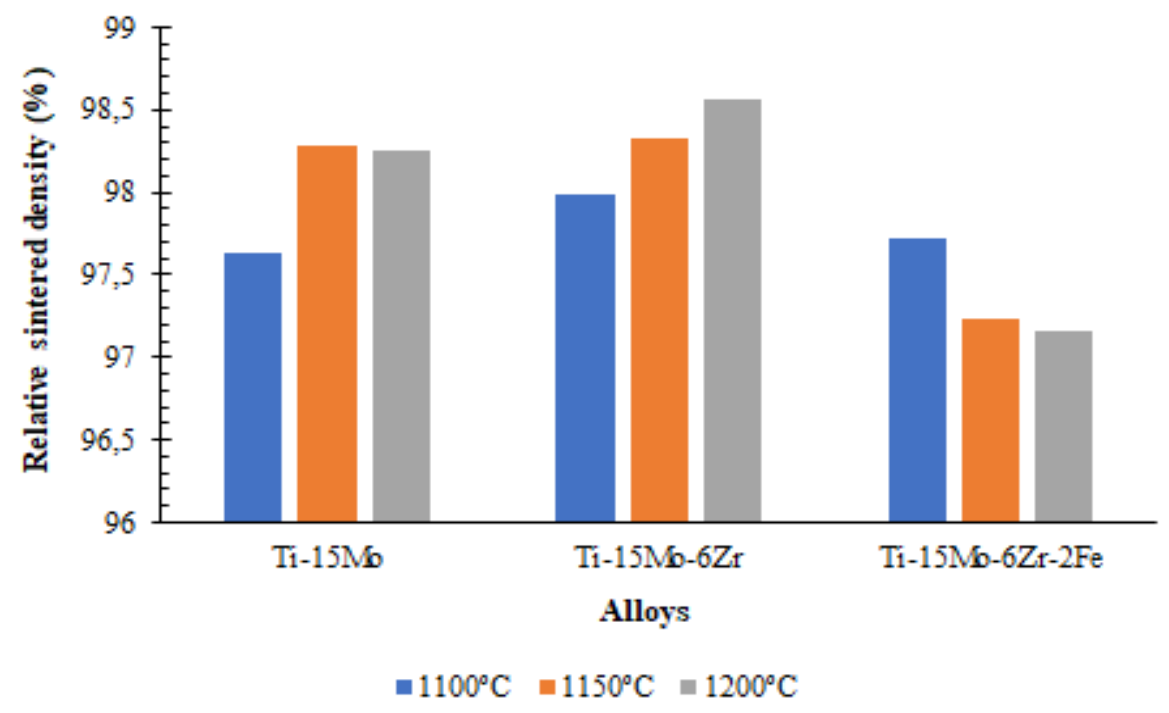

Figure 5.11: Relative sintered density of SPS samples with different sintering samples

Normally relative density increases with sintering temperature for a fixed time (5 min.) and pressure (77 MPa). The maximum relative density of $99.5 \%$ should reached for Mo samples at a sintering temperature $1950{ }^{\circ} \mathrm{C}$ (Mouawad et al., 2012).

Relative density of $\mathrm{Cu}-\mathrm{Cr}$ composites is in range of (94.7-95.4) \% which is lower than pure $\mathrm{Cu}(97.6 \%)$ and they also confirmed that by increasing the sintering temperature higher densification can obtained (Fang et al., 2015). Al-15w\% boron carbide-1.5\% Co alloy produced by SPS method have $(99.3 \pm 0.8) \%$ relative sintered density in comparison to theoretical density (Ghasali, Alizadeh and Ebadzadeh, 2016)\%. Ti-35Nb-7Zr with $1050{ }^{\circ} \mathrm{C}$ sintering temperature, $40 \mathrm{MPa}$ and 5 Minutes holding time have relative sintered density $99.5 \%$ claimed by $\mathrm{HE}$ et al.(HE et al., 2017). Ti-6Al-4V with 50MPa, $10 \mathrm{~min}$. holding time and $1000{ }^{\circ} \mathrm{C}$ have relative sintering density $99.54 \%$ claimed by Eso et al. (Eso, Ranti and Victoria, 2019). Higher sintering have more relative sintered density for Ti-Al-Mo-Si-Ni alloy as claimed by Kanyane et al. (Kanyane et al., 2019) and he also claimed that with higher sintering temperature hardness value is more due to higher sintered density.

Bending strength of Ti-15Mo is higher (1006 MPa) with sintering temperature 1150 ${ }^{\circ} \mathrm{C}$. Addition of $\mathrm{Zr}$ and Fe decreases the value of bending strength which is clearly shown by figure 5.12. Bending strength of Ti-15Mo-6Zr-2Fe has value of $301 \mathrm{MPa}$ 
with $1200{ }^{\circ} \mathrm{C}$ which is almost $70 \%$ less than value of Ti-15Mo. Bending strength is lesser due to carbon deposit on upper layer of surface. With increasing temperature bending strength decreases but with medium sintering temperature $1150^{\circ} \mathrm{C}$ has more bending strength in case of Ti-15Mo and Ti-15Mo-6Zr. Addition of $\mathrm{Zr}$ to Ti-15Mo reduces bending strength to $40 \%$. Lower relative sintered density also have less bending strength which also confirmed by Feng et al. (Feng et al., 2004) who worked with $10 \%$ TiB reinforcement.

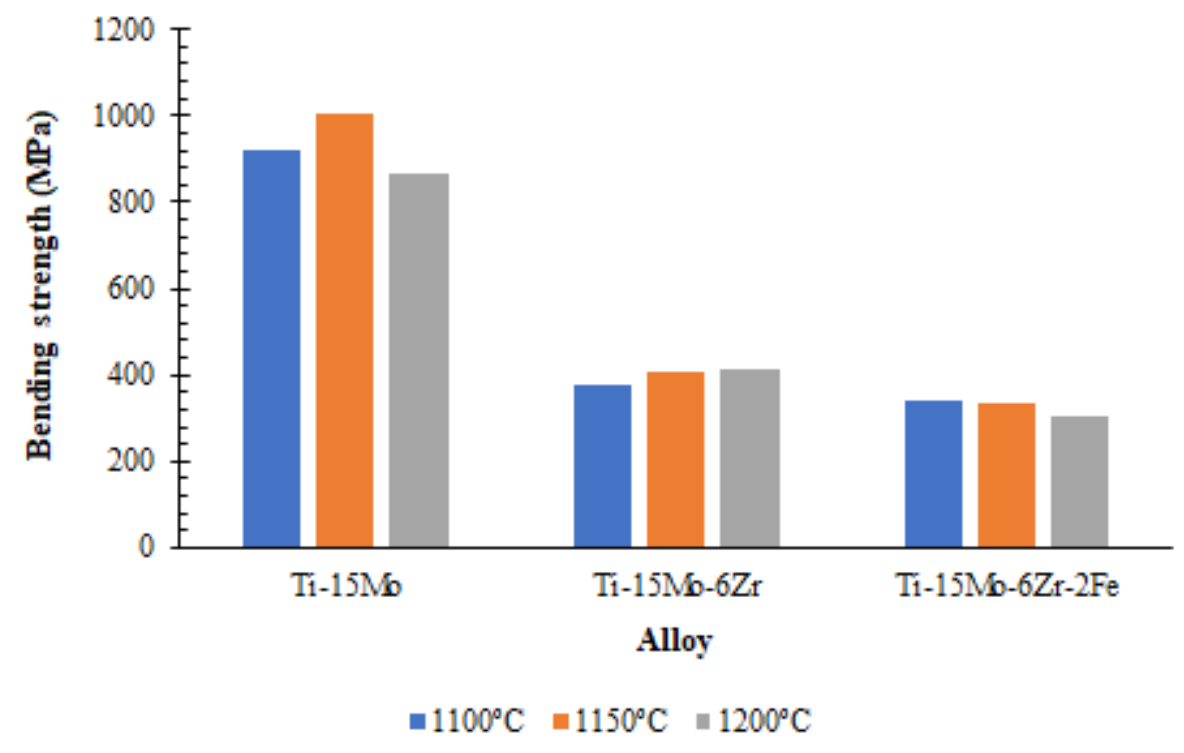

Figure 5.12: Bending strength of SPS samples with different sintering samples

Compressive flexural strength of Ti-6Al-4V with $1000^{\circ} \mathrm{C}, 50 \mathrm{MPa}$ compaction pressure and 5 min holding time is $1414 \mathrm{MPa}$, he claimed with higher compaction pressure strength increases (Garbiec, Siwak and Mróz, 2016). Bending strength with elemental blend is more in comparison to both mechanical alloying and spark plasma sintering process for same alloy.

Elastic modulus for Ti-15Mo with SPS is minimum among all the alloys which is 88.24 GPa. Addition of $\mathrm{Zr}$ and $\mathrm{Fe}$ reduces the value of elastic modulus shown in figure 5.13. Maximum value is for Ti-15Mo-6Zr-2Fe with $1100^{\circ} \mathrm{C}$ which is $106 \mathrm{GPa}$ approx. Normally higher sintering temperature reduces elastic modulus but here in some cases it's not suitable. Some authors used less sintering temperature of $600{ }^{\circ} \mathrm{C}$, 
less holding time ( 3 minutes) and less compaction pressure for reduced the elastic modulus of Ti-alloy with SPS process which is 16-18 GPa claimed by Kon et al. (Kon, Hirakata and Asaoka, 2004). Ti-Fe-Mo-B with $1000{ }^{\circ} \mathrm{C}$ sintering temperature, $20 \mathrm{MPa}$ pressure with SPS process have elastic modulus $137 \mathrm{GPa}$ claimed by Feng et al.(Feng et al., 2004).

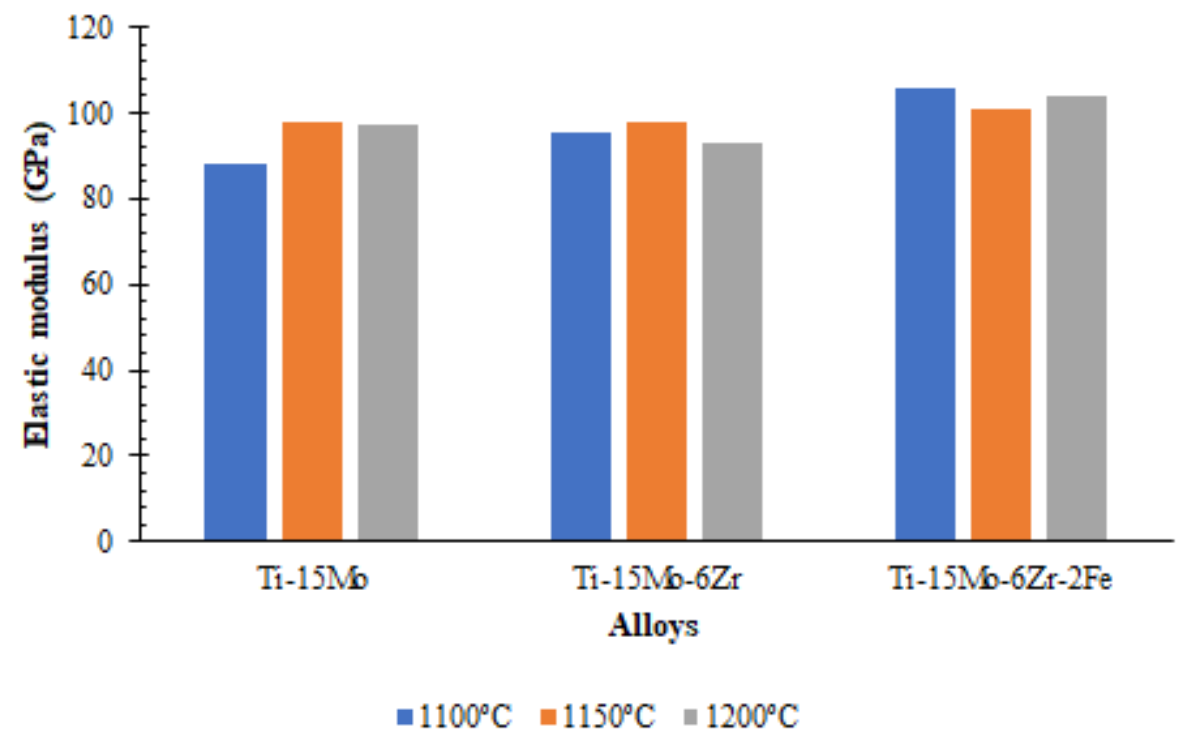

Figure 5.13: Elastic modulus of SPS samples with different sintering samples

Hardness value normally increases with addition of $\mathrm{Zr}$ and $\mathrm{Fe}$ shown in figure 6.21. Increasing in sintering temperature also improves hardness which may be due to strength hardening effect with higher sintering temperature. Hardness of Ti-15Mo is minimum which is $275 \mathrm{HV}$ with $1100^{\circ} \mathrm{C}$ and maximum is for Ti-15Mo- $6 \mathrm{Zr}-2 \mathrm{Fe}$ which is $477 \mathrm{HV}$ with sintering temperature $1150^{\circ} \mathrm{C}$. Hardness values slightly decreases with increasing in sintering temperature which claimed by Mouawad et al.(Mouawad et al., 2012) who worked with Mo by SPS process $\left(1850^{\circ} \mathrm{C}\right.$ sintering temperature, $30 \mathrm{~min}$ holding time and $77 \mathrm{MPa}$ pressure). In our case also sintering temperature $1200{ }^{\circ} \mathrm{C}$ have lesser hardness in comparison with other but with Ti$15 \mathrm{Mo}-6 \mathrm{Zr}-2 \mathrm{Fe}$, it's not valid. Some authors claimed that with lower sintering temperature less presence of $\alpha$-phase is more and with higher temperature more $\beta$ phase found and very little $\alpha$-phase found; due to higher $\beta$-phase the value of micro- 
hardness is more (Bhushan et al., 2018). Microhardness of Ti-6Al-4V with addition to Ni-Ta have higher micro-hardness ( 389 to $480.2 \mathrm{HV0.1}$ ), it may be due to uniform distribution of reinforced particles inside the sintered alloy (Eso, Ranti and Victoria, 2019).

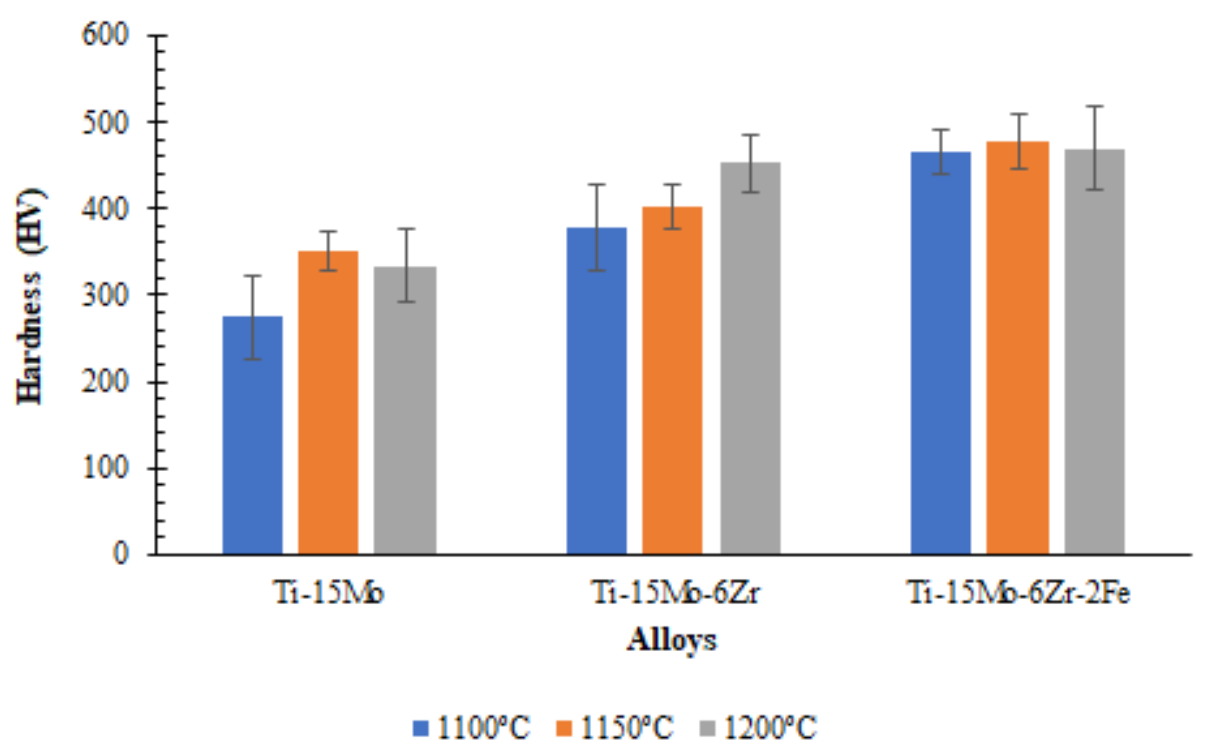

Fig.5.14: Hardness of SPS samples with different sintering samples

From the XRD analysis it is known that sintered samples of Ti-15Mo and Ti-15Mo$6 \mathrm{Zr}$ have both $\alpha$ and $\beta$ phases shown in figure 4.15. Higher sintering temperature have more $\beta$ phases in comparison to lower sintering temperature with both samples with different sintering temperatures and some authors also confirmed this (Bhushan et al., 2018) who worked with Ti-Nb-Zr-Ta.

EBSD analysis is important to know morphological character, grain structure, orientation etc. From the analysis for all alloys Ti-15Mo, Ti-15Mo-6Zr and Ti$15 \mathrm{Mo}-6 \mathrm{Zr}-2 \mathrm{Fe}$ with $1150{ }^{\circ} \mathrm{C}$ have higher $\beta$-phases in all cases. Due to highest $\beta$ phase present with sintering temperature $1150{ }^{\circ} \mathrm{C}$; mechanical properties are better with this temperature in most of the cases. Grain size with SPS process is lower in comparison with other process and mostly have only $\beta$-phase. The value is in range of (4.88-6.8) $\mu \mathrm{m}$; tabulated in table 4.31. Fe-14Cr-0.25Y2O3-0.4Ti by SPS process with $1150{ }^{\circ} \mathrm{C}$ sintering temperature, 5 Minutes holding time have irregular grain 126 |Page 
structure with average grain size by EBSD techniques is in range of $(0.5-15) \mu \mathrm{m}$ claimed by Huang et al. (Huang et al., 2017) and it's similar to our results with EBSD.

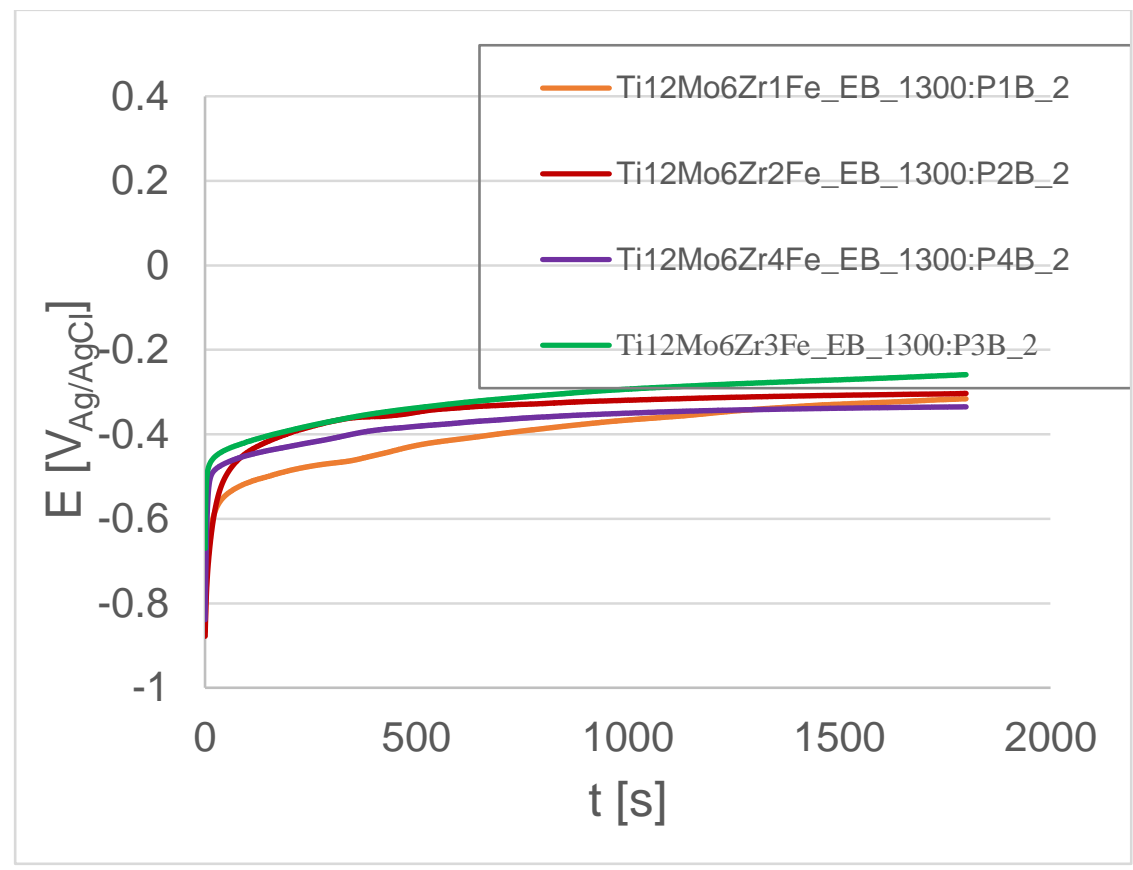

Fig.5.15: $\mathrm{E}_{\mathrm{Corr}}$ of $\mathrm{EB}$ samples with $1300{ }^{\circ} \mathrm{C}$ sintering samples

$\mathrm{I}_{\text {corr }}, \mathrm{E}_{\text {corr }}$ calculated by potentiodynamic test tabulated in table 4.32 and for all of our samples $\mathrm{I}_{\text {corr }}\left(4.08 \cdot 10^{-6}\right.$ to $\left.2.15 \cdot 10^{-8} \mathrm{~A} / \mathrm{cm}^{2}\right)$ and $\mathrm{E}_{\text {corr }}(-0.13$ to $-0.59 \mathrm{~V})$ low in comparison to crystalline $\left.\mathrm{Ti}\left(\mathrm{I}_{\text {corr }}=1.49 \cdot 10^{-5}\right) \mathrm{A} / \mathrm{cm}^{2}, \mathrm{E}_{\text {corr }}=-0.47 \mathrm{~V}\right)$ and for Ti-6Al$4 \mathrm{~V}\left(\mathrm{I}_{\text {corr }}=1.06 \cdot 10^{-5} \mathrm{~A} / \mathrm{cm}^{2}, \mathrm{E}_{\text {corr }}=-0.46 \mathrm{~V}\right.$ ) (Niespodziana, Jurczyk and Jurczyk, 2008) which signifies that our alloy is more corrosion resistant in comparison to pre $\mathrm{Ti}$ and Ti-6Al-4V. With increasing Fe with same sintering temperature $\left(1300{ }^{\circ} \mathrm{C}\right)$ the value of $\mathrm{I}_{\text {corr }}$ decreases which means addition more Fe makes the samples more corrosion resistant. $\mathrm{E}_{\text {corr }}$ with higher $\%$ of $\mathrm{Fe}$ also decreases but with $3 \mathrm{Fe}$ (shown in figure 5.15); the value is least which makes it more suitable. SPS samples have less $\mathrm{I}_{\text {corr }}$ and $\mathrm{E}_{\text {corr }}$ in comparison to other process like EB and MA which make SPS more corrosion resistant and more suitable alloy for biomedical application. Result by (MA + PCA) have inferior results with comparison to other results. Samples with higher $\beta$-phase have more corrosion resistance which also can be seen in our results and it's also confirmed by Nishimura (Nishimura, 2011); who worked with 3Mo- 
$5 \mathrm{Fe}-\mathrm{Ti}$ and have OCP value is in range of $(0.24-0.25) \mathrm{V}$ and for our alloy with SPS process have $-0.13 \mathrm{~V}$ which is very high than pure $\mathrm{Ti}(-0.71 \mathrm{~V})$ which makes our alloys more corrosion results due to less $\mathrm{I}_{\text {corr }}$, more $\mathrm{E}_{\text {corr }}$ and higher OCP.

Ti-10Zr-5Nb-5Ta with casting process have $\mathrm{E}_{\text {corr }}(-0.45 \mathrm{~V})$; which is less than our alloy which is in range of (-0.13 - 0.59) V,(Raducanu et al., 2011) mostly alloys have more value but mechanical alloying process with PCA have less value and $\mathrm{I}_{\text {corr }}$ $\left(6.5 \cdot 10^{-5}\right)$ which is more than our alloys $\left(4.08 \cdot 10^{-6}\right.$ to $\left.2.15 \cdot 10^{-8} \mathrm{~A} / \mathrm{cm}^{2}\right)$; our alloys are more suitable for biomedical application. For Ti-15Mo with different concentration of fluoride ions have $\mathrm{I}_{\text {corr }}$ is in range of $\left(3.1 \cdot 10^{-7}\right)$ and $\mathrm{E}_{\text {corr }}$ is in range of $(-0.275$ V)(Kumar and Narayanan, 2008) which is comparable to our results; which can be better alternative for dental implants.

Addition of more $\mathrm{Fe}$ (1-3) w\% increases ion release rate of Ti which is not good for the biomedical application which is also discussed by Raducanu et al. (Raducanu et al., 2011) but with $2 \mathrm{Fe}$ by elemental blend with $1300^{\circ} \mathrm{C}$ have less ion release rate in comparison to $2 \mathrm{Fe}$. SPS have less ion release rate in comparison to mechanical alloying samples which make SPS process more suitable for biomedical applications. Samples with MA+PCA have very higher ion release rate which is not good for biomaterial. 


\section{Chapter 6: Conclusion}

\section{1: By Elemental Blend (EB) process:}

- Porosity is significantly lower at the higher sintering temperature $\left(1300^{\circ} \mathrm{C}\right)$, More $\%$ of $\mathrm{Fe}$ for Ti-12Mo-6Zr-xFe $(\mathrm{x}=1,2,3,4)$ means more porosity.

- Bending strength for binary (Ti-Mo) alloys is larger than in ternary (Ti$12 \mathrm{Mo}-6 \mathrm{Zr}$ ) and quaternary alloys ( $\mathrm{Ti}-12 \mathrm{Mo}-6 \mathrm{Zr}-\mathrm{xFe}$ ). In case of quaternary alloys (Ti-12Mo-6Zr-xFe $(\mathrm{x}=1,2,3,4)$; more $\%$ of $\mathrm{Fe}$ have less bending strength with both sintering temperatures $\left(1250{ }^{\circ} \mathrm{C}\right.$ and $\left.1300^{\circ} \mathrm{C}\right)$.

- Hardness for quaternary alloys is higher comparison to binary and ternary alloys. With higher \% of Fe the value of hardness is decreasing.

- Quaternary alloys have least elastic modulus in comparison to binary and ternary alloys.

- Grain size of the sintered samples are in the range of (60-81) $\mu \mathrm{m}$ with optical microscopy method but with EBSD method grain size minimized to $10 \mu \mathrm{m}$. Grain size is higher with optical microscopy due to grain size measured only by grain boundary but with EBSD grains measured inside the grains also like sub-grains, so value is low in comparison to optical microscopy.

- Fractography character of the sintered surface is of mixed type (ductile+ brittle).

- Fe acts as $\beta$-stabilizing element, Quaternary alloys have highest $\beta$-phase; for Ti-12Mo-6Zr-3Fe $\beta$-phase is (98.92\%) which is almost $100 \%$, For Ti-12Mo $\alpha$-phase $\%$ is 53.7 and $\beta$-phase $\%$ is 46.3 and for Ti- $15 \mathrm{Mo} \alpha$-phase $\%$ is 50.61 and $\beta$-phase $\%$ is 49.39 it shows that binary alloys have mixed type of structure $(\alpha+\beta)$ which is confirmed by XRD analysis; 
Development of new high-performance Titanium alloys with Fe-addition for dental implants

- From the EBSD analysis of the samples, it is confirmed that increasing in sintering temperature improves $\beta$-phase \% significantly.

\section{2: By Mechanical alloying (MA) process:}

- Mechanical alloying samples have more porosity in comparison to elemental blend samples; it's due to plastic deformation occurring in mechanical alloying samples which don't allow proper compaction of the milling powders and also there is problem in diffusion of particles between each other during sintering process which causes more porosity.

- Fluidity is maximum with milling speed $180 \mathrm{rpm}$ and milling time $52 \mathrm{~min}$ without process control agent (PCA); which makes it suitable for industrial application and further analysis.

- Particle size $\left(\mathrm{D}_{0.5}\right)$ is minimum with milling speed $180 \mathrm{rpm}$ and milling time $52 \mathrm{~min}$ without process control agent (PCA); which is $47.73 \mu \mathrm{m}$ for Ti-12Mo milling powder. Particle size with higher milling time and with process control agent (PCA) is very high $(489 \mu \mathrm{m})$ which may be due to more agglomeration.

- Porosity is maximum with milling speed $300 \mathrm{rpm}$ and milling time $52 \mathrm{~min}$ without process control agent (PCA) which is approx. $17.64 \%$ within all the milling combination and for more porosity elastic modulus and bending strength is also minimum within all samples with this condition.

- Bending strength and hardness is lower for MA samples in comparison to EB process. For Ti-15Mo with EB process bending strength is $2161 \mathrm{MPa}$ but with MA for different combination of milling speed and milling time the maximum value is $1597 \mathrm{MPa}$. Hardness value for $\mathrm{EB}$ process is in range of (283-542) HV but for MA process value is in range of (180-183) HV. 
- Normally elastic modulus is lower for MA samples in comparison to EB process (approx. 20-25\%); it's maybe due to higher porosity of MA sintered samples in comparison to EB sintered samples.

\section{3: By Spark plasma sintering (SPS) process:}

- Spark plasma sintering (SPS) process have very less porosity (1-2) \% in comparison to elemental blend (2-3.5) \% and Mechanical alloying sintered samples (8-17.64).

- Bending strength for Ti-15Mo with $1150{ }^{\circ} \mathrm{C}$ sintering temperature have highest bending strength (1006 MPa) among all SPS samples. Ti-15Mo-6Zr and Ti-15Mo-6Zr-2Fe have very less bending strength in comparison to Ti$15 \mathrm{Mo}$.

- Elastic modulus is minimum $(88.24 \mathrm{GPa})$ for Ti- $15 \mathrm{Mo}$ with $1100^{\circ} \mathrm{C}$ within all the SPS samples.

- Hardness for Ti-15Mo alloy is less in comparison to Ti-15Mo-6Zr and Ti$15 \mathrm{Mo}-6 \mathrm{Zr}-2 \mathrm{Fe}$. Ti-15Mo-6Zr-2Fe with $1150^{\circ} \mathrm{C}$ have highest microhardness (477 HV).

- By EBSD analysis, it is confirmed that for Ti-15Mo-6Zr-2Fe with $1100^{\circ} \mathrm{C}$ have $99.95 \%$ (almost $100 \%$ ) $\beta$-phase.

\section{4: From corrosion test:}

- Addition of $\mathrm{Fe}$ makes quaternary alloys (Ti-12Mo-6Zr) more corrosion resistant; for example,Ti-12Mo-6Zr-4Fe sintered at $1250^{\circ} \mathrm{C}$ have least $\mathrm{I}_{\text {corr }}$ $\left(1.71 \cdot 10^{-8} \mathrm{~A} / \mathrm{cm}^{2}\right)$, higher $\mathrm{E}_{\text {corr }}(-0.11 \mathrm{~V})$, higher Open circuit potential($0.18 \mathrm{~V})$ and lower corrosion velocity $(0.13 \mu \mathrm{m} /$ year $)$ which makes this alloy more corrosion resistant and for this reason this alloy may be a promising alloys for bio-medical applications. 
- EB process have more corrosion resistant in comparison to MA samples and even in some cases it's better in comparison to SPS. But overall SPS process have more corrosion resistance in comparison to EB and MA process which make SPS process more suitable for biomedical application. Within SPS process for Ti-15Mo-6Zr at $1150{ }^{\circ} \mathrm{C}$ sintering temperature samples have better corrosion behavior in comparison to other procedure i.eleast $\mathrm{I}_{\text {corr }}$ $\left(2.15^{*} 10^{-8} \mathrm{~A} / \mathrm{cm}^{2}\right)$, higher $\mathrm{E}_{\text {corr }}(-0.13 \mathrm{~V})$, higher Open circuit potential ($0.14 \mathrm{~V})$ and lower corrosion velocity $(0.17 \mu \mathrm{m} / \mathrm{year})$ which is comparable to Ti-12Mo-6Zr-4Fe alloy with EB method at $1250{ }^{\circ} \mathrm{C}$ sintering temperature.

- So overall Ti-15Mo-6Zr with SPS method at $1150^{\circ} \mathrm{C}$ sintering temperature and Ti-12Mo-6Zr-4Fe alloy with EB method at $1250^{\circ} \mathrm{C}$ sintering temperature have better corrosion resistant which make this both alloy suitable for biomedical application.

- SPS have lesser ion release rate in comparison to MA samples and EB samples; which make SPS process more suitable in comparison to EB and MA process; which is suitable for our alloys. 


\section{Chapter 7: Future Developments:}

Based on the results with different fabrication process with different parameters we can do future advancement of our research:

- We can work with more sintering temperature like $1350^{\circ} \mathrm{C}$ for better results.

- Transmission electron microscopy (TEM) should be performed for some selective samples like Ti-12Mo-6Zr-4Fe and for some SPS samples for detection of hep $\omega$ - phases.

- We can change milling time (18h,30h) and with changing Process control agent (PCA) like calcium $(\mathrm{Ca})$, sodium chloride $(\mathrm{NaCl})$ and wax for better understanding the effect of PCA and to maximize the powder utility and quality of milling powders for mechanical alloying techniques and with this milling powder. We can do SPS process with more alloys like for Ti$12 \mathrm{Mo}, \mathrm{Ti}-12 \mathrm{Mo}-6 \mathrm{Zr}$ and Ti-12Mo-6Zr-4Fe with same sintering temperatures $\left(1100{ }^{\circ} \mathrm{C}, 1150{ }^{\circ} \mathrm{C}\right.$ and $\left.1200{ }^{\circ} \mathrm{C}\right)$, holding time $(5$ minutes $)$ and pressure $(50 \mathrm{MPa})$ for better understanding of this process; because SPS have better results in comparison to elemental blend and mechanical alloying samples.

- We can do in-vitro test (Bio-compatibility test) of some samples like SPS sample of Ti-15Mo- $6 \mathrm{Zr}$ with $1150^{\circ} \mathrm{C}$ sintering temperature and $\mathrm{Ti}-12 \mathrm{Mo}-$ $6 \mathrm{Zr}-4 \mathrm{Fe}$ alloy with $\mathrm{EB}$ method at $1250^{\circ} \mathrm{C}$ sintering temperature due to its better corrosion results. 
Development of new high-performance Titanium alloys with Fe-addition for dental implants

134 |Page 


\section{References}

Abdel-Hady, M., Hinoshita, K. and Morinaga, M. (2006) 'General approach to phase stability and elastic properties of??-type Ti-alloys using electronic parameters', Scripta Materialia, 55(5), pp. 477-480. doi: 10.1016/j.scriptamat.2006.04.022.

Alves, V. A. et al. (2009) 'In situ impedance spectroscopy study of the electrochemical corrosion of $\mathrm{Ti}$ and $\mathrm{Ti}-6 \mathrm{Al}-4 \mathrm{~V}$ in simulated body fluid at $25^{\circ} \mathrm{C}$ and $37{ }^{\circ} \mathrm{C}$ ', Corrosion Science. Elsevier Ltd, 51(10), pp. 2473-2482. doi: 10.1016/j.corsci.2009.06.035.

Ashida, S., Kyogoku, H. and Hosoda, H. (2012) 'Fabrication of Ti-Sn-Cr Shape Memory Alloy by PM Process and its Properties', Materials Science Forum, 706709, pp. 1943-1947. doi: 10.4028/www.scientific.net/MSF.706-709.1943.

Ashuri, H. and Hassani, A. (2014) 'Characterization of severely deformed new composites fabricated by powder metallurgy including a stage of mechanical alloying', Journal of Alloys and Compounds. Elsevier B.V., 617, pp. 444-454. doi: 10.1016/j.jallcom.2014.08.031.

Bao, Y. et al. (2014) 'High strength, low modulus and biocompatible porous Ti???Mo???Fe alloys', Journal of Porous Materials, 21(6), pp. 913-919. doi: 10.1007/s10934-014-9837-0.

Basu, B. (no date) 'Some fundamentals on Spark Plasma Sintering as a processing tool to fabricate Biomaterials', Materials Science, p. 44.

Benjamin, J. (1976) 'Mechanical alloying', Scientific American, pp. 40-48. doi: 10.1016/S0026-0657(00)86280-3.

Bertrand, E. et al. (2010) 'Synthesis and characterisation of a new superelastic Ti25Ta-25Nb biomedical alloy', Journal of the Mechanical Behavior of Biomedical Materials. Elsevier Ltd, 3(8), pp. 559-564. doi: 10.1016/j.jmbbm.2010.06.007.

Bhushan, B. et al. (2018) 'Fabrication and Characterization of a New Range of $\beta$ type Ti-Nb-Ta-Zr-xHaP (x=0, 10) Alloy by Mechanical Alloying and Spark Plasma Sintering for Biomedical Applications', Materials Today: Proceedings. Elsevier Ltd, 5(14), pp. 27749-27756. doi: 10.1016/j.matpr.2018.10.010.

Bolzoni, L. et al. (2013) 'Mechanical behaviour of pressed and sintered CP Ti and 
Development of new high-performance Titanium alloys with Fe-addition for dental implants

Ti-6Al-7 $\mathrm{Nb}$ alloy obtained from master alloy addition powder', Journal of the Mechanical Behavior of Biomedical Materials. Elsevier, 20, pp. 149-161. doi: 10.1016/j.jmbbm.2012.08.022.

Brailovski, V. et al. (2011) 'Bulk and porous metastable beta Ti-Nb-Zr(Ta) alloys for biomedical applications', Materials Science and Engineering C. Elsevier B.V., 31(3), pp. 643-657. doi: 10.1016/j.msec.2010.12.008.

Chandrasekaran, M. and Xia, Z. S. (2005) 'Effect of alloying time and composition on the mechanical properties of Ti alloy', Materials Science and Engineering A, 394(1-2), pp. 220-228. doi: 10.1016/j.msea.2004.11.056.

Chen, Y. Y. et al. (2006) 'Microstructures and properties of titanium alloys Ti-Mo for dental use', Transactions of Nonferrous Metals Society of China (English Edition), 16(SUPPL.), pp. 2-6. doi: 10.1016/S1003-6326(06)60308-7.

Correa, D. R. N. et al. (2016) 'Tribocorrosion behavior of $\beta$-type Ti-15Zr-based alloys', Materials Letters. Elsevier, 179, pp. 118-121. doi: 10.1016/j.matlet.2016.05.045.

Correa, D. R. N. et al. (2018) 'Development of Ti-15Zr-Mo alloys for applying as implantable biomedical devices', Journal of Alloys and Compounds. Elsevier B.V, 749, pp. 163-171. doi: 10.1016/j.jallcom.2018.03.308.

Cui, W. F. and Guo, A. H. (2009) 'Microstructures and properties of biomedical TiNbZrFe??-titanium alloy under aging conditions', Materials Science and Engineering A, 527(1-2), pp. 258-262. doi: 10.1016/j.msea.2009.08.057.

Dai, S. J. et al. (2013) 'Influence of $\mathrm{Zr}$ content on microstructure and mechanical properties of implant Ti-35Nb-4Sn-6Mo-xZr alloys', Transactions of Nonferrous Metals Society of China (English Edition), 23(5), pp. 1299-1303. doi: 10.1016/S1003-6326(13)62597-2.

Dalmau, A. et al. (2015) 'Electrochemical behavior of near-beta titanium biomedical alloys in phosphate buffer saline solution', Materials Science and Engineering $C$. Elsevier B.V., 48, pp. 56-62. doi: 10.1016/j.msec.2014.11.036.

Davis, J. (2003) 'Handbook of Materials for Medical Devices', ASM International, pp. 205-216. doi: 10.1361/hmmd2003p001.

Delvat, E. et al. (2008) 'Microstructure, mechanical properties and cytocompatibility of stable beta Ti-Mo-Ta sintered alloys', Journal of the Mechanical Behavior of Biomedical Materials, 1(4), pp. 345-351. doi: 10.1016/j.jmbbm.2008.01.006. 
Drahansky, M. et al. (2016) 'We are IntechOpen, the world' s leading publisher of Open Access books Built by scientists, for scientists TOP 1\%', Intech, i(tourism), p. 13. doi: http://dx.doi.org/10.5772/57353.

Ekpenyong, C.E., Udokang, N.E., Akpan, E.E., Samson, T. . (2012) 'Double Burden , Non-Communicable Diseases And Risk Factors Evaluation In Sub-Saharan Africa : The Nigerian Experience .', European Journal of Sustainable development, pp. 249270.

Elshalakany, A. B. et al. (2017) 'Microstructure and Mechanical Properties of TiMo-Zr-Cr Biomedical Alloys by Powder Metallurgy', Journal of Materials Engineering and Performance, 26(3), pp. 1262-1271. doi: 10.1007/s11665-0172531-z.

Engineering, A. and York, N. (1994) 'Densification and strengthening of silverreinforced hyd roxya patite- matrix composite prepared by sintering', Scanning, 5, pp. 533-542.

Eso, O., Ranti, S. and Victoria, F. (2019) 'ScienceDirect Synthesis of Ni-Ta on Ti6Al-4V Alloy Using Spark Plasma Sintering', Materials Today: Proceedings. Elsevier Ltd., 18, pp. 2250-2256. doi: 10.1016/j.matpr.2019.07.006.

Fang, Q. et al. (2015) 'Microstructures and mechanical properties of spark plasma sintered $\mathrm{Cu}-\mathrm{Cr}$ composites prepared by mechanical milling and alloying', Materials \& Design. Elsevier Ltd, 88, pp. 8-15. doi: 10.1016/j.matdes.2015.08.127.

Fellah, M. et al. (2015) 'Experimental study of new titanium alloy Ti-6Al-4Fe for biomedical application', pp. 540-550.

Feng, H. et al. (2004) 'Microstructure and mechanical properties of in situ TiB reinforced titanium matrix composites based on Ti-FeMo-B prepared by spark plasma sintering', Composites Science and Technology, 64(16), pp. 2495-2500. doi: 10.1016/j.compscitech.2004.05.013.

Fujita, T. et al. (1996) 'Microstructure and properties of titanium alloy produced in the newly developed blended elemental powder metallurgy process', Materials Science and Engineering A, 213(1-2), pp. 148-153. doi: 10.1016/09215093(96)10232-X.

Gao, Z. et al. (2012) 'Preparation and Characterization of Ti-10Mo Alloy by Mechanical Alloying', Metallography, Microstructure, and Analysis, 1(6), pp. 282289. doi: 10.1007/s13632-012-0045-5. 
Garbiec, D., Siwak, P. and Mróz, A. (2016) 'Effect of compaction pressure and heating rate on microstructure and mechanical properties of spark plasma sintered Ti6Al4V alloy', Archives of Civil and Mechanical Engineering. Politechnika Wrocławska, 16(4), pp. 702-707. doi: 10.1016/j.acme.2016.04.009.

García-Moreno, O. et al. (2011) 'Alumina reinforced eucryptite ceramics: Very low thermal expansion material with improved mechanical properties', Journal of the European Ceramic Society, 31(9), pp. 1641-1648. doi: 10.1016/j.jeurceramsoc.2011.03.033.

Geetha, M. et al. (2009) 'Ti based biomaterials, the ultimate choice for orthopaedic implants - A review', Progress in Materials Science. Elsevier Ltd, 54(3), pp. 397 425. doi: 10.1016/j.pmatsci.2008.06.004.

Ghasali, E., Alizadeh, M. and Ebadzadeh, T. (2016) 'Mechanical and microstructure comparison between microwave and spark plasma sintering of Al-B $<$ inf $>4</$ inf $>C$ composite', Journal of Alloys and Compounds. Elsevier B.V, 655, pp. 93-98. doi: 10.1016/j.jallcom.2015.09.024.

Gordin, D. M. et al. (2005) 'Synthesis, structure and electrochemical behavior of a beta Ti-12Mo-5Ta alloy as new biomaterial', Materials Letters, 59(23), pp. 2959 2964. doi: 10.1016/j.matlet.2004.09.064.

Gordin, D. M. et al. (2010) 'Microstructural characterization of nitrided beta Ti-Mo alloys at $1400{ }^{\circ} \mathrm{C}$ ', Materials Characterization. Elsevier Inc., 61(3), pp. 376-380. doi: 10.1016/j.matchar.2009.12.010.

Guo, S. et al. (2013) 'Microstructural evolution and mechanical behavior of metastable $\beta$-type $\mathrm{Ti}-25 \mathrm{Nb}-2 \mathrm{Mo}-4 \mathrm{Sn}$ alloy with high strength and low modulusMicrostructural evolution and mechanical behavior of metastable $\beta$-type Ti$25 \mathrm{Nb}-2 \mathrm{Mo}-4 \mathrm{Sn}$ alloy with high strength and low modulusr', Progress in Natural Science: Materials International. Elsevier, 23(2), pp. 174-182. doi: 10.1016/j.pnsc.2013.03.008.

Guo, S. et al. (2014) 'Effect of sintering processing on microstructure, mechanical properties and corrosion resistance of Ti-24Nb-4Zr-7.9Sn alloy for biomedical applications', Journal of Alloys and Compounds. Elsevier B.V., 597, pp. 211-216. doi: 10.1016/j.jallcom.2014.01.087.

Hanawa, T. (2006) 'Recent Development of New Alloys for Biomedical Use', Materials Science Forum. Trans Tech Publications Ltd, 512, pp. 243-248. doi: 10.4028/www.scientific.net/MSF.512.243. 
Hao, Y. L. et al. (2007) 'Elastic deformation behaviour of Ti-24Nb-4Zr-7.9Sn for biomedical applications', Acta Biomaterialia, 3(2), pp. 277-286. doi: 10.1016/j.actbio.2006.11.002.

Hatanaka, S. et al. (2010) 'Isothermal Aging Behavior in Ti-10 Cr-Al Alloys for Medical Applications', Advanced Materials Research, 89-91, pp. 232-237. doi: 10.4028/www.scientific.net/AMR.89-91.232.

HE, Z. yuan et al. (2017) 'Mechanical and corrosion properties of Ti-35Nb-7Zr-xHA composites fabricated by spark plasma sintering', Transactions of Nonferrous Metals Society of China (English Edition). The Nonferrous Metals Society of China, 27(4), pp. 848-856. doi: 10.1016/S1003-6326(17)60097-9.

Herr, U. (1995) 'Mechanical Alloying and Milling', Key Engineering Materials, 103, pp. 113-124. doi: 10.4028/www.scientific.net/KEM.103.113.

Ho, W. F. et al. (2009) 'Structure, mechanical properties and grindability of dental Ti-10Zr-X alloys', Materials Science and Engineering C. Elsevier B.V., 29(1), pp. 36-43. doi: 10.1016/j.msec.2008.05.004.

Ho, W. F., Wu, S. C., Hsu, S. K., et al. (2012) 'Effects of molybdenum content on the structure and mechanical properties of as-cast Ti-10Zr-based alloys for biomedical applications', Materials Science and Engineering C. Elsevier B.V., 32(3), pp. 517-522. doi: 10.1016/j.msec.2011.12.003.

Ho, W. F., Wu, S. C., Kuang, H. S., et al. (2012) 'Effects of molybdenum content on the structure and mechanical properties of as-cast Ti-10Zr-based alloys for biomedical applications', Materials Science and Engineering C. Elsevier B.V., 32(3), pp. 517-522. doi: 10.1016/j.msec.2011.12.003.

Ho, W. F., Ju, C. P. and Chern Lin, J. H. (1999) 'Structure and properties of cast binary Ti-Mo alloys', Biomaterials, 20(22), pp. 2115-2122. doi: 10.1016/S01429612(99)00114-3.

Hosseini-Gourajoubi, F. et al. (2015) 'Effect of process control agents on synthesizing nano-structured $2 \mathrm{Mg}-9 \mathrm{Ni}-\mathrm{Y}$ catalyst by mechanical milling and its catalytic effect on desorption capacity of $\mathrm{MgH} 2$ ', Advanced Powder Technology. The Society of Powder Technology Japan, 26(2), pp. 448-453. doi: 10.1016/j.apt.2014.11.017.

Hsu, H.-C. et al. (2013) 'Processing and mechanical properties of porous Ti-7.5Mo alloy', Materials \& Design, 47, pp. 21-26. doi: 10.1016/j.matdes.2012.12.043. 
Huang, Y. et al. (2017) 'Microstructural comparison of effects of hafnium and titanium additions in spark-plasma-sintered Fe-based oxide-dispersion strengthened alloys', Journal of Nuclear Materials. The Authors, 487, pp. 433-442. doi: 10.1016/j.jnucmat.2017.02.030.

I, K. K. W., I, L. J. G. and I, J. H. D. (2017) 'WANG ET AL ./ Ti-12Mo-6Zr-2Fe FOR SURGICAL IMPLANTS', pp. 76-87.

Ikeda, M. et al. (2009) 'Isothermal Aging Behavior of Beta Titanium-Manganese Alloys, Materials Transactions, 50(12), pp. 2737-2743. doi: 10.2320/matertrans.MA200902.

Ikehata, H. et al. (2004) 'First-principles calculations for development of low elastic modulus Ti alloys', Physical Review B, 70(17), pp. 1-8. doi: 10.1103/PhysRevB.70.174113.

Jackson-Leach, R. and Lobstein, T. (2006) 'Estimated burden of paediatric obesity and co-morbidities in Europe. Part 1. the increase in the prevalence of child obesity in Europe is itself increasing', International Journal of Pediatric Obesity, 1(1), pp. 26-32. doi: 10.1080/17477160600586614.

Kanyane, L. R. et al. (2019) 'Synthesis of equi-atomic Ti-Al-Mo-Si-Ni high entropy alloy via spark plasma sintering technique: Evolution of microstructure, wear, corrosion and oxidation behaviour', Results in Physics. Elsevier, 14(March), p. 102465. doi: 10.1016/j.rinp.2019.102465.

Kon, M., Hirakata, L. M. and Asaoka, K. (2004) 'Porous Ti-6Al-4V Alloy Fabricated by Spark Plasma Sintering for Biomimetic Surface Modification', Journal of Biomedical Materials Research - Part B Applied Biomaterials, 68(1), pp. 88-93. doi: 10.1002/jbm.b.20004.

Kumar, S. and Narayanan, T. S. N. S. (2008) 'Corrosion behaviour of Ti-15Mo alloy for dental implant applications', Journal of Dentistry, 36(7), pp. 500-507. doi: 10.1016/j.jdent.2008.03.007.

Kuroda, D. et al. (1998) 'Design and mechanical properties of new $\beta$ type titanium alloys for implant materials', Materials Science and Engineering: A, 243(1-2), pp. 244-249. doi: 10.1016/S0921-5093(97)00808-3.

Kuroda, P. A. B., Buzalaf, M. A. R. and Grandini, C. R. (2016) 'Effect of molybdenum on structure, microstructure and mechanical properties of biomedical Ti-20Zr-Mo alloys', Materials Science and Engineering: C. Elsevier B.V., 67, pp. 
511-515. doi: 10.1016/j.msec.2016.05.053.

Kurtz, S. M. et al. (2007) 'Future clinical and economic impact of revision total hip and knee arthroplasty', Journal of Bone and Joint Surgery - Series A, 89(SUPPL. 3), pp. 144-151. doi: 10.2106/JBJS.G.00587.

Kusano, Y. et al. (2010) 'Phase Constitution and Mechanical Properties of Ti-(Cr, Mn)-Sn Biomedical Alloys', Materials Science Forum, 654-656(October 2015), pp. 2118-2121. doi: 10.4028/www.scientific.net/MSF.654-656.2118.

Kwasniak, P. et al. (2014) 'Influence of oxygen content on the mechanical properties of hexagonal titanium: First principles calculations', Mater. Sci. Engng A, 590(8), pp. 74-79.

Laheurte, P. et al. (2010) 'Mechanical properties of low modulus ?? titanium alloys designed from the electronic approach', Journal of the Mechanical Behavior of Biomedical Materials. Elsevier Ltd, 3(8), pp. 565-573. doi: 10.1016/j.jmbbm.2010.07.001.

Lampman, S. and International, A. S. M. (2018) 'Titanium and Its Alloys for Biomedical Implants', Materials for Medical Devices, 23, pp. 223-236. doi: 10.31399/asm.hb.v23.a0005674.

Li, X. et al. (2015) 'Crystallization kinetics and spark plasma sintering of amorphous Ni53Nb20Ti10Zr8Co6Ta3 powders prepared by mechanical alloying', Vacuum, 114, pp. 93-100. doi: 10.1016/j.vacuum.2015.01.002.

Li, Yuhua et al. (2014) 'New developments of ti-based alloys for biomedical applications', Materials, 7(3), pp. 1709-1800. doi: 10.3390/ma7031709.

Liu, J. et al. (2017) 'Microstructure, mechanical behavior and biocompatibility of powder metallurgy Nb-Ti-Ta alloys as biomedical material', Materials Science and Engineering C. Elsevier B.V., 71, pp. 512-519. doi: 10.1016/j.msec.2016.10.043.

Liu, X. J. et al. (2014) 'The effect of process control agents and ball to powder rations on the electrochemical characteristics of mechanically alloyed $\mathrm{SnS} 2$ anode materials', Powder Technology, 259, pp. 117-124. doi: 10.1016/j.powtec.2014.03.052.

Liu, Y. et al. (2006) 'Design of powder metallurgy titanium alloys and composites', Materials Science and Engineering A, 418(1-2), pp. 25-35. doi: 10.1016/j.msea.2005.10.057. 
Lu, J. W. et al. (2013a) 'Microstructure and beta grain growth behavior of Ti-Mo alloys solution treated', Materials Characterization. Elsevier Inc., 84(96), pp. 105111. doi: 10.1016/j.matchar.2013.07.014.

Lu, J. W. et al. (2013b) 'Microstructure and beta grain growth behavior of Ti-Mo alloys solution treated', Materials Characterization. Elsevier Inc., 84(96), pp. 105111. doi: 10.1016/j.matchar.2013.07.014.

Ma, L. W., Cheng, H. S. and Chung, C. Y. (2013) 'Effect of thermo-mechanical treatment on superelastic behavior of Ti-19Nb-14Zr (at.\%) shape memory alloy', Intermetallics, 32, pp. 44-50. doi: 10.1016/j.intermet.2012.07.024.

Majumdar, P., Singh, S. B. and Chakraborty, M. (2008) 'Elastic modulus of biomedical titanium alloys by nano-indentation and ultrasonic techniques-A comparative study', Materials Science and Engineering A, 489(1-2), pp. 419-425. doi: 10.1016/j.msea.2007.12.029.

Majumdar, S. et al. (2010) 'Preparation of Mo-Ti-Zr-C alloy tube by P/M route', Nuclear Engineering and Design. Elsevier B.V., 240(5), pp. 975-979. doi: 10.1016/j.nucengdes.2009.12.019.

Martins Júnior, J. R. S. et al. (2011) 'Preparation and characterization of Ti-15Mo alloy used as biomaterial', Materials Research, 14(1), pp. 107-112. doi: 10.1590/S1516-14392011005000013.

Martz, E. O. et al. (1997) 'Materials and Design of Spinal Implants-A Review.', Journal of biomedical materials research, 38(3), pp. 267-288. doi: 10.1002/(sici)1097-4636(199723)38:3<267::aid-jbm12>3.0.co;2-8.

Min, X. H. et al. (2008) 'Effect of Fe and $\mathrm{Zr}$ additions on omega phase formation in beta-type Ti-Mo alloys', Materials Science and Engineering A, 497(1-2), pp. 7478. doi: 10.1016/j.msea.2008.06.018.

Min, X. H. et al. (2010) 'Effects of Fe addition on tensile deformation mode and crevice corrosion resistance in Ti-15Mo alloy', Materials Science and Engineering A. Elsevier B.V., 527(10-11), pp. 2693-2701. doi: 10.1016/j.msea.2009.12.050.

Mishnaevsky, L. et al. (2014) 'Nanostructured titanium-based materials for medical implants: Modeling and development', Materials Science and Engineering $R$ : Reports, 81(1), pp. 1-19. doi: 10.1016/j.mser.2014.04.002.

Miura, K. et al. (2011) 'Acta Biomaterialia The bone tissue compatibility of a new $\mathrm{Ti}-\mathrm{Nb}-\mathrm{Sn}$ alloy with a low Young' s modulus', Acta Biomaterialia. Acta 
Materialia Inc., 7(5), pp. 2320-2326. doi: 10.1016/j.actbio.2011.02.008.

Mohammed, M. T. (2014) 'Beta-Titanium-Alloys-The-Lowest-Elastic-Modulusfor-Biomedical-Applications-A-Review', International Journal of Chemical, Nuclear, Materials and Metallurgical Engg, 8(8), pp. 772-77.

Mohan, P. et al. (2017) 'Effect of Fe content, sintering temperature and powder processing on the microstructure, fracture and mechanical behaviours of Ti-Mo-ZrFe alloys', Journal of Alloys and Compounds. Elsevier B.V, 729, pp. 1215-1225. doi: 10.1016/j.jallcom.2017.09.255.

Mouawad, B. et al. (2012) 'Full densification of molybdenum powders using Spark Plasma Sintering', Metallurgical and Materials Transactions A, pp. 1-8. Available at: https://hal.archives-ouvertes.fr/hal-01081684/.

Nag, S. et al. (2005) 'Comparison of microstructural evolution in Ti-Mo-Zr-Fe and Ti-15Mo biocompatible alloys', Journal of Materials Science: Materials in Medicine, 16(7), pp. 679-685. doi: 10.1007/s10856-005-2540-6.

Nag, S., Banerjee, R. and Fraser, H. L. (2007) 'A novel combinatorial approach for understanding microstructural evolution and its relationship to mechanical properties in metallic biomaterials', Acta Biomaterialia, 3(3 SPEC. ISS.), pp. 369-376. doi: 10.1016/j.actbio.2006.08.005.

Nakai, M. et al. (2011) 'Self-adjustment of Young's modulus in biomedical titanium alloys during orthopaedic operation', Materials Letters. Elsevier B.V., 65(4), pp. 688-690. doi: 10.1016/j.matlet.2010.11.006.

Nazari, K. A., Nouri, A. and Hilditch, T. (2015) 'Effects of milling time on powder packing characteristics and compressive mechanical properties of sintered Ti-10Nb3Mo alloy', Materials Letters. Elsevier, 140, pp. 55-58. doi: 10.1016/j.matlet.2014.10.143.

Nie, L. et al. (2014) 'Novel ??-type Zr-Mo-Ti alloys for biological hard tissue replacements', Materials and Design. Elsevier Ltd, 53, pp. 8-12. doi: 10.1016/j.matdes.2013.07.008.

Niespodziana, K., Jurczyk, K. and Jurczyk, M. (2008) 'The synthesis of titanium alloys for biomedical applications', Rev. Adv. Mater. Sci, 18, pp. 236-240. Available at: http://www.ipme.ru/e-journals/RAMS/no_31808/niespodziana.pdf.

Niinomi, M. (1998) 'Mechanical properties of biomedical titanium alloys', Materials Science and Engineering: A, 243(1-2), pp. 231-236. doi: 10.1016/S0921- 
Development of new high-performance Titanium alloys with Fe-addition for dental implants

5093(97)00806-X.

Niinomi, M. (2002) 'Recent metallic materials for biomedical applications', Metallurgical and Materials Transactions A, 33(3), pp. 477-486. doi: 10.1007/s11661-002-0109-2.

Niinomi, M. (2003a) 'Fatigue performance and cyto-toxicity of low rigidity titanium alloy, Ti-29Nb-13Ta-4.6Zr', Biomaterials, 24(16), pp. 2673-2683. doi: 10.1016/S0142-9612(03)00069-3.

Niinomi, M. (2003b) 'Recent research and development in titanium alloys for biomedical applications and healthcare goods', Science and Technology of Advanced Materials, 4(5), pp. 445-454. doi: 10.1016/j.stam.2003.09.002.

Niinomi, M., Nakai, M. and Hieda, J. (2012) 'Development of new metallic alloys for biomedical applications', Acta Biomaterialia. Acta Materialia Inc., 8(11), pp. 3888-3903. doi: 10.1016/j.actbio.2012.06.037.

Nishimura, T. (2011) 'Corrosion resistance of Mo-Fe-Ti alloy for overpack in simulating underground environment', Nuclear Engineering and Design. Elsevier B.V., 241(12), pp. 4745-4749. doi: 10.1016/j.nucengdes.2011.03.032.

Van Noort, R. (1987) 'Titanium: The implant material of today', Journal of Materials Science, 22(11), pp. 3801-3811. doi: 10.1007/BF01133326.

Nouri, A., Hodgson, P. D. and Wen, C. (2011) 'Effect of ball-milling time on the structural characteristics of biomedical porous Ti-Sn-Nb alloy', Materials Science and Engineering C. Elsevier B.V., 31(5), pp. 921-928. doi: 10.1016/j.msec.2011.02.011.

O’Brien, R. C. et al. (2009) 'Spark Plasma Sintering of simulated radioisotope materials within tungsten cermets', Journal of Nuclear Materials. Elsevier B.V., 393(1), pp. 108-113. doi: 10.1016/j.jnucmat.2009.05.012.

Oldani, C. R. and Dominguez, a a (2007) 'Simulation of the mechanical behavior of a HIP implant. Implant fixed to bone by cementation under arbitrary load', Journal of Physics: Conference Series, 90, p. 012007. doi: 10.1088/17426596/90/1/012007.

Oshida, Y. (2013) 10 - Fabrication Technologies, Bioscience and Bioengineering of Titanium Materials (Second Edition). doi: http://dx.doi.org/10.1016/B978-0-44462625-7.00010-8. 
Park, C. H. et al. (2017) 'Multifunctional Beta Ti Alloy with Improved Specific Strength', Shape Memory and Superelasticity. Springer International Publishing, 3(4), pp. 373-380. doi: 10.1007/s40830-017-0124-1.

Raducanu, D. et al. (2011) 'Mechanical and corrosion resistance of a new nanostructured Ti-Zr-Ta-Nb alloy', Journal of the Mechanical Behavior of Biomedical Materials. Elsevier Ltd, 4(7), pp. 1421-1430. doi: 10.1016/j.jmbbm.2011.05.012.

Sabeena, M. et al. (2016) 'Microstructural characterization of transformation products of bec ?? in Ti-15 Mo alloy', Journal of Alloys and Compounds. Elsevier B.V, 658, pp. 301-315. doi: 10.1016/j.jallcom.2015.10.200.

Shen, Z. et al. (2002) 'Spark plasma sintering of alumina', Journal of the American Ceramic Society, 85(8), pp. 1921-1927. doi: 10.1111/j.1151-2916.2002.tb00381.x.

Sochacka, P., Miklaszewski, A. and Jurczyk, M. (2019) 'Development of $\beta$-type Ti$\mathrm{x}$ at. \% Mo alloys by mechanical alloying and powder metallurgy: Phase evolution and mechanical properties $(10 \leq \mathrm{x} \leq 35)$, Journal of Alloys and Compounds. Elsevier B.V, 776, pp. 370-378. doi: 10.1016/j.jallcom.2018.10.217.

Suárez, M., Fernández, a and Menéndez, J. (2013) 'Challenges and Opportunities for Spark Plasma Sintering: A Key Technology for a New Generation of Materials', Sintering Applications, p. 319. doi: http://dx.doi.org/10.5772/53706.

Sugano, D. and Ikeda, M. (2005) 'The effect of aluminum content on phase constitution and heat treatment behavior of Ti-Cr-Al alloys for healthcare application', Materials Science and Engineering C, 25(3), pp. 377-381. doi: 10.1016/j.msec.2005.01.021.

Suryanarayana, C., Ivanov, E. and Boldyrev, V. . (2001) 'The science and technology of mechanical alloying', Materials Science and Engineering: A, 304306, pp. 151-158. doi: 10.1016/S0921-5093(00)01465-9.

Tane, M. et al. (2008) 'Peculiar elastic behavior of Ti-Nb-Ta-Zr single crystals', Acta Materialia, 56(12), pp. 2856-2863. doi: 10.1016/j.actamat.2008.02.017.

Tarzimoghadam, Z. et al. (2015) 'Microstructure design and mechanical properties in a near- $\alpha$ Ti-4Mo alloy', Acta Materialia. Acta Materialia Inc., 97, pp. 291-304. doi: 10.1016/j.actamat.2015.06.043.

Tsai, J. T. et al. (2012) 'Microstructure and properties of Ti-8Mo-12Fe and Ti-8Mo$8 \mathrm{Cu}$ alloys with $\mathrm{Cr} 3 \mathrm{C} 2$ additives produced in the powder metallurgy processes', 
Development of new high-performance Titanium alloys with Fe-addition for dental implants

Procedia Engineering, 36, pp. 368-373. doi: 10.1016/j.proeng.2012.03.054.

Wang, K. (1996) 'The use of titanium for medical applications in the USA', Materials Science and Engineering A, 213(1-2), pp. 134-137. doi: 10.1016/09215093(96)10243-4.

Wang, S. et al. (2016) 'Effect of mechanical alloying on the microstructure and properties of $\mathrm{W}-\mathrm{Ti}$ alloys fabricated by spark plasma sintering', Powder Technology. Elsevier B.V., 302, pp. 1-7. doi: 10.1016/j.powtec.2016.08.039.

Yang, G. and Zhang, T. (2005) 'Phase transformation and mechanical properties of the Ti 50Zr30Nb10Ta10 alloy with low modulus and biocompatible', Journal of Alloys and Compounds, 392(1-2), pp. 291-294. doi: 10.1016/j.jallcom.2004.08.099.

Yang, Y. F. et al. (2012) 'The sintering, sintered microstructure and mechanical properties of Ti-Fe-Si alloys', Metallurgical and Materials Transactions A: Physical Metallurgy and Materials Science, 43(12), pp. 4896-4906. doi: 10.1007/s11661012-1272-8.

Yoda, M. et al. (2001) 'Bond strength of binary titanium alloys to porcelain', Biomaterials, 22(12), pp. 1675-1681. doi: 10.1016/S0142-9612(00)00329-X.

Zardiackas, L. D., Mitchell, D. W. and Disegi, J. a. (1997) 'Characterization of Ti15Mo beta titanium alloy [orthopedic implants]', Proceedings of the 199716 Southern Biomedical Engineering Conference, pp. 95-98. doi: 10.1109/SBEC.1997.583223.

Zardiackas, L. D., Mitchell, I. D. W. and Disegi, J. A. (2017) 'Copyright 91996 by ASTM International www.astm.org', pp. 60-75.

Zhang, W. D. et al. (2015) 'Elastic modulus of phases in Ti-Mo alloys', Materials Characterization. Elsevier Inc., 106, pp. 302-307. doi: 10.1016/j.matchar.2015.06.008.

Zhao, C., Zhang, X. and Cao, P. (2011) 'Mechanical and electrochemical characterization of Ti-12Mo-5Zr alloy for biomedical application', Journal of Alloys and Compounds. Elsevier B.V., 509(32), pp. 8235-8238. doi: 10.1016/j.jallcom.2011.05.090.

Zhao, X. et al. (2012) 'Beta type Ti-Mo alloys with changeable Young's modulus for spinal fixation applications', Acta Biomaterialia. Acta Materialia Inc., 8(5), pp. 1990-1997. doi: 10.1016/j.actbio.2012.02.004. 
Zhentao, Y. and Lian, Z. (2006) 'Influence of martensitic transformation on mechanical compatibility of biomedical ?? type titanium alloy TLM', Materials Science and Engineering A, 438-440(SPEC. ISS.), pp. 391-394. doi: 10.1016/j.msea.2005.12.079. 
Development of new high-performance Titanium alloys with Fe-addition for dental implants

148 |Page 


\section{List of publications:}

\section{Journal papers:}

Mohan, P., Elshalakany, A.B., Osman, T.A., Amigo, V. and Mohamed, A., 2017. Effect of Fe content, sintering temperature and powder processing on the microstructure, fracture and mechanical behaviours of Ti-Mo-Zr-Fe alloys. Journal of Alloys and Compounds, 729, pp.1215-1225.

Journal of Alloys and Compounds 729 (2017) 1215-1225

Contents lists available at ScienceDirect

Journal of Alloys and Compounds

journal homepage: http://www.elsevier.com/locate/jalcom

Effect of Fe content, sintering temperature and powder processing on the microstructure, fracture and mechanical behaviours of Ti-Mo-ZrFe alloys

P. Mohan ${ }^{\text {a }}$, Abou Bakr Elshalakany ${ }^{\text {a, d }}$, T.A. Osman ${ }^{\text {c }}$, V. Amigo a ${ }^{\text {a }}$ Alaa Mohamed ${ }^{\text {b, d, * }}$

a Institute of Materials Technology, Universitat Politècnica de València, Spain

' Egypt Nanotechnology Center, EGNC, Cairo University, 12613 Giza, Egypt

Cairo University, Giza, Egypt

d Production Engineering and Printing Technology Department, Akhbar El Yom Academy, Giza, Egypt

A R T I C L E I N F O

Article history:

Received 4 August 2017

Received in revised form

22 September 2017

Accepted 23 September 2017
Available online 25 September 2017

\section{Keywords:}

Elemental blen

Mechanical alloyin

Biocompatibility

Mechanical properties

\begin{abstract}
A B S T R A C T
The present work studies the effect of iron on the microstructural characterization and mechanical properties of Ti12Mo6ZrxFe alloys that fabricated by two different techniques elemental blend (EB) at $600 \mathrm{MPa}$ and mechanical alloying (MA) at $600 \mathrm{MPa}$ and $900 \mathrm{MPa}$ with different sintering temperatures. The Ti12Mo6ZrxFe ( $x=1,2,3$ and 4 wt.\%) alloys were investigated to develop new biomedical materials used for dental implant application. The microstructure, residual porosity and the mechanical properties of the sintered Ti12Mo6ZrxFe alloys were investigated by using optical microscopy, X-ray diffraction (XRD), Scanning Electron Microscopy (SEM(, Energy dispersive X-ray (EDX), microhardness and bending stress-strain curves. The results indicated that addition of $\mathrm{Zr}$ and a small amount of Fe improves the $\beta$ stress-strain curves. The results indicated that addition of $\mathrm{Zr}$ and a small amount of Fe improves the $\beta$ -
phase stability and improving the properties of Ti-Mo alloy. In addition, with increasing the sintering temperatures, the microstructure became more homogeneous for $\beta$ phase, which decreases in the modulus and strength. The Mechanical alloying allows highly homogeneous composition and particle morphology. Bending strength in EB is much higher than MA techniques. Increasing of compaction pressure during MA technique increases the bending strength and decreases the porosity. Moreover, the Ti12Mo6Zr2Fe alloys exhibited higher bending strength/modulus ratios.
\end{abstract}


Elshalakany, A.B., Ali, S., Mata, A.A., Eessaa, A.K., Mohan, P., Osman, T.A. and Borrás, V.A., 2017. Microstructure and mechanical properties of Ti-Mo-Zr-Cr biomedical alloys by powder metallurgy. Journal of Materials Engineering and Performance, 26(3), pp.1262-1271.

JMEPEG

DOI: $10.1007 / \mathrm{s} 11665-017-2531-z$

\title{
Microstructure and Mechanical Properties of Ti-Mo-Zr-Cr Biomedical Alloys by Powder Metallurgy
}

Abou Bakr Elshalakany, Shady Ali, A. Amigó Mata, Ashraf K. Eessaa, P. Mohan, T.A. Osman, and V. Amigó Borrás

(Submitted May 6, 2016; in revised form January 3, 2017)

\begin{abstract}
Titanium and its alloys have been widely used as biometals due to their excellent biocompatibility, corrosion resistance and moderate mechanical properties. Ti-15Mo-6 Zr-based alloys and a series of Ti-15Mo-6 Zr-xCr $(x=1,2,3,4$ wt. \%) alloys were designed and fabricated by powder metallurgy for the first time to develop novel biomedical materials. The microstructure, internal porosity and mechanical properties of the sintered $\mathrm{Ti}-15 \mathrm{M} 0-6 \mathrm{Zr}$ and $\mathrm{Ti}-15 \mathrm{M} 0-6 \mathrm{Zr}-\mathrm{x} \mathrm{Cr}$ alloys were investigated using scanning electronic microscopy (SEM) and bending and compression tests. The experimental results indicated that the microstructure and mechanical properties of these alloys changed as different $\mathrm{Cr}$ levels were added. The addition of small $\mathrm{Cr}$ levels further increased the $\beta$-phase stability, improving the properties of the $\mathrm{Ti}-15 \mathrm{Mo}-6 \mathrm{Zr}$-x $\mathrm{Cr}$ alloy. However, all of the alloys had good ductility, and the Ti-15Mo-6 $\mathrm{Zr}-2 \mathrm{Cr}$ alloy had lower bending and compression moduli ( 31 and $23 \mathrm{GPa}$, respectively) than the Ti-15Mo-6Zr-based alloys (40 and $36 \mathrm{GPa}$, respectively). Moreover, the Ti-15M0-6Zr-2Cr alloys exhibited higher bending and compression strength/modulus ratios, which were as large as 48.4 and 52.2 , respectively; these were higher than those of the Ti-15Mo-6Zr-based alloy (41.3 and 33.6, respectively). In the search for a better implant material, $\beta$ phase $\mathrm{Ti}-15 \mathrm{Mo}-6 \mathrm{Zr}-2 \mathrm{Cr}$, with its low modulus, ductile properties and reasonably high strength, is a promising candidate.
\end{abstract}




\title{
Conference Papers:
}

Mohan, P., Amigó Mata, A., Elshalakany, A.B., and Amigó, V., July 2015 Effect Of Powder Processing On The Microstructure And Mechanical Properties Of Ti-Mo Alloys. V congreso Nacional de Pulvimetalurgia Girona 2015. 1,2 y 3 de Julio (pp. 388-397)

V Congreso Nacional de Pulvimetalurgia Girona 2015. 1, 2 y 3 de julio

\section{EFFECT OF POWDER PROCESSING ON THE MICROSTRUCTURE AND MECHANICAL PROPERTIES OF TI-MO ALLOYS}

\author{
P.Mohan ${ }^{1}$, A. Amigo ${ }^{1}$, Abou Bakr Elshalakany ${ }^{1,2}$, V.Amigo $^{1}$ \\ ${ }^{1}$ INSTITUTE OF MATERIALS TECHNOLOGY (ITM-UPV) UNIVERSITY POLYTECHNIC OF \\ VALENCIA, SPAIN \\ ${ }^{2}$ PRODUCTION ENGINEERING AND PRINTING TECHNOLOGY DEPARTMENT, AKHBAR EL \\ YOM ACADEMY, GIZA, EGYPT \\ pramo@doctor.upv.es,anamma@upvnet.upv.es,abahel@doctor.upv.es,vamigo@mcm.upv.es
}

\begin{abstract}
$\mathrm{Ti}$ and its alloys are mostly used biomaterials due to its unique properties like (high corrosion resistance, low elastic modulus, high mechanical strength/ density, good biocompatibility etc.).Ti $\beta$ alloys based on the Ti-Mo alloy system shows much more interest for biomaterials researcher. Addition of $\mathrm{Zr}$ and small amount of $\mathrm{Fe}$ improves the $\beta$-phase stability and improving the properties of Ti-Mo alloy. These alloys produced by powder metallurgy (PM) using firstly elemental blend (EB) technique (600 MPa pressure) and then after Mechanical alloying technique (600 MPa and 900 $\mathrm{MPa}$ ).Mechanical alloying used mainly for improving mixing and better diffusion of elements. This paper describes the microstructural characterization and mechanical properties obtained by bending test, Archimedes test and ultrasonic test of Ti-Mo-Zr-Fe alloys made by elemental blend and mechanical alloying technique. The Mechanical alloying allows highly homogeneous composition and particle morphology. Bending strength is more in elemental blend in compare to mechanical alloying technique. Increasing of compaction pressure during mechanical alloying technique increases bending strength and decreases porosity. Mainly two phases appears on sintered sample name as $\alpha$-phase and $\beta$ - phase.
\end{abstract}


Mohan, P., Amigó Mata, A. and Amigó, V., 2016. Effects of Fe and Mo Content on the Microstructure and Mechanical Properties of Ti-Mo based alloys prepared by Elemental blend and Mechanical alloying technique. In Transactions of Powder Metallurgy Association of India (Vol. 42, No. 1, pp. 25-31). Powder Metallurgy Assoc. of India

\title{
EFFECT OF POWDER PROCESSING ON THE MICROSTRUCTURE AND MECHANICAL PROPERTIES OF TI-MO ALLOYS
}

\author{
P.Mohan ${ }^{I}$,A. Amigo ${ }^{I}$, Abou Bakr Elshalakany ${ }^{1,2}$, V.Amigo $^{l}$ \\ IINSTITUTE OF MATERIALS TECHNOLOGY (ITM-UPV) UNIVERSITY POLYTECHNIC OF \\ VALENCIA, SPAIN \\ ${ }^{2}$ PRODUCTION ENGINEERING AND PRINTING TECHNOLOGY DEPARTMENT, AKHBAR EL \\ YOM ACADEMY, GIZA, EGYPT \\ pramo@doctor.upv.es,anamma@upvnet.upv.es,abahel@doctor.upv.es,vamigo@mcm.upv.es
}

\begin{abstract}
$\mathrm{Ti}$ and its alloys are mostly used biomaterials due to its unique properties like (high corrosion resistance, low elastic modulus, high mechanical strength/ density, good biocompatibility etc.).Ti $\beta$ alloys based on the Ti-Mo alloy system shows much more interest for biomaterials researcher. Addition of $\mathrm{Zr}$ and small amount of $\mathrm{Fe}$ improves the $\beta$-phase stability and improving the properties of Ti-Mo alloy. These alloys produced by powder metallurgy (PM) using firstly elemental blend (EB) technique (600 MPa pressure) and then after Mechanical alloying technique (600 MPa and 900 $\mathrm{MPa}$ ).Mechanical alloying used mainly for improving mixing and better diffusion of elements. This paper describes the microstructural characterization and mechanical properties obtained by bending test, Archimedes test and ultrasonic test of Ti-Mo-Zr-Fe alloys made by elemental blend and mechanical alloying technique. The Mechanical alloying allows highly homogeneous composition and particle morphology. Bending strength is more in elemental blend in compare to mechanical alloying technique. Increasing of compaction pressure during mechanical alloying technique increases bending strength and decreases porosity. Mainly two phases appears on sintered sample name as $\alpha$-phase and $\beta$ - phase.
\end{abstract}

